\title{
AVALIAÇÃO POR MICROTOMOGRAFIA DE RAIO-X DO REPARO ÓSSEO EM OSTEOTOMIA COMPLETA DE TÍBIA DE RATOS APÓS TRATAMENTO COM ULTRASSOM DE BAIXA INTENSIDADE E LASER DE BAIXA POTÊNCIA
}

Tese de doutorado apresentada ao Programa de Pós - Graduação Interunidades Bioengenharia Escola de Engenharia de São Carlos / Faculdade de Medicina de Ribeirão Preto / Instituto de Química de São Carlos da Universidade de São Paulo como parte dos requisitos para a obtenção do título de Doutor (a) em Ciências.

Área de Concentração: Bioengenharia

Orientador: Prof. Dr. José Marcos Alves

\section{Versão Corrigida}

São Carlos 


\section{Programa de Pós-Graduação Interunidades em Bioengenharia EESC / FMRP / IQSC}

\section{Alessandra Rossi Paolillo}

Título: "Avaliação por microtomografia de raio-X do reparo ósseo em osteotomia completa após tratamento com ultrassom de baixa intensidade e laser de baixa potência".

\section{TESE APRESENTADA AO PROGRAMA DE PÓS-GRADUAÇÃO INTERUNIDADES BIOENGENHARIA - EESC/FMRP/IQSC DA UNIVERSIDADE DE SÃO PAULO PARA OBTENÇÃO DO TÍTULO DE DOUTOR EM CIÊNCIAS NA ÁREA DE BIOENGENHARIA.}

Aprovada em: $12,12,13$

Prof. Dr. José Marcos Alves (Orientador)

Resultado:

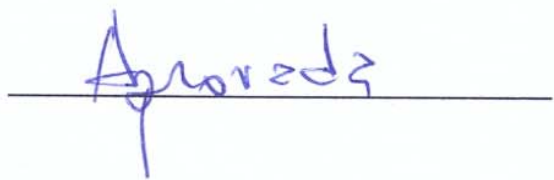

Prof. Dr. Rodrigo Bezerra de Menezes Reiff

Resultado: Anverale

Escola de Engenharia de São Caŕlos - USP

Assinatura:

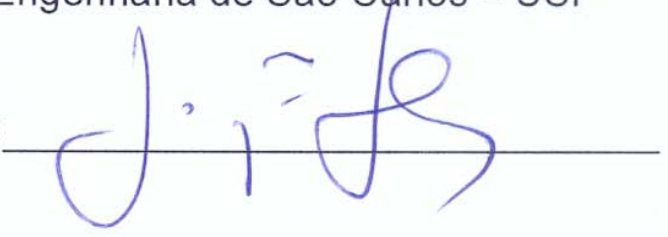

Universidade Federal de São Carlos - UFSCar

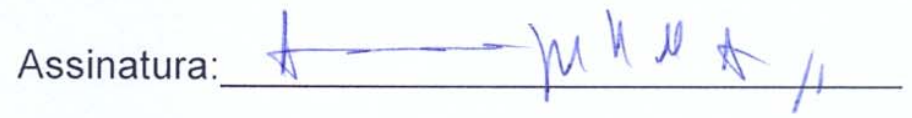

Escola de Engenharia de São Carlos - USP

Assinatura:

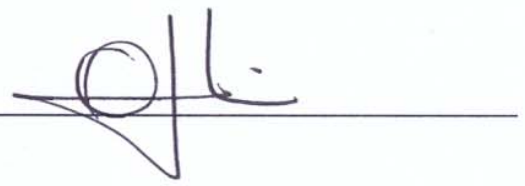

Instituto de Ciências Biomédicas - USP

Assinatura:

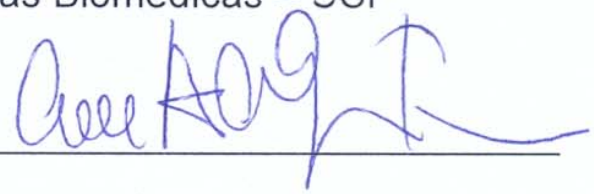

Faculdade de Medicina de São Paulo - USP

Assinatura:

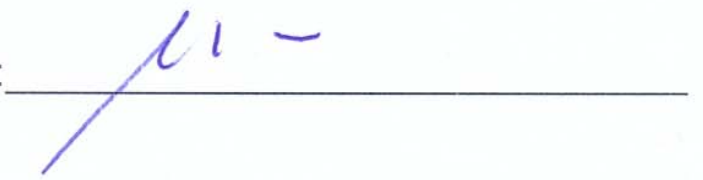

Homologado em: 1 


\title{
DEDICATÓRIA
}

Aos meus queridos filhos Lucas, Marina e Júlia.

Que esse trabalho seja mais um exemplo em suas vidas.

\author{
Exemplo de: \\ SUPERAÇÃO DE DIFICULDADES \\ FORÇA DE VONTADE \\ PERSEVERANÇA \\ DEDICAÇÃO \\ RESILIÊNCIA
}

Enfim, de ALEGRIA e ESPERANÇA...

Lembrando o que escreveu o poeta: se "A dor é inevitável. O sofrimento é opcional”...

Amo vocês!!! 


\section{AGRADECIMENTOS}

Aos meus pais Marta e Nicola pelo apoio, incentivo e afeto.

Aos meus filhos Lucas, Marina e Júlia pelo carinho, compreensão e paciência.

Ao Giovani pelo suporte, estímulo e companheirismo.

À minha irmã Fernanda pelo afeto, colaboração e importantes contribuições.

A toda minha família, aos que estão ao meu lado e torcem por mim e aos que partiram, antes da conclusão desse trabalho... Meu eterno agradecimento à querida Tia Rosa.

Ao PPGIB - USP, IFSC - USP e EESC - USP por propiciarem a realização desse trabalho.

Ao PPGIB - USP por disponibilizar a infraestrutura para a realização desse trabalho.

Ao Prof. Dr. José Marcos Alves do PPGIB - USP pela orientação, paciência e amizade durante o desenvolvimento desse trabalho.

Ao Prof. Dr. Vanderlei Salvador Bagnato do IFSC - USP pela co-orientação, apoio financeiro para a realização desse trabalho e amizade.

À Prof. ${ }^{a}$ Dr $^{\mathrm{a}}$ Janice Rodrigues Perussi, do IQSC - USP, e Dr. Orivaldo Lopes da Silva, do PPGIB - USP, pelos ensinamentos e conversas edificantes.

Ao Prof. Dr. Rodrigo Bezerra de Menezes Reiff, do Departamento de Medicina - UFSCar, pela realização da cirurgia experimental, análise cega do reparo ósseo e amizade.

Ao Dr. Phil Salmon cientista de aplicação da Bruker-MicroCT (Bélgica) pela colaboração na análise morfométrica microtomográfica por raio-x e sugestões para a conclusão desse trabalho.

À Prof. ${ }^{a}$ Dr $^{a}$. Consuelo Junqueira Rodrigues do Laboratório de Investigação do Sistema Músculo-Esquelético, Laboratório de Biomecânica, Instituto de Ortopedia e Traumatologia do Hospital das Clínicas da FM-USP pela análise histomorfométrica das amostras ósseas.

À Adriana Luísa Gonçalves de Almeida, técnica do Laboratório de Microscopia e Análise de Imagens, FORP - USP pelo escaneamento e reconstrução das imagens microtomográficas das amostras ósseas.

À ACECIL - Central de Esterilização Comércio e Indústria Ltda (Campinas - SP) que gentilmente realizou a esterilização a óxido de etileno dos fios de Kirschner e espaçadores para o procedimento experimental dessa pesquisa.

À Plasnova Tubos Louveira Ind. Com. Ltda (Louveira - SP) que gentilmente forneceu os tubos plásticos para confecção dos espaçadores utilizados no procedimento cirúrgico dessa pesquisa.

Ao Biotério da UFSCar pela disponibilização dos animais para o experimento. 
Ao biólogo Nélson Ferreira da Silva Júnior do PPGIB - USP pelo empenho durante o procedimento experimental dessa pesquisa.

Às secretárias Janete, Nathália e Juliana (PPGIB - USP) e Isabel, Benê e Cris (IFSC - USP) pelo pronto atendimento, carinho e atenção nas questões administrativas.

Ao Alessandro Márcio Hakme da Silva, doutorando do PPGIB-USP, pela colaboração no processamento das reconstruções microtomógraficas.

À Maria Angélica Zucareli Sousa, doutoranda em Engenharia Elétrica, LAPIMO, Escola de Engenharia de São Carlos - USP, pelo escaneamento dos filmes de raio-X.

À Rosana Alice Fávero pelos ensinamentos da língua inglesa e pela amizade.

Aos meus amigos e todos aqueles que de alguma forma participaram dessa etapa da minha vida.

Muito obrigada hoje e sempre! 


\section{RESUMO}

PAOLILlO, A. R. Avaliação por Microtomografia de Raio-X do Reparo Ósseo em Osteotomia Completa de Tíbia de Ratos Após Tratamento com Ultrassom de Baixa Intensidade e Laser de Baixa Potência. 2013. 129p. Tese (Doutorado) - Programa de PósGraduação Interunidades Bioengenharia - Escola de Engenharia de São Carlos / Faculdade de Medicina de Ribeirão Preto/ Instituto de Química de São Carlos, Universidade de São Paulo, São Carlos, 2013.

As fraturas são consideradas um dos maiores problemas de saúde pública pelo custo e morbidade a elas associados. O objetivo deste estudo foi investigar os efeitos do ultrassom de baixa intensidade (LIPUS) e do laser de baixa potência (LLLT) sobre o reparo ósseo de tíbia de ratos (Wistar) utilizando a microtomografia por raio-x $(\mu \mathrm{CT})$ e a análise histomorfométrica. Uma osteotomia total no terço médio foi fixada com fio de Kirschner $(0,89 \mathrm{~mm})$ e utilizado um espaçador polimérico de $2 \mathrm{~mm}$ de espessura e $1 \mathrm{~mm}$ de diâmetro entre os fragmentos proximal e distal para induzir retardo de consolidação da fratura. Foram utilizados 24 animais separados aleatoriamente em 4 grupos experimentais: Grupo Controle: sem tratamento do retardo da consolidação $(n=5)$; Grupo Laser: tratamento da fratura com laser $(n=6)$; Grupo LIPUS: tratamento da fratura com LIPUS $(n=7)$ e; Grupo LIPUS + Laser: tratamento da fratura com LIPUS e Laser $(n=7)$. Os tratamentos com LIPUS e/ou Laser foram iniciados após 5 semanas da cirurgia e realizados durante 5 dias consecutivos de tratamento, seguidos por 2 dias sem serem tratados até totalizarem 12 sessões terapêuticas. Os parâmetros de irradiação laser foram: $808 \mathrm{~nm} ; 100 \mathrm{~mW} ; 2500 \mathrm{~mW} / \mathrm{cm}^{2}, 125 \mathrm{~J} / \mathrm{cm}^{2}$ durante 50 segundos. Os parâmetros do LIPUS foram: 1,5 MHz, ciclo de trabalho 1:4, intensidade de 30 $\mathrm{mW} / \mathrm{cm}^{2}, 20$ minutos por sessão. Quando as duas técnicas foram associadas, o laser foi aplicado perpendicularmente ao LIPUS no décimo minuto de aplicação do LIPUS. Radiografias da tíbia foram feitas para acompanhar a evolução da fratura após a cirurgia, antes dos tratamentos e antes da eutanásia. Após a eutanásia foram realizadas avaliações microtomográficas por raio-x e histomorfométricas para análise do reparo ósseo. $\mathrm{Na}$ análise microtomográfica do reparo ósseo o tecido neoformado de reparo (calo ósseo) e o tecido normal não foram isolados. Na análise estatística foi utilizada a ANOVA one-way com posthoc de Tukey. Não foi constatada diferença significativa para maioria das variáveis, exceto para o fator padrão trabecular (Tb.Pf) no grupo LIPUS+Laser comparado aos grupos LIPUS $(\mathrm{p}=0.02)$, Laser $(\mathrm{p}=0.02)$ e Controle $(\mathrm{p}=0.01)$, para a conectividade (Conn) no grupo Laser comparada ao grupo Controle $(\mathrm{p}=0.04)$ e para a densidade de conectividade (D.Conn) no grupo LIPUS+Laser comparado ao grupo Controle $(\mathrm{p}=0.04)$. As imagens histológicas mostram maior quantidade de tecido esponjoso no grupo LIPUS+Laser. Parâmetros morfométricos e histomorfométricos não revelaram um avanço do reparo ósseo na comparação entre os grupos com tratamento em relação ao grupo controle provavelmente devido a não reabsorção do espaçador polimérico pelo organismo dos animais. A $\mu$ CT é uma técnica de grande potencial que permite análises qualitativas e quantitativas e reconstruçoes $2 \mathrm{D}$ e $3 \mathrm{D}$.

Palavras-chaves: Osteotomia Completa. Consolidação Óssea. Microtomografia por Raio-x. Ultrassom. Laser. 


\begin{abstract}
PAOLILLO, A. R. Assessment of bone repair by x-ray microtomography in complete Tiba Rats osteotomy After Low-Intensity Pulsed Ultrasound and Low-Level Laser Therapy. 2013. 129p. Tese (Doutorado) - Programa de Pós-Graduação Interunidades Bioengenharia - Escola de Engenharia de São Carlos / Faculdade de Medicina de Ribeirão Preto / Instituto de Química de São Carlos, Universidade de São Paulo, São Carlos, 2013.

Bone fractures are important public health problems due to the morbidity and high cost related to them. The aim of this study was to evaluate the effects of low pulsed intensity ultrasound (LIPUS) and infrared low level laser therapy (LLLT) in the bone repair of a transverse rat tibia osteotomy with assessement by x-ray microtomography $(\mu \mathrm{CT})$ and histomorphometry. An easily implemented transverse osteotomy with a Kirchner wire and $2 \mathrm{~mm}$ width polymeric spacer beads established a delayed union in the fracture. Twenty four rats were divided into four experimental groups: Control Group - untreated; Laser Group treated with infrared LLLT; LIPUS Group - treated with low intensity pulsed ultrasound; LIPUS+Laser Group - treated with low intensity pulsed ultrasound and infrared LLLT. The treatments with infrared LLLT $\left(808 \mathrm{~nm}, 100 \mathrm{~mW}, 2500 \mathrm{~mW} / \mathrm{cm}^{2}, 125 \mathrm{~J} / \mathrm{cm}^{2}, 50\right.$ seconds $)$ and LIPUS (1,5 MHz, 1:4 duty cicle, $30 \mathrm{~mW} / \mathrm{cm}^{2}, 20$ minutes) started 5 weeks after the surgery following a sequence of 5 days on and 2 days off until 12 sessions were reached. When LLLT and LIPUS therapies were used simultaneously there was a $90^{\circ}$ angle between the laser and the ultrasound beams. The surgical technique and the bone repair were assessed by $\mathrm{x}$-ray radiography. One-way analysis of variance (one-way ANOVA) and Tukey post-hoc were used for statistical analysis. The normal bone and the callus were kept together in the $\mu \mathrm{CT}$ analysis. There was no significant difference between treatments results except for the parameters trabecular pattern factor - Tb.Pf [US+Laser group x LIPUS group $(\mathrm{p}=0.02)$; US+Laser group $x$ Laser group $(p=0.02)$ and US+Laser group $x$ Control group $(p=0.01)$ ], connectivity - Conn [Laser group x Control group $(\mathrm{p}=0.04)$ ] and connectivity density D.Conn [US+Laser group x Control group $(\mathrm{p}=0.04)]$. The histology showed greater amount of spongeous bone in the LIPUS+Laser group. The morphometric and histomorphometric assessments didn't show a faster bone repair when treated groups were compared against the control one. The non absorption of the polymeric spacer bead is probably the reason of these findings. The $\mu \mathrm{CT}$ is a powerful technique that allows 2D and 3D quantitative analysis and reconstructions.
\end{abstract}

Keywords: Complete Osteotomy. Fracture Healing. X-ray Microtomography. Ultrasound. Laser. 


\section{LISTA DE FIGURAS}

Figura 1 - Fototerapia de Finsen

Figura 2 - Ultrassom terapêutico na década de 1940 para os tratamentos de úlcera gástrica à esquerda e de artrite reumatóide à direita

Figura 3 - Reflexão e refração do ultrassom 22

Figura 4 - $\quad$ Balança de força de radiação 25

Figura 5 - Dosímetro de US comercial $\quad 25$

Figura 6 - Sinal elétrico aplicado ao transdutor de ultrassom $\quad 26$

Figura 7 - Principais estruturas que compõem o tecido ósseo 27

Figura 8 - Componentes de um microtomógrafo $\quad 31$

Figura 9 - Etapas da microtomografia computadorizada por raios-x $\quad 31$

Figura 10 - Atenuação de um feixe de fótons por uma amostra 32

Figura 11 - Cilindros com diâmetros de 2-4mm, 8-16mm e 32mm e com concentrações de 0,25 g.cm³ e 0,75 g.cm ${ }^{3}$ de CaHA da Bruker Micro CT

Figura 12 - O aumento do diâmetro de um phantom de CaHA diminui a medida do coeficiente de atenuação

Figura 13 - Procedimento de hidratação de amostras ósseas para escaneamento 34

Figura 14 - Sistemas fotoacústicos para imagens médicas 36

Figura 15 - Tecidos envolvidos no reparo de uma fratura óssea $\quad 40$

Figura 16 - Estrutura simplesmente conectada e multiplamente conectada $\quad 47$

Figura 17 - Ilustração de um corpo convexo e não-convexo 48

Figura 18 - Representação do conceito do fator padrão de osso trabecular 49

Figura 19 - Procedimento de dilatação em uma estrutura convexa e côncava 49

Figura 20 - Estruturas fractais $\quad 50$

Figura 21 - Técnica de contagem de quadrados para a medida da dimensão fractal 51 
Figura 22 - Isolamento do calo ósseo em fratura de fêmur utilizando-se $\mu \mathrm{CT}$ e resolução de $12 \mu \mathrm{m}$

Figura 23 - Isolamento do calo ósseo em fratura de fêmur utilizando-se $\mu \mathrm{CT}$ e resolução de $28 \mu \mathrm{m}$

Figura 24 - Imagem parcial do Biotério

Figura 25 - Imagens pós-cirúrgicas (A) e radiográficas (B) de tibias de rato

Figura 26 - Osteotomia completa

Figura 27 - Introdução do fio de Kirschner e do espaçador polimérico

Figura 28 - Espaçadores transparentes e o de Kirschner na embalagem após 58 esterilização por óxido de etileno

Figura 29 - Linha do tempo $\quad 58$

Figura 30 - Procedimento laboratorial do registro das imagens por raio- $\mathrm{x} \quad 58$

Figura 31 - Tratamento com Laser $\quad 61$

Figura 32 - Tratamento com LIPUS $\quad 62$

Figura 33 - Tratamento com associação de Laser e LIPUS $\quad 62$

Figura 34 - Microtomógrafo com compartimento da amostra aberto e fechado 63 durante escaneamento das amostras ósseas

Figura 35 - Phantoms de CaHA com diâmetro de $4 \mathrm{~mm}$ e concentração de $0,25 \mathrm{~g} / \mathrm{cm}^{3} \quad 64$ e $0,75 \mathrm{~g} / \mathrm{cm}^{3}$

Figura 36 - ROI circular na seção transversal do phantom com concentração de 64 $0,75 \mathrm{~g} / \mathrm{cm}^{3}$

Figura 37 - Escolha das seções transversais no phantom com concentração de 64 $0,75 \mathrm{~g} / \mathrm{cm}^{3}$

Figura 38 - Histogramas de densidade de uma seção da VOI

Figura 39 - Determinação da equação da BMD em função dos valores médios dos 65 coeficientes de atenuação

Figura 40 - Seleção da ROI para medida da TMD no osso trabecular 66

Figura 41 - ROI contendo osso trabecular na VOI de interesse 67 
Figura 42 - Binarização para seguimentação do osso trabecular

Figura 43 - Seleção da ROI para medida da TMD no osso cortical 68

Figura 44 - Binarização para seguimentação do osso cortical $\quad 69$

Figura 45 - uma amostra

Procedimento de abrir os arquivos de reconstrução microtomográfica de 70

Figura 46 - Procedimento de escolha da seção transversal superior da VOI

Figura 47 - Procedimento de escolha da seção transversal inferior da VOI 71

$\begin{array}{lll}\text { Figura } 48 \text { - } & \text { Definição da VOI da amostra } & 71\end{array}$

Figura 49 - Escolha da ROI da VOI da amostra 72

$\begin{array}{lll}\text { Figura 50- } & \text { Carregamento da task list } & 72\end{array}$

Figura 51 - Aplicação de thresholding para seleção do fio de Kirschner 73

Figura 52 - Procedimento de dilatação das imagens do fio de Kirschner 73

Figura 53 - Remoção das imagens dilatadas do fio de Kischner $\quad 74$

Figura 54 - Visualização da eliminação do fio de Kirschner em uma das seções transversais da amostra

Figura 55 - Thresholding das seções transversais sem a presença do fio de Kirschner 75

Figura 56 - Definição da VOI contendo as seções digitalizadas 75

Figura 57 - Remoção de pixels não pertencentes às seções transversais e localizados $\begin{array}{ll}\text { na periferia das mesmas } & 76\end{array}$

Figura 58 - Remoção dos poros não pertencentes às seções transversais $\quad 76$

Figura 59 - Seleção do contorno das seções transversais $\quad 77$

Figura 60 - Refinamento do contorno da ROI de cada seção transversal $\quad 77$

Figura 61 - Escolha dos parâmetros morfométricos a serem calculados $\quad 78$

Figura 62 - Separação do tecido ósseo neoformado do tecido normal com níveis de cinza de $32-70$

Figura 63 - Separação do tecido ósseo neoformado do tecido normal com níveis de cinza de $24-27$

Figura 64 - Corte em sentido coronal da amostra evidenciando a presença do 
espaçador

Figura 65 - Fator Padrão Trabecular no calo ósseo obtido por microtomografia

Figura 66 - Densidade de Conectividade no calo ósseo obtido por microtomografia

Figura 67 - Conectividade no calo ósseo obtido por microtomografia

Figura 68 - Área fibrótica no calo ósseo obtida por histomorfometria

Figura 69 - Calo ósseo do grupo CONTROLE

Figura 70 - Calo ósseo do grupo LASER

Figura 71 - Calo ósseo do grupo LIPUS

Figura 72 - Calo ósseo do grupo LIPUS+Laser 


\section{LISTA DE TABELAS}

Tabela 1 - Tipos de Laser mais utilizados na fototerapia

Tabela 2 - Valores de impedância acústica

Tabela 3 - Coeficientes de atenuação de tecidos biológicos

Tabela 4 - Controle radiográfico

Tabela 5 - $\quad$ Avaliação Radiográfica Cega

Tabela 6 - Grupo Experimental Controle

Tabela 7 - Grupo Experimental Laser

Tabela 8 - Grupo Experimental LIPUS

Tabela 9 - Grupo Experimental LIPUS e Laser

Tabela 10 - Médias e desvios padrão dos parâmetros ósseos morfométricos e topológicos obtidos por microtomograa por raio-X

Tabela 11 - Médias e desvios padrão dos parâmetros ósseos obtidos por histomorfometria 


\section{LISTA DE ABREVIATURAS E SIGLAS}

\begin{tabular}{ll}
$\mu$ CT & Microtomografia computadorizada \\
ROI & Região de interesse do objeto \\
VOI & Volume de interesse do objeto \\
2D & Bidimensional \\
3D & Tridimensional \\
CT & Tomografia computadorizada \\
BMD & Densidade mineral óssea \\
TV & Volume do tecido \\
BV & Volume ósseo \\
BV/TV & Porcentagem de volume ósseo \\
BS/BV & Fração superfície óssea/volume ósseo \\
Conn & Conectividade de Euler \\
Eu.N & Número de Euler \\
Conn. D & Conectividade de Euler \\
Tb.Pf & Fator padrão trabecular \\
FD & Dimensão fractal \\
NADH & Nicotinamida adenina dinucleotídio \\
ATP & Adenosina trifosfsto \\
DNA & Ácido desoxirribonucleico \\
RNA & Ácido ribonucleico \\
US & Ultrassom \\
SGPs & Potenciais Gerados por Deformação \\
SATA & Space average time average \\
IL & Interleucina \\
TNF & Fator de Necrose Tumoral \\
CSF-GM & Fator estimulante de colônia de granulócitos-macrófagos \\
CaHA & Hidroxiapatita de cálcio \\
TMD & Densidade Mineral do Tecido \\
PVC & Policloreto de Vinila \\
LIPUS & Low Intensity Pulsed Ultrasound \\
LLLT & Low Level Laser Therapy \\
LASER & Light Amplification by Stimulated Emission of Radiation \\
BMP & Proteína Óssea Morfogenética \\
\hline
\end{tabular}




\section{LISTA DE SÍMBOLOS}

$\begin{array}{ll}\mathbf{m m}^{\mathbf{3}} & \text { Milímetro cúbico } \\ \mathbf{M H z} & \text { Mega Hertz } \\ \mathbf{d B} & \text { Decibel } \\ \mathbf{c m} & \text { Centímetro } \\ \mathbf{\mu m} & \text { Micrômetro } \\ \mathbf{n m} & \text { Nanômetro } \\ \mathbf{W} & \text { Watt } \\ \mathbf{m W} & \text { Miliwatt } \\ \mathbf{A l} & \text { Alumínio } \\ \mathbf{C u} & \text { Cobre } \\ { }^{\circ} \mathbf{C} & \text { Graus Celsius }\end{array}$




\section{SUMÁRIO}

1 INTRODUÇÃ

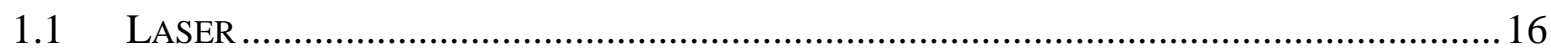

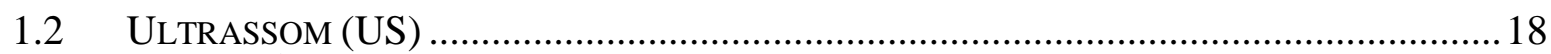

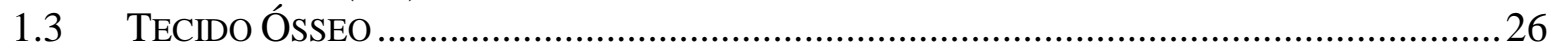

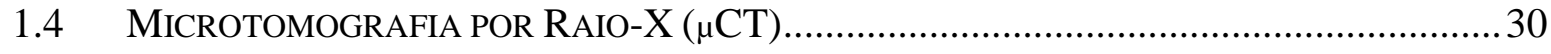

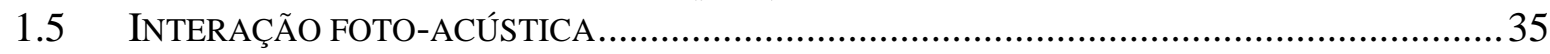

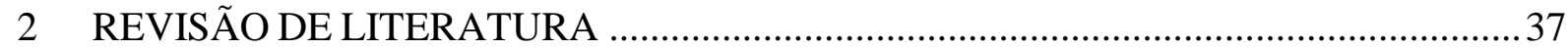

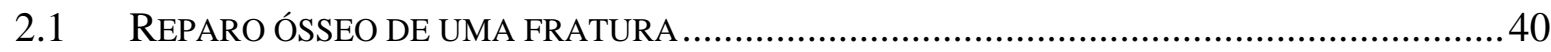

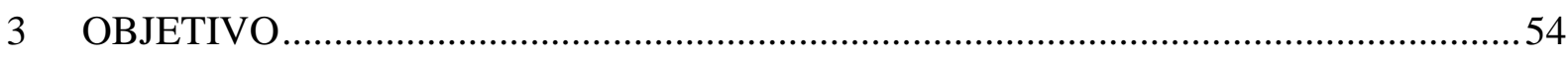

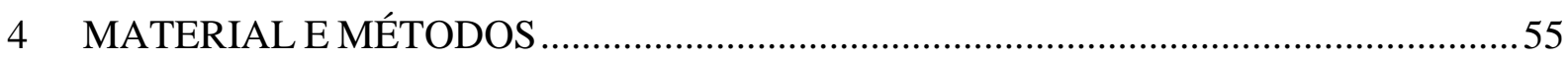

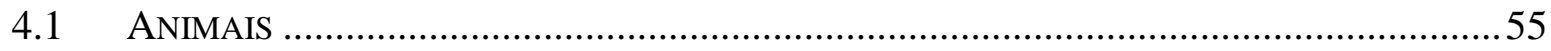

4.2 PROCEDIMENTO CIRÚRGICO: INDUÇÃO DE RETARDO DE CONSOLIDAÇÃO ....................56

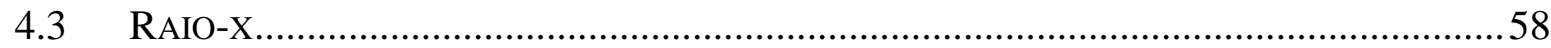

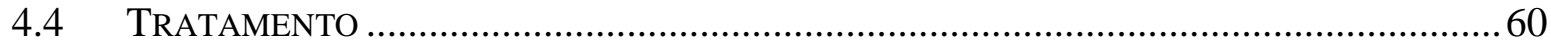

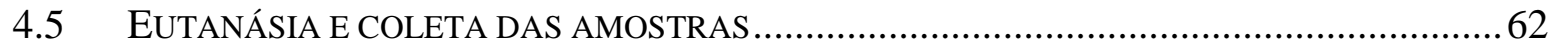

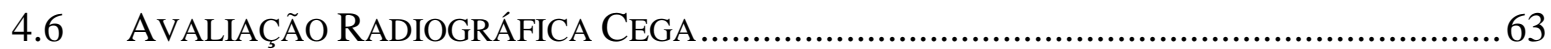

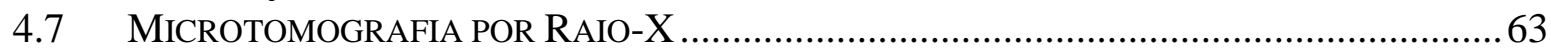

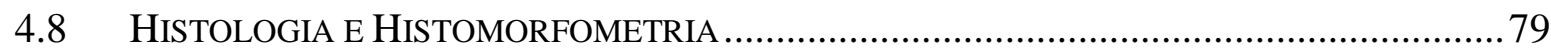

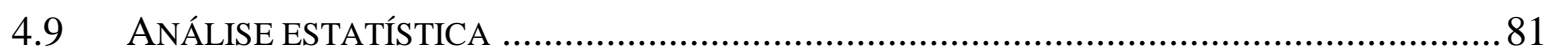

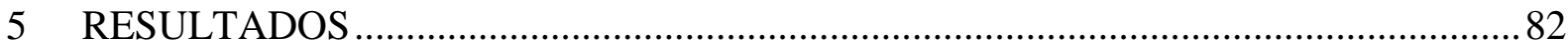

5.1 AVAliação Radiográfica Cega do Reparo ÓSSEO POR Microtomografia

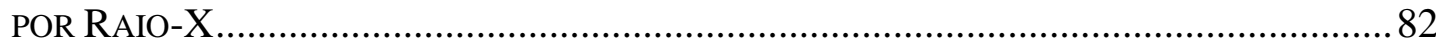

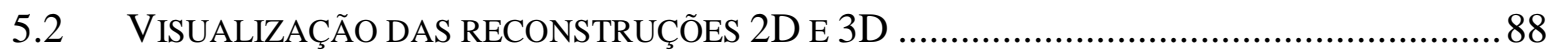

5.3 QUANTIFICAÇÃ̃ DO CALO ÓSSEO ….......................................................................... 96

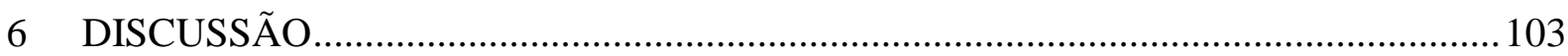

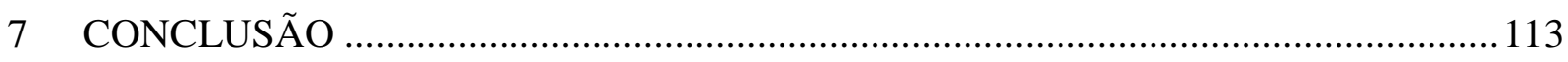

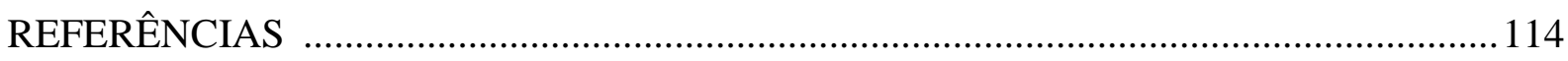

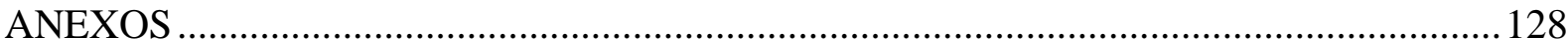




\section{INTRODUÇÃO}

As fraturas têm impacto econômico e social sendo um dos maiores problemas do sistema de saúde público e privado, devido aos elevados custos com o tratamento e alto índice de morbidade/mortalidade (KEEN, 2007). No Brasil, estudos epidemiológicos indicam elevada frequência de fratura e revelam uma maior incidência nos ossos longos, como a tíbia e estão relacionadas aos acidentes de trânsito. Outro aspecto é a relação de uma morte a cada 11 indivíduos com sequela permanente e 38 internações hospitalares a cada 380 atendimentos nas emergências (CARDOZO et al., 2013).

Nas últimas décadas teve início um processo de inversão da pirâmide etária na característica populacional. Essa mudança demográfica vem ocorrendo em todo o mundo e demonstra que o ritmo de crescimento do número de idosos vem aumentando consideravelmente. Os idosos, em especial as mulheres na pós-menopausa, podem apresentar osteoporose que é uma doença sistêmica, caracterizada pela diminuição da massa óssea e deterioração da arquitetura do tecido ósseo, resultando em fragilidade e risco de fraturas, com maior incidência no quadril, vértebras e antebraço.

As fraturas são o principal exemplo de lesão do tecido ósseo e podem ser classificadas em: i) primária, que ocorre em consequência imediata ao trauma e ii) secundária, devido a doenças prévias (KUMAR, 2007). As fraturas ósseas requerem estabilidade para consolidarem e as hastes intramedulares, placas, pinos e fixadores externos são exemplos de dispositivos que proporcionam essa estabilidade à fratura.

O reparo ósseo consiste em um desafio, tanto para a medicina quanto odontologia, que buscam nos avanços tecnológicos uma alternativa para reparação de fraturas e crescimento ósseo, principalmente em complexos quadros clínicos, com atraso ou ausência de consolidação da fratura.

As pesquisas enfatizam a consolidação óssea no que se refere à diminuição do tempo de consolidação, fato que ainda é um desafio (CROCI et al., 2003). Neste contexto, as áreas de pesquisas relacionadas à Bioengenharia vêm crescendo significativamente na busca de soluções que facilitem a regeneração óssea em fraturas ou em casos de falhas ósseas decorrentes de não-uniões e neoplasias. A implementação de terapias alternativas que possam auxiliar no reparo de fraturas, estimulando ou acelerando o crescimento ósseo, são importantes por minimizar o tempo e custo do tratamento, o que favorece o retorno precoce da funcionalidade do membro comprometido. 


\subsection{Laser}

Desde tempos remotos na Grécia Antiga, Egito e China, a exposição ao sol era benéfica à saúde. Apolo, o "deus da luz" ficou com as funções de Hélios (deus do sol) e eliminou o culto a este deus (BAGNATO, 2008b). Com a luz do sol, Apolo garantia as colheitas agrícolas, a saúde do homem e tirava a civilização das trevas. O fogo que transmite luz e calor também era fundamental para o homem.

Os estudos com luz e cor iniciaram-se em torno de 1670, com Isaac Newton. Ele investigou a decomposição da luz solar ao passar por um prisma e concluiu que a luz branca é uma mistura de diferentes tipos de "raios luminosos", refratados em ângulos ligeiramente diferentes, cada um produzindo uma cor espectral diferente, ou seja, diferentes comprimentos de onda ou frequência (ASSIS, 2002; BAGNATO, 2008a).

Em 1800, Willian Herschell colocou um termômetro de mercúrio no espectro obtido por um prisma de cristal com a finalidade de medir o calor emitido por cada cor. Descobriu que o calor era mais forte ao lado do vermelho do espectro, observando que ali não havia luz. Assim, a região infravermelha do espectro foi descoberta.

Em torno de 1870, dentre várias invenções, Thomas Edison desenvolveu a lâmpada elétrica incandescente. Em 1903, Nielsen Ryberg Finsen recebeu o prêmio Nobel de fisiologia e medicina por realizar a fototerapia com lâmpadas (BAROLET, 2008), no hospital de Londres, para tratar lúpus vulgaris (mycobacterium tuberculosis), que são lesões dolorosas na pele (Figura 1).

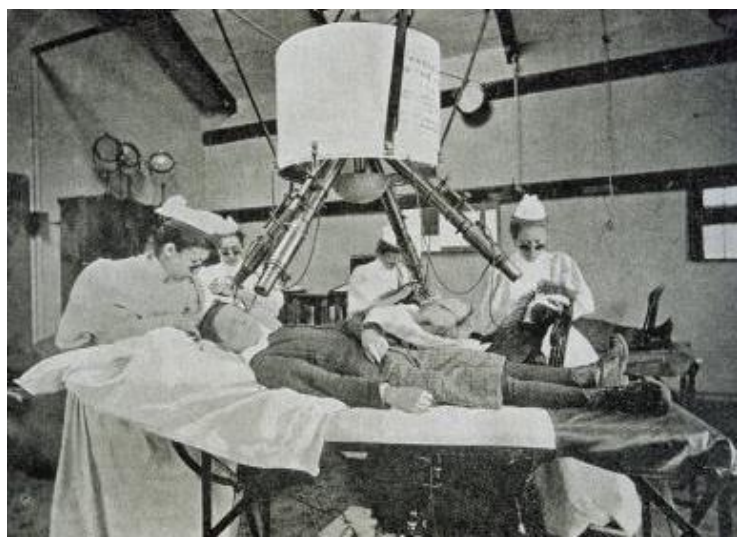

Figura 1- Fototerapia de Finsen. Fonte: http://www.historiadelamedicina.org/finsen.html.

Em 1921, Albert Einsten recebeu o prêmio Nobel da Física por propor a teoria do efeito fotoelétrico, pelo conceito de "emissão estimulada" para a descoberta do laser (SILVA; SILVA \& CARDOSO, 2011). 
A palavra Laser é um acrônimo para amplificação da luz por emissão estimulada de radiação. A luz emitida do laser é obtida a partir de um mecanismo especial, no qual um meio ativo com átomos no estado fundamental se tornam excitados na presença, por exemplo, de descarga elétrica ou luminosa. A emissão espontânea de um fóton por um desses átomos adiciona mais luz à porção já existente. Esses fótons se refletem nos espelhos da cavidade, voltando para a amostra e provocando mais emissão estimulada e uma porção dessa luz emerge do sistema, constituindo o feixe da luz laser. Dependendo do meio ativo serão obtidos diferentes comprimentos de onda, na região do espectro visível e invisível (BAGNATO 2008a; BAGNATO 2008b).

Com o avanço tecnológico, diversos dispositivos de laser foram desenvolvidos, alguns exemplos utilizados para fototerapia são mostrados na tabela 1.

\begin{tabular}{lll}
\hline \multicolumn{3}{c}{ Tabela 1 - Tipos de laser mais utilizados na fototerapia. } \\
\hline Laser & Comprimento de onda & Cor \\
Gálio e Neônio (He-Ne) & $632.8 \mathrm{~nm}$ & Vermelho \\
Arseneto de Helio-Neôneo (As-Ne-He) & $630-685 \mathrm{~nm}$ & Vermelho \\
Arseneto de Gálio (As-Ga) & $780-870 \mathrm{~nm}$ & Infravermelho \\
\hline
\end{tabular}

O laser se destaca das outras fontes de luz devido à colimação e coerência. A colimação permite concentrar o feixe de luz em um ponto focal, mantendo a potência óptica ao longo de distâncias consideráveis e uma maior concentração de energia. A coerência da luz denota uma das propriedades específicas da radiação laser, que está intimamente relacionada com os mecanismos de emissão estimulada. Quando um feixe de luz coerente e contínuo é transmitido ou espalhado por uma superfície com rugosidades da ordem do comprimento de onda incidente ocorre a formação de uma estrutura granular no espaço livre, denominada Speckle. A coerência é descrita por meio da capacidade de determinação da interferência das cristas das ondas eletromagnéticas quando interagem com uma segunda emissão laser no mesmo comprimento de onda (CORAZZA, 2005), principalmente devido à formação de Speckle. Quando iluminadas por luz coerente, a onda refletida destas superfícies é constituída por contribuições de muitas áreas independentes de espalhamento (HODE et al., 2009). De acordo com o princípio de Hugens-Fresnel, quando um feixe de luz incide uma superfície, cada ponto desta age como um emissor de pequenas ondas secundárias, o que pode resultar em vantagens para interação luz - tecido biológico. 
A absorção e o espalhamento da luz no tecido biológico são dependentes do comprimento de onda e dos cromóforos no tecido, que são biomoléculas da mitocôndria que absorvem luz. A hemoglobina e a melanina tem alta absorção nas bandas com comprimentos de onda menores que $600 \mathrm{~nm}$, enquanto a água começa a absorver significativamente em comprimentos de onda menor que $1150 \mathrm{~nm}$. Assim, a janela óptica terapêutica é primeiramente limitada pela absorção, devido ao sangue em menores comprimentos de onda e à água em maiores comprimentos de onda (BAROLET, 2008). Então, o infravermelho tem menor absorção e maior penetração comparada à luz visível. A região do infravermelho de 700 a 900nm está dentro das maiores aplicabilidades terapêuticas. A ativação celular ocorre através da absorção da luz por fotoaceptores, como a enzima NADH desidrogenase e citocromo $\mathrm{C}$ oxidase, que acelaram o transporte de elétrons na cadeia respiratória da mitocôndria e do citocromo C para oxigênio molecular. Estas modificações metabólicas possibilitam diversos efeitos terapêuticos, como o aumento da síntese de ATP, alterações nas expressões de DNA/RNA e regeneração tecidual, como o osso, músculo, pele e nervos (PAOLILLO et al., 2011). Ainda, a fotobioestimulação gera proliferação de fibroblastos, deposição de colágeno e aumento dos vasos sanguíneos com consequente aumento do suprimento de oxigênio e nutrientes ao novo tecido, o que favorece o aumento da taxa metabólica e da atividade mitótica celular (CORAZZA et al., 2005).

Em relação ao efeito analgésico, a fototerapia pode induzir ao alívio da dor pela modulação da nocicepção (CHOW; DAVID \& ARMATI, 2007; VINCK et al., 2005), bem como pelo aumento da produção de serotonina (CEYLAN; HIZMETLE \& SILIG, 2004), betaendorfina (HAGIWARA et al., 2007) e de antioxidantes com redução de mediadores inflamatórios (FILLIPIN et al., 2005). Ainda, a modulação da transmissão sináptica gera efeitos de relaxamento muscular (CASTANO et al., 2007).

\subsection{Ultrassom (US)}

Com a seleção natural das espécies, o ser humano passa a ter a capacidade de ouvir para aumentar a sobrevivência (SEYFARTH \& CHENEY, 2003). Muitos animais se comunicam por meio dos sons, além de poderem adquirir informações do ambiente ao seu redor (RUNDUS \& HART, 2002), como no caso dos golfinhos e morcegos, que possuem órgãos especiais para produzir e detectar os sons através das cordas vocais e ouvidos. A 
música faz parte da vida dos homens desde a época da Pré-história através da imitação dos sons da natureza (HEWES, 1973).

Em 1826, Jean-Daniel Colladon, um físico suíço, usou com sucesso um sino debaixo d'água para determinar a velocidade do som nas águas do Lago de Genebra. Na década de 1800, os físicos estudaram os princípios das vibrações sonoras, como a propagação, transmissão e refração das ondas. Entre eles estava Lord Rayleigh, da Inglaterra, que elaborou o famoso tratado "Teoria do Som", publicado em 1877 que descreveu a onda sonora como uma equação matemática, formando a base dos futuros trabalhos práticos em acústica (NEWMAN \& ROZYCKI, 1998).

A história do US remete-se ao estudo de Lazzaro Spallanzini em 1794, que demonstrou a capacidade dos morcegos em orientarem-se mais pela audição comparado a visão para localizar obstáculos e presas (WOO, 2012). O sistema de orientação por som é denominado de ecolocalização ou biosonar, caracterizado pela emissão de onda mecânica e reflexão em forma de eco com menor frequência.

Em 1880, Jacques e Pierre Curie descreveram as características físicas de alguns cristais (piezoeletricidade), contribuindo para o desenvolvimento do US, que foi impulsionado pelos objetivos militares e industriais. Neste contexto, sistemas de sonar submarino foram desenvolvidos com o propósito de navegação subaquática por submarinos na I Guerra Mundial, enquanto, as aplicações médicas ocorreram após a II Guerra Mundial, em torno de 1946, com o desenvolvimento de um dispositivo de US para diagnóstico por imagens médicas, por exemplo, no diagnóstico de tumor cerebral (NEWMAN \& ROZYCKI, 1998; WOO, 2012).

Ainda, sobre o US terapêutico (Figura 2), em 1917, Langevin (França) observou a morte de peixes durante o desenvolvimento de um sonar. Alguns anos depois, nos Estados Unidos (EUA) em 1926 e 1927, Woods e Loomis investigaram o efeito letal do US sobre as células, tecidos, peixes e rãs. Na Alemanha, em 1938, Ziess investigou os efeitos do ultrassom no olho. Em especial, Lynn e colaboradores foram nomeados os inventores do US terapêutico. Eles desenvolveram e testaram um US de alta potência focado e identificaram uma lesão tecidual sem gerar danos na respectiva região. Na década de 1940, Wall e colaboradores nos EUA; em 1950, Fry e Frite nos EUA; e em 1960, Oka et al. no Japão, desenvolveram um ultrassom focado para aplicação in vivo no sistema nervoso central. Fry e colaboradores iniciaram os estudos clínicos em 1956 e, simultaneamente, na Rússia, Burov e Andreevskaya no laboratório de estruturas anisotrópica, da Academia de Ciências da URSS 
testaram o US desfocado, com intensidade um pouco menor, em tumores e obtiveram maior efeito imunológico. A partir destes trabalhos pioneiros, o US foi aplicado em diversos tratamentos (BAILEY et al. 2003).
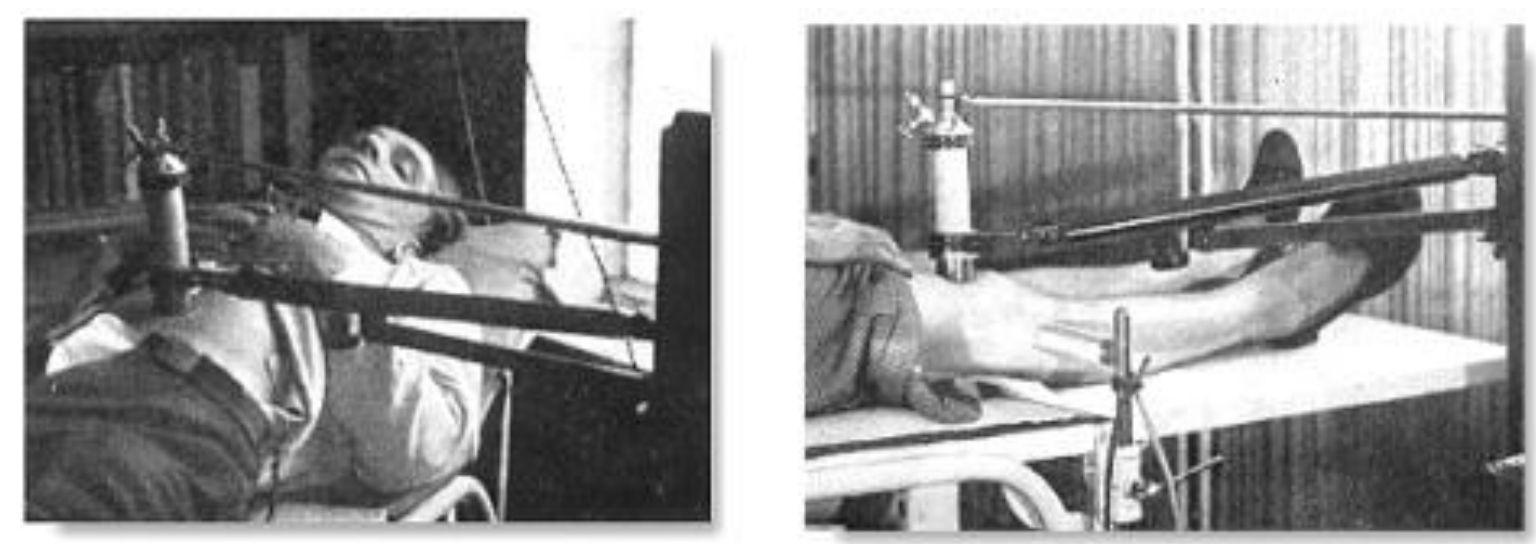

Figura 2 - Ultrassom terapêutico na década de 1940 para os tratamentos de úlcera gástrica à esquerda e de artrite reumatóide à direita. Fonte: http://www.ob-ultrasound.net/history1.html.

O US é uma forma de onda mecânica (acústica), na qual a energia é transmitida por vibrações das moléculas através do meio sólido, líquido e gasoso por onde a onda atravessa, com absorção da energia mecânica pelos tecidos corpóreos (ALLEN, 2006). Assim, a energia vibracional é transformada em energia molecular.

Quando o US terapêutico é aplicado para efeitos térmicos, os efeitos não térmicos também podem acontecer e vice-versa.

O US no modo contínuo produz efeito térmico predominante devido a absorção de energia e sua transformação em calor. Quanto maior a frequência do US maior a absorção. Ainda, tecidos com maior conteúdo proteico absorvem mais energia comparado, por exemplo, à gordura e à água. Então, frequências mais baixas, em torno de 1,0 MHz, penetram profundamente nos tecidos, por exemplo, musculares e ósseos. Por outro lado, 3,0 MHz são utilizados para absorção em profundidades menores, como na pele (HAAR, 1999).

Diversos são os efeitos terapêuticos do US, entre eles o aumento da vascularização, da atividade enzimática e da síntese de colágeno, bem como a aceleração do processo inflamatório para a reparação tecidual, no caso da pele, músculo, cartilagem e osso. Outros efeitos do US são o aumento da velocidade de condução neural e do limiar nociceptivo que contribuem para o tratamento da dor (ALLEN, 2006). O US também altera a contratilidade muscular, com redução de espasmos, além de gerar estímulo oesteogênico por meio dos potenciais gerados por deformação (SGPs) como resultado do efeito piezoelétrico, ou seja, carga mecânica transformada em sinal elétrico (CARVALHO, CARVALHO \& CLIQUET 2001). 
O US pulsado tem efeito não térmico predominante e inclui o princípio da cavitação. Cavitação é um termo usado para descrever as atividades de microbolhas em um meio contendo líquido (sangue ou fluidos dos tecidos), quando estimulado acusticamente. Por isso é utilizado para propiciar diversos efeitos terapêuticos e principalmente para conduzir a entrega de agentes farmacológicos em tecidos profundos transdermicamente, sendo esta técnica denominada fonoforese ou sonoforese (HAAR, 1999; MASON, 2011).

A origem da cavitação ocorre quando os gases existentes nos tecidos aglutinam-se em pequenas bolhas que oscilam através do campo ultrassônico. Estas bolhas podem aumentar ou diminuir de volume, dependendo da variação no campo de pressão e, então, a cavitação pode ser classificada em estável e transiente (SCHLICHER et al., 2006):

a) Na cavitação estável, as bolhas formadas crescem pouco ou moderadamente em cada ciclo acústico. Ao atingirem determinado tamanho, estas bolhas entram em ressonância (microvibrações), permanecendo intactas. Esta corrente acústica produz microagitação das partículas, que resulta em constante circulação de fluídos com movimento unidirecional em um campo de pressão ultrassônica. Esta agitação localizada ao redor das bolhas e consequentemente às membranas celulares adjacentes e suas organelas, geram aumento na permeabilidade da membrana aos íons e metabólitos. Estes efeitos terapêuticos estão relacionados com ação analgésica, bem como, com o aumento do fluxo sanguíneo e do suprimento de nutrientes e oxigênio, que aumentam o metabolismo celular e aceleram o processo de reparação tecidual.

b) Na cavitação transiente, núcleos de gases crescem subitamente no meio, devido à alta intensidade ou presença de ondas estacionárias que causam variação de pressão acústica que podem ser aliadas ao aumento de temperatura produzida no local. Com isso estas bolhas de gases se colapsam violentamente, induzindo à desintegração dos tecidos adjacentes e à produção de radicais livres, resultando em lesões teciduais e até em queimaduras, que podem ser evitadas com o movimento contínuo do cabeçote. Portanto, devem-se evitar altas intensidades e ondas estacionárias.

A frequência do US na fonoforese entre 1 e $3 \mathrm{MHz}$ é classificada como terapêutica. Acima de $3 \mathrm{MHz}$ é alta frequência e abaixo de $1 \mathrm{MHz}$ é considerada de baixa frequência. Assim, pode se utilizar o regime contínuo de ondas para otimizar o tempo de interação do US com a droga e o tecido. Entretanto, na prática clínica o regime pulsado com frequência de 1 $\mathrm{MHz}$, permite o processo de reparação tecidual associado à técnica da fonoforese (KOEKE et al., 2005). 
O agente de acoplamento mais utilizado é o gel, pois apresenta maior porcentagem de transmissão em comparação com cremes e pomadas. Quando a aplicação da droga é feita pela pele, as bolhas rompidas no estrato córneo, através da fonoforese, possibilitam a desorganização da região lipídica da camada córnea, que pode aumentar sua permeabilidade (LAVON \& KOST, 2004).

A interação do US com os tecidos biológicos e a sua atenuação e dosimetria foi didaticamente descrita por Gama (2002). A energia do US tem natureza mecânica e decresce em intensidade à medida que se propaga em um meio. Quando a onda acústica encontra a interface entre dois meios diferentes ela pode ser parcialmente refletida e transmitida (refratada). A porcentagem de energia refletida e refratada depende do ângulo de incidência, conforme figura 3, e da diferença na impedância acústica dos meios. A impedância acústica (Z) é o produto da densidade do meio $(\rho)$ pela velocidade $(v)$ do ultrassom naquele meio. A onda refratada propaga-se no meio 2 com velocidade e comprimento de onda diferentes da do meio 1.

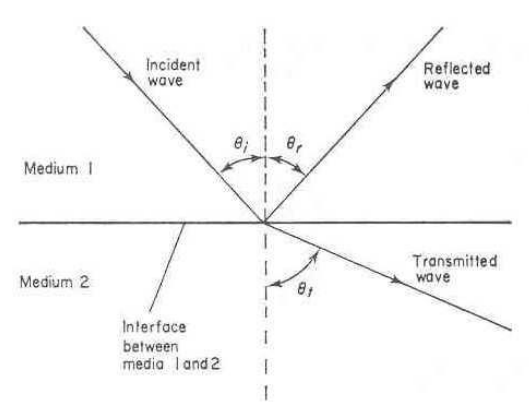

Figura 3 - Reflexão e refração do ultrassom (WELLS, 1977).

A impedância acústica de alguns tecidos é descrita na tabela 2 (WELLS, 1977).

Tabela 2 - Valores de Impedância Acústica

\begin{tabular}{|c|c|}
\hline Meio & $\begin{array}{c}\text { Impedância Acústica } \\
\text { Rayls }\left(\mathrm{Kg} \cdot \mathrm{m}^{-2} \cdot \mathrm{s}^{-1} \times 10^{6}\right)\end{array}$ \\
\hline $\mathrm{Ar}$ & 0.0004 \\
\hline Água & 1.52 \\
\hline Gordura & 1.35 \\
\hline Sangue & 1.62 \\
\hline Baço & $1.65-1.67$ \\
\hline Cérebro & $1.55-1.66$ \\
\hline
\end{tabular}


Tabela 2 (cont.) - Valores de Impedância Acústica

\begin{tabular}{|c|c|}
\hline Fígado & 1.62 \\
\hline Músculo & $1.65-1.74$ \\
\hline Pulmão & 0.26 \\
\hline Osso & $3.75-7.38$ \\
\hline Rim & $1.64-1.68$ \\
\hline
\end{tabular}

A porcentagem de energia refletida $\left(\mathrm{I}_{\mathrm{r}} / \mathrm{I}_{\mathrm{i}}\right)$ transmitida ou refratada $\left(\mathrm{I}_{\mathrm{t}} / \mathrm{I}_{\mathrm{i}}\right)$ é determinada pelas equações 1 e 2 , sendo $I_{i}, I_{r}$, e $I_{t}$ as intensidades incidente, refletida e transmitida, respectivamente. Os ângulos de incidência e transmissão são $\theta_{\mathrm{i}}$ e $\theta_{\mathrm{t}}$, respectivamente.

$$
\begin{aligned}
& \frac{I_{r}}{I_{i}}=\left(\frac{Z_{2} \cos \theta_{i}-Z_{1} \cos \theta_{t}}{Z_{2} \cos \theta_{i}+Z_{1} \cos \theta_{t}}\right)^{2} \\
& \frac{I_{t}}{I_{i}}=\frac{4 Z_{2} Z_{1} \cos \theta_{i} \cos \theta_{t}}{\left(Z_{2} \cos \theta_{i}+Z_{1} \cos \theta_{t}\right)^{2}}
\end{aligned}
$$

Se a incidência for perpendicular ao meio $2\left(\theta_{\mathrm{i}}=90^{\circ}\right)$ as equações 1 e 2 são simplificadas:

$$
\begin{gathered}
\frac{\mathrm{I}_{\mathrm{r}}}{\mathrm{I}_{\mathrm{i}}}=\left(\frac{\mathrm{Z}_{2}-\mathrm{Z}_{1}}{\mathrm{Z}_{2}+\mathrm{Z}_{1}}\right)^{2} \\
\frac{\mathrm{I}_{\mathrm{t}}}{\mathrm{l}_{\mathrm{i}}}=\frac{4 \mathrm{Z}_{2} \mathrm{Z}_{1}}{\left(Z_{2}+\mathrm{Z}_{1}\right)^{2}}
\end{gathered}
$$

A potência do US que atinge um sítio ósseo é menor que a potência transmitida pelo transdutor devido a atenuação nas camadas de tecidos entre a pele e o sítio e a reflexão na interface entre tecidos. A atenuação é determinada pela equação 5 , sendo $\mathrm{P}$ a potência que atinge um determinado meio e $\mathrm{P}_{\text {ref }}$ uma potência de referência. A unidade de medida da atenuação é o decibel (dB). A atenuação aumenta com a frequência de propagação do US.

$$
\mathrm{A}=10 \log \frac{\mathrm{P}}{\mathbf{P}_{\text {ref }}}
$$

A atenuação do ultrassom em um determinado meio por unidade de comprimento é denominada de coeficiente de atenuação e expressa em $\mathrm{dB} / \mathrm{cm}$. A atenuação total do US ao se propagar em um meio é o produto do coeficiente de atenuação deste meio pela espessura do mesmo. A tabela 3 descreve o coeficiente de atenuação de alguns tecidos na frequência de 1.5 MHz (ZISKIN, 1989). 
Tabela 3 - Coeficientes de Atenuação de Tecidos

\begin{tabular}{|c|c|}
\hline Tecido & $\begin{array}{c}\text { Coeficiente de } \\
\text { Atenuação }(\mathrm{dB} / \mathrm{cm})\end{array}$ \\
\hline Pele & 2.60 \\
\hline Gordura & 0.91 \\
\hline Músculo & 1.43 \\
\hline
\end{tabular}

Nesta investigação o US de baixa intensidade foi transmitido através da pele da região com fratura. A incidência do ultrassom foi perpendicular a pele, póstero-ventral, com um transdutor de área de efetiva de $3.88 \mathrm{~cm}^{2}$, transmitindo uma potência de $117 \mathrm{~mW}$, o que equivale a uma intensidade de $30 \mathrm{~mW} / \mathrm{cm}^{2}$.

A energia transmitida pelos transdutores ultrassônicos para uso em saúde deve ser periodicamente aferida, isto é, deve ser realizada a dosimetria do equipamento de ultrassom, cujo princípio é descrito a seguir.

Um campo ultrassônico que atinge um objeto exerce uma força, denominada força de radiação $\left(\mathrm{F}_{\mathrm{rad}}\right)$, que é proporcional a potência incidente. Se o objeto absorver completamente a energia incidente, a expressão da força é dada pela equação 6 , sendo c a velocidade do ultrassom no meio onde o objeto está imerso (ZISKIN \& LEWIN, 1993).

$$
\mathrm{F}_{\mathrm{rad}}=\frac{\mathrm{W}}{\mathrm{c}}
$$

Dosímetros de US que têm como base a força de radiação são disponíveis comercialmente sendo denominados de "Balança de Força de Radiação" em virtude da força ser medida com o auxílio de uma balança mecânica ou eletrônica. Eles são utilizados nas aferições de transdutores ultrassônicos utilizados em terapia. O diagrama esquemático deste dosímetro é mostrado na figura 4.

A dosimetria deve ser realizada nas seguintes condições:

- $\quad$ Uso de água degaseificada para evitar a reflexão do ultrassom por bolha de ar.

- Alvo cônico de $45^{\circ}$ com perfeita geometria para evitar reflexões na parede do absorvedor.

- $\quad$ Balança de precisão.

- $\quad$ Ausência de distúrbios do ambiente como vibração do suporte do dosímetro ou correntes de ar. 


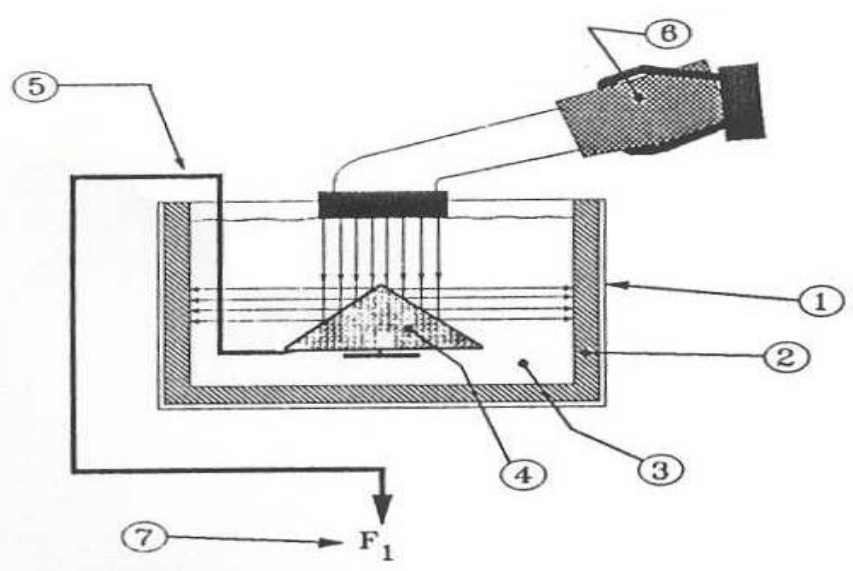

Figura 4 - Balança de força de radiação: 1- tanque de dosimetria; 2- absorvedor da energia refletida pelo alvo; 3 água degaiseficada; 4- alvo; 5- acoplamento do alvo com a balança; 6- transdutor ultrassônico; 7- balança (Ohmic Instruments, EUA).

Na figura 5 observa-se um dosímetro comercial (UPM-DT-1, Ohmic Instruments, EUA) para medida de potências de $1 \mathrm{~mW}$ à $30 \mathrm{~W}$ construído com base no princípio da balança de radiação. Esse modelo foi utilizado nesta investigação para dosimetria do transdutor ultrassônico.

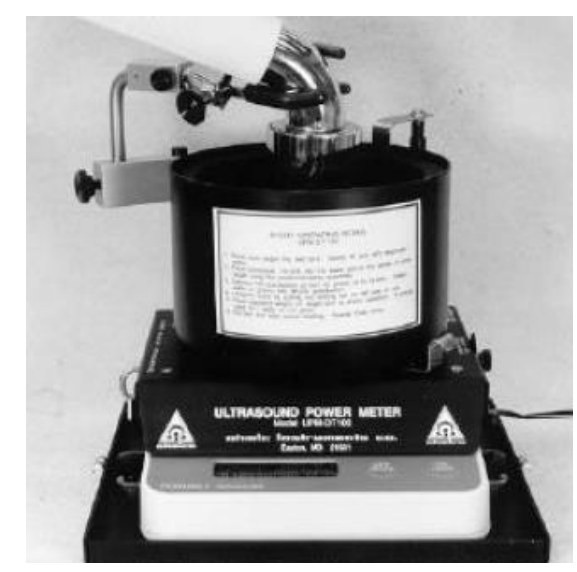

Figura 5 - Dosímetro de US comercial com base no princípio da balança de radiação (Ohmic Instruments, EUA).

A intensidade acústica medida é a SATA (space average time average) que representa o quociente entre a potência acústica (W) medida, por exemplo, por uma balança de radiação, e a área efetiva de radiação do transdutor. O sinal elétrico que excita o transdutor ultrassônico pode ser contínuo ou pulsado. Na figura 6 observam-se as características do sinal elétrico que excitou o transdutor utilizado nessa investigação (burst senoidal com frequência de $1.5 \mathrm{MHz}$, frequência de repetição de $1 \mathrm{KHz}$ e largura de pulso de $200 \mu \mathrm{s}$ ). 


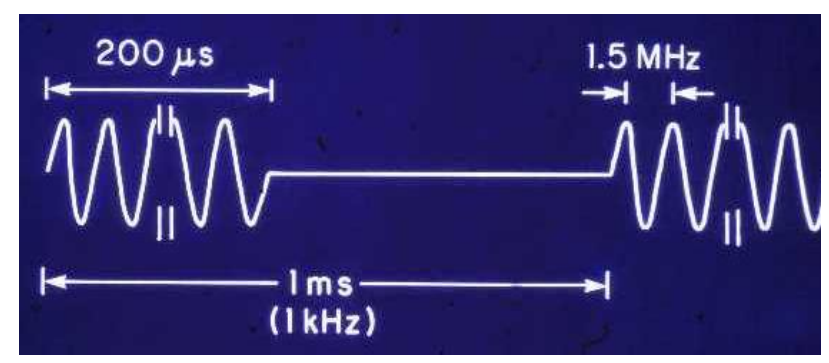

Figura 6 - Sinal elétrico aplicado ao transdutor de ultrassom.

\subsection{Tecido Ósseo}

O tecido ósseo difere de outros tecidos, pois se renova constantemente ao longo da vida e adapta sua microestrutura conforme as cargas mecânicas que lhe são impostas (ROBLING; CASTILLO \& TURNER, 2006). Considerado o mais resistente tecido do corpo humano desempenha funções de proteção, reservatório extracelular de cálcio e fósforo, além de alojar e proteger a medula óssea (função hematopoiética). Constitui o sistema de alavancas musculares, transformando as contrações em deslocamentos dos segmentos corpóreos no espaço e consequentemente em movimentos funcionais, como o ato de caminhar ou pegar e transportar objetos.

O osso é composto por hidroxiapatita, colágeno, pequena quantidade de proteoglicanas, proteínas não-colagenosas e água. A matriz óssea é constituída por duas partes: a) a inorgânica, que confere resistência à compressão e rigidez; b) a orgânica, responsável pela elasticidade, resistência à tração, além de ser um material poroso, não homogêneo, anisotrópico (resiste de maneira diversa às cargas aplicadas em diferentes direções) e não-linear (KALFAS, 2001). Porém, a composição do osso varia de acordo com a espécie, a idade, o sexo, tipo, hormônios, bem como a fisiopatologia de doenças que podem comprometer a sua estrutura (MACDONALD et al. 2011).

Existem dois tipos de tecido ósseo: o cortical ou compacto que se apresenta como um tecido rígido e denso, enquanto o trabecular ou esponjoso é constituído por uma rede tridimensional de trabéculas ósseas e por espaços intersticiais. O tecido cortical envolve o trabecular, porém, conforme as demandas funcionais ocorrem variações da quantidade relativa entre os ossos (GROSS \& RUBIN, 1995). Apresentam funções de proteção, mecânicas e metabólicas, sendo que o trabecular é metabolicamente mais ativo que o cortical e fornece suprimento inicial nos estados de deficiência mineral, como na osteoporose. $\mathrm{O}$ 
tecido ósseo trabecular possui estrutura menos densa com porosidade de 50 a $95 \%$ e é encontrado, por exemplo, em ossos planos e nas extremidades dos ossos longos (DOBLARÉ; GARCÍA \& GÓMEZ, 2004).

O tecido ósseo cortical apresenta porosidade de 5 a $10 \%$, é encontrado na diáfise dos ossos longos e circundando o osso trabecular. Ainda, é constituído por estruturas cilíndricas conhecidas como ósteons, que são estruturas de 100 a $150 \mu \mathrm{m}$ de raio, situados ao longo do eixo do osso, contendo um canal no seu centro. Esse canal possui vasos sanguíneos, nervos, espaços ocupados por fluido ósseo e suas paredes apresentam aberturas para os canalículos (COWIN, 1998). Assim, cada ósteon é composto por um canal haversiano central, envolvido por uma série de lamelas concêntricas de matriz óssea, contendo nervos e vasos capilares sanguíneos.

O diâmetro dos canais de Havers, que percorrem o osso longitudinalmente, é da ordem de $50 \mu \mathrm{m}$ e ao redor de cada canal, pode-se observar várias lamelas concêntricas de substância intercelular e de células ósseas. Os canais de Volkmann partem da superfície do tecido ósseo, possuindo uma trajetória perpendicular em relação ao maior eixo do osso e não apresentam lamelas concêntricas. Esses canais se comunicam com os de Havers por projeções laterais. A Figura 7 mostra a estrutura óssea em diferentes escalas.

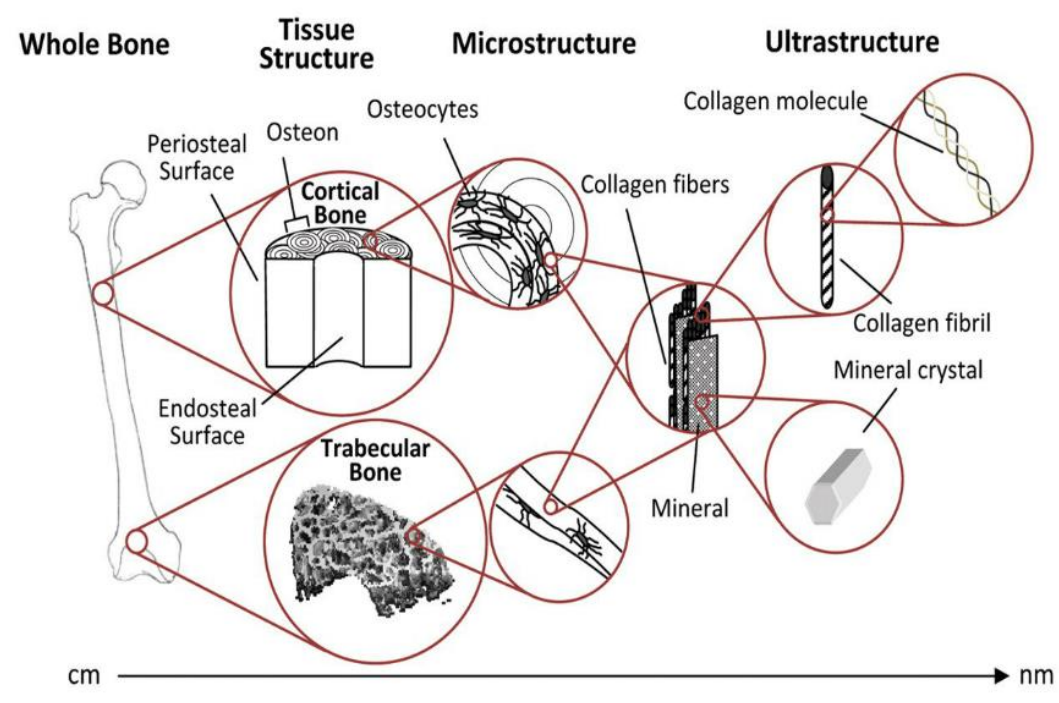

Figura 7 - Principais estruturas que compõe o tecido ósseo (BOSKEY \& COLEMAN, 2010).

Cada conjunto formado pelo canal central de Havers e pelas lamelas concêntricas constitui o sistema de Havers ou sistema haversiano. Os canais de Volkmann (canais transversais que se conectam aos canais de Havers) permitem a comunicação entre os canais de Havers e entre estes com as interfaces de osso cortical. Entre as lamelas concêntricas se 
encontram cavidades onde estão as células (lacunas osteocitárias) interconectadas pelos canalículos (PAZZAGLIA et al., 2010).

Os ossos são revestidos externa e internamente por membranas denominadas periósteo e endósteo, respectivamente. Ambas são vascularizadas sendo importantes para a nutrição e oxigenação das células do tecido ósseo, além de fornecer osteoblastos para o crescimento dos ossos e reparação de fraturas. A camada mais superficial do periósteo contém, principalmente, fibras colágenas e fibroblastos. As fibras de Sharpey são feixes de fibras colágenas do periósteo que penetram no osso realizando sua ancoragem. A camada mais interna do periósteo é composta por células osteoprogenitoras.

O endósteo é composto por uma camada de células osteoprogenitoras achatadas que reveste as cavidades do osso trabecular, do canal medular e dos canais de Havers e Volkmann.

As células que constituem o tecido ósseo são classificadas em quatro tipos: i) as células osteoprogenitoras que possuem potencial para se diferenciarem em osteoblastos; ii) os osteoblastos que são responsáveis pela síntese dos componentes orgânicos da matriz óssea, inclusive as fibras colágenas e proteínas não colagenosas, bem como possibilitam a mineralização da matriz óssea; iii) os osteócitos que são responsáveis pela manutenção do tecido ósseo; e iv) os osteoclastos que realizam a reabsorção deste mesmo tecido (DOBLARÉ; GARCÍA; GÓMEZ, 2004).

Os osteoblastos sintetizam os componentes da matriz orgânica e participam da mineralização da matriz pela concentração de fosfato de cálcio. Estão dispostos lado a lado nas superfícies ósseas, conectados por prolongamentos citoplasmáticos, semelhante ao epitélio simples. Quando um osteoblasto é envolvido pela matriz óssea recém-sintetizada ele passa a constituir um osteócito. Assim, osteoblastos e osteócitos representam as mesmas células em estágios funcionais diferentes (CLARKE, 2008). O osteoclasto é derivado de células hematopoiéticas progenitoras que também dão origem aos monócitos e macrófagos. Apresenta-se multinucleado e é responsável pela reabsorção óssea, que através da sua ação enzimática, escavam a matriz óssea formando depressões denominadas lacunas de Howship. A diferenciação e maturação do osteoclasto em humanos ocorrem pela ação das citocinas e dos fatores de crescimento, como as interleucinas (IL-1, IL-3, IL-6, IL-11), o fator de necrose tumoral (TNF), fator estimulante de colônia de granulócitos-macrófagos (CSF-GM), entre outros. Esses fatores estimulam as células progenitoras de osteoclastos ou participam do sistema parácrino, em que atuam os osteoblastos e as células do estroma da medula óssea (TEITELBAUM \& ROSS, 2003; TEITELBAUM, 2007). 
Os osteócitos são as células em maior quantidade do tecido ósseo e encontram-se nas cavidades ou lacunas da matriz óssea. Desta lacuna formam-se canalículos que se conectam com outros canalículos das lacunas vizinhas, tornando a difusão de nutrientes possível graças a essa comunicação entre os osteócitos, que participam da manutenção da integridade da matriz óssea, a partir da detecção das alterações físicas e químicas do tecido ósseo, recrutando em seguida, osteoblastos e osteoclastos para as funções de síntese e reabsorção (DATTA et al., 2008). Assim, as células derivadas dos osteoblastos, após cumprir sua função de síntese, são envolvidas por conteúdo mineral e permanecem nas lacunas, sendo responsáveis pela manutenção do tecido ósseo.

Ainda, segundo a classificação histológica, este tecido pode ser imaturo (woven, primário ou não lamelar) e maduro (secundário ou lamelar). Ambos possuem as mesmas células e os mesmos constituintes da matriz óssea, porém, apresentam diferentes organizações tridimensionais de suas fibras de colágeno.

O tecido ósseo primário é o primeiro tipo de tecido que aparece na formação da estrutura óssea. A matriz neste estágio apresenta feixes entrelaçados de fibras colágenas, sem organização definida, contendo grande número de osteócitos irregularmente distribuídos no interior das trabéculas ósseas neoformadas. O tecido ósseo secundário apresenta fibras colágenas organizadas em lamelas, dispostas paralelamente umas às outras, em camadas concêntricas em torno de um canal central, o canal de Havers. Neste canal correm vasos sanguíneos e nervos que se comunicam entre si, com a cavidade medular e com a parte externa do osso, por canais transversais (ou oblíquos), os canais de Volkmann (JUNQUEIRA \& CARNEIRO, 2008).

Para a integridade do tecido ósseo é necessário que haja um equilíbrio entre a formação e a reabsorção, isto é, na atividade dinâmica dos osteoblastos e osteoclastos. Assim, para se adaptar à carga mecânica funcional, o tecido ósseo possui um sistema que reconhece a intensidade do estímulo mecânico. A diminuição deste estímulo promove a reabsorção enquanto o seu aumento favorece a preservação e a formação óssea. Ainda, as células ósseas devem ser capazes de responder à diminuição ou à ausência de carga, iniciando a reabsorção do tecido. As alterações das propriedades bioquímicas, morfológicas e/ou biomecânicas do tecido ósseo podem ocorrer devido ao processo de envelhecimento, imobilização, ausência de carga, doenças metabólicas ou neuromusculares, bem como a realização de exercícios físicos (DUNLOP et al., 2009).

Neste contexto, o remodelamento ósseo não ocorre somente para repor tecido que foi lesado, como no caso de uma fratura, mas também em decorrência da capacidade de 
adaptação do osso às demandas mecânicas e às alterações nutricionais e/ou metabólicas a que está sujeito.

A remodelação óssea é descrita como uma sequência de ativação-reabsorçãoformação, sendo que após um determinado estímulo, uma região óssea é ativada, reabsorvida e novamente formada. Aproximadamente $25 \%$ do osso trabacular e $3 \%$ do cortical são renovados anualmente (GARTNER \& HIATT, 2003; DEMPSTER et al., 1995).

No caso de lesão consumada do osso, isto é, de uma fratura, tanto os aspectos físicos quanto circulatórios desse tecido são comprometidos. Porém, a partir de um processo biológico, ocorre a formação de um novo tecido ósseo visando à consolidação dessa fratura (EINHORN, 1998).

O reparo ósseo é um processo regenerativo complexo que consiste na interação de vários eventos biológicos, como a síntese ativa de genes, a ação de células e proteínas, que determinarão a restauração da integridade do tecido ósseo.

\subsection{Microtomografia por Raio-X $(\mu \mathrm{CT})$}

A microtomografia por raio-x $(\mu \mathrm{CT})$ é uma técnica não destrutiva que reconstrói o interior de um objeto em escala micrométrica ou nanométrica, gera informações sobre sua geometria tridimensional e propriedades do material a partir da interação da radiação com a matéria, sendo que as radiações têm sua intensidade diminuída em função do material que as absorve (DYSON, 1993).

Os componentes de um microtomógrafo são esquematicamente mostrados na figura 8 (MILANETTI, 2010): a) fonte de raio-x com um foco de dimensão micrométrica e um feixe cônico. Um filtro metálico de alumínio ou cobre de pequena espessura deve ser colocado na frente da fonte para reduzir o efeito denominado de "endurecimento de feixe"; b) manipulador do objeto através de mesa com movimento de precisão rotacional $(\theta)$ e translacional (direções $\mathrm{X}, \mathrm{Y}$ e Z) onde é fixado o objeto a ser analisado; c) detector de radiação (câmera CCD) para aquisição das projeções do objeto. 


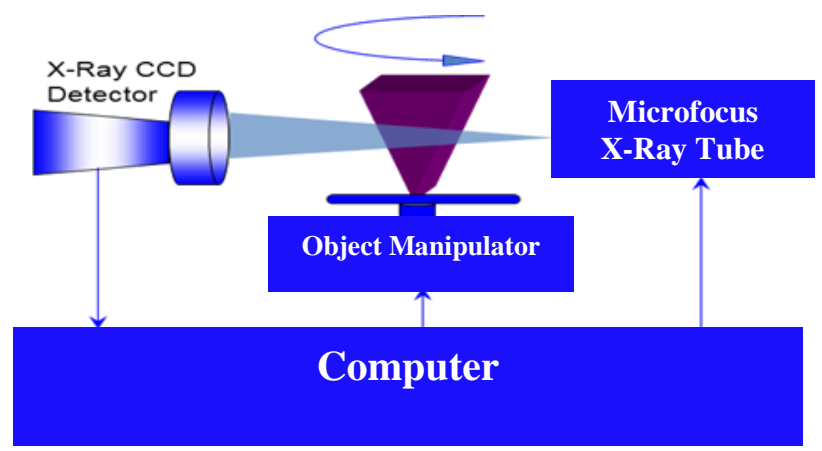

Figura 8 - Componentes de um microtomógrafo (MILANETTI, 2010).

Na figura 9 observa-se que as projeções de uma amostra de osso trabecular, obtidas a cada pequeno incremento angular de um manipulador de objeto, são processadas por algoritmos (FELDKAMP; DAVIS \& KRESS, 1984) para gerar as reconstruções 2D e 3D da sua estrutura.

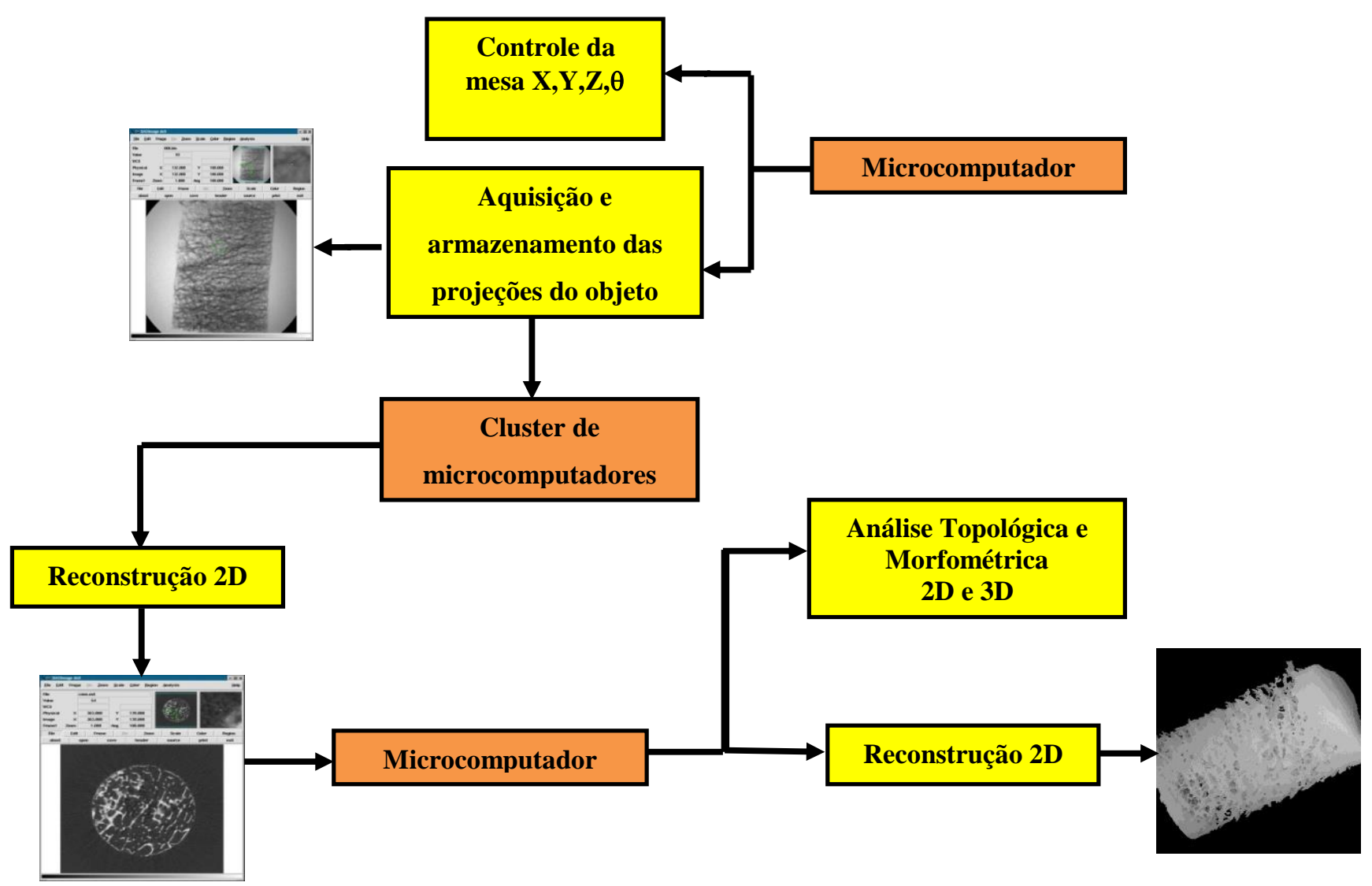

Figura 9 - Etapas da microtomografia computadorizada por raios-x (MILANETTI, 2010).

A imagem 3D de um objeto é um mapeamento 3D da absorção local do raio-x no objeto. A reconstrução através de múltiplas projeções fornece informação da absorção do 
raio-x em cada voxel do volume escaneado. A intensidade em níveis de cinza de cada voxel da imagem não tem relação direta com a medida de densidade volumétrica. $O$ parâmetro primário medido é a absorção do raio-x definida como coeficiente de atenuação linear (AC ou $\left.\mu, \mathrm{mm}^{-1}\right)$. A microtomografia com cone de radiação, produzida por fontes focais de raio-x, calcula o coeficiente de atenuação para cada voxel do objeto escaneado.

Quando um feixe de raios-X com intensidade $\mathrm{I}_{\mathrm{O}}$ atravessa um objeto com espessura $\mathrm{x}$, conforme a figura 10, a intensidade de radiação I após a propagação é dada pela equação (7), onde $\mu$ é o coeficiente de atenuação linear do material. Se a trajetória do feixe inclui regiões com diferentes coeficientes de atenuação $\left(\mu_{1}, \mu_{2}, \ldots \mu_{n}\right)$ então a intensidade I é dada pela equação (7).

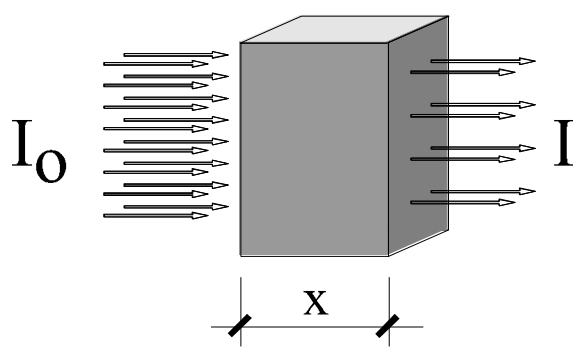

Figura 10 - Atenuação de um feixe de fótons por uma amostra (SILVA, 2009).

$$
\begin{gathered}
I=I_{0} e^{-\mu x} \\
I=I_{0} e^{-\sum_{i=1}^{n} \mu_{i} x_{i}}
\end{gathered}
$$

O conhecimento de que a absorção do raio-x é dominada por um material específico permite relacionar o coeficiente de atenuação à densidade daquele material. A calibração da densidade mineral óssea (BMD) é um exemplo. Assume-se que a atenuação do raio-x nos tecidos mineralizados, como o osso, dentina e esmalte dentário é dominada pela atenuação da hidroxiapatita de cálcio [CaHa, $\left[\mathrm{Ca}_{5}\left(\mathrm{PO}_{4}\right)_{3} \mathrm{OH}\right]$. Phantoms com concentrações conhecidas dessa substância são utilizados na calibração, conforme figura 11. A calibração nos microtomógrafos da Bruker (Bélgica, Holanda) resulta em uma equação que relaciona a BMD com o coeficiente de atenuação ou com unidades de densidade expressas em Hounsfield (HU) cujo valor varia de -1000 para o ar e 0 para a água.

A calibração com relação à $\mu$ é a mais comum. A densidade mineral óssea (BMD) é definida como a densidade volumétrica $\left(\mathrm{g} . \mathrm{cm}^{-3}\right)$ da CaHA. A BMD está relacionada à densidade combinada em um volume contendo uma mistura de osso e tecido mole. Nesse caso 
a BMD se refere à massa óssea dentro daquele volume, mas não fornece informação da densidade do tecido ósseo. A TMD, densidade mineral do tecido, está relacionada à densidade do tecido ósseo, excluindo a contribuição ao volume do tecido mole.
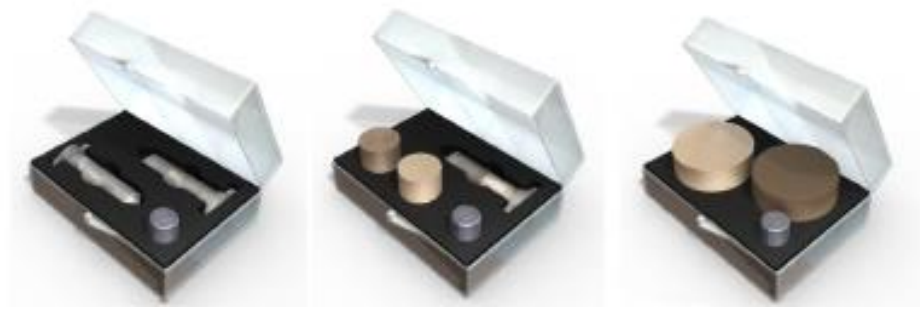

Figura 11 - Cilindros com diâmetros de 2-4 mm, 8-16 mm e $32 \mathrm{~mm}$ e com concentrações de $0,25{\mathrm{~g} . \mathrm{cm}^{3}}^{3}$ e 0,75 g. $\mathrm{cm}^{3}$ de CaHA da Bruker Micro CT utilizados para calibração da medida de BMD (Bruker Method Note, 2012).

Devido ao efeito denominado de endurecimento de feixe, associado à propagação do raio-x em um objeto, o tamanho de um objeto afeta levemente a medida do coeficiente de atenuação, conforme figura 12. Dessa maneira, o diâmetro do phantom deve ser próximo da seção transversal da amostra cuja densidade mineral é medida. $\mathrm{O}$ diâmetro de $4 \mathrm{~mm}$ é o indicado para amostras de fêmur, tíbia e vértebra de ratos.

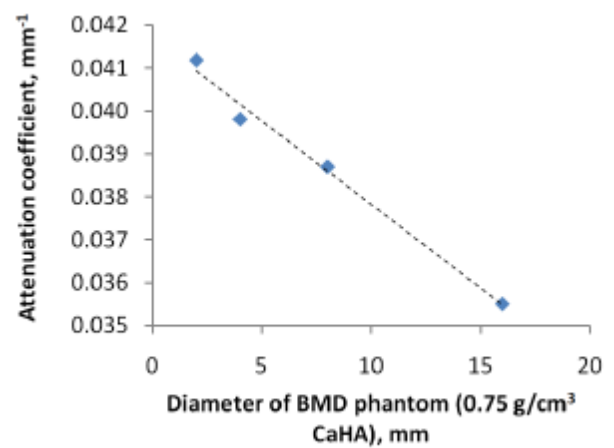

Figura 12 - O aumento do diâmetro de um phantom de CaHA diminui a medida do coeficiente de atenuação (Bruker Method Note, 2012).

Os tecidos moles que envolvem um osso, como a pele, gordura e músculo, afetam significativamente a medida da densidade mineral. Quando o escaneamento in-vivo de membros de roedores é realizado, a calibração da BMD deve ser realizada com os phatoms imersos em tubo de água cujas dimensões devem ser próximas da largura do membro do animal. A água, em geral, apresenta o mesmo coeficiente de absorção de tecidos moles. O membro que está sendo escaneado não precisa permanecer no centro do tubo. 


\subsubsection{Procedimentos de Armazenamento e Escaneamento de Amostras Ósseas}

$\mathrm{O}$ armazenamento de amostras ósseas pode ser realizado da seguinte maneira: a) em freezer à $-20^{\circ} \mathrm{C}$ com as amostras envolvidas em gaze que foram umedecidas com solução salina; b) fixação em solução tamponada fosfatada; c) fixação em álcool ou formalina tamponada com posterior fixação em álcool. Nesse caso, antes do escaneamento, a amostra deve ser reidratada em solução fisiológica salina de $0.9 \%$.

As amostras ósseas devem ser mantidas hidratadas durante o escaneamento para a medida da BMD ou TMD. Nos escaneamentos ex-vivo uma opção é manter a amostra em tudo plástico de água assim como o phantom para medida de BMD durante o procedimento de calibração utilizando-se um tubo idêntico. Um segundo método é envolver a amostra com um lenço umedecido em água destilada ou solução fisiológica e colocá-la em um porta amostra plástico, conforme figura 13. Uma terceira alternativa é envolver a amostra em filme plástico que não contenha PVC.

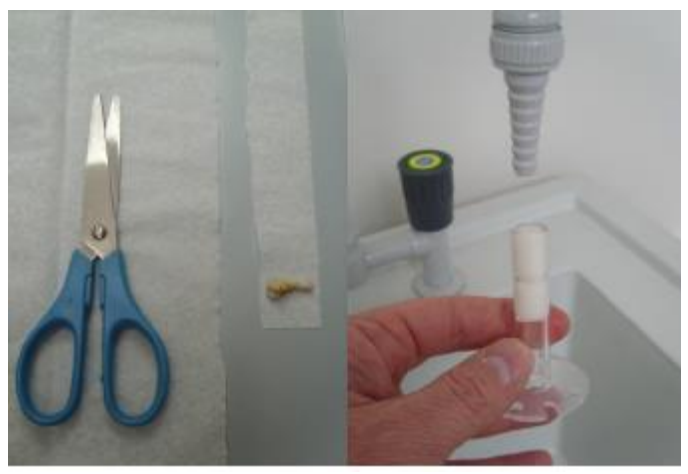

(A)

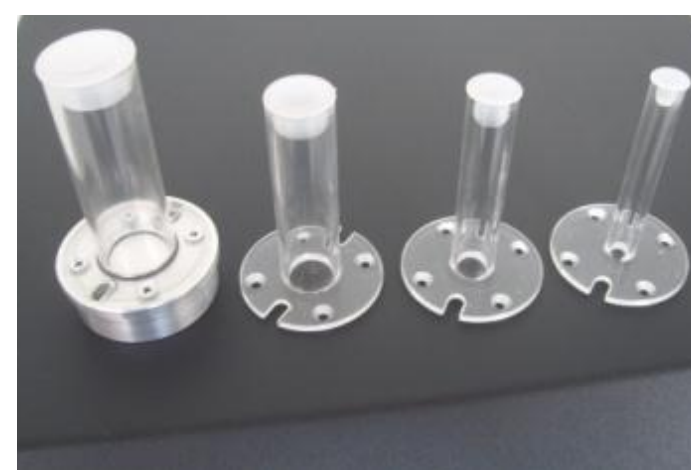

(B)

Figura 13 - Procedimento de hidratação de amostras ósseas para escaneamento: (A) uso de lenço de papel umedecido, B) porta amostra plástico (Bruker Method Note, 2012).

\subsubsection{Endurecimento de Feixe e Filtros Metálicos}

A maior fonte de erro em medidas de densidade por $\mu \mathrm{CT}$ é o "endurecimento de feixe" que é causado por uma fonte policromática de raio-x. Na radiação dessas fontes estão presentes raio-x com energia maiores ("raio-x duro") e menores ("raio-x mole"). Quando o raio-x se propaga pela amostra as energia menores são mais atenuadas que as maiores. Isto resulta em artefato na imagem reconstruída com a presença de densidades maiores na superfície do objeto. Esse efeito é aproximadamente corrigido pelos softwares de reconstrução, mas o melhor método é o uso de um filtro de metal (alumínio ou cobre ou 
ambos) cuja espessura depende da amostra que está sendo escaneada. A espessura de filtro de alumínio dever ser de $0,75 \mathrm{~mm}$ a $1 \mathrm{~mm}$ para ossos de rato.

\subsection{Interação Fotoacústica}

O fenômeno fotoacústico foi descoberto por Alexander Graham Bell em meados de 1880. Bell observou que a incidência de luz solar modulada em uma superfície sólida em forma de diafragma produzia som audível e, com isso, mostrou que a intensidade do sinal acústico dependia da absorção da luz pela matéria no qual era incidida. Com esta concepção Bell desenvolveu o "fotofone" que deu origem ao telefone (CHIVUKULA; SHUR \& CIPLYS, 2007).

O princípio fotoacústico baseia-se na produção de uma onda acústica num meio pela interação dos fótons com a matéria, no qual as ondas podem ser captadas por um microfone sensível e assim, passa a ser utilizado na física, biologia e medicina. $\mathrm{O}$ efeito fotoacústico gera ondas acústicas e efeitos térmicos por qualquer tipo de matéria que absorva radiação e com isso pode-se obter informações sobre as propriedades ópticas, acústicas, térmicas, entre outras.

Em relação aos materiais biológicos, por exemplo, o tecido ósseo, muscular e cutâneo, esta técnica tem sido utilizada no diagnóstico clínico, para obtenção de imagens médicas por sistema fotoacústico (Figura 3), bem como, para caracterização dos tecidos biológicos através da espectroscopia fotoacústica.

Os sistemas fotoacústicos para imagens médicas apresentam diferentes posicionamentos das tecnologias Laser e US. A figura 14 mostra primeiramente o transdutor de US e o laser posicionados perpendicularmente $\left(90^{\circ}\right)$ e, também com o arranjo de laser localizado a cada lado do transdutor de US (BEARD, 2011; CHIVUKULA; SHUR \& CIPLYS, 2007). Ainda, o laser pode ser posicionado ao lado oposto do transdutor de US $\left(180^{\circ}\right)$ (WANG et al., 2012; BEARD, 2011). 

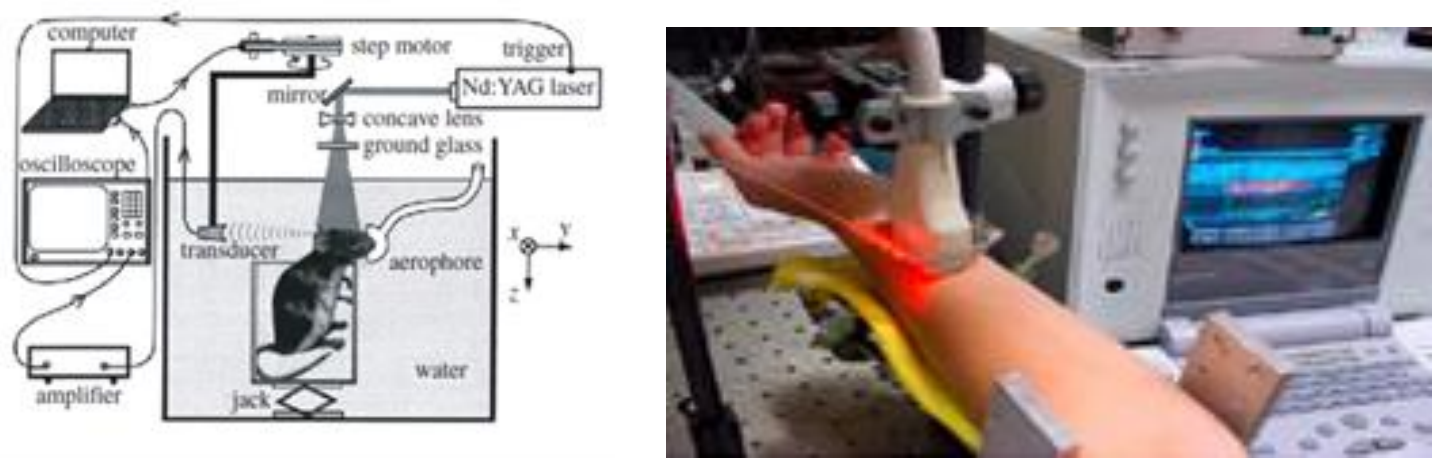

Figura 14 - Sistemas fotoacústicos para imagens médicas. Fonte: (BEARD, 2011; CHIVUKULA; SHUR \& CIPLYS, 2007). 


\section{REVISÃO DE LITERATURA}

A resposta de reparo ósseo pode ser acentuada por meio de vários métodos, como estimulação bioquímica por hormônios, fatores de crescimento, enxerto ósseo e pela estimulação física por modalidades mecânicas e eletromagnéticas (LIND \& BUNGER, 2001).

O ultrassom pulsado de baixa intensidade (LIPUS) tem sido utilizado com esta finalidade e seus efeitos biológicos comprovados na reparação de fraturas em experimentos animais (DUARTE, 1983; PILLA et al., 1990; WANG et al., 1994; MAYR et al., 2001; TAKIKAWA et al., 2001), em experimentos clínicos com fraturas recentes (HECKMAN et al., 1994); (KRISTIANSEN et al., 1997), em experimentos clínicos com fraturas com nãounião (XAVIER \& DUARTE, 1983; NOLTE et al., 2001; MAYR et al. 2000), em experimentos clínicos com fraturas com retardo de consolidação (RUTTEN et al., 2008) em experimentos clínicos com transporte ósseo (GOLD \& WASSERMAN, 2005), em experimentos clínicos com alongamento ósseo (SATO et al., 1999; El-MOWAFI \& MOHSEN, 2005; CHAN et.al, 2006a; CHAN et. al, 2006b), em experimentos clínicos com fraturas por stress (GIANINNI et al., 2004; RUE et al., 2004) e em experimentos clínicos com osteotomia (TSUMAKI et al., 2004). O mecanismo de ação mais intensamente investigado do LIPUS é o da ação da energia mecânica nas integrinas que são mecanoreceptores presentes na membrana celular de várias células envolvidas no reparo ósseo (POUNDER \& HARRISON, 2008). A expressão de osteocalcina que tem ação na mineralização e homeostase de íons de cálcio no organismo foi também investigada (RENNÓ et.al, 2011). A tecnologia foi citada em várias revisões de literatura sobre técnicas de tratamento de fratura (EINHORN, 1995; HANNOUCHE et al., 2001; MARSELL \& EINHORN, 2010). Há várias revisões sobre os efeitos da técnica em reparo ósseo (RUBIN et.al, 2001; CLAES \& WILLIE, 2007; SISKA et.al, 2008). É significativa a existência de análises estatísticas por meta-análise sobre a tecnologia (BUSSE et.al, 2002; SNYDER et al. 2012) porque demonstram que a técnica foi investigada em vários países e por diferentes investigadores.

O mesmo ocorre com a fototerapia, estudos in vitro mostram que o laser aumenta a atividade mitocondrial (PIRES-OLIVEIRA et al., 2008), a síntese óssea e a proliferação osteoblástica (RENNÓ et al., 2007; STEIN et al., 2005). Resultados promissores e efeitos positivos no metabolismo ósseo e na consolidação de fraturas também foram comprovados 
em procedimentos experimentais com ratos (BARUSHKA; YAKOBI \& ORON, 1995) e coelhos (LIU et al., 2007), tanto em defeitos ósseos (GARAVELLO-FREITAS et al., 2003) quanto em osteotomia (BARBOSA et al., 2013). Após irradiação com laser constatou-se osteogênese (PRETEL; LIZARELLI \& RAMALHO, 2007; BLAYA et al., 2008) e redução do tempo de consolidação (NICOLAU et al., 2003), além do aumento da densidade mineral e volume do calo ósseo (LIU et al., 2007); notando-se melhora das propriedades biomecâncas do osso (LUGER et al., 1998), como a força, durante o processo de reparo (SON et al., 2012). Um importante aspecto da consolidação de fraturas é a nutrição adequada do tecido ósseo, ação que o laser tem favorecido apartir do aumento da vascularização, com consequente aumento na rapidez da formação do osso (TRELLES \& MAYAYO, 1987). Estudos também evidenciam que com a utilização da fototerapia há o aumento da regeneração óssea e osteointegração de implantes dentários (JAKSE et al., 2007). Assim, quando o laser é aplicado em tecido biológico, a luz é absorvida pelos fotoaceptores localizados nas células e quando absorvida, a luz pode modular as reações bioquímicas celulares e estimular a respiração mitocondrial, com a produção de oxigênio molecular e síntese de ATP (KARU, 1989) para propiciar efeitos terapêuticos. Em estudo clínico controlado e randomizado (CHAUHAN \& SARIN, 2006) foram investigados os efeitos do laser no tratamento de fraturas por estresse em tíbia, pois o tratamento nesse quadro clínico inclui repouso, compressão, elevação e alongamento passivo. Os autores constataram efeitos analgésicos e redução do edema, principalmente ao retorno da deambulação e com pouca recorrência de sintomas, o que aumenta a funcionalidade dos pacientes. Neste contexto, o estado da arte desta técnica (PINHEIRO \& GERBI, 2006) indica que vários grupos investigam a ação da fototerapia sobre o tecido ósseo, sendo promissora para uso clínico.

Ainda, a revisão da literatura nesta área mostra que somente um estudo avaliou a interação do US com o Laser no processo de consolidação de fraturas em ratos (AL-HABIB et al., 2011).

Em experimento animal, Lirani (2004) constata que ambos os agentes físicos promoveram mudanças na reparação óssea, mas em diferentes fases de reparo. O LIPUS aumentou a reparação promovendo a reabsorção óssea na área fraturada enquanto o Laser acelerou esse processo por meio da formação óssea e do aumento da resistência mecânica máxima quando comparado aos grupos experimentais que realizaram o LIPUS e aquele que não realizou nenhum tratamento. Ainda, de acordo com os resultados deste estudo, conclui-se que tanto o laser terapêutico quanto o ultrassom de baixa intensidade foram capazes de aumentar a área 
de tecido ósseo neoformado, acelerando o processo de reparo ósseo após a indução do defeito em tíbias de ratos.

Em estudo com animais, Marino (2003) investiga o efeito da fototerapia no reparo ósseo em tíbia de ratos e constata a existência de uma suposta ação modulatória sobre o processo inflamatório, como reabsorção mais rápida de exudatos e aumento da atividade fagocitária, que contribuem para uma osteossíntese inicial mais ativa.

Trelles et al. (1992) relata uma formação mais rápida de calo e vascularização em fraturas induzidas em ratos após 12 irradiações consecutivas de laser He-Ne, a partir de observações histológicas não quantitativas.

Em outro estudo com ratos, o grupo de Garavello-Freitas (2003) constata que a fototerapia estimula o crescimento da área trabecular e a concomitante invasão de osteoclastos durante a primeira semana de tratamento pós-osteotomia da tíbia e acelera a organização de colágeno da matriz ao final da segunda semana.

Poppi et al. (2011), em procedimento experimental, avaliam os efeitos do laser de baixa potência no processo de reparo dos defeitos ósseos em fêmur de ratas ovariectomizadas e constatam que ambos os comprimentos de onda (660 e 880nm) inibem o processo inflamatório e induzem a proliferação das células que participam dos processos de reparo e remodelamento ósseo.

A utilização dessas tecnologias pode ser uma opção para vários casos, pois, com o aumento da expectativa de vida as pessoas apresentam perda óssea de várias etiologias e fraturas. O mesmo ocorre com o maior número de acidentes que geram lesões severas, bem como, contribuição para a regeneração óssea nas cirurgias ortopédicas corretivas. Também pode ter aplicação na medicina desportiva, sendo que os pacientes são na maioria jovens e ativos (LAVIGNE et al., 2008) e o retorno à funcionalidade o quanto antes é esperada. Outra aplicação pode ocorrer na área veterinária (MORAES, 2006) pela dificuldade de se promover repouso adequado aos animais e consequentemente impedir sobrecarga precoce no osso fraturado, mesmo após a osteossíntese.

Apesar dos efeitos terapêuticos comprovados do laser e ultrassom na promoção da osteogênese, pesquisas precisam ser realizadas para identificar as respostas biológicas do osso e a eficiência dos procedimentos clínicos em relação à associação de tecnologias. Uma revisão na literatura (LIRANI, 2004; RENNÓ et al., 2011; PRETEL; LIZARELLI \& RAMALHO, 2007; AL-HABIB et al., 2011) mostra que nenhum estudo investigou a 
associação sinérgica do LIPUS com o Laser no tratamento tardio de fraturas com atraso de consolidação óssea avaliada através de microtomografia por raios-X.

\subsection{Reparo ósseo de uma fratura}

A biologia do reparo ósseo foi detalhadamente descrita por Einhorn (2005) e por Marsell e Einhorn (2011). O reparo é normalmente bem sucedido, compreende uma série de processos celulares, moleculares e quatro tipos de tecidos: osso cortical, o periósteo, o tecido indiferenciado no entorno da fratura e a medula óssea (EINHORN, 2005), conforme a figura 15. As seguintes formas e etapas de reparo são descritas por esses autores:

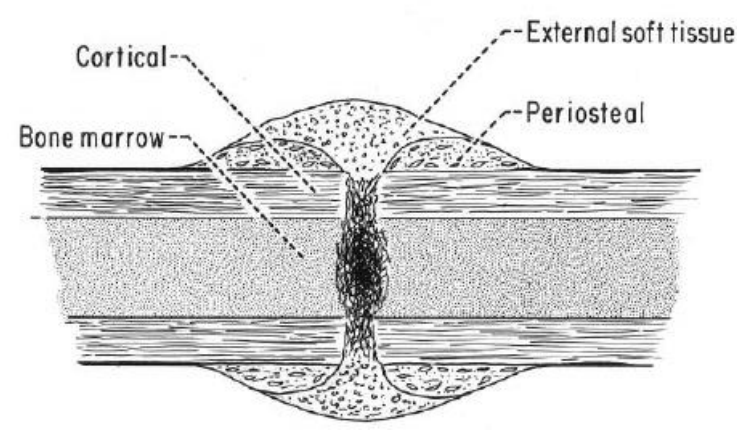

Figura 15 - Tecidos envolvidos no reparo de uma fratura óssea (EINHORN, 2005).

\subsubsection{Reparo Ósseo Indireto (Secundário)}

A forma indireta é a mais comum de reparo e nele ocorrem os eventos de formação óssea endocondral e intramembranosa. Não requer a redução anatômica da fratura e o uso de estabilização rígida, ao contrário, faz uso de micromovimentos e da carga do peso corporal (MARSELL \& EINHORN, 2011). Ainda, é conhecido que a movimentação excessiva e o uso de carga resulta em retardo de consolidação ou não-união (GREEN et al., 2005). O reparo indireto tipicamente ocorre em tratamentos de fraturas sem cirurgia ou em tratamentos cirúrgicos em que ocorre algum movimento no foco da fratura como os que utilizam haste intramedular, fixação externa ou uso de fixação interna em fraturas cominutivas (PAPE et al., 2002; PERREN, 2002). 


\subsubsection{A Resposta Inflamatória Aguda}

Após a ocorrência do trauma ocorre a formação de um hematoma com células sanguíneas periféricas, intramedulares e da medula óssea. Uma reação inflamatória é necessária para o reparo ósseo progredir. O hematoma coagula no interior e em volta das extremidades da fratura o que origina um arcabouço para a formação de um calo. Uma breve e altamente regulada secreção de moléculas pró-inflamatórias ocorre e representa uma etapa crítica para o reparo tecidual. A intensidade máxima da reação inflamatória é observada nas primeiras 24 h e é concluída em 7 dias, mas as moléculas pró-inflamatórias continuam a ter um desempenho importante nas etapas posteriores do reparo.

O processo inflamatório inicial envolve a secreção das moléculas fator de necrose tumoral $\alpha$ (TNF- $\alpha$ ), interleucinas (IL-1, IL-6, IL-11 e IL-18) que têm a função de recrutamento de células inflamatórias e a promoção de angiogênese. A concentração de TNF$\alpha$ atinge um pico em $24 \mathrm{~h}$ e volta ao seu valor normal em 72h (GERTENFELD et al., 2003). O TNF- $\alpha$ é secretado por macrófagos e outras células inflamatórias e se supõe que induza sinais inflamatórios secundários, além de atuar como agente quimiotático para recrutar células e invitro induz a diferenciação de células mesenquimais. Esses efeitos são mediados pelos fatores TNFR1 e TNFR2 que são expressos por osteoblastos e osteoclastos. O primeiro fator é sempre expresso no tecido ósseo, mas o segundo é expresso quando existe trauma. Acreditase que as interleucinas IL-1 e IL-5 sejam as mais importantes no reparo de fratura. A IL-1 é produzida por macrófagos na fase inflamatória aguda, induz a produção de IL-6 pelos osteblastos, promove a produção de calo cartilaginoso primário e promove a angiogênese no local da fratura pela ativação dos receptores IL-1RI ou IR-1RIL. O IL-6 é também produzido na fase aguda, estimula a angiogênese, a produção do fator de crescimento endotelial (VEGF) e a diferenciação de osteoblastos e osteoclastos.

\subsubsection{Recrutamento das Células Mesenquimais}

Para que ocorra a regeneração óssea é necessário o recrutamento, proliferação e diferenciação de células mesenquimais específicas. Acredita-se que estas células sejam originárias dos tecidos moles adjacentes, da medula óssea e de um recrutamento sistêmico. A proteína óssea morfogenética BMP-2 é importante no reparo, mas outras BMPs têm relevante função no recrutamento. 


\subsubsection{Produção de Calo Ósseo Cartilaginoso e Periostal}

Após a formação do hematoma primário forma-se um tecido de granulação rico em fibrina. Nesse tecido ocorre uma ossificação denominada endocondral, na região interna das extremidades da fratura e na região externa ao periósteo, caracterizada por um tecido macio cartilaginoso para dar estabilidade à fratura. Em modelos animais utilizando rato, coelho ou camundongo o pico dessa formação ocorre entre o $7^{\circ}$ e o $9^{\circ}$ dia após o trauma. Ao mesmo tempo uma ossificação denominada intramembranosa ocorre na região subperiostal e adjacente às extremidades distal e proximal da fratura resultando em um calo duro. A ponte de tecido formada neste calo duro e central forma uma estrutura semirrígida que permite a aplicação de carga corpórea.

A formação desses calos é dependente do recrutamento de células mesenquimais dos tecidos moles adjacentes, do córtex ósseo, periósteo, medula óssea e de uma ação sistêmica para recrutar células mesenquimais originárias de sítios hematopoiéticos. Inicia-se uma sucessão de eventos ou cascata molecular que envolve a produção de colágeno I e II e a participação de várias moleculas peptídicas sinalizadoras. Nesse processo, fatores transformadores de crescimento de $\beta$ (TGB- $\beta$ ), como TGB- $\beta 2$ e TGB- $\beta 3$ participam da ossificação endocondral enquanto as proteínas ósseas morfogenéticas (BMP), como BMP-5 e BMP-6 induzem a proliferação celular na ossificação intramembranosa que ocorre no periósteo. Como mencionado anteriormente, o BMP-2 tem função importante na inicialização das etapas de reparo ósseo. Em camundongos onde a formação de BMP-2 foi inibida não houve formação de calo ósseo.

\subsubsection{Revascularização e Angiogênese no Sítio da Fratura}

O reparo ósseo de uma fratura requer suprimento sanguíneo e a revascularização é essencial nesse processo. No reparo endocondral, isto é caracterizado como formação angiogênica, morte de condrócitos e degradação cartilaginosa, que caracterizam a remoção de células e matrizes extracelulares, para que ocorra a formação de vasos no sítio de reparo.

O processo de vascularização é essencialmente regulado por proteínas morfogenéticas vasculares denominadas angiopoitinas e por fatores de crescimento endotelial vascular (VEGF). A angiopoitina-1 e angiopoitina-2 são sintetizadas. A expressão destas proteínas é induzida no início do processo de reparo, sugerindo que promovam a formação vascular a 
partir de vasos existentes no periósteo. O fator VEGF desempenha a ação principal de regeneração vascular. Osteoblastos e condrócitos hipertróficos expressam altos níveis de VEGF, o que promove a invasão de vasos sanguíneos e a transformação da matriz cartilaginosa avascular em tecido ósseo vascularizado. Ações angiogênicas devem ocorrer devido ao sinergismo de BMPs com o VEGF.

\subsubsection{Mineralização e Reabsorção do Calo Cartilaginoso}

O progresso da regeneração depende da reabsorção do tecido primário e cartilaginoso que deve ser substituído por um calo ósseo e duro. Semelhantemente ao desenvolvimento ósseo embrionário, este processo é uma combinação de proliferação e diferenciação celular e aumento de volume celular e deposição da matriz. Uma família de moléculas denominadas Wnt tem ação relevante no processo embrionário e de regeneração (CHEN \& ALMAN, 2009). Investigações mostram que regulam a diferenciação de células mesenquimais pluripotentes em osteoblastos e nos estágios mais avançados de desenvolvimento regulam a formação óssea osteoblástica.

À medida que os condrócitos da fratura proliferam e tornam-se hipertróficos, a matriz extracelular se calcifica. Um processo em cascata está associado à reabsorção da cartilagem mineralizada com a presença das moléculas fator estimulador de colônia de macrófagos (MCSF), RANK-L existente na superfície de osteoblastos e que ativa a ação de osteoclastos, osteoprotegerina (OPG) e TNF- $\alpha$. A TNF- $\alpha$ promove o recrutamento de células mesenquimais com potencial osteogênico, bem como a apoptose dos condrócitos. As mitocôndrias atuam no mecanismo de liberação de cálcio pelos condrócitos, pois nela se acumulam grânulos ricos em cálcio que são transportados para a matriz extracelular onde se precipitam com fosfatos e formam depósitos de cristal de apatita. O pico de formação do calo duro em modelos animais ocorre no $14^{\circ}$ dia pós-trauma e pode ser monitorado por técnicas histomorfométricas de tecido mineralizado ou pela medida de marcadores como pró-colágeno I, osteocalcina, fosfatase alcalina e osteonectina.

\subsubsection{Remodelamento Ósseo}

O calo duro é uma estrutura rígida e garante estabilidade biomecânica, mas não apresenta todas as propriedades biomecânicas do tecido normal. Uma fase de reabsorção faz 
parte do reparo ósseo para remodelar o calo duro em uma estrutura lamelar com uma cavidade medular no centro (GERTENFEDL et al., 2003). Esta fase apresenta níveis altos de expressão de IL-1 e TNF- $\alpha$ e baixo nível de expressão da família TGF- $\beta$. Algumas moléculas BMPs, como BMP-2, apresentam níveis relativamente altos de expressão.

$\mathrm{Na}$ fase de remodelamento do calo duro observa-se uma ação de reabsorção dos osteoblastos e de deposição de osso lamelar dos osteoblastos. Em modelos animais e humanos observou-se que o remodelamento pode ter início em 3-4 semanas pós-trauma, mas pode durar anos para que a estrutura óssea seja plenamente reestabelecida. O processo deve ocorrer mais rápido em animais e pacientes jovens.

Basset (1971) mostrou que uma polaridade elétrica é criada quando a pressão é aplicada no tecido ósseo cristalino. Essa polarização origina-se no carregamento de ossos longos que origina uma superfície convexa eletropositiva e uma superfície convexa eletronegativa onde ocorrem ações osteoclásticas e osteoblásticas, respectivamente. Através dessas ações o calo é gradualmente transformado em osso lamelar e no osso interno é restabelecida a cavidade medular característica da diáfise óssea. O sucesso do remodelamento depende de suprimento sanguíneo e um aumento gradual da estabilidade mecânica (CARANO \& FILVAROFF, 2003).

\subsubsection{Reparo Ósseo Direto (Primário)}

O reparo direto não ocorre comumente no processo natural de reparo ósseo, pois requer uma redução anatômica correta das extremidades da fratura, sem a presença de intervalo ou espaço entre os mesmos e fixação estável. O principal objetivo ao se utilizar a cirurgia é a redução e fixação visando este tipo de reparo. O reparo ósseo primário pode ocorrer através de contato ou da existência de espaço entre as extremidades da fratura. Nos dois casos existe a intenção de restabelecer uma estrutura óssea lamelar anatomicamente corrigida e biomecanicamente competente.

\subsubsection{Reparo Ósseo com Contato}

O reparo direto com contato, só ocorre quando a restauração anatômica é obtida e uma fixação rígida é utilizada, resultando em um decréscimo significativo da deformação interfragmentária. O reparo por contato é caracterizado pela existência de um espaçamento 
menor que $0.01 \mathrm{~mm}$ e deformação inferior a $2 \%$. A união deve ocorrer ao nível do córtex das duas extremidades e reestabelecer o sistema haversiano na direção axial. Nessas condições formam-se canais orientados longitudinalmente (cutting cones) nas extremidades dos ósteons mais próximos da fratura. Nestes canais há osteoclastos que produzem cavidades com uma velocidade de $50-100 \mu \mathrm{m} / \mathrm{dia}$, que são ocupadas por osteoblastos. O processo resulta no restabelecimento do sistema haversiano que promove a penetração de vasos sanguíneos que carregam precursores de osteblastos e em reparo ósseo sem a existência de calo periostal.

\subsubsection{Reparo Ósseo com Espaçamento}

A existência de um espaçamento de $0.8 \mathrm{~mm}$ à $1 \mathrm{~mm}$ resulta que o reparo e o reestabelecimento do sistema haversiano não ocorrem simultaneamente. Neste processo a região fraturada é preenchida por osso lamelar orientado ao longo do eixo longitudinal que é gradualmente substituído por ósteons revascularizados que carregam células osteoprogenitoras que se diferenciam em osteoblastos e produzem mais osso lamelar em cada superfície dos fragmentos.

\subsubsection{Parâmetros morfométricos medidos por microtomografia por raio-X}

A microtomografia por raio-x $(\mu \mathrm{CT})$ possibilita o cálculo de parâmetros morfométricos 3D através dos voxels de um objeto e de parâmetros morfométricos 2D utilizando-se os pixels das seções binarizadas transversais, sagitais ou coronais. Os cálculos são realizados em regiões (ROI) ou volumes (VOI) de interesse. A ROI representa uma seção do objeto. Análises morfométricas 2D são realizadas nas ROIs selecionadas. A VOI é a reunião de ROIs contíguas que caracterizam um volume. Análises morfométricas 3D são realizadas através da VOI selecionada.

Em uma VOI selecionada é possível realizar um análise 2D utilizando-se as seções que compreendem a VOI. Esta análise representa um cálculo aproximado de uma análise 3D e o resultado é diferente de uma análise denominada de análise 3D direta ou verdadeira que utiliza o "modelo volumétrico renderizado de superficíe 3D" (Method Note - Bruker, 2012). Através dos softwares fornecidos pelos fabricantes de microtomógrafos, como o CT-Analyzer da Bruker (Bélgica), é possível a análise 3D direta ou 2D "seção por seção". 
A nomenclatura recomendada para os parâmetros morfométricos é discutida por Bouxsein et al. (2010). Os seguintes parâmetros, amplamente descritos na literatura sobre a qualidade óssea de osso trabecular, não se aplicam à avaliação do reparo ósseo em uma fratura: espessura da estrutura (St.Th), separação da estrutura (St.Sp), índice do modelo de estrutura (SMI) e grau de anisotropia (DA). A descrição de parâmetros relacionados à porosidade da estrutura trabecular é mais recente na literatura: número de poros fechados (Po.N(cl)), volume de poros fechados $(($ Po.v(cl)), superfície de poros fechados (Po.S(cl)), porcentagem de porosidade fechada $(\mathrm{Po}(\mathrm{cl}))$, volume de porosidade aberta (Po.V(op)), porcentagem de porosidade aberta (Po,(op)), volume total de poros (Po.V(tot)), e porcentagem total de porosidade (Po(tot)).

Salmon et.al. (2012) investigaram o uso da $\mu \mathrm{CT}$ no reparo ósseo utilizando os seguintes parâmetros: Volume do Tecido (TV), Volume Ósseo (BV), Porcentagem de Volume Ósseo (BV/TV), Fração Superfície Óssea/Volume Ósseo (BS/BV), Conectividade, Número de Euler, Fator Padrão de Osso Trabecular (Tb.Pf), Dimensão Fractal. As definições dos mesmos são a seguir descritas (Method Note - Bruker, 2012; CARBONARE et al., 2005; GENANT et al., 1998; HAHN et al., 1992; ODGAARD et al., 1993; FELDKAMP et al., 1989).

\section{a) Volume do Tecido $\left(\mathrm{TV}, \mathrm{mm}^{-3}\right)$}

É o volume total de tecido ósseo compreendido pela VOI.

Exemplo: uma fratura óssea compreende o tecido normal e o tecido de reparo que foi formado após o trauma.

\section{b) Volume Ósseo $\left(\mathrm{BV}, \mathrm{mm}^{-3}\right)$}

É o volume do tecido ósseo que está sendo analisado na VOI.

Exemplo: no reparo de uma fratura BV pode ser o volume do tecido normal ou do tecido de reparo que foi formado após o trauma.

\section{c) Porcentagem de Volume Ósseo (\%) \\ É o valor da fração BV/TV.}

\section{d) Fração Superfície Óssea/Volume Ósseo (BS/BV)}

Representa a complexidade da estrutura. Quanto menor o valor da fração maior é a complexidade. 
Nos poliedros com faces triangulares como o tetraedro (4 faces), octaedro ( 8 faces) e Icosaedro (20 faces) a fração superfície/volume diminui a medida que aumenta o número de faces.

\section{e) Conectividade $\left(\mathrm{mm}^{-3}\right)$}

É a medida do grau que representa como uma estrutura está multiplamente conectada sendo definida como o número máximo de ramificações que podem ser removidas antes de uma estrutura ser separada em partes. A conectividade é usualmente normalizada em relação ao volume do tecido (TV) que está sendo investigado e a unidade de medida é $1 / \mathrm{mm}^{3}$.

A figura 16A mostra uma estrutura simplesmente conectada caracterizada por nela existir um único caminho que conecta dois nós (P e Q). Se um ramo é adicionado alguns nós poderão ser conectados por mais de um caminho é a estrutura é denominada multiplamente conectada, conforme ilustrado na figura 16B. Em uma estrutura simplesmente conectada se um ramo é desconectado a estrutura será separada em partes isoladas. $\mathrm{Na}$ estrutura multiplamente conectada alguns ramos precisarão ser desconectados para que a estrutura seja separada em partes.

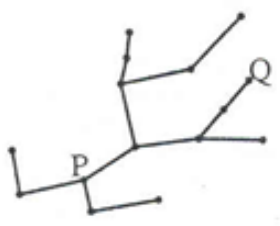

(A)

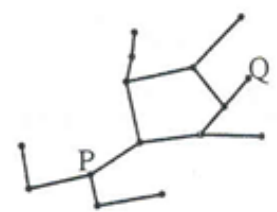

(B)

Figura 16 - Estrutura simplesmente conectada (A) e multiplamente conectada (B) (ODGAARD \& GUNDERSEN, 1993).

Diferentes medidas da connectividade são descritas na literatura (ODGAARD \& GUNDERSEN, 1993; ROQUE et al., 2013). As medidas de interesse nesta investigação são descritas a seguir:

\section{- $\quad$ Número de Euler (Eu.N)}

É um parâmetro topológico que quantifica a conectividade em 3D. O Número de Euler é expresso pelo número de nós (n) e de ramos (b) de uma estrutura 3D por Eu.N = n-b. No caso de uma estrutura onde existe pelo menos um caminho entre dois nós a quantidade 1-Eu.N representa o número máximos de ramos que podem ser removidos sem separar em partes a estrutura (FELDKAMP et al., 1989). Em uma estrutura altamente conectada, como o 
osso trabecular saudável, Eu.N apresenta valores altos e negativos. Um osso severamente osteoporótico tem valores baixos e negativos.

Na literatura é descrito o conceito de um corpo convexo como sendo um corpo no qual qualquer segmento contendo dois pontos internos do seu interior está contido no seu interior (b.cube (7/10/13)), conforme ilustrado na figura 17.
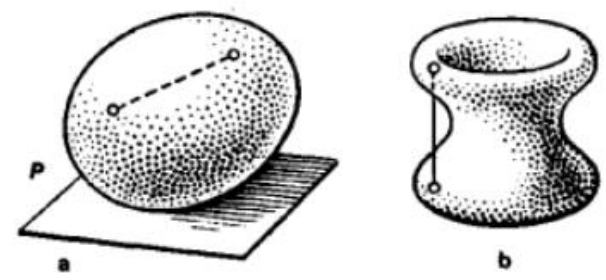

Figura 17 - Ilustração de um corpo convexo (a) e não-convexo (b) (Encyclopedia, 7/10/13).

Em topologia (ODGAARD \& GUNDERSEN, 1993) demonstra-se que um corpo 3D qualquer pode ser decomposto em corpos convexos e que o parâmetro topológico Número de Euler (Eu.N) pode ser expresso pela equação (9) sendo $\beta_{0}$ o número de partículas não conectadas, $\beta_{1}$ o número de conexões e $\beta_{2}$ o número de cavidades fechadas. Para o osso trabecular mostra-se que $\beta_{\mathrm{o}}=1$ e $\beta_{2}=0$ e a equação (9) apresenta a forma simplificada (10).

$$
\begin{aligned}
& \text { Eu.N }=\beta_{0}-\beta_{1}+\beta_{2} \\
& \text { Eu.N }=1-\beta_{1}
\end{aligned}
$$

\section{- $\quad$ Conectividade de Euler (Conn)}

A conectividade de Euler (Conn) é uma medida da conectividade de uma estrutura sendo definida como Conn $=\beta_{1}=1-$ Eu.N.

\section{- $\quad$ Densidade de Conectividade de Euler (Conn.D)}

A Conn.D é a connectividade de Euler dividida pelo volume do objeto (TV), isto é, Conn.D $=(1-$ Eu.N $) /$ TV.

\section{f) Fator Padrão de Osso Trabecular (Tb.Pf $\left.\mathbf{~ m m}^{-1}\right)$}

É uma medida da relação entre os elementos côncavos e convexos de uma estrutura. Em estruturas bem conectadas as superfícies côncavas são abundantes enquanto que nas 
desconectadas as superfícies convexas são abundantes. A concavidade expressa a conectividade da estrutura. Hahn e colaboradores (1992) propuseram uma medida de conectividade 2D denominada fator padrão de osso trabecular (Tb.Pf).

Na figura 18 está esquematizada uma figura com superfície convexa (A) e côncava (B), respectivamente.

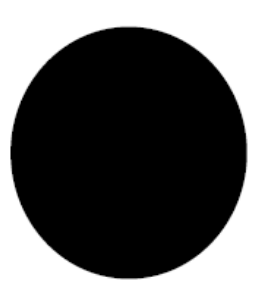

(a)

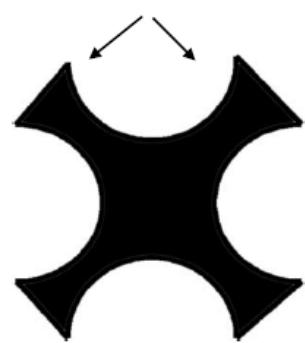

(b)

Figura 18 - Representação do conceito do fator padrão de osso trabecular. Em (A) superfície convexa e em (B) superfície côncava com as setas indicando os ramos de conexão (CARBONARE et al., 2005).

A figura 19 ilustra a técnica 2D de processamento de imagem denominada de dilatação, que permite determinar o parâmetro Tb.Pf (HAHN et al., 1992). Em uma estrutura convexa a dilatação aumenta a área e o perímetro do tecido. Em uma estrutura côncava a dilatação aumenta a área, mas diminui o perímetro do tecido. O Tb.Pf é definido como o quociente Tb.Pf $=\left(\mathrm{P}_{1}-\mathrm{P}_{2}\right) /\left(\mathrm{A}_{1}-\mathrm{A}_{2}\right)$ onde $\mathrm{P}_{1}$ e $\mathrm{A}_{1}$ são as medidas antes da dilatação e $\mathrm{P}_{2} \mathrm{e}$ $\mathrm{A}_{2}$ as medidas após a dilatação. Devido a diminuição do perímetro ósseo em superfícies côncavas o Tb.Pf pode ser negativo. Na medida 3D de Tb.Pf as variáveis da área e do perímetro são substituídas por superfície e volume, isto é, Tb.Pf $=\left(S_{1}-S_{2}\right) /\left(V_{1}-V_{2}\right)$. Em 3D o Tb.Pf compara a superfície e o volume de um sólido antes e depois da dilatação dos voxels do objeto (Morphometric Parameters Measured by SkyScan CT-Analyser Software, 2013).

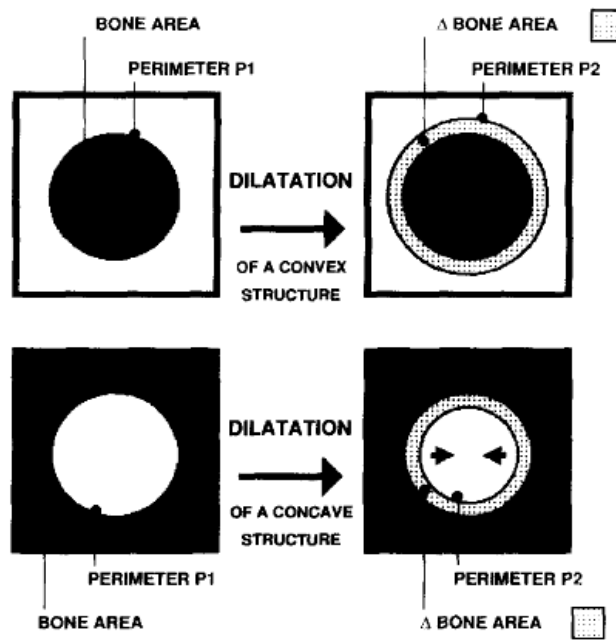

Figura 19 - Procedimento de dilatação em uma estrutura convexa (acima) e côncava (abaixo) (HAHN et al., 1992). 
Quando uma estrutura óssea trabecular é altamente desconectada as superfícies convexas são predominantes (alto valor de Tb.Pf). Quando uma estrutura óssea trabecular é altamente conectada as superfícies côncavas são predominantes (baixo valor de Tb.Pf).

\section{g) Dimensão Fractal (FD)}

A dimensão fractal é um indicador da complexidade da superfície de um objeto que pode ser utilizada para se quantificar como aquela superfície ocupa o espaço. A figura 20 exemplifica imagens 2D cuja forma complexa não é descrita por geometria euclidiana. $\mathrm{O}$ matemático francês Benoit Mandelbrot formalizou uma geometria denominada fractal para descrever formas complexas (MANDELBROT, 1982). Uma propriedade básica de uma imagem fractal é a noção de auto-similaridade. Um exemplo típico é folha de samambaia no qual cada ramo é muito parecido com a folha inteira.

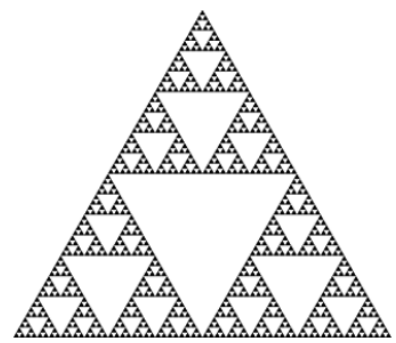

(a)

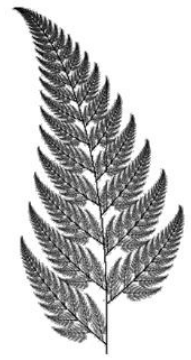

(b)

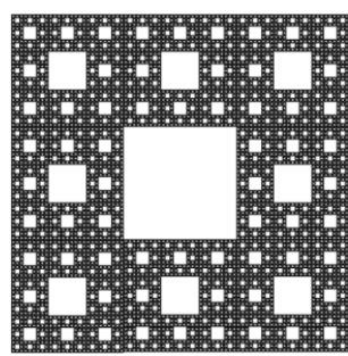

(c)

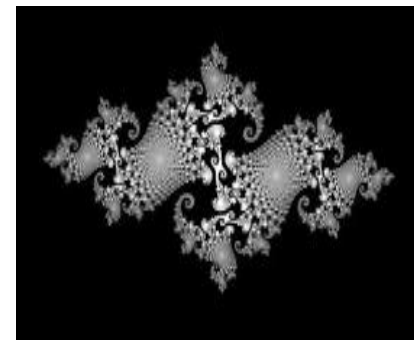

(d)

Figura 20: Estruturas fractais: (a) triângulo de Sierpinski, (b) folha de samambaia, (c) carpete de Sierpinski, (d) Julia (Fractals,Fractal Dimension, Fractal in Nature, 8/10/13).

O osso trabecular possui uma estrutura 3D complexa. A microarquitetura se altera com mudanças biomecânicas, metabólicas e com a idade (CHAPPARD et al., 2001). Várias investigações avaliaram as características da estrutura trabecular utilizando cortes histológicos (COMPSTON et al., 1987; CHAPPARD et al., 1988; CROUCHER et al., 1996) ou imagens de tomografia e ressonância magnética (SIMMONS \& HIPP, 1997).

A dimensão fractal (FD) é um parâmetro útil para descrever a arquitetura trabecular e a sua correlação com propriedades biomecânicas tem sido investigada. Em um estudo envolvendo o uso de amostras cúbicas trabeculares de $15 \mathrm{~mm}$ extraídas do metacarpo de equinos o módulo de Young foi medido nas três direções perpendiculares. Um dos procedimentos experimentais foi a mensuração da dimensão fractal nas duas faces das amostras normais à direção do carregamento durante o ensaio mecânico. Observou-se uma 
correlação linear positiva entre o módulo de Young e a média da dimensão fractal medida nas duas faces (HAIRE et al., 1998).

Diferentes medidas 2D da FD em osso trabecular estão descritas na literatura (CHAPPARD et al., 2001). Um das medidas 2D mais comumente utilizada é a técnica de contagem de quadrados, ilustrada na figura 21. Uma grade com quadrados é superposta a imagem 2D. Conta-se o número de quadrados onde existem trabéculas ósseas $(\mathrm{N}(\varepsilon))$, sendo $\varepsilon$ a dimensão do lado do quadrado. Ao se plotar o gráfico $\log \mathrm{N}(\varepsilon) \times \log \varepsilon$ observa-se uma curva decrescente com uma região linear. A medida da inclinação da região linear é denominada de dimensão fractal da imagem. A medida de parâmetros topológicos da arquitetura trabecular da FD é descrita na literatura (SAHA; GOMBERG \& WEHRLI, 2000). A medida em 3D da FD pela técnica de contagem utiliza uma grade 3D.
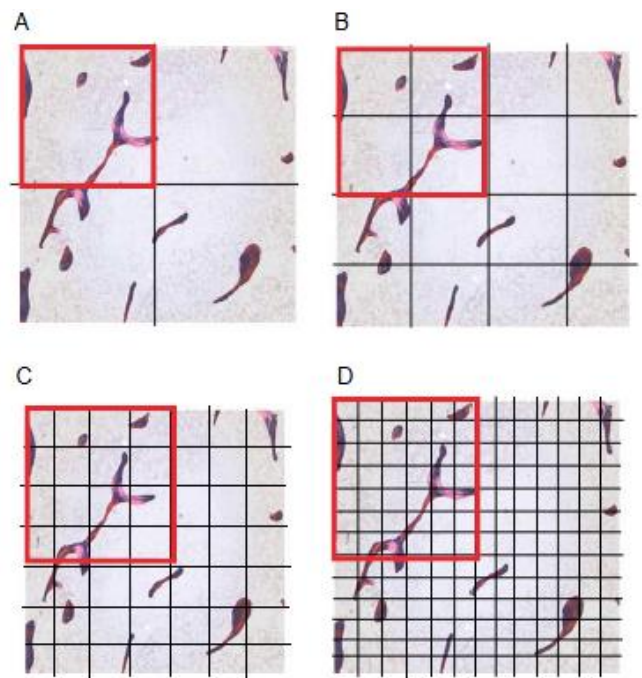

Figura 21 - Técnica de contagem de quadrados para a medida da dimensão fractal (CARBONARE et al., 2005).

Uma medida 3D da dimensão fractal é realizada por softwares fornecidos pelos fabricantes de microtomógrafos com o CT-Analyzer da Bruker (Bélgica). A medida da FD foi utilizada para a quantificação do reparo ósseo de fraturas produzidas em ratos considerandose o tecido neoformado (ou de reparo) e o tecido ósseo existente antes da fratura (SALMON et al., 2012). Os autores relatam que o decréscimo observado da FD está relacionado com o decréscimo da complexidade do tecido ósseo e a um tecido de reparo de menor volume e menos poroso.

Neste contexto, dois estudos foram utilizados nesta investigação como referências bibliográficas metodológicas sobre o uso da microtomografia por raio-x $(\mu \mathrm{CT})$ para o reparo de fratura. 
No primeiro estudo Morgan et al. (2009) analisaram as mudanças na estrutura e composição do calo de uma fratura como indicativo das propriedades mecânicas. A $\mu \mathrm{CT}$ e testes de torção foram utilizados para a avaliação do calo da fratura, produzida por impacto (EINHORN, 1984), no fêmur de 188 ratos em diferentes estágios do reparo e em diferentes condições que afetaram o reparo. Foi quantificado o volume total do calo (TV), o volume do calo mineralizado (BV), a fração de volume do calo mineralizado (BV/TV), o conteúdo mineral ósseo (BMC), a densidade mineral do tecido (TMD), o momento de inércia polar efetivo do calo ( $\mathrm{I}_{\mathrm{eff}}$ ), a resistência à torção e a rigidez à torção (módulo de torção). Esses parâmetros de resistência mecânica, utilizando-se métodos estatísticos multivariáveis, foram dependentes da TMD e BV. O escaneamento dos fêmures foi realizado em um microtomógrafo Scanco (Suíça) modelo $\mu$ CT40 com uma resolução de $12 \mu \mathrm{m}$. A figura 22A mostra o calo segmentado compreendendo a região entre a linha verde e a linha vermelha (córtex periostal). Nas figuras 22B e 22C observa-se a reconstrução 3D e uma seção longitudinal, respectivamente. Imagens com 16 bits de tons de cinza das seções do osso fraturado foram utilizadas nos algoritmos de imagem para a separação do calo do tecido ósseo normal.
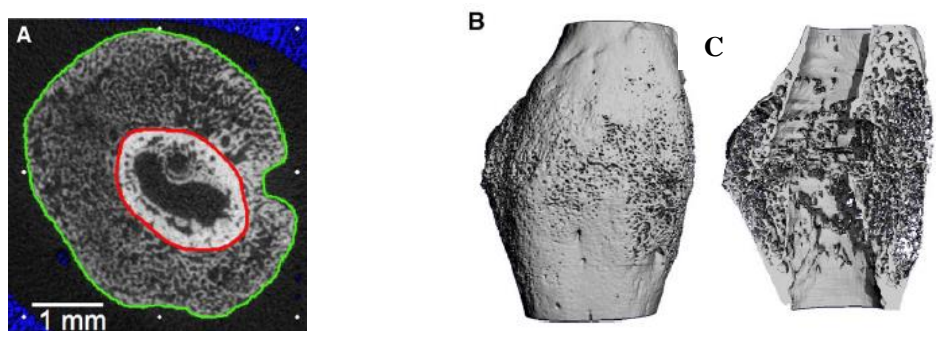

Figura 22 - Isolamento do calo ósseo em fratura de fêmur utilizando-se $\mu \mathrm{CT}$ e resolução de $12 \mu \mathrm{m}$ (MORGAN et al., 2009).

No segundo estudo Salmon et al. (2012) analisaram o calo ósseo formado em fraturas na diáfise do fêmur de 27 ratos utilizando-se a técnica de Einhorn. Os animais foram sacrificados na $2^{\mathrm{a}}, 4^{\mathrm{a}}$ e $6^{\mathrm{a}}$ semanas após a fratura. Os fêmures foram excisados e mantidos em solução tampão de formol até serem escaneados com resolução de $28 \mu \mathrm{m}$ em microtomógrafo modelo 1172 da SkyScan (Bélgica). Imagens com 8 bits de tons de cinza das seções do osso fraturado foram utilizadas nos algoritmos de imagem para a separação do calo do tecido ósseo normal. As imagens 23A e 23B mostram uma das seções transversais do calo da fratura. Em A o calo é mostrado em vermelho e em B observa-se a imagem digitalizada onde o calo e o tecido normal estão claramente separados. 

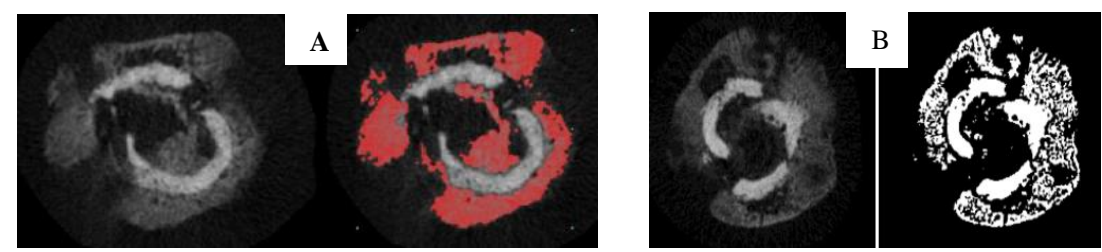

Figura 23 - Isolamento do calo ósseo em fratura de fêmur utilizando-se $\mu \mathrm{CT}$ e resolução de $28 \mu \mathrm{m}$ (SALMON et al., 2012).

No estudo de Salmon e colaboradores (2012) foram realizadas três análises: a) tecido mineralizado presente na região do reparo ósseo; b) tecido não mineralizado presente na região do reparo ósseo; c) tecido normal em conjunto com o calo. Os seguintes parâmetros foram comparados nos tecidos existentes na $2^{\mathrm{a}} .4^{\mathrm{a}}$ e $6^{\mathrm{a}}$ semana: volume do calo (BV), relação BS/VS, densidade de conectividade (Conn.D.), dimensão fractal (FD) e fator padrão trabecular (Tb.Pf). Na análise do tecido normal em conjunto com o calo observou-se uma diminuição significativa do BV e do FD na $6^{\mathrm{a}}$ semana após o trauma.

Assim, a microtomografia por raio-x permite o acompanhamento do processo de reparo ósseo, fornecendo características estruturais e mecânicas, das alterações decorrentes de intervenções terapêuticas, como a utilização de US e Laser para favorecer a consolidação óssea. 


\section{OBJETIVO}

O objetivo deste estudo consistiu em avaliar os efeitos do ultrassom de baixa intensidade (LIPUS) e do laser de baixa potência (LLLT), individualmente e associados, nas características morfométricas e topológicas do reparo ósseo em osteotomias completas em tíbia de ratos com atraso na consolidação induzido pelo uso de espaçador polimérico utilizando como técnicas de avaliação a microtomografia por raio-x e a histomorfometria. 


\section{MATERIAL E MÉTODOS}

Os procedimentos experimentais com os animais foram aprovados pelo "Comitê de Ética em Experimentação Animal” da Universidade Federal de São Carlos (UFSCar), conforme Parecer $n^{\circ}$. 050/2011 (Anexo A). O estudo foi realizado de acordo com os princípios éticos para prática didático-científica da vivisseção de animais, conforme a Lei Federal 11.794 de 08 de outubro de 2008.

\subsection{Animais}

Foram utilizados 50 ratos machos da linhagem Wistar (sendo 2 utilizados no estudo piloto) com peso corporal médio entre 400 e 500 gramas (g). A fratura no terço médio da tíbia com retardo de consolidação foi induzido com sucesso em 24 animais. Os animais excluídos do estudo tiveram deslocamento do material para estabilização da fratura (fio de Kirschner) e/ou do espaçador entre os fragmentos ósseos no período pós-cirúrgico. Os animais foram alojados no Biotério do Laboratório de Bioengenharia da Escola de Engenharia de São Carlos da Universidade de São Paulo (USP) em ambiente controlado (ciclo claro/escuro 12/12 horas), higienizado e temperatura controlada de $24 \pm 2{ }^{\circ} \mathrm{C}$. Todos os animais foram mantidos individualmente em gaiolas de polipropileno padrão, alimentados com ração comercial e água à vontade (Figura 24).

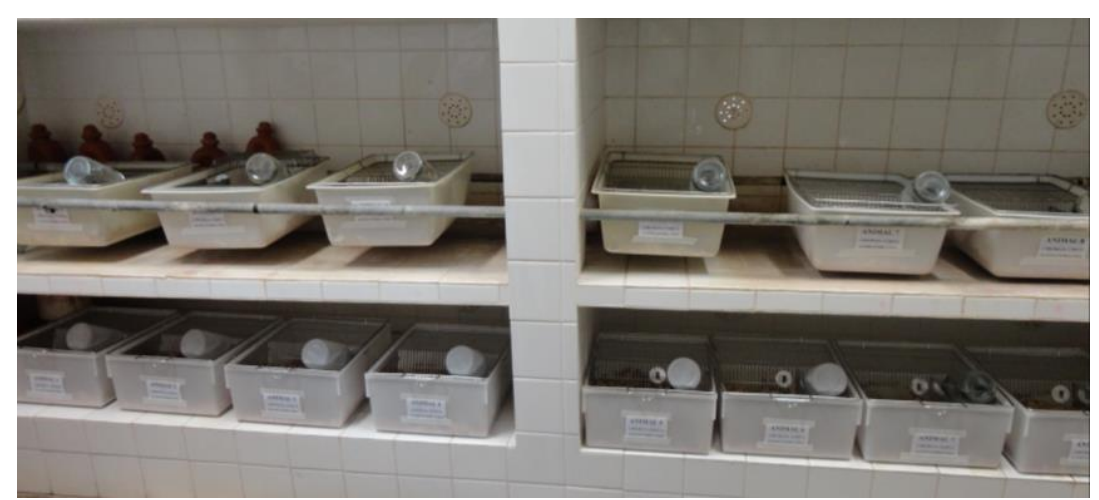

Figura 24 - Imagem parcial do Biotério. 
Os animais foram separados aleatoriamente em 4 grupos:

- Grupo Controle: osteotomia total com fixação com fio de Kirschner, intervalo de $2 \mathrm{~mm}$ entre os fragmentos proximal e distal para induzir retardo de consolidação, sem tratamento por LIPUS e/ou Laser de baixa potência $(n=5)$.

- Grupo Laser: osteotomia total com fixação com fio de Kirschner, intervalo de $2 \mathrm{~mm}$ entre os fragmentos proximal e distal para induzir retardo de consolidação, com tratamento por Laser de baixa potência $(n=6)$.

- Grupo US: osteotomia total com fixação com fio de Kirschner, intervalo de $2 \mathrm{~mm}$ entre os fragmentos proximal e distal para induzir retardo de consolidação, com tratamento por LIPUS $(n=6)$.

- Grupo US + Laser: osteotomia total com fixação com fio de Kirschner, intervalo de $2 \mathrm{~mm}$ entre os fragmentos proximal e distal para induzir retardo de consolidação, com tratamento por LIPUS associado ao Laser $(n=7)$.

\subsection{Procedimento cirúrgico: indução do retardo de consolidação}

Os animais foram pesados e posteriormente anestesiados de acordo com a massa corporal. Utilizou-se uma combinação a base de cloridrato de ketamina 10\% (Ketamina®, Agener União, Brasília, Brasil) $(80 \mathrm{mg} / \mathrm{Kg})$ e cloridrato de xilazina $2 \%$ (Rompum ${ }^{\circledR}$, Bayer AG, Leverkusen, Alemanha) (12 mg/Kg) que foi aplicada com injeção intramuscular. Em seguida, foram realizadas a tricotomia e assepsia da pele que recobre o músculo e o osso tibial para iniciar o procedimento cirúrgico.

O modelo de atraso na consolidação utilizado nessa pesquisa foi fundamentado pelo estudo de Miles et al. (2011) (figura 25).

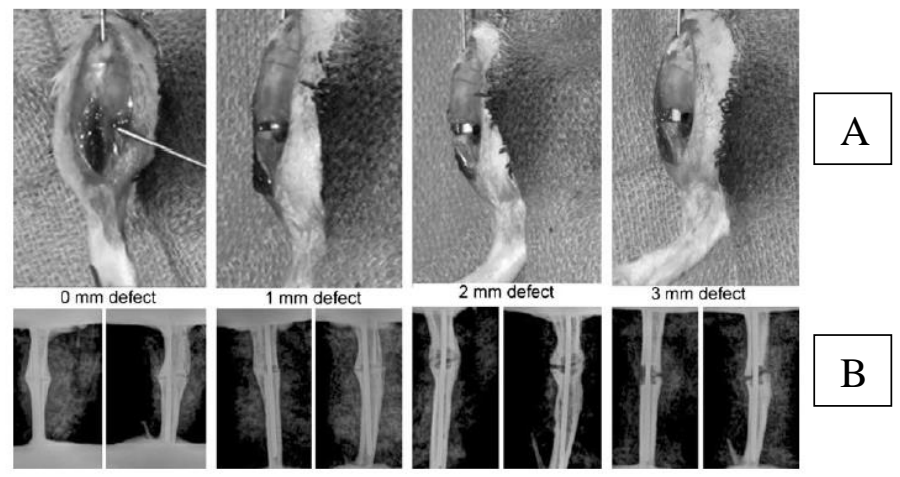

Figura 25 - Imagens pós-cirúrgicas (A) e radiográficas $(\mathrm{B})$ de tibias de rato submetidas à osteotomia total com uso intramedular de fio de Kirschner na ausência de espaçador polimérico $(0 \mathrm{~mm})$ ou na presença de espaçador polimérico para induzir reparo ósseo normal, retardo de consolidação ou não-união com espaçadores de espessura de $1 \mathrm{~mm}, 2 \mathrm{~mm}, 3 \mathrm{~mm}$, respectivamente (MILES et al., 2011). 
Uma incisão longitudinal de aproximadamente $2 \mathrm{~cm}$ foi realizada sobre a superfície anterior da tíbia direita abaixo da articulação do joelho. Os músculos foram afastados com pinça para permitir a exposição da região antero-medial superior da tíbia para realização da osteotomia. Para identificar o local da osteotomia foi utilizada como referência a inserção dos músculos isquiotibiais (na tíbia), que corresponde à junção dos terços proximal e médio da tíbia.

As fraturas foram obtidas por meio de osteotomias totais e transversais (Figura 26) utilizando um aparelho de serra dentada rotativa da marca Driller K® modelo BLM 600 plus, com caneta de alta rotação com fresa de $1 \mathrm{~mm}$ de diâmetro e $690 \mathrm{rpm}$. A área foi irrigada constantemente com soro fisiológico para evitar queimadura do tecido ósseo. A fratura foi estabilizada com o Fio de Kirschner ( $0,89 \mathrm{~mm}$ diâmetro) e um espaçador polimérico de $2 \mathrm{~mm}$ de espessura e $1 \mathrm{~mm}$ de diâmetro interno que foi colocado no local da osteotomia (Figura 26) para induzir o atraso na consolidação. O espaçador era transparente (Figura 27) para minimizar alterações na reflexão, transmitância, absorbância e espalhamento da radiação por laser. Após a realização da osteotomia, os músculos foram reaproximados, a pele foi suturada com fio de náilon monofilamentar 4.0 e foi feita a limpeza local.

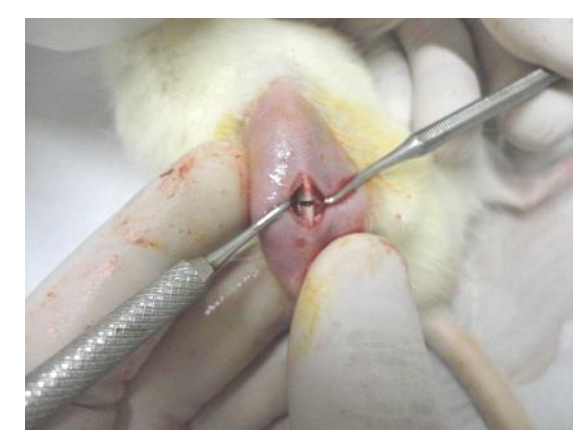

Figura 26 - Osteotomia completa.

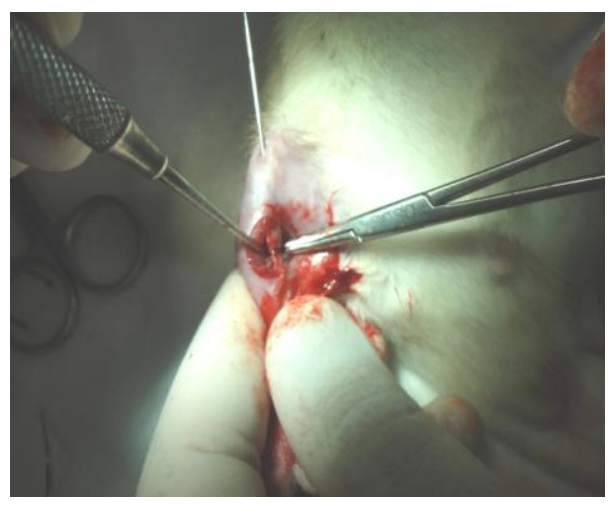

Figura 27 - Introdução do fio de Kirschner e do espaçador polimérico 


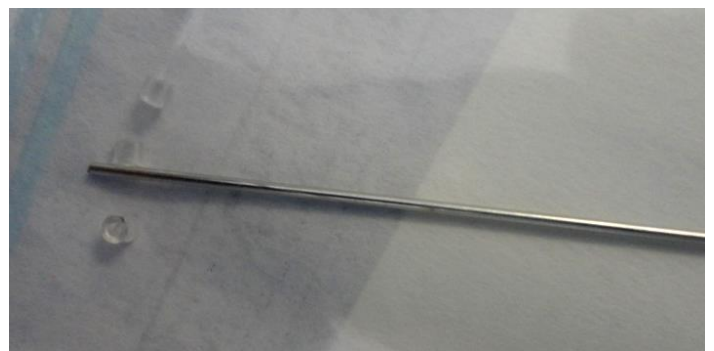

Figura 28 - Espaçadores transparentes e fio de Kirschner, na embalagem, após esterilização por óxido de etileno.

Os tratamentos com Laser e/ou LIPUS foram iniciados após cinco semanas da cirurgia (42 dia pós-cirúrgico), pois de acordo com o modelo experimental de Miles et al. (2011) o atraso na consolidação está presente nesse período.

O fluxograma do procedimento experimental pode ser visualizado na linha do tempo, conforme a Figura 29.

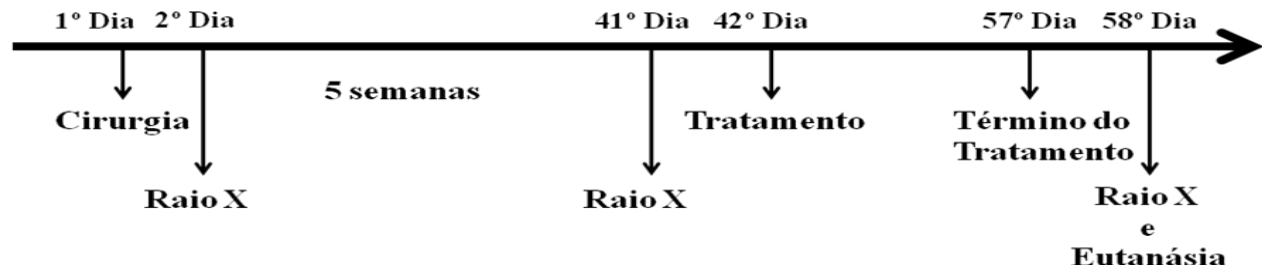

Figura 29 - Linha do tempo.

\subsection{Raio-x}

Imagens radiográficas foram realizadas 24 horas após o procedimento cirúrgico e antes do início do tratamento, para constatar a não consolidação da fratura. Foram realizadas também após 24 horas do término do tratamento que se refere ao período que antecede a eutanásia dos animais. O procedimento laboratorial para o registro radiográfico pode ser visualizado na Figura 30 e o controle da evolução da consolidação da fratura são ilustrados na tabela 4 para dois animais de cada grupo experimental.
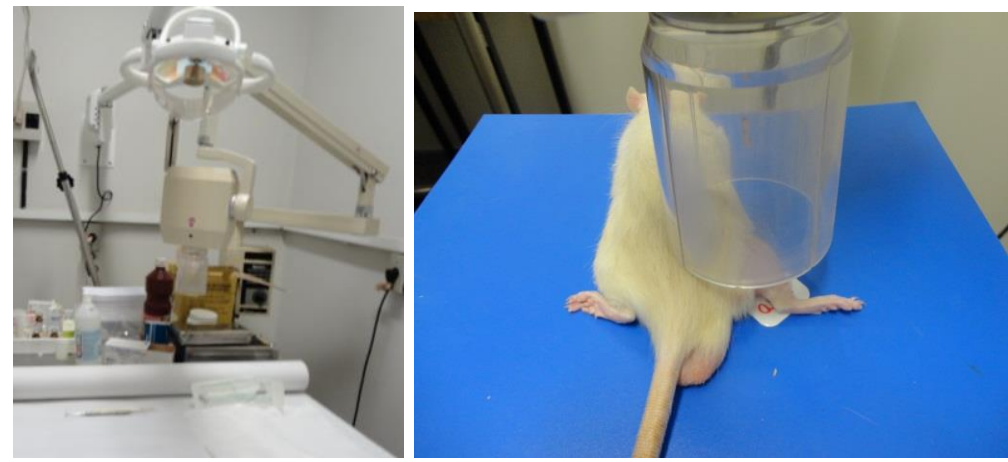

Figura 30: Procedimento laboratorial do registro das imagens por raio-X. 
Tabela 4 - Controle radiográfico da evolução da consolidação da fratura nos animais

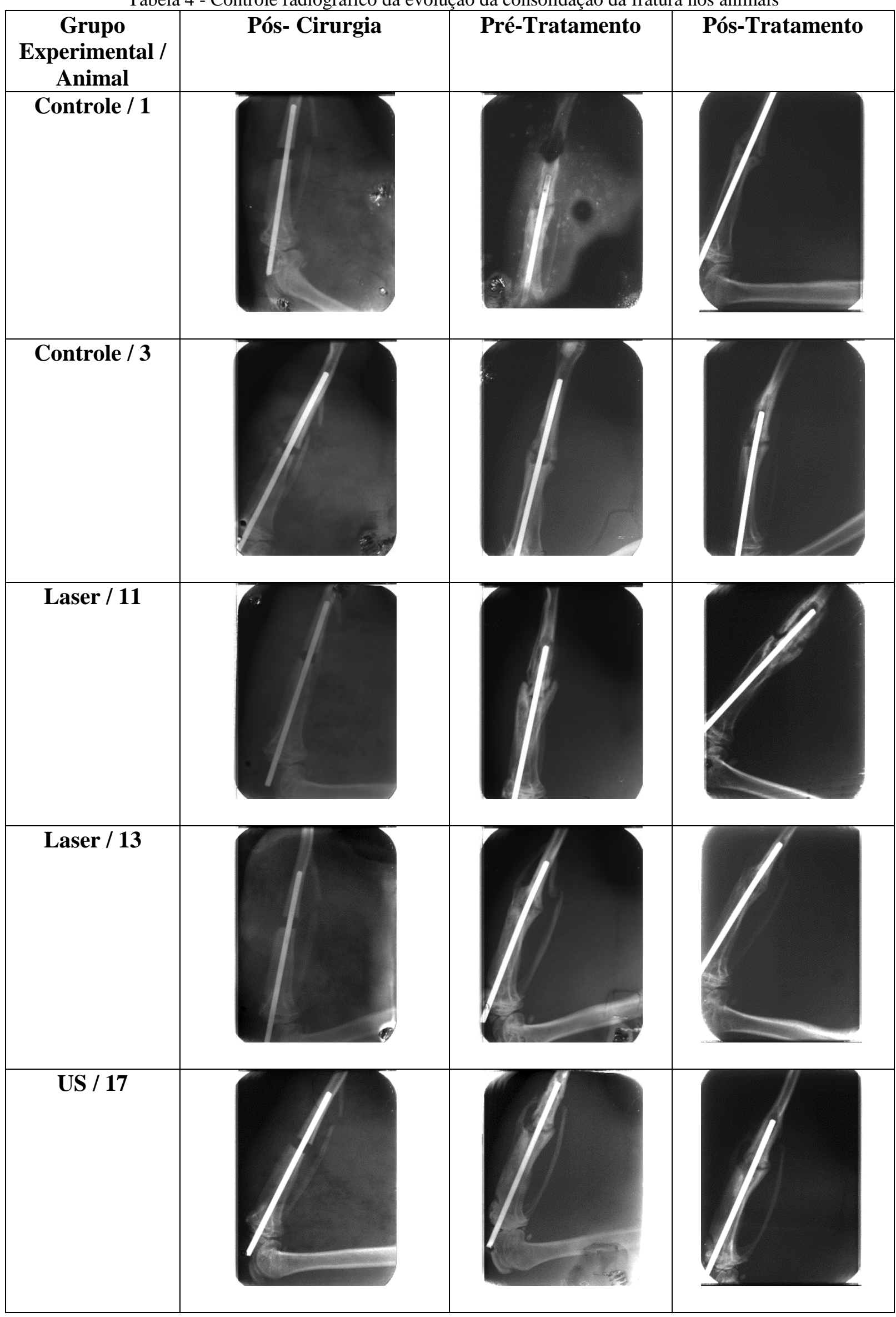


Tabela 4 (cont.) - Controle radiográfico da evolução da consolidação da fratura nos animais

\begin{tabular}{|c|c|c|c|}
\hline $\begin{array}{c}\text { Grupo } \\
\text { Experimental / } \\
\text { Animal }\end{array}$ & Pós- Cirurgia & Pré-Tratamento & Pós-Tratamento \\
\hline US / 18 & & & \\
\hline US + L / 26 & & & \\
\hline US + L / 27 & & & \\
\hline
\end{tabular}

\subsection{Tratamento}

Após cinco semanas do procedimento cirúrgico, com ausência de consolidação da fratura comprovada por raio-x, os tratamentos foram iniciados. A periodicidade e frequência do tratamento foram fundamentadas pelo estudo de Lirani-Galvão et al. (2006). As aplicações de Laser e/ou LIPUS foram realizadas durante cinco dias consecutivos de tratamento, seguidos por dois dias sem serem tratados até totalizarem 12 sessões terapêuticas. Os animais do grupo controle não receberam nenhum tipo de tratamento. 


\subsubsection{Tratamento com Laser}

Para laserterapia foi utilizado o Laser Arsenieto de Gálio e Alumínio (As-Ga-Al) modelo Twin Laser® (MM Optics, São Carlos, SP, Brasil), infravermelho (808 nm) com 0,04 $\mathrm{cm}^{2}$ de área do feixe e luz guia vermelha. Para dosimetria foi mensurada a potência em miliwatt utilizando-se um potenciômetro (Coherent Inc., Santa Clara, CA, USA) e um fotodetector com área de $2.54 \mathrm{~cm}^{2}$. A fórmula utilizada foi a tradicional na fototerapia: Dose $\left(\mathrm{J} / \mathrm{cm}^{2}\right)=$ Potência $(\mathrm{W}) \times$ Tempo $(\mathrm{s}) /$ Área $\left(\mathrm{cm}^{2}\right)$. Os parâmetros de irradiação foram fundamentados nos estudos de Bossini et al. (2012), Oliveira et al. (2011) e Rennó et al. (2006). Foi utilizado o Laser no modo contínuo com $100 \mathrm{~mW}$ de potência, $2500 \mathrm{~mW} / \mathrm{cm}^{2}$ de intensidade, durante 50 segundos, que conduziu a uma dose de $125 \mathrm{~J} / \mathrm{cm}^{2}$. A aplicação foi realizada pela técnica pontual e modo contato, somente sobre a fratura (1 ponto), sendo a ponteira do equipamento posicionada perpendicularmente ao local tricotomizado $\left(90^{\circ}\right)$ para que não ocorresse perda de energia (Figura 31).
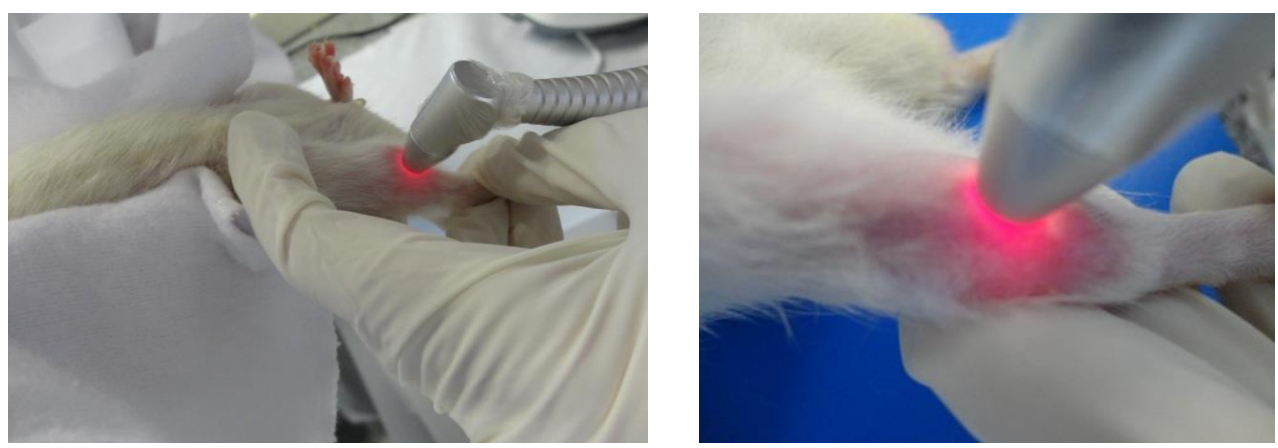

Figura 31 - Tratamento com laser.

\subsubsection{Tratamento com ultrassom (LIPUS)}

Foi utilizado o US Exogen® Bone Healing System (Exogen, Inc., Piscataway, NJ, USA) que transmite ultrassom pulsado de baixa intensidade com frequência de 1,5 MHz, ciclo de trabalho 1:4 e intensidade SATA de $30 \mathrm{~mW} / \mathrm{cm}^{2}$ e tempo de aplicação de 20 minutos com gel sobre a pele tricotomizada na região fraturada em modo estacionário (Figura 32). Estes parâmetros são amplamente utilizados por diversos estudos (OLIVEIRA et al., 2011; LIRANI-GALVÃO et al., 2006; OKADA et al., 2003). A dosimetria do equipamento de US foi realizada utilizando-se uma balança de radiação acústica Ultrasound Power Meter UPMDT-1 (Ohmic Instruments, EUA). Ainda, para se evitar o uso de anestésico, os animais foram mantidos em uma caixa de madeira com entrada de ar e iluminação. 

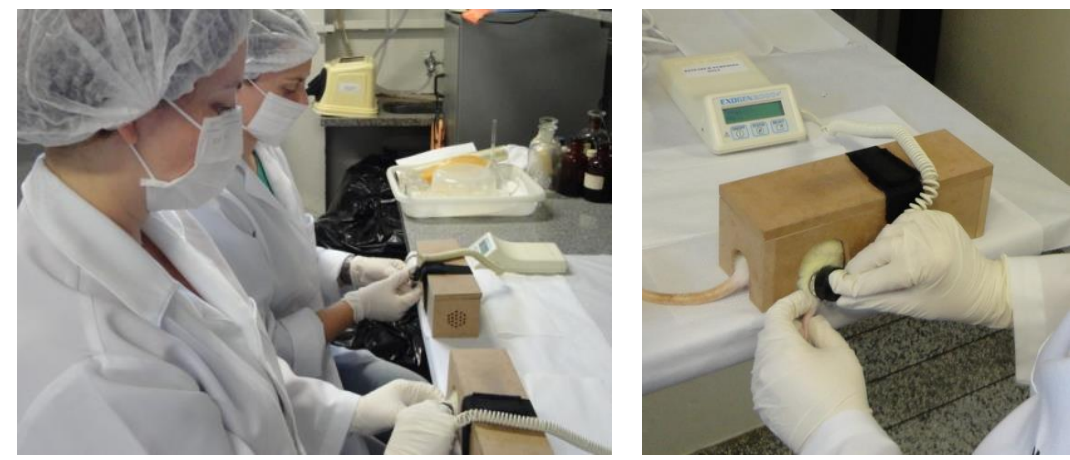

Figura 32 - Tratamento com LIPUS.

\subsection{Tratamento com laser associado ao ultrassom}

Para associar o tratamento do Laser e LIPUS pulsado iniciou-se a sessão com a aplicação do LIPUS. No décimo minuto foi realizada simultaneamente a aplicação de Laser durante 50 segundos e a aplicação de US prosseguiu até o $20^{\circ}$ minuto, sem interrupção. O laser foi aplicado perpendicularmente ao US (Figura 33) como realizado no estudo de AlHabib et al. (2011) para interação fotoacústica.

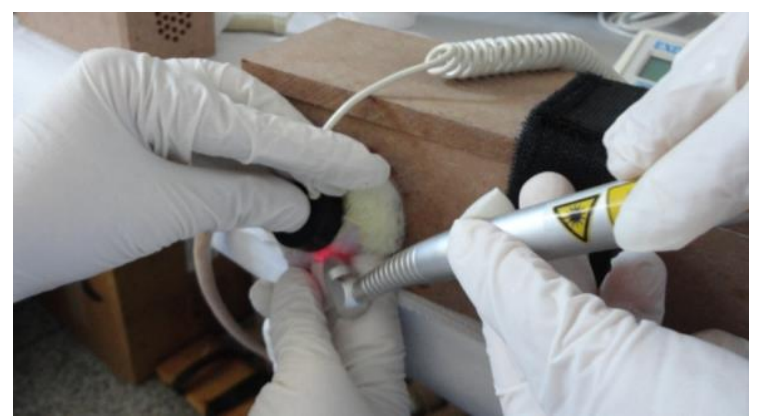

Figura 33 - Tratamento com associação de Laser e LIPUS.

\subsection{Eutanásia e coleta das amostras}

A eutanásia dos animais ocorreu por meio de overdose de anestésico após 24 horas da última sessão terapêutica (58 dias do procedimento cirúrgico). Após a eutanásia foi realizada a ressecção cirúrgica completa da tíbia direita, que foi armazenada com gaze banhada em solução salina e congelada à $-20^{\circ} \mathrm{C}$. Precedendo a realização das avaliações microtomográfica e histomorfométrica as amostras foram fixadas em formalina $10 \%$. 


\subsection{Avaliação Radiográfica Cega}

A avaliação radiográfica cega do reparo ósseo das imagens foi realizada a partir da reconstrução microtomografica $3 \mathrm{D}$, realizada por um médico ortopedista, para constatar a presença ou ausência de consolidação. O grau de reparo ósseo foi classificado com escore de 0 a 4, sendo 0 ausência de consolidação e 4 consolidação completa.

\subsection{Microtomografia por Raio-X}

A aquisição das projeções e a reconstrução das amostras foram realizadas pelo microtomógrafo de raio-x (modelo 1172, SkyScan, Bélgica) da Faculdade de Odontologia da USP - FORP (Ribeirão Preto - SP) (Figura 34) sendo utilizados os seguintes parâmetros para o escaneamento microtomográfico: voltagem de $100 \mathrm{kV}$; corrente de $100 \mu \mathrm{A}$; filtro de $\mathrm{Al}+\mathrm{Cu}$ e resolução de $9.92 \mu \mathrm{m}$. Para as análises morfométricas $2 \mathrm{D}$ e $3 \mathrm{D}$ foram utilizados os softwares CT-Analyzer (Bruker, Bélgica), NRecon fornecidos pelo fabricante do microtomógrafo e o Mimics (Materialise, Bélgica).
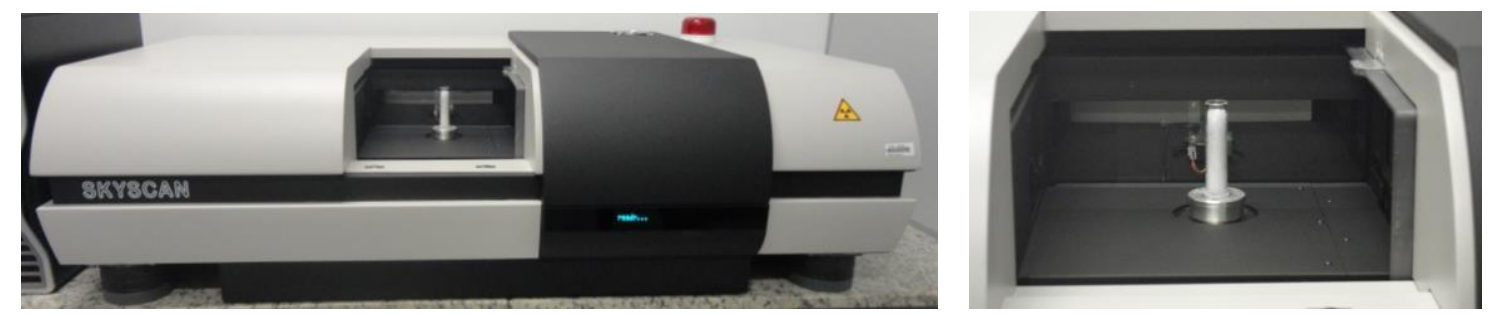

Figura 34 - Microtomógrafo com compartimento da amostra aberto antes do escaneamento das amostras ósseas.

\subsubsection{Calibração para Medida da TMD}

Os seguintes procedimentos de calibração para medida da TMD foram realizados ao se utilizar o microtomógrafo modelo 1172 e os softwares da Bruker:

1) Escaneamento simultâneo dos phantoms de hidroxiapatita de cálcio (CaHA), fornecidos pela Bruker, com densidades de 0,25 g.cm $\mathrm{cm}^{3}$ e 0,75 g.cm $\mathrm{cm}^{3}$ (Figura 35). 


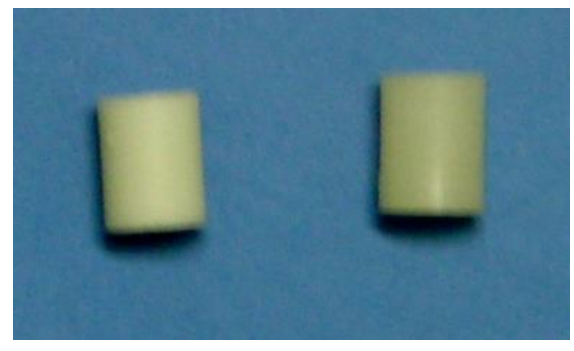

(A)

(B)

Figura 35 - Phantoms de CaHA com diâmetro de $4 \mathrm{~mm}$ e concentração de $0.25 \mathrm{~g} / \mathrm{cm}^{3}$ (A) e $0.75 \mathrm{~g} / \mathrm{cm}^{3}$ (B) (MILANETTI, 2010).

2) Reconstrução microtomográfica utilizando o software NRecon.

3) Utilização do software CT-Analyzer para a escolha de uma região de interesse (ROI) nos dois phantoms, conforme área vermelha mostrada na figura 36.

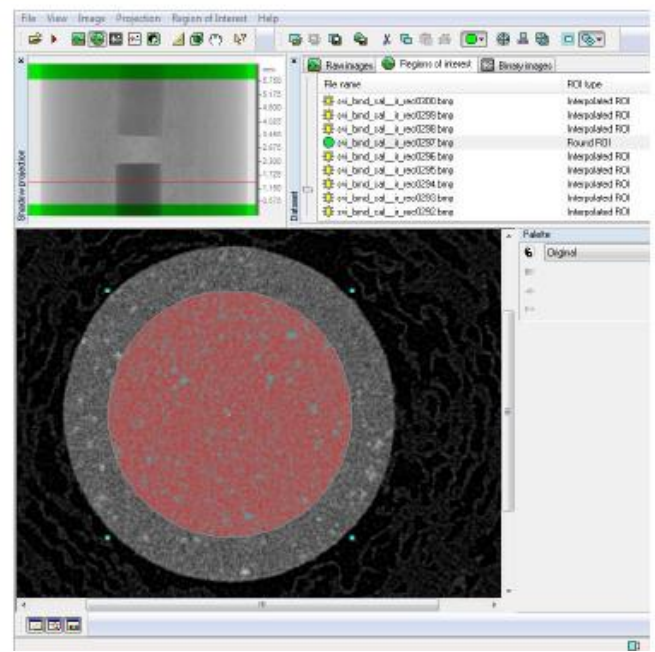

Figura 36 - ROI circular na seção transversal do phantom com concentração de $0.75 \mathrm{~g} / \mathrm{cm}^{3}$ (Bruker Method Note, 2012).

4) Escolha de 100 seções transversais em cada phantom, conforme figura 37. As seções escolhidas estão situadas na janela A da figura.

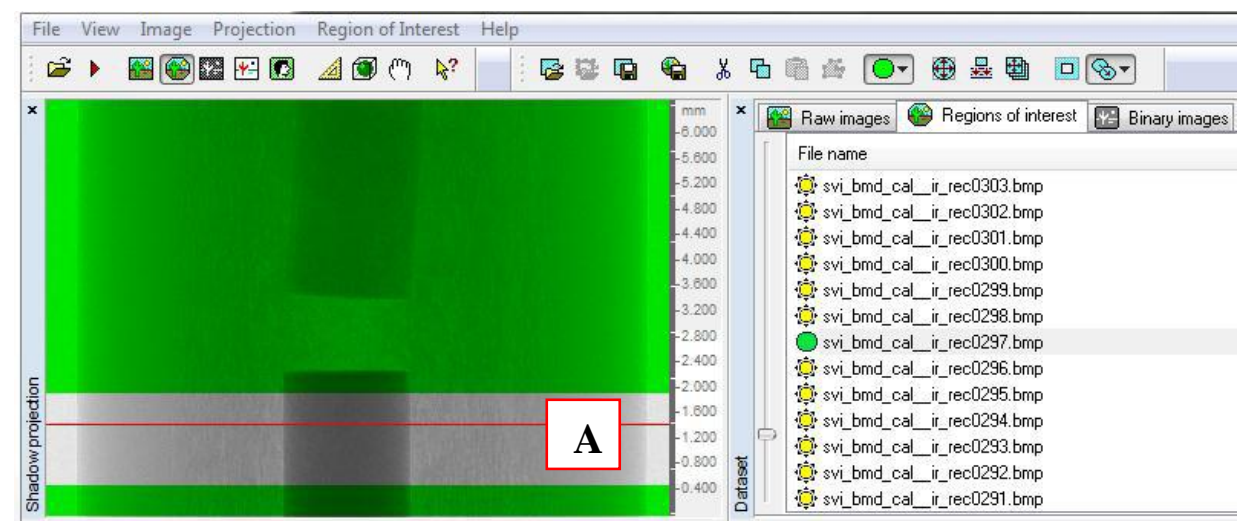

Figura 37 - Escolha das seções transversais no phantom com concentração de $0.75 \mathrm{~g} / \mathrm{cm}^{3}$ (Bruker Method Note, 2012). 
5) Medida dos coeficientes de atenuação $(\mu)$ nos volumes de interesse (VOI) dos dois phantoms que compreendem as 100 seções escolhidas. Acessar o plug-in de ROI do CTAnalyzer para carregar a VOI de um dos phantoms. Acessar o plug-in binário do CT-Analyzer para observar o histograma de densidade. A figura 38 mostra qual ícone deve ser clicado (retângulos vermelhos) para se observar o histograma de uma das seções, de todo o phantom e da VOI selecionada.

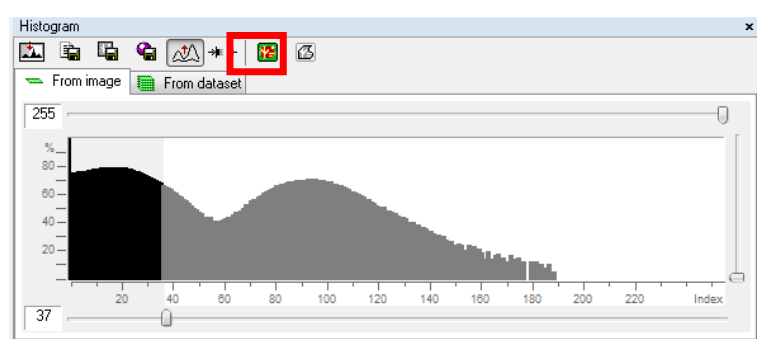

(A)

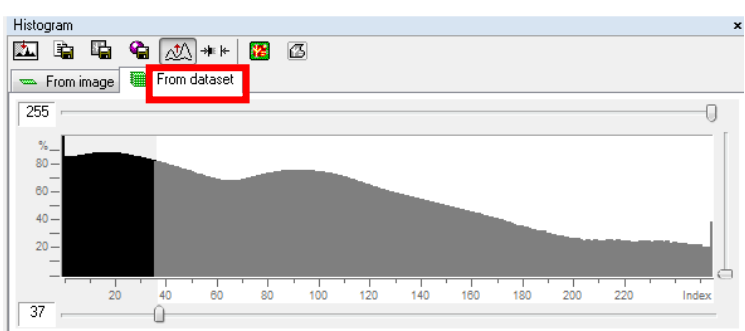

(B)

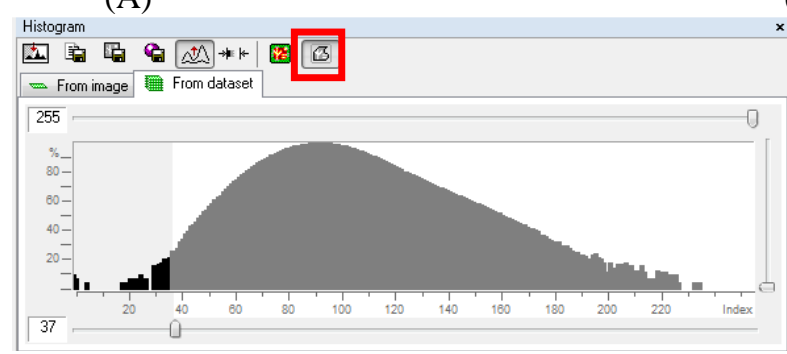

(C)

Figura 38 - Histogramas de densidade de uma seção da VOI (A), de todas as seções da amostra (B) e da VOI (C) (Bruker Method Note, 2012).

6) Determinação do coeficiente de atenuação médio na VOI selecionada de cada phantom através do plug-in de histograma. Os valores médios dos coeficientes de atenuação foram 0.02532 e 0.05885 para os phantoms com $0.25 \mathrm{~g} / \mathrm{cm}^{3}$ e $0.75 \mathrm{~g} / \mathrm{cm}^{3}$, respectivamente.

7) Determinação da equação que determina a BMD com base nos coeficientes de atenuação. No plug-in de histograma seleciona-se a função "Calibrate" e digitam-se os valores da BMD e do coeficiente médio de atenuação de cada phantom, conforme figura 39. A equação de regressão linear é fornecida:

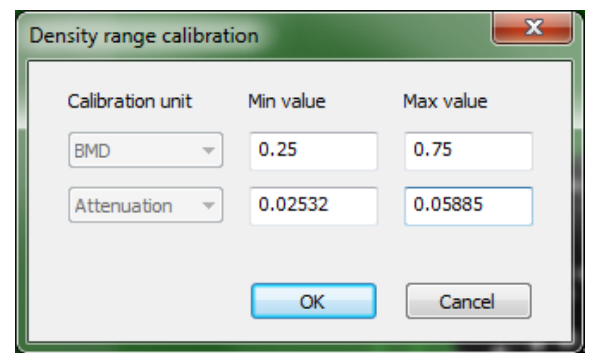

$$
B M D=\frac{A C-0.008555}{0.06706}
$$

Figura 39: Determinação da equação da BMD em função dos valores médios dos coeficientes de atenuação (Bruker Method Note, 2012). 


\subsubsection{Medida da TMD em Osso Trabecular}

Os seguintes procedimentos para medida da BMD foram utilizados ao se utilizar o microtomógrafo modelo 1172 e softwares da Bruker:

1) Carregar os arquivos de reconstrução de uma amostra óssea.

2) Seleção de uma VOI de interesse nas seções transversais da amostra óssea. Na figura 40 a VOI está situada nas seções transversais entre as regiões verdes da janela A. A ROI de interesse em uma seção é mostrada com a cor vermelha na janela B.

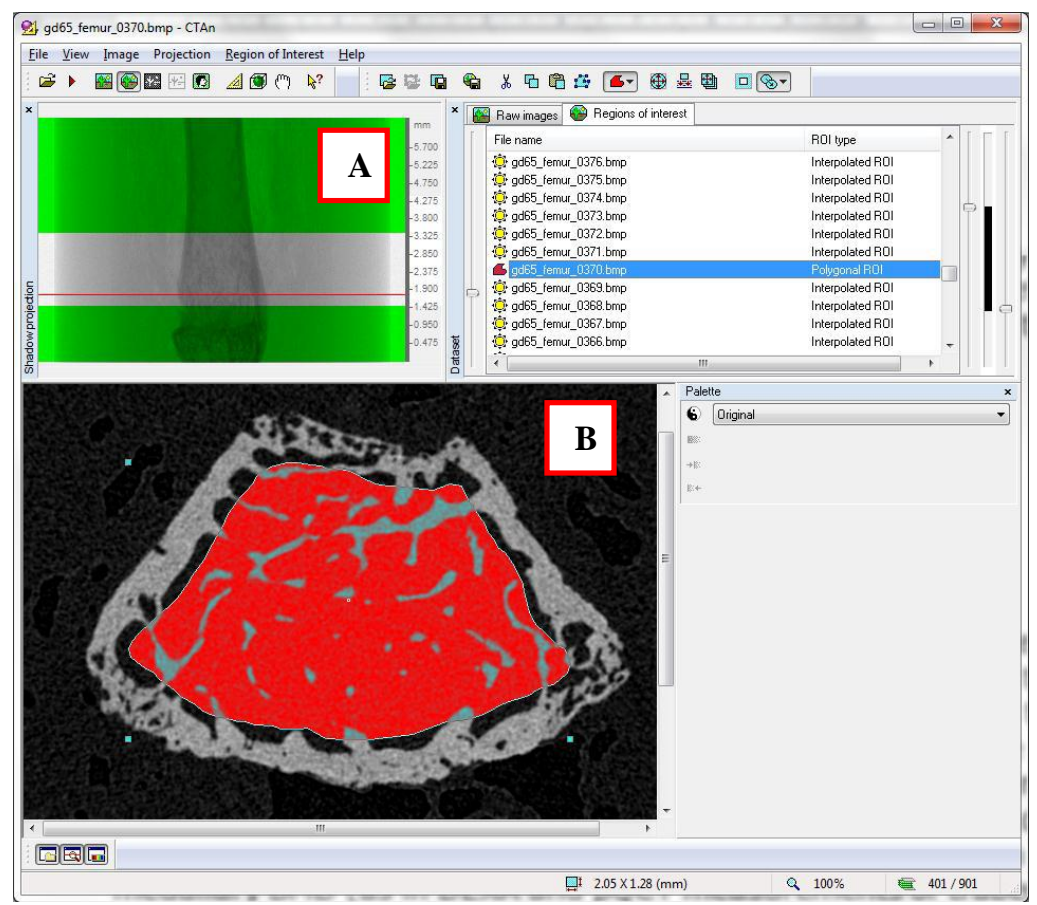

Figura 40 - Seleção da ROI para medida da TMD no osso trabecular (Bruker Method Note, 2012).

3) Selecionar as ROIs de interesse na VOI escolhida, conforme figura 41. 


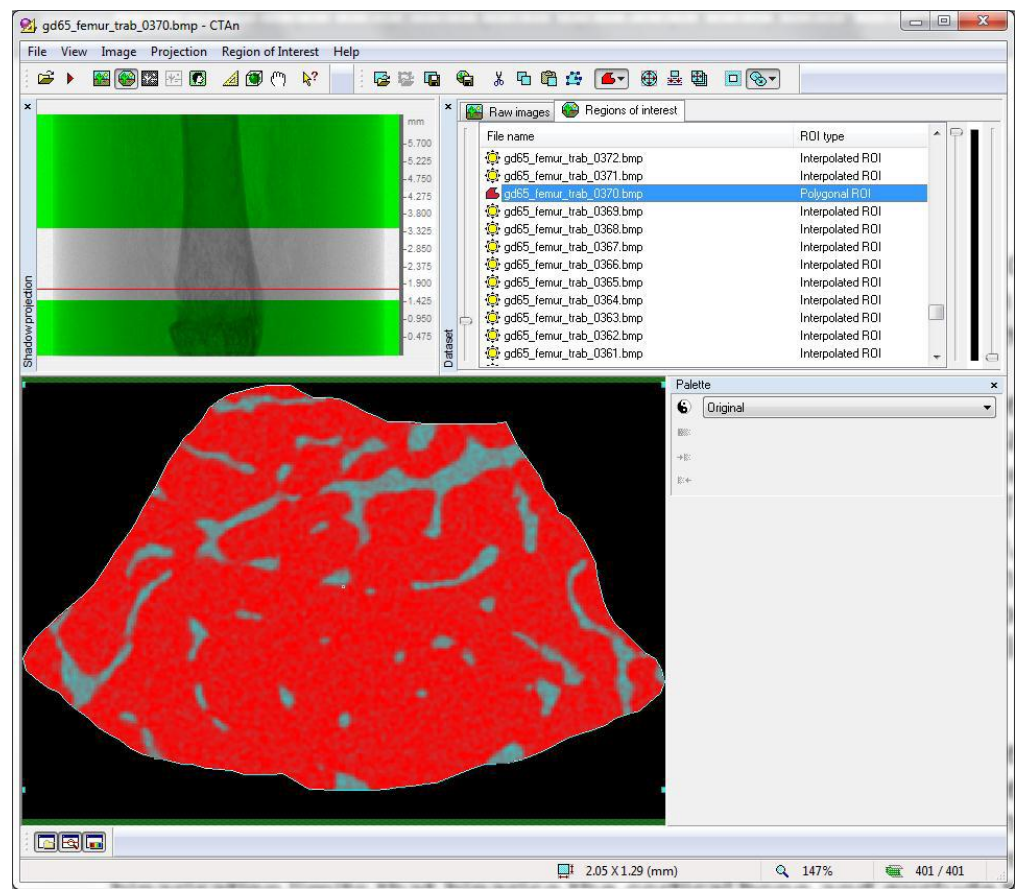

Figura 41 - ROI contendo osso trabecular na VOI de interesse (Bruker Method Note, 2012).

4) Binarização das seções transversais da VOI para segmentação das imagens para que o osso trabecular seja separado do osso trabecular, conforme ilustrado na figura 42.
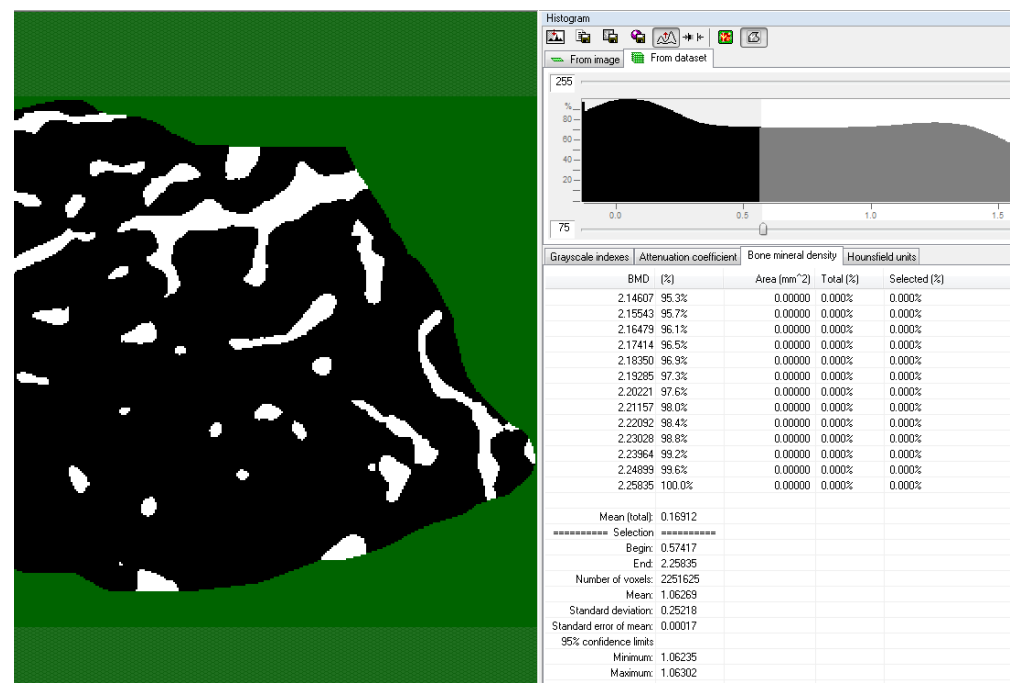

Figura 42 - Binarização para segmentação do osso trabecular (Bruker Method Note, 2012).

Cálculo da TMD média do osso trabecular existente na VOI através do plug-in que utiliza a equação que relaciona a TMD como função dos coeficientes de atenuação $(\mu)$. 


\subsubsection{Medida da BMD em Osso Cortical}

1) Carregar os arquivos de reconstrução de uma amostra óssea.

2) Seleção de uma ROI de interesse nas seções transversais da amostra óssea. Na figura 43 a VOI está situada nas seções transversais entre as regiões verdes. A ROI de interesse em cada seção é mostrada com a cor amarela.

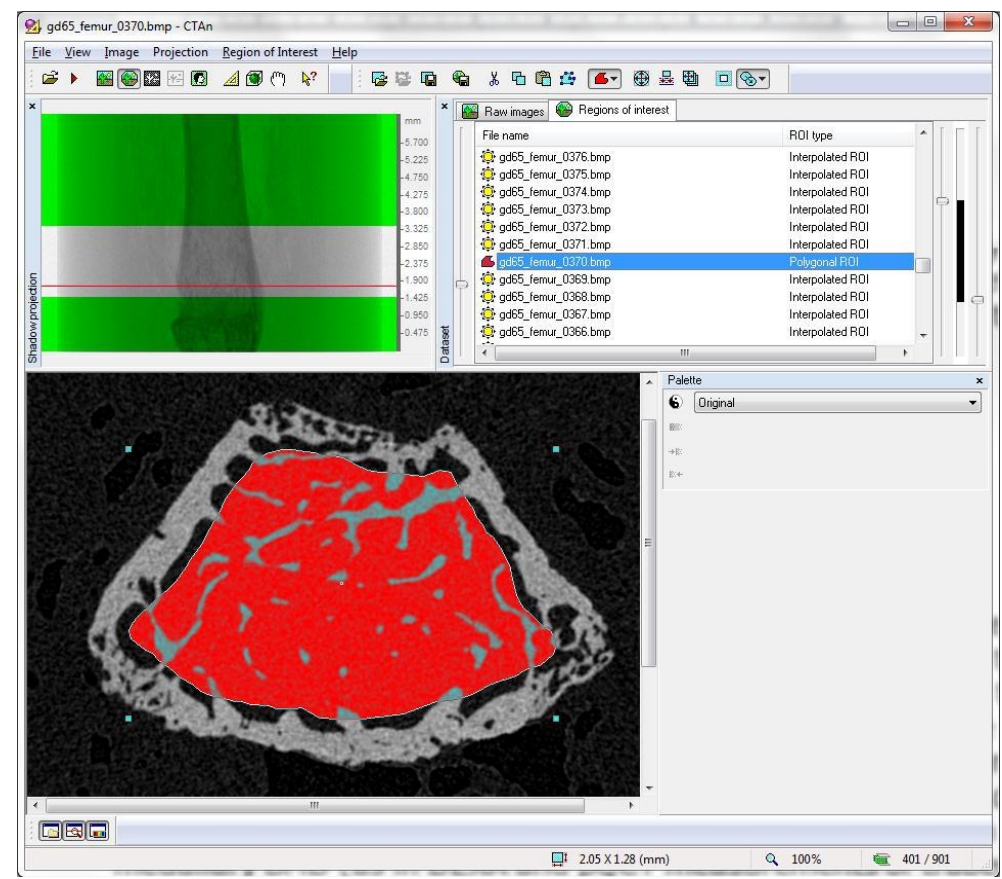

(A)

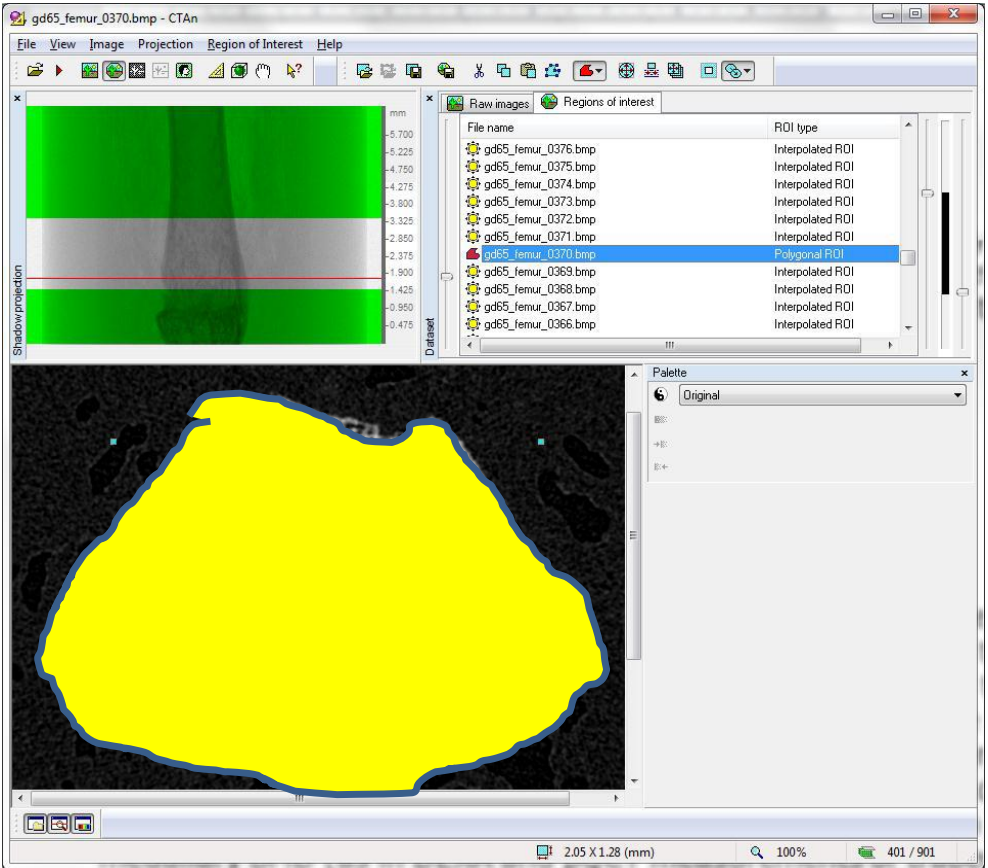

(B)

Figura 43 - Seleção da ROI para medida da TMD no osso cortical: seleção da ROI contendo osso trabecular e cortical (B) (Bruker Method Note, 2012). 
3) Binarizar as ROIs de interesse e segmentar para separar o osso cortical do osso trabecular, conforme figura 44.

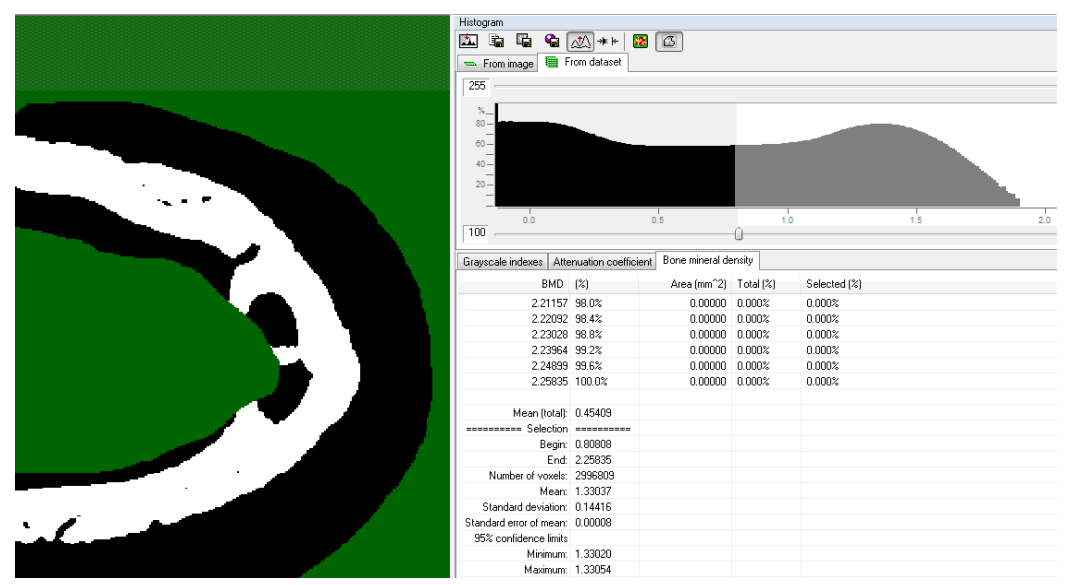

Figura 44 - Binarização para segmentação do osso cortical (Bruker Method Note, 2012).

4) Cálculo da TMD média do osso cortical existente na VOI através do plug-in que utiliza a equação que relaciona a BMD como função dos coeficentes de atenuação $(\mu)$.

\subsubsection{Análise Microtomográfica por Raio-X}

Os seguintes procedimentos da análise microtomográfica por raio-x foram realizados através do software CT-Analyzer, versão 1.13.10 (Bruker, Bélgica):

Etapa 1: Abrir os arquivos de reconstrução microtomográfica de uma amostra óssea, conforme esquematizado na figura 45. Na janela B da imagem estão listados os arquivos imagem das seções transversais da amostra que aparecem na janela $\mathrm{C}$. 


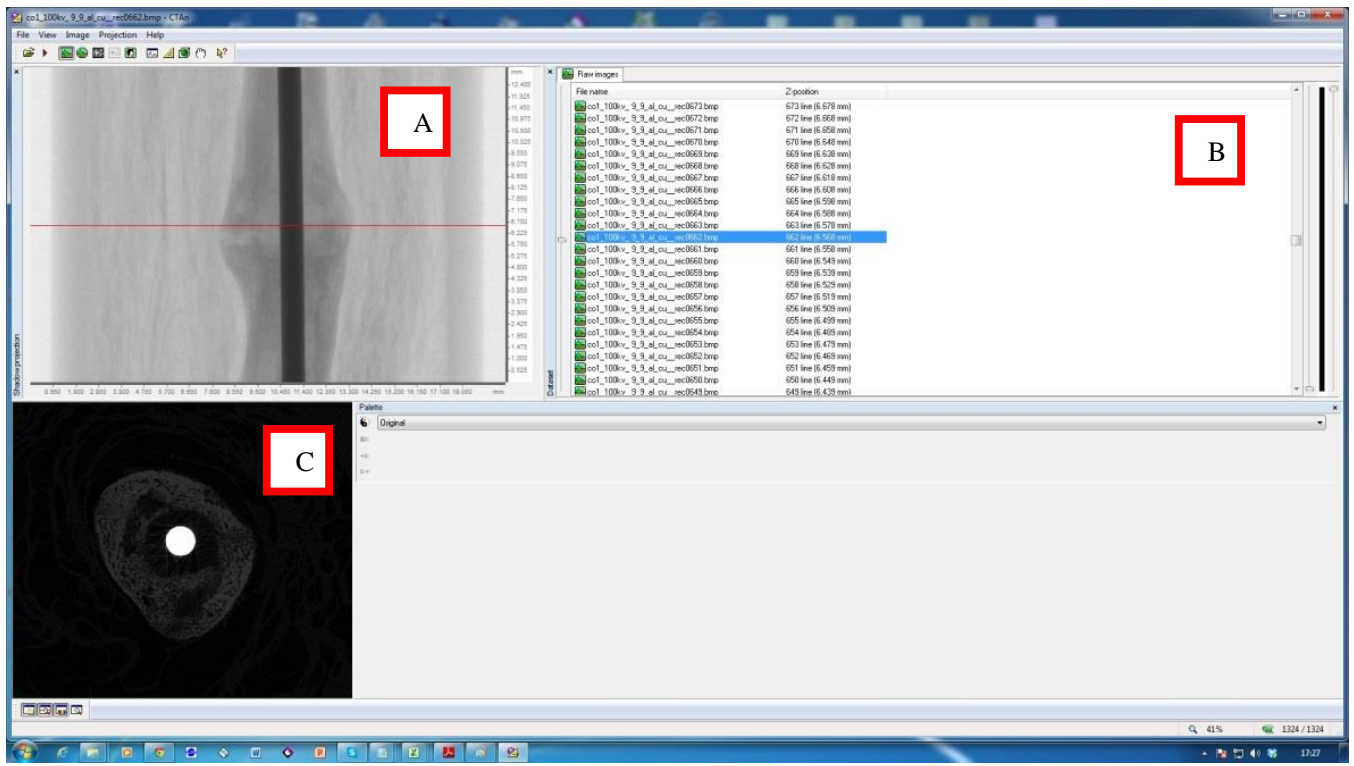

Figura 45 - Procedimento de abrir os arquivos de reconstrução microtomográfica de uma amostra.

Etapa 2: Selecionar a seção transversal superior da VOI. Na Figura 46, janela A, a linha vermelha delimita a seção transversal superior da VOI, cuja imagem aparece na janela C.

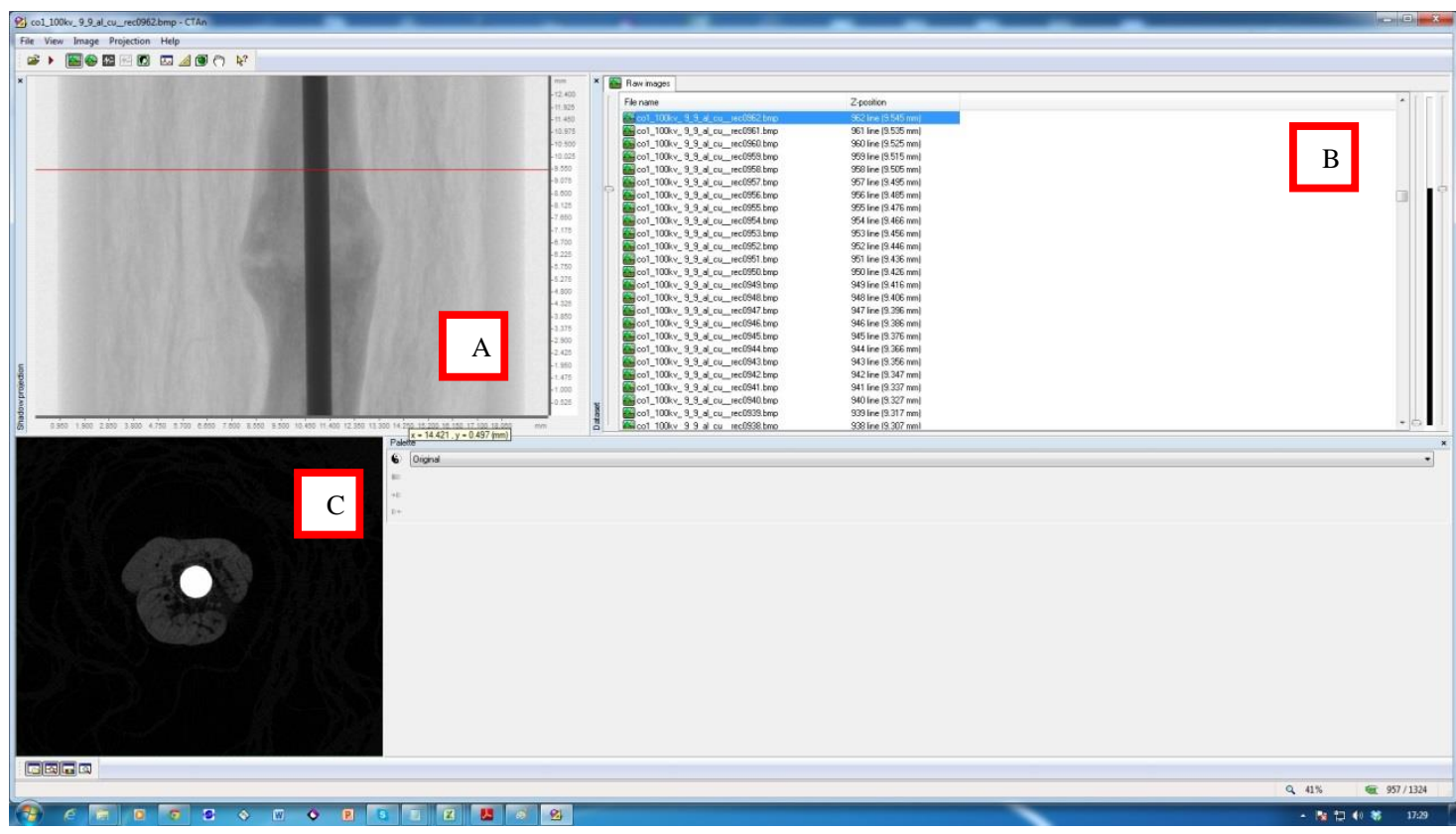

Figura 46 - Procedimento de escolha da seção transversal superior da VOI.

Etapa 3: Selecionar a seção transversal inferior da VOI. Na Figura 47, janela A, a linha vermelha delimita a seção transversal inferior da VOI, cuja imagem aparece na janela C. 


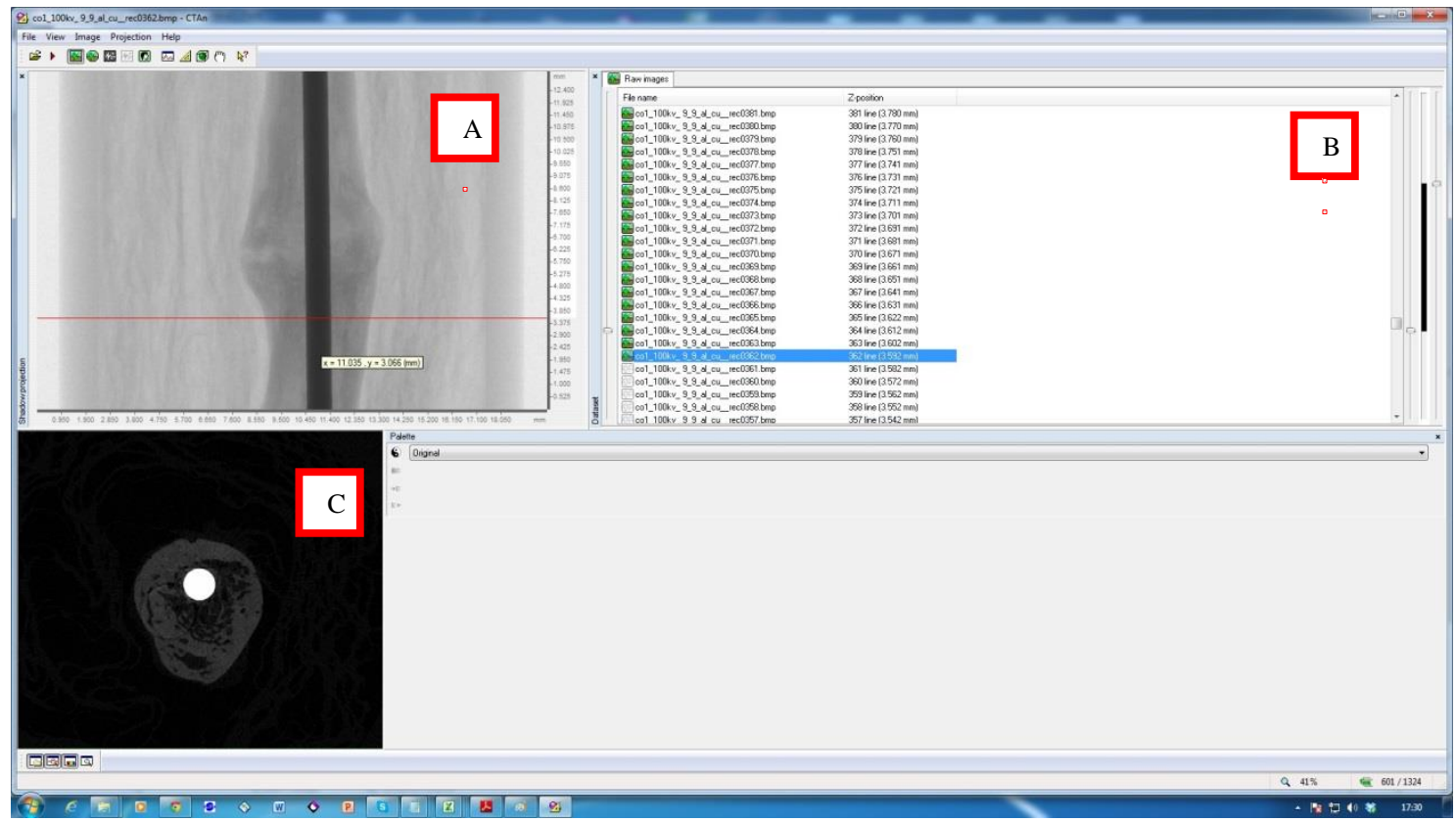

Figura 47 - Procedimento de escolha da seção transversal inferior da VOI.

Etapa 4: Definir a VOI a partir da seção transversal superior e inferior. Na Figura 48 a janela A mostra a VOI escolhida. Na janela B a linha vermelha marca a seção transversal mostrada em na janela D.

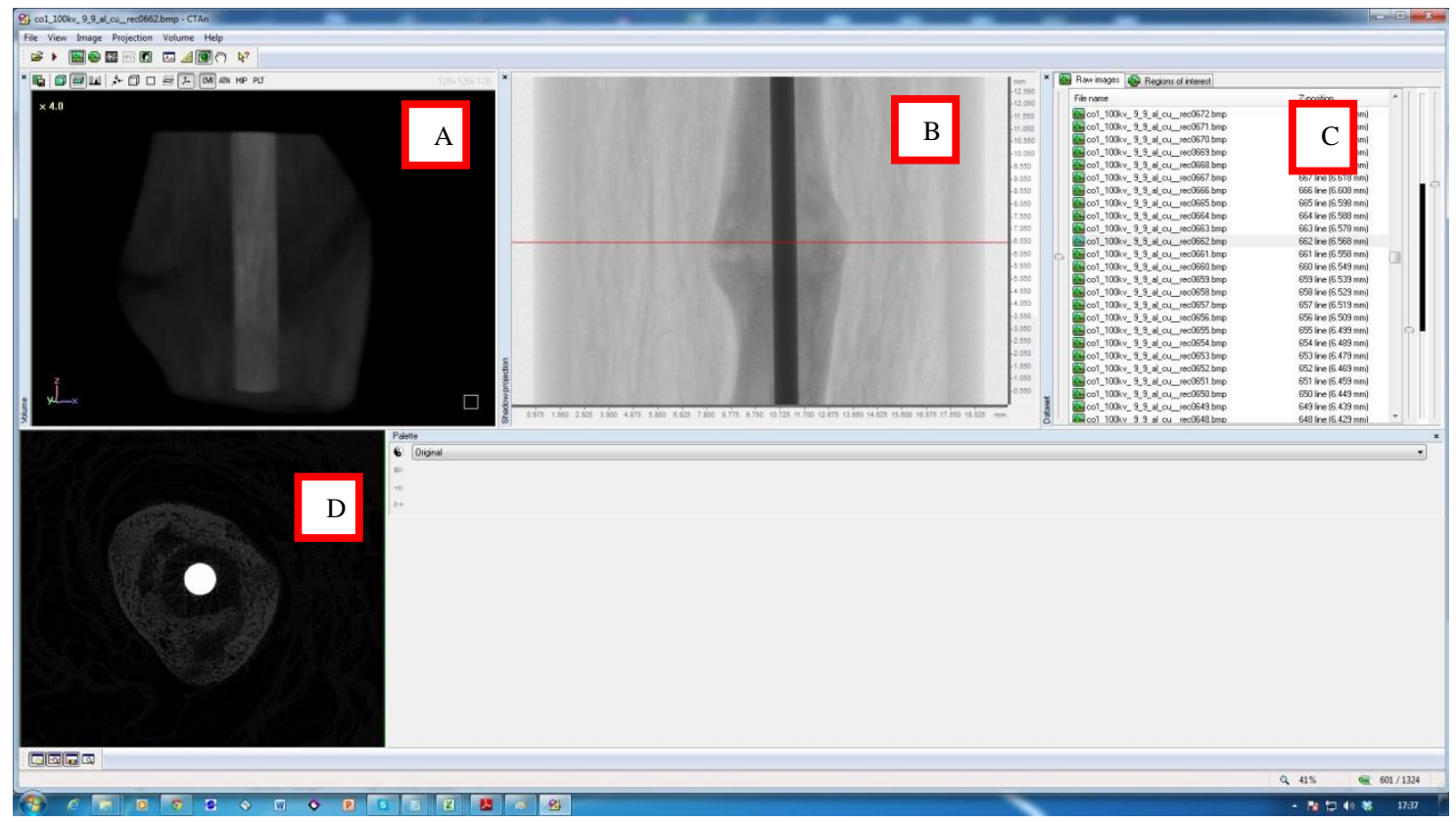

Figura 48 - Definição da VOI da amostra.

Etapa 5: Escolher a ROI da VOI da amostra. A ROI vermelha mostrada na janela D deve conter a seção transversal escolhida na janela B. A linha vermelha deve percorrer a VOI 
(acima e abaixo) para se observar se a ROI escolhida contem qualquer seção transversal (Figura 49).

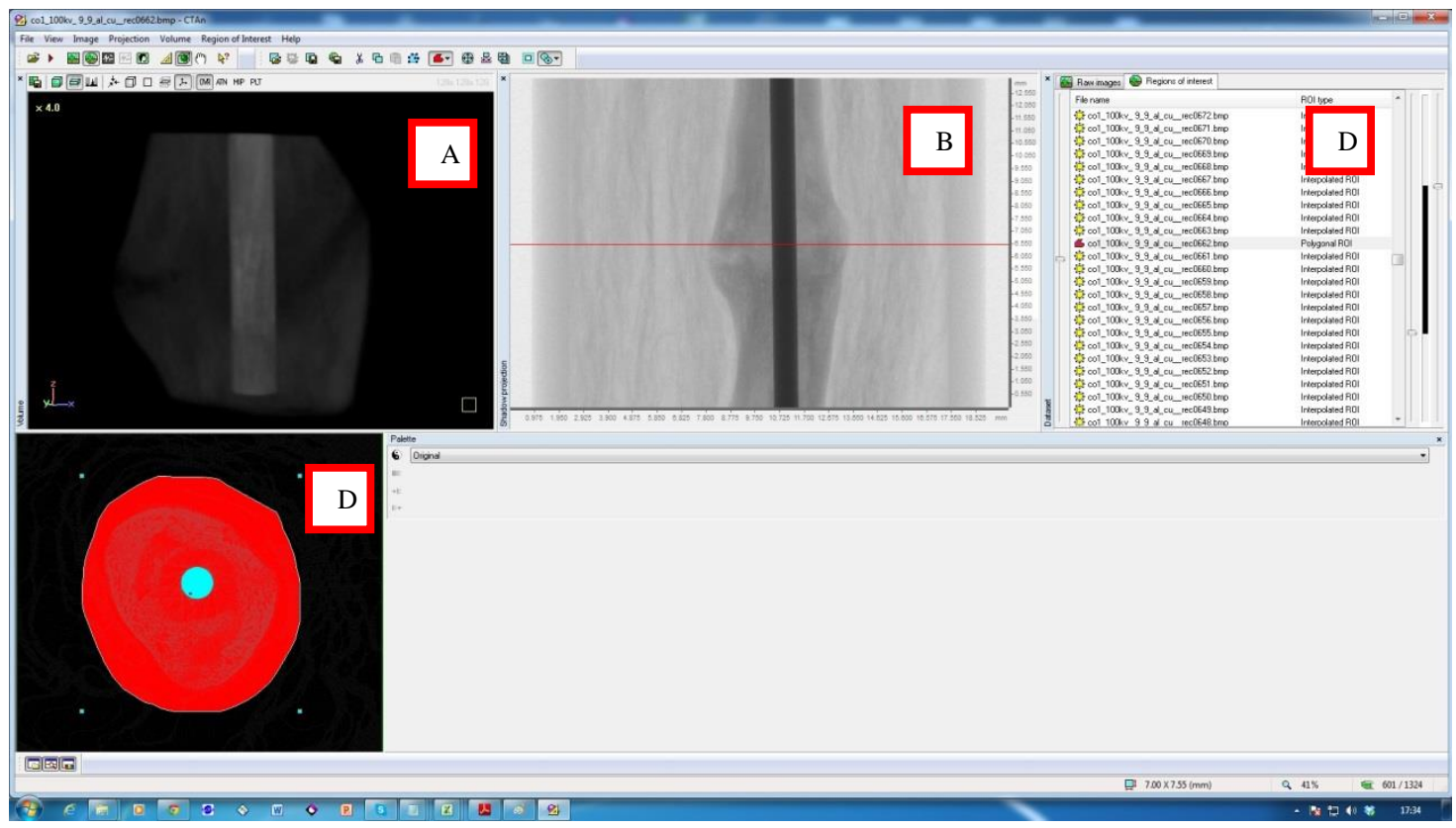

Figura 49 - Escolha da ROI da VOI da amostra.

Etapa 6: Carregar a task list com plug-ins de processamentos de imagem e de algoritimos topológicos que serão aplicados nas seções transversais da amostra. A task list é mostrada na janela E (Figura 50).

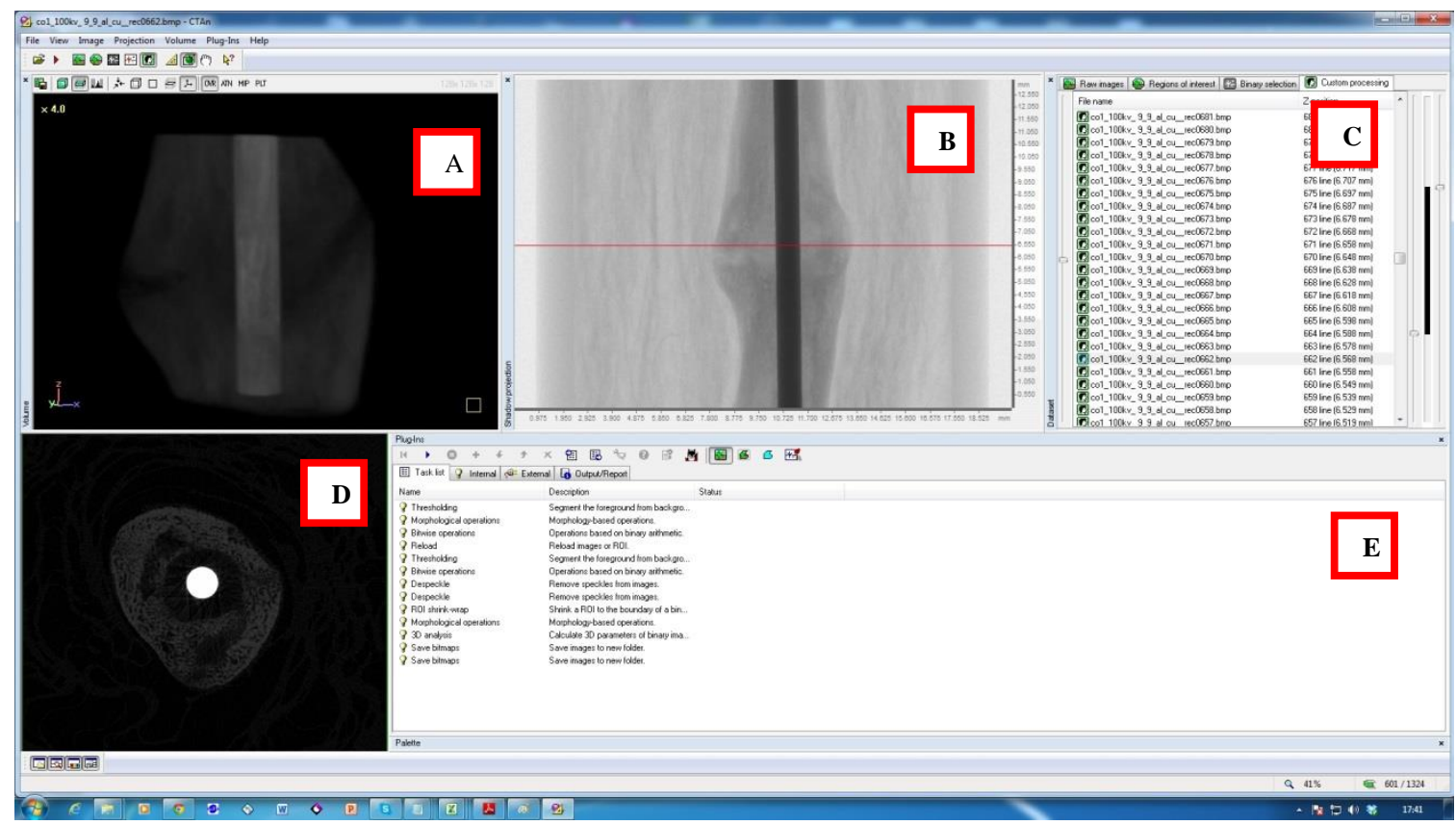

Figura 50 - Carregamento da task list. 
Etapa 7: Aplicar thresholding para seleção da fio de Kirchner utilizado na cirurgia porque a VOI utilizada na análise microtomográfica não deve conter o fio de Kirschner. Um thresholding com pixels entre 200 e 255 mostrados na janela $E$ foi utilizado para isolar o fio de Kirschner, conforme janela D (Figura 51).

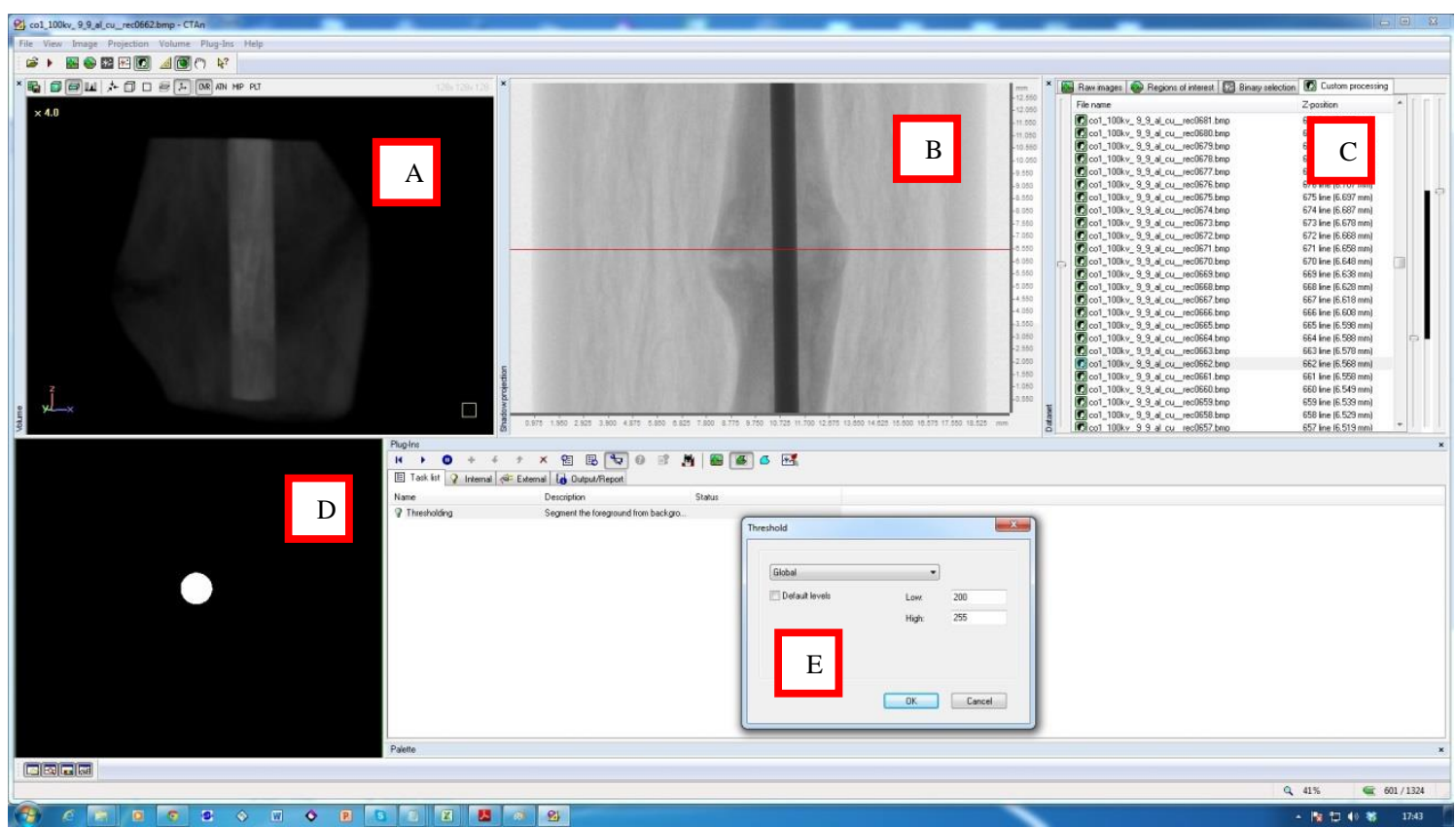

Figura 51 - Aplicação de thresholding para seleção do fio de Kirschner.

Etapa 8: Dilatar as imagens obtidas na etapa 7. A dilatação observada na Janela D através do plug-in "dilation" selecionado na janela E é utilizado para garantir a extração do fio de Kirschner (Figura 52).

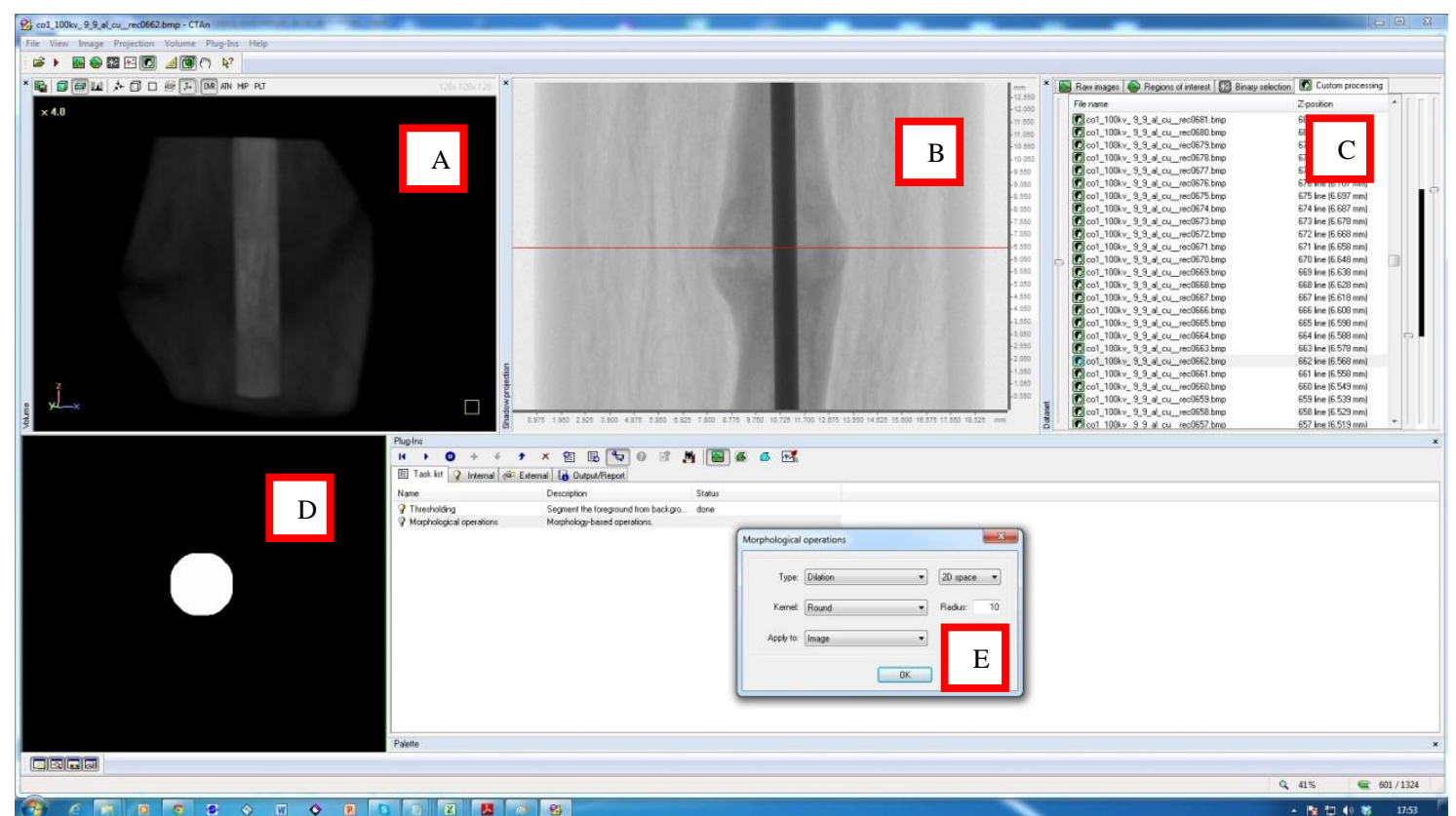

Figura 52 - Procedimento de dilatação das imagens do fio de Kirschner. 
Etapa 9: Remover as imagens dilatadas obtidas na etapa 8. Um plug-in "not image" de processamento de imagem foi utilizado para eliminar o fio de Kirschner, conforme janela E (Figura 53).

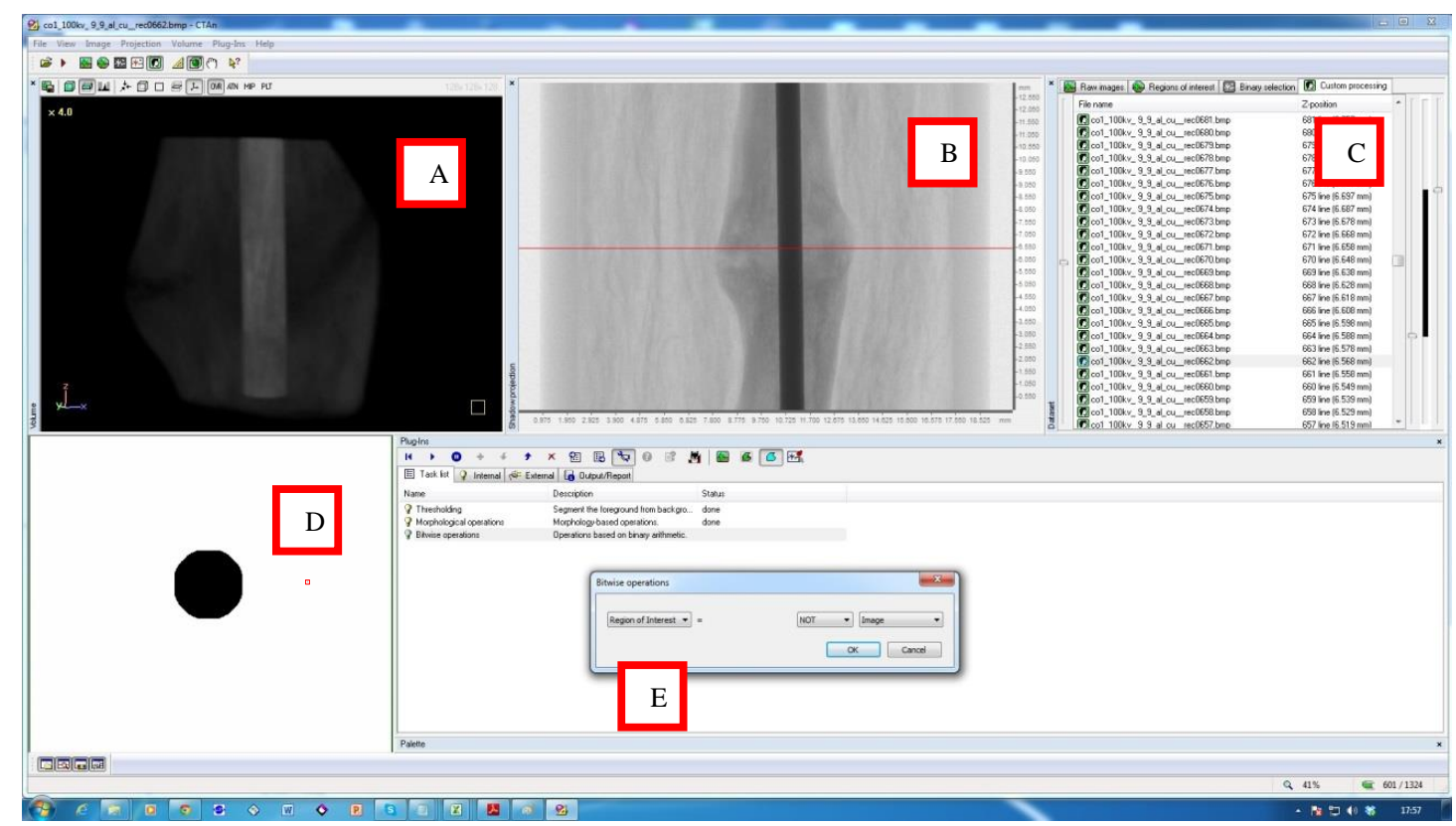

Figura 53 - Remoção das imagens dilatadas do fio de Kirschner.

Etapa 10: Carregar as imagens das seções transversais para visualização da eliminação do fio de Kirschner após utilização do plug-in "apply to image" de processamento de imagem. Na janela D não aparece o fio de Kirschner na seção transversal selecionada em B (Figura 54).

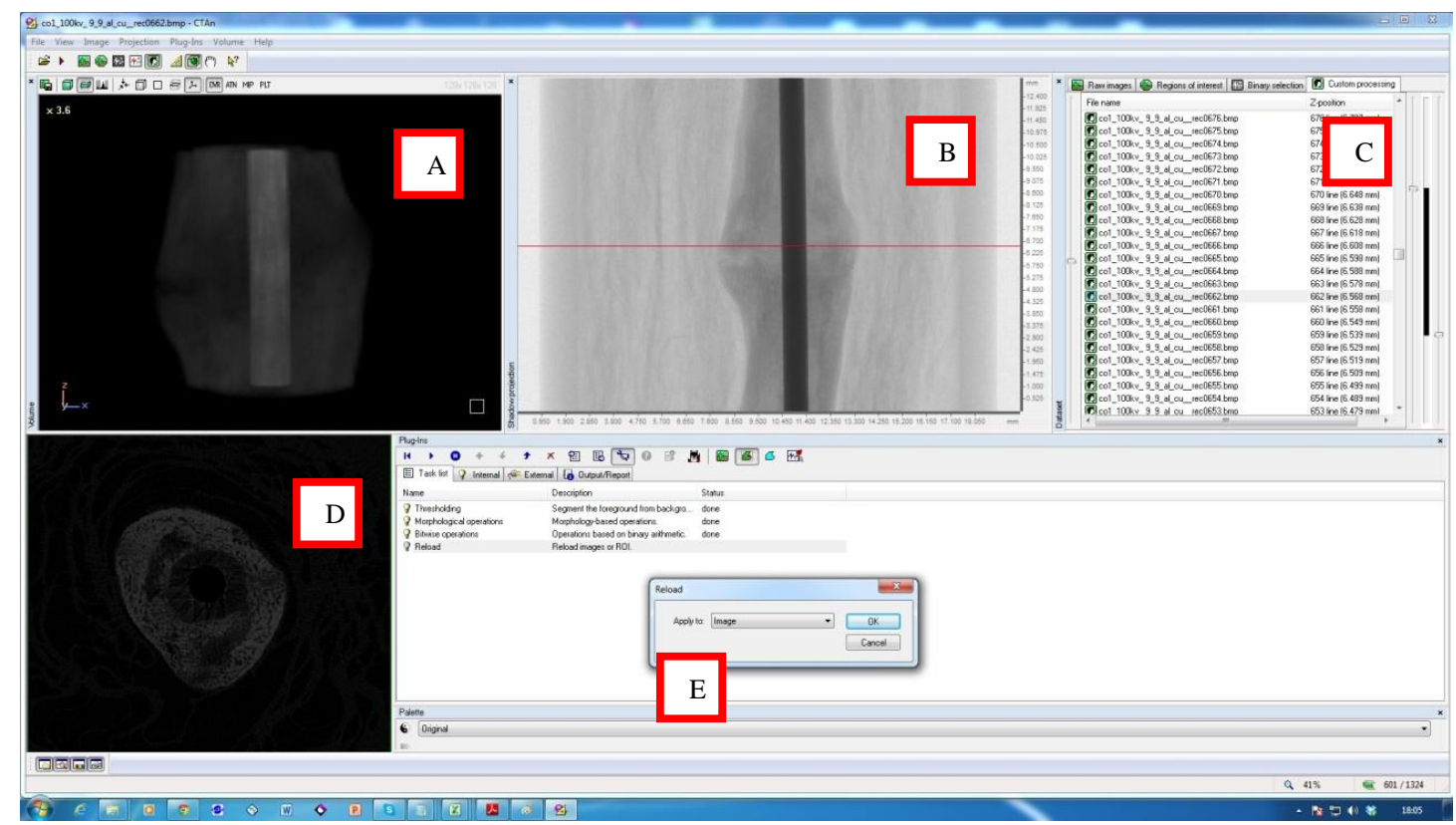

Figura 54 - Visualização da eliminação do fio de Kirschner em uma das seções transversais da amostra. 
Etapa 11: Thresholding das seções transversais sem a presença do fio de Kirschner. O intervalo de 32 a 255 foi utilizado para digitalização dos níveis de cinza, conforme janela E. Uma seção digitalizada é mostrada na janela D (Figura 55).

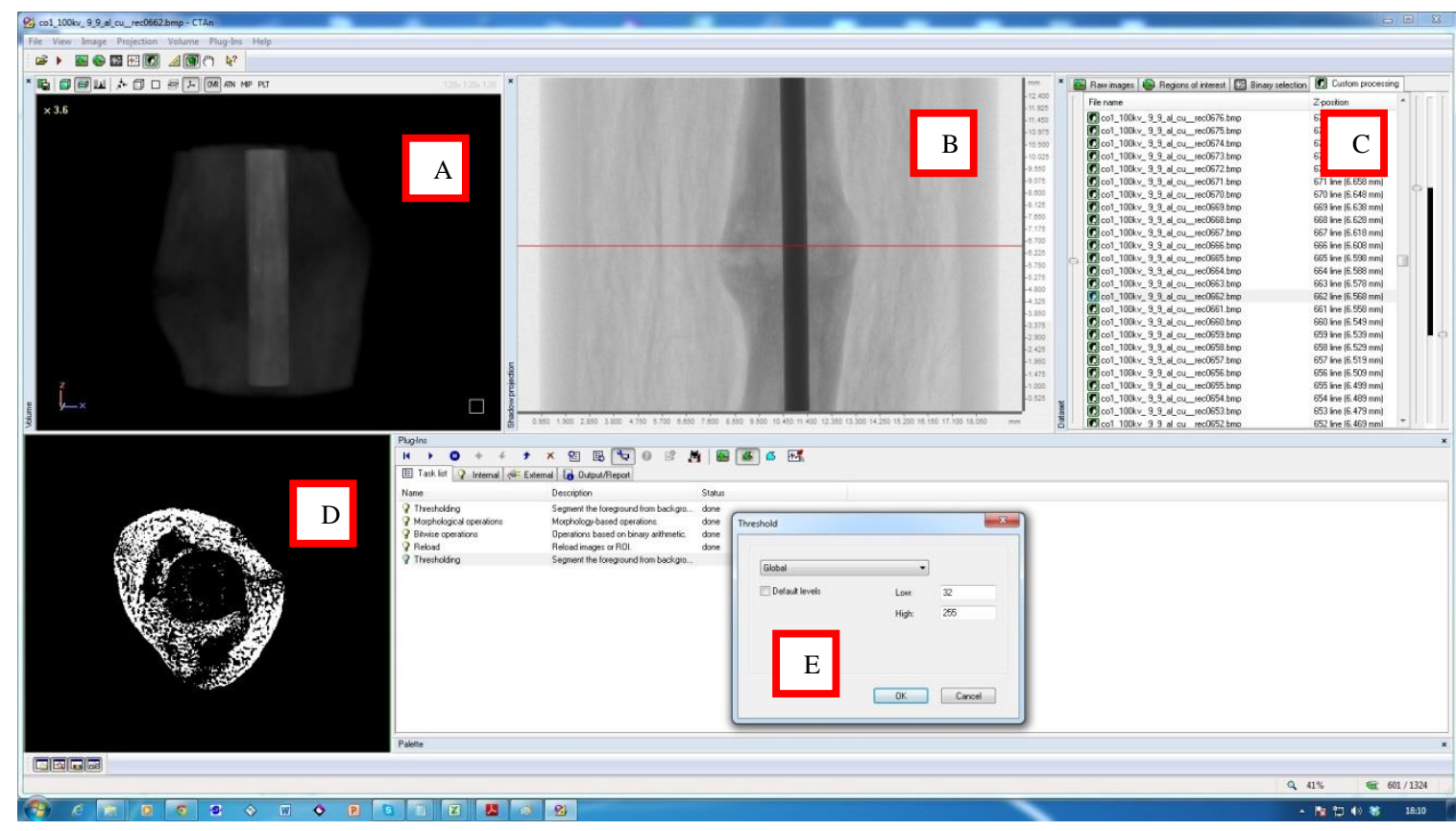

Figura 55 - Thresholding das seções transversais sem a presença do fio de Kirschner.

Etapa 12: Definir a uma nova VOI contendo as seções digitalizadas da etapa 11 (Figura 56).

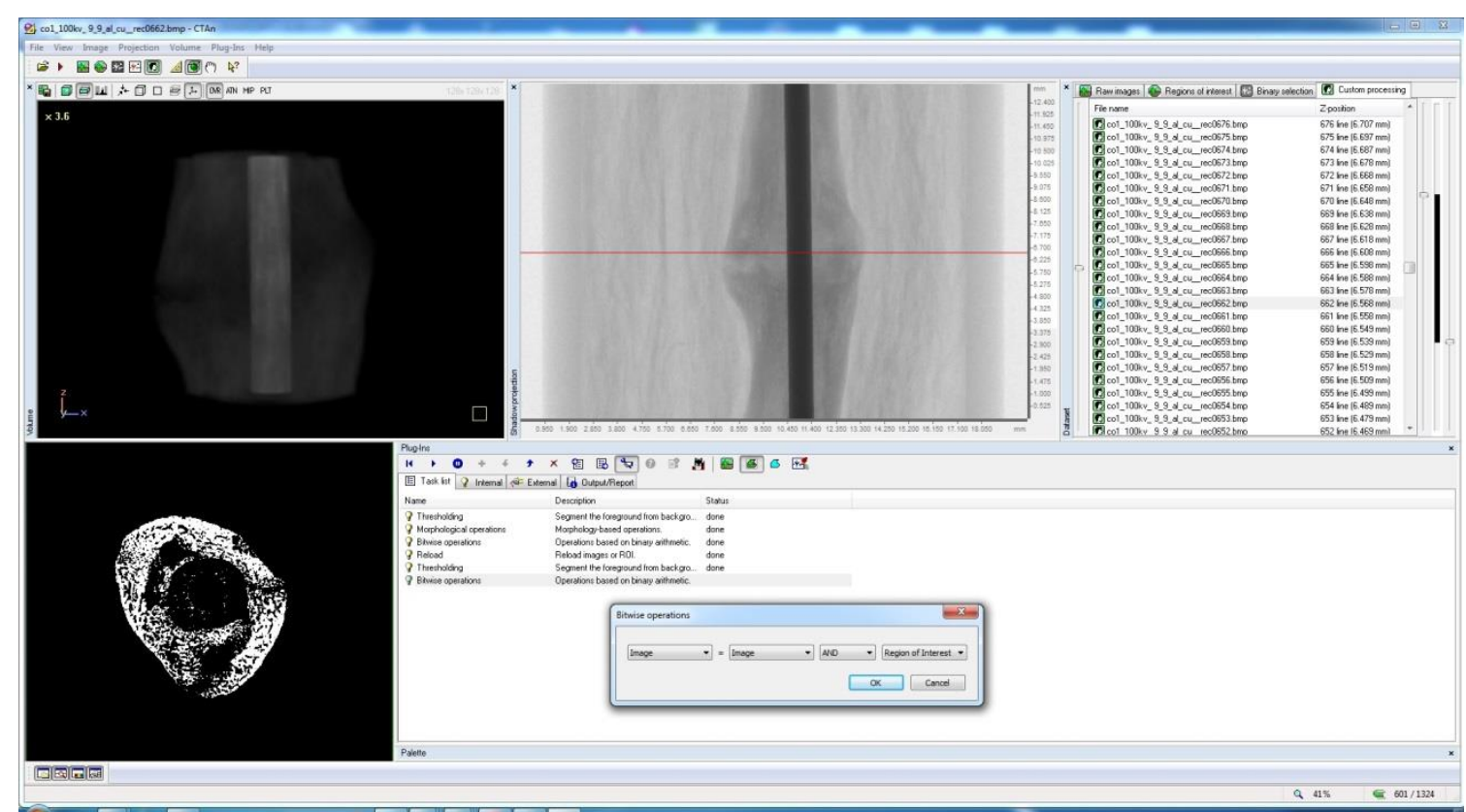

Figura 56 - Definição da VOI contendo as seções digitalizadas.

Etapa 13: Remover os pixels não pertencentes às seções transversais e localizados na periferia das mesmas com o plug-in "despeckle" de processamento de sinal selecionado na janela E. 
Ao se percorrer as seções da amostra através da janela B é possível observar na janela D que são retirados os pixels não pertencentes às seções (Figura 57).

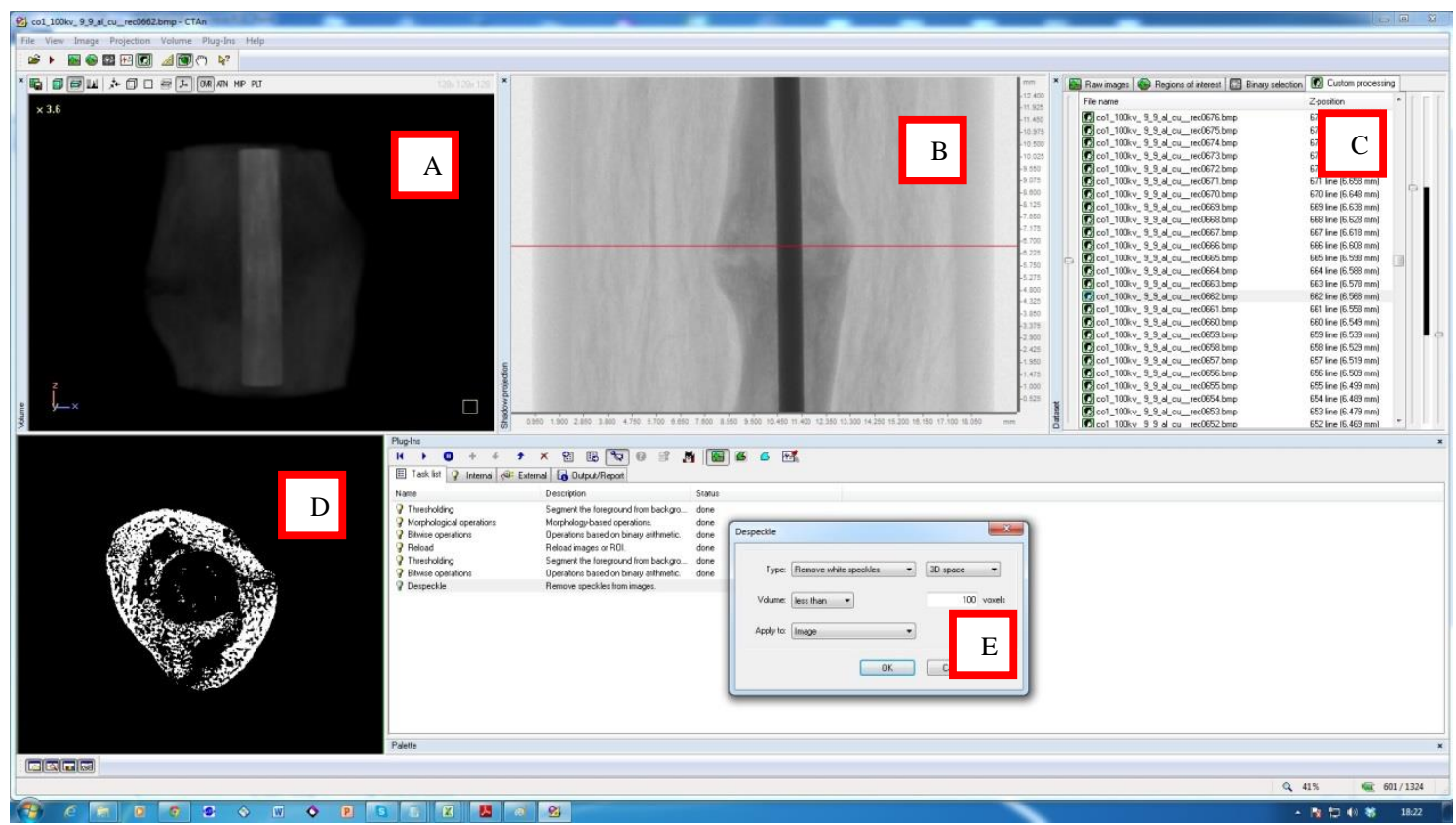

Figura 57 - Remoção de pixels não pertencentes às seções transversais e localizados na periferia das mesmas.

Etapa 14: Remover os poros não pertencentes às seções transversais com o plug-in “despeckle” de processamento de sinal selecionado na janela E. Ao se percorrer as seções da amostra através da janela B é possível observar na janela D que são retirados os poros não pertencentes às seções (Figura 58).

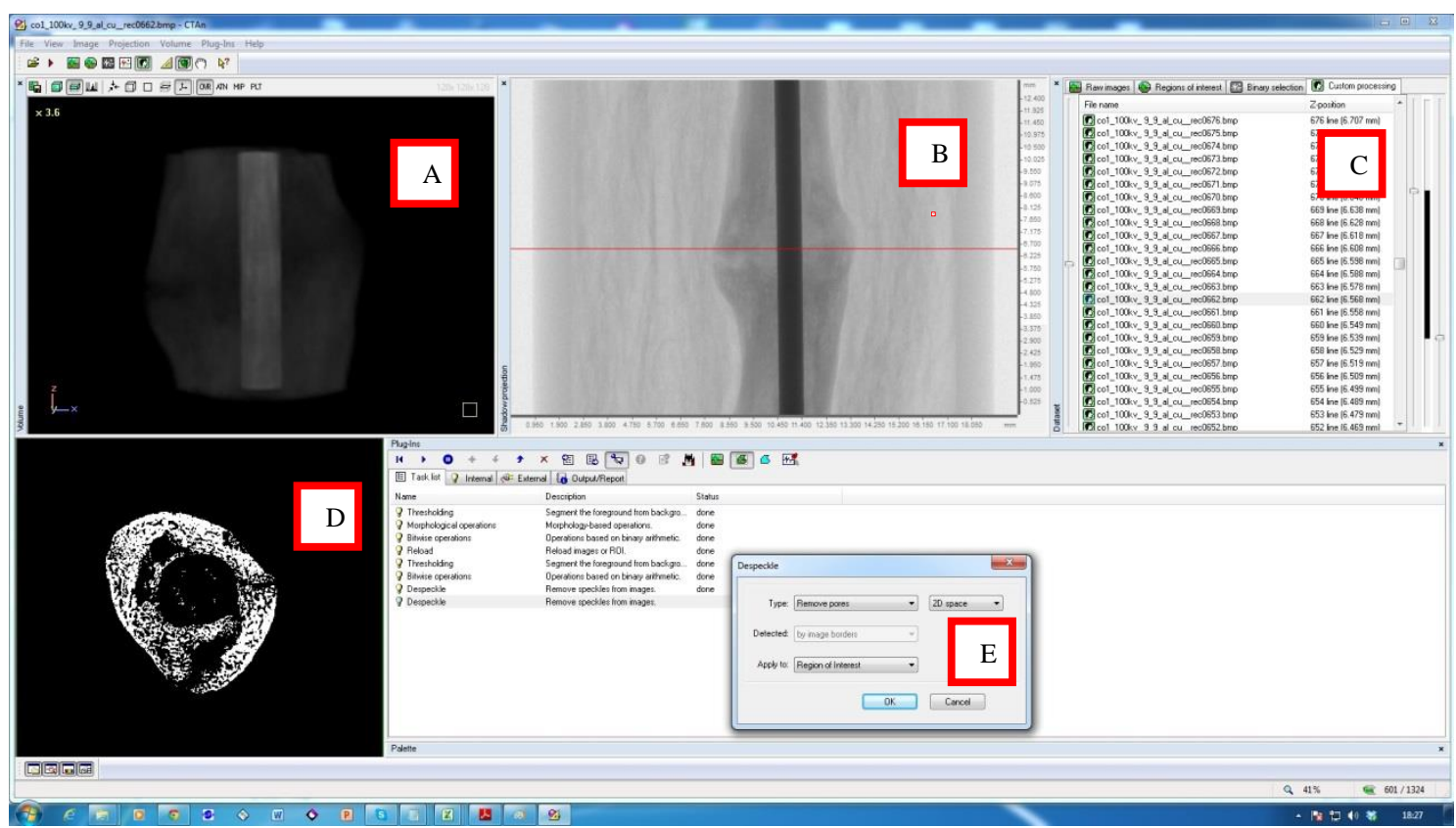

Figura 58 - Remoção dos poros não pertencentes às seções transversais. 
Etapa 15: Selecionar o contorno das seções transversais digitalizadas com o plug-in "shrinkwrap" de processamento de imagem. O contorno define a ROI de cada seção onde parâmetros morfométricos e topológicos serão calculados, conforme mostrado em D (Figura 59).

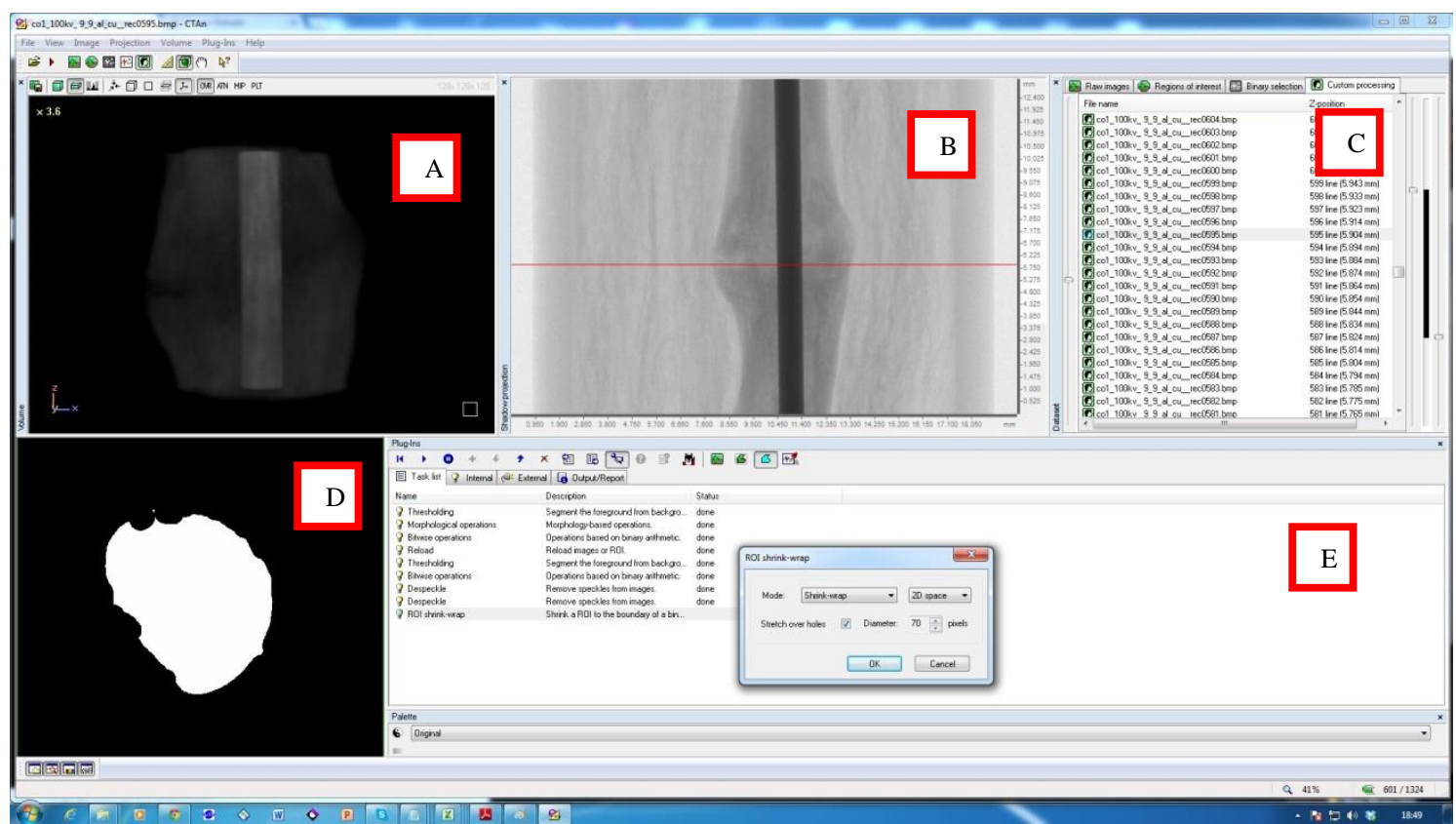

Figura 59 - Seleção do contorno das seções transversais.

Etapa 16: Refinar o contorno da ROI de cada seção transversal através do plug-in "opening” de processamento de imagem que é observado na janela D (Figura 60).

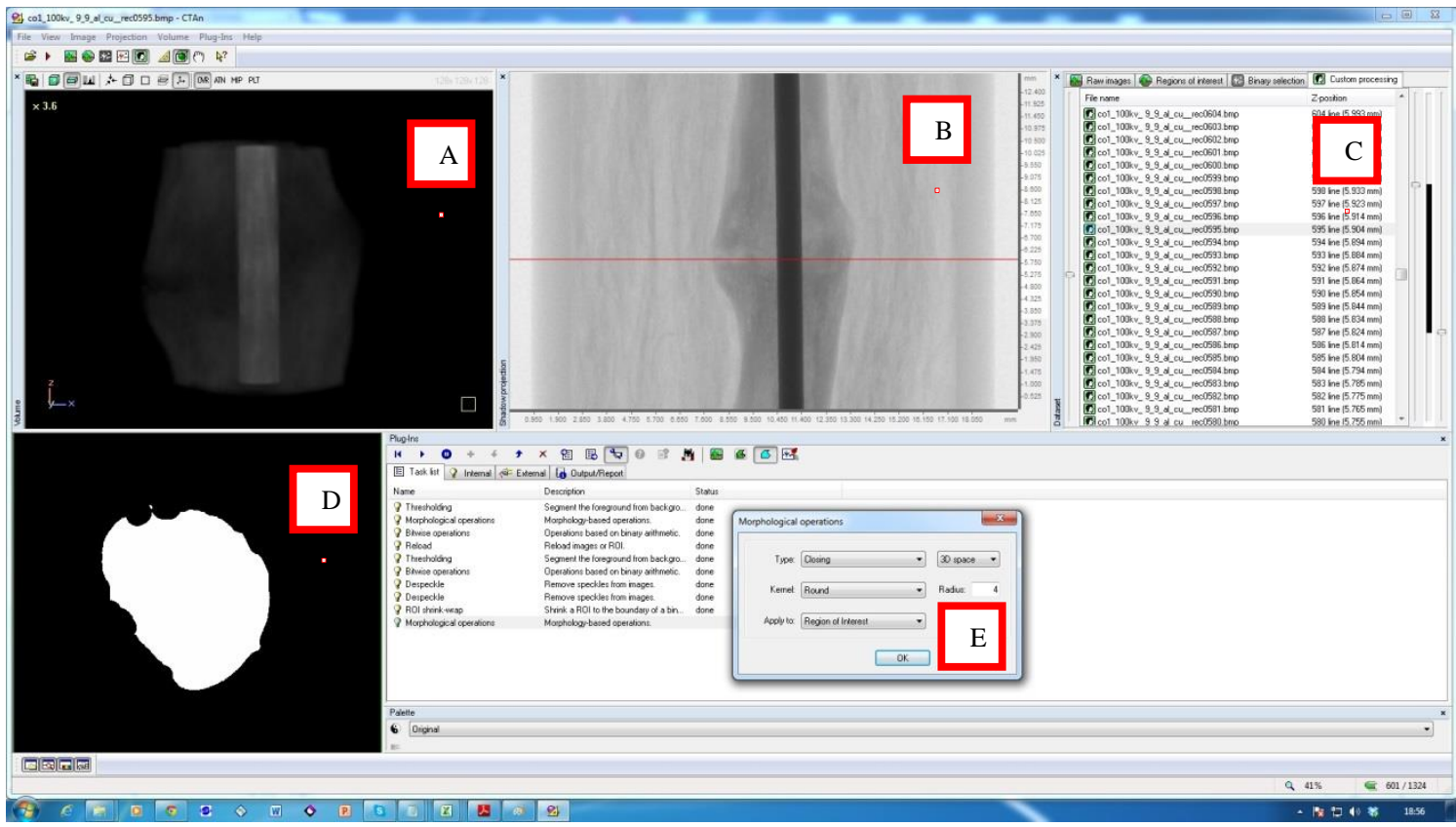

Figura 60 - Refinamento do contorno da ROI de cada seção transversal.

Etapa 17: Escolher os parâmetros morfométricos a serem calculados através do plug-in " $3 D$ Analysis" mostrado na janela E (Figura 61). 


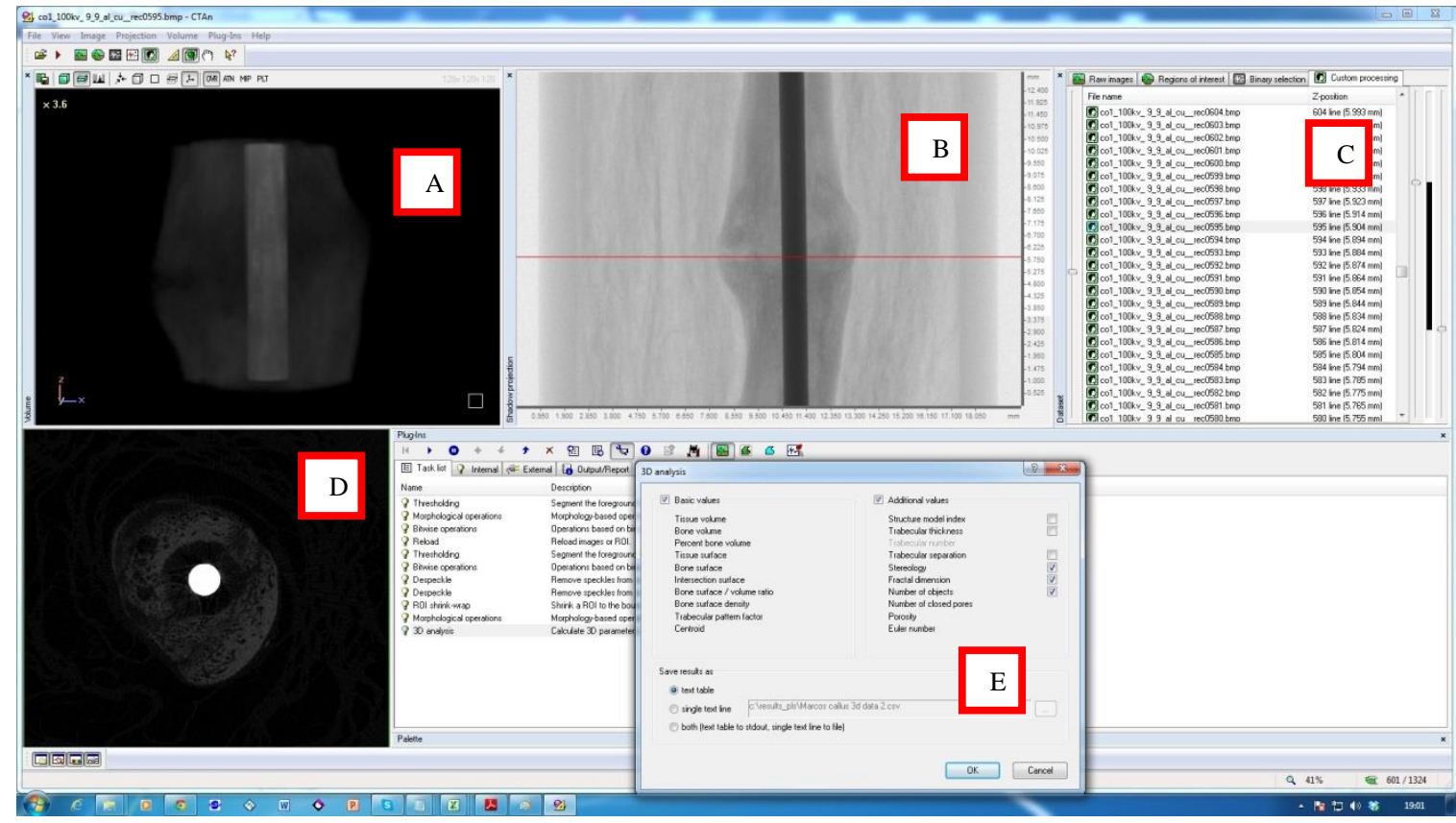

Figura 61 - Escolha dos parâmetros morfométricos a serem calculados.

Etapa 18: Salvar as imagens digitalizadas das seções transversais da amostra e da ROI através do plug-in "Image Map" em duas sub-pastas da pasta que contem a reconstrução microtomográfica da amostra. A figura 61 mostra uma das seções digitalizadas da amostra L08 salva na primeira subpasta. A figura 62 mostra uma das seções digitalizadas da ROI da seção da figura 62 salva na segunda subpasta.

Neste estudo não foi possível separar o tecido ósseo de reparo (calo) do tecido ósseo original. Contatos sobre essa dificuldade foram realizados com o Dr. Phil Salmon, cientista de aplicação da Bruker, que mencionou ser a resolução $(9.92 \mu \mathrm{m})$ elevada utilizada no escaneamento das amostras a causa da não separação. As figuras 62 e 63 comprovam essa dificuldade. Imagens 2D e 3D de uma mesma amostra foram obtidas através do software Mimics (versão 16.0.0.235 / 64bits, Materialise, Bélgica). Nas janelas A, B e C da figura 62 os pixels do intervalo 32 - 70 são mostrados em amarelo. Nas janelas A, B e C da figura 63 os pixels do intervalo 24 - 27 são mostrados em azul. Na janela D das figuras 62 e 63 observam-se os níveis de cinza e na janela E a mesma reconstrução 3D da amostra apesar dos diferentes níveis de cinza utilizados. 

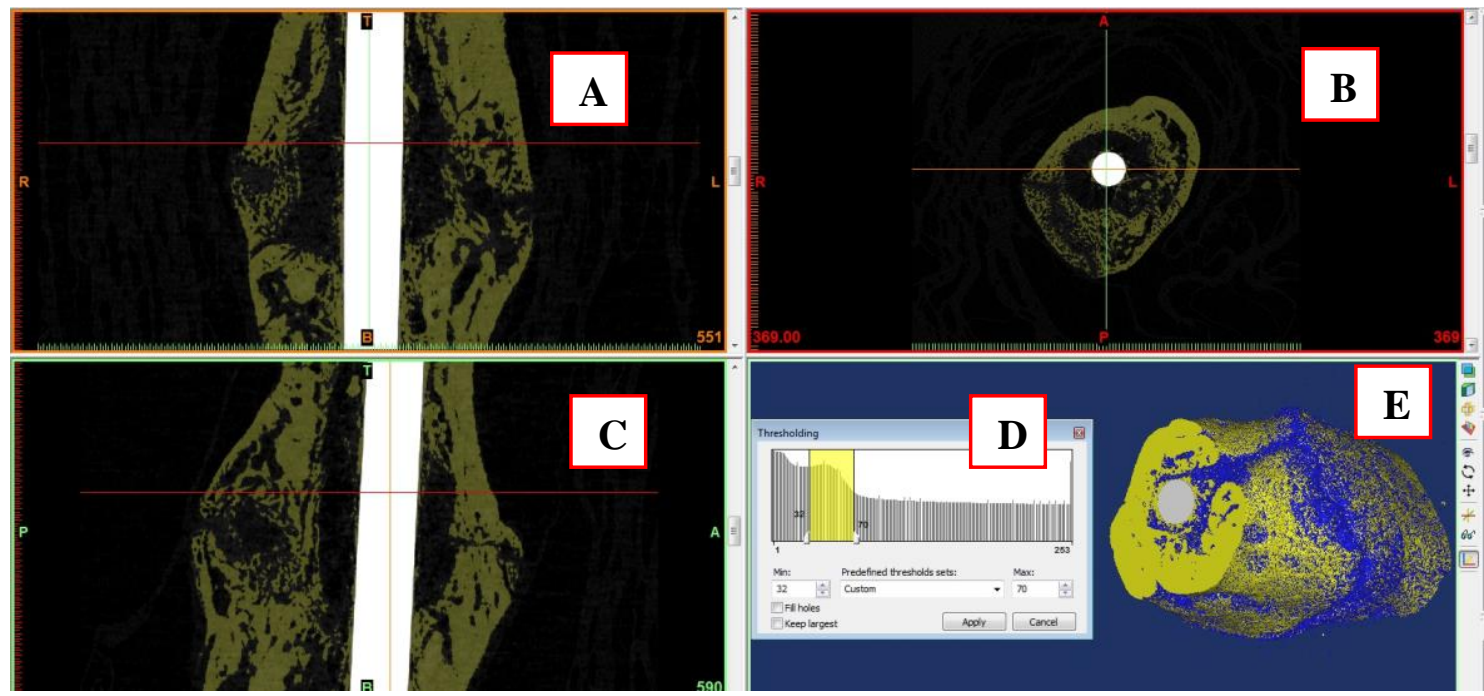

Figura 62 - Separação do tecido ósseo neoformado do tecido normal com níveis de cinza de 32 - 70.
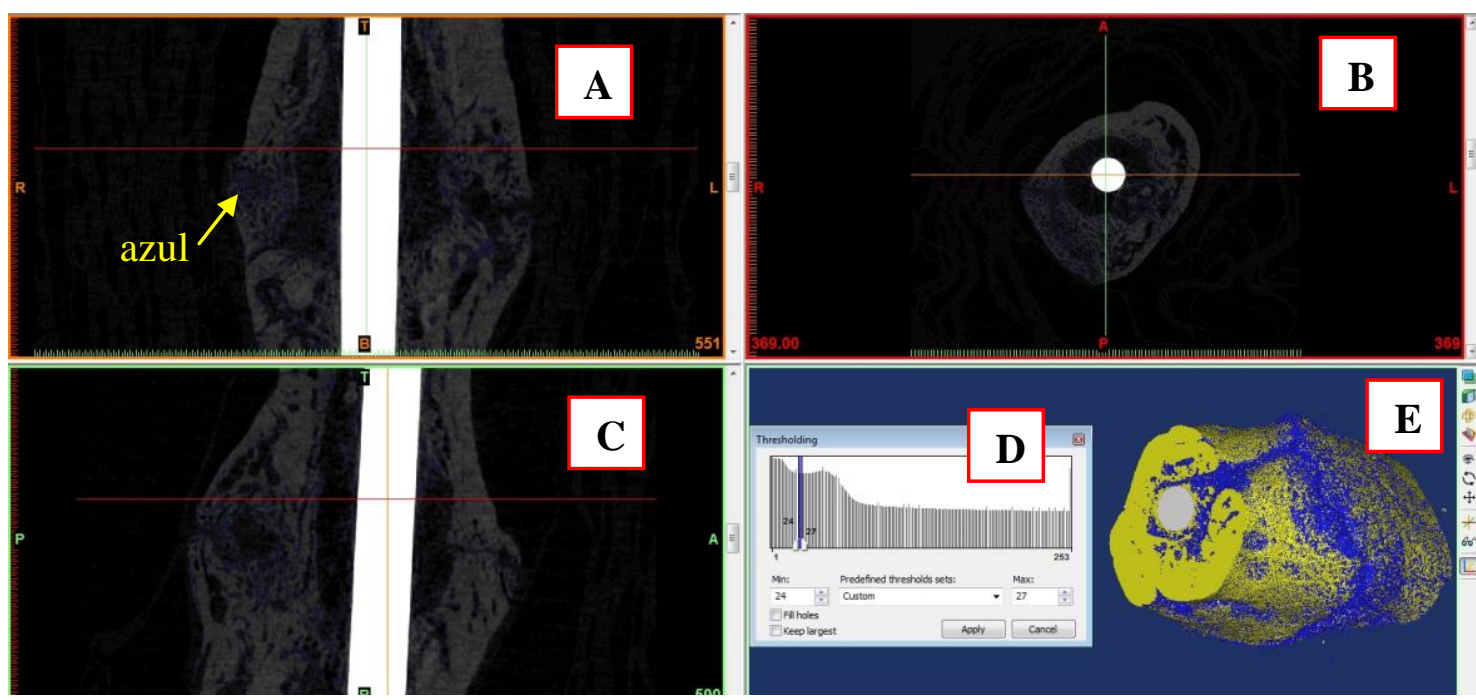

Figura 63 - Separação do tecido ósseo neoformado do tecido normal com níveis de cinza de 24 - 27.

Diante desse contexto, os volumes de interesse utilizados na análise microtomográfica por raio-x contiveram o calo e o tecido normal, conforme descrito por Salmo et al. (2012).

\subsection{Histologia e Histomorfometria}

A análise histomorfométrica foi realizada no Laboratório de Investigação do Sistema Músculo-Esquelético - Laboratório de Biomecânica, IOT - HC FMUSP (São Paulo, SP), após a $\mu \mathrm{CT}$. 


\subsubsection{Avaliação histológica do calo ósseo}

As amostras ósseas que estavam fixadas, em solução de formalina $10 \%$, foram submetidas à descalcificação com ácido nítrico 10\%. Após a descalcificação, as peças foram submetidas a cortes em sentido coronal (Figura 64). Os cortes foram submetidos à rotina histológica que consistiu na desidratação em série crescente de álcoois e clareamento em xilol. Posteriormente foram emblocadas em parafina. Os cortes histológicos foram obtidos dos blocos de parafina, com $5 \mu \mathrm{m}$ de espessura e foram corados pelo Hematoxilina-Eosina (HE) e Tricrômico de Masson.

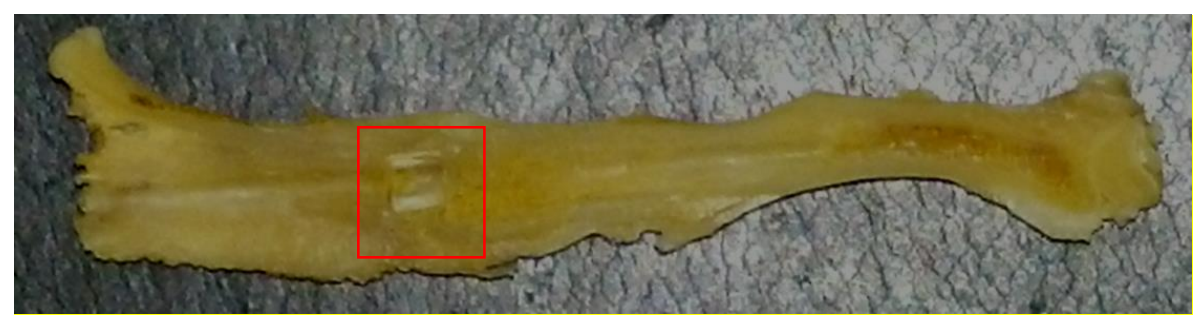

Figura 64- Corte em sentido coronal da amostra evidenciando a presença do espaçador.

A avaliação das alterações histológicas foi realizada sob microscópio de luz (Carl Zeiss, Oberkachen, Alemanha) e os achados foram documentados em fotografia.

\subsubsection{Avaliação Histomorfométrica do calo ósseo}

As lâminas coradas pelo Tricrômico de Masson foram analisadas sob microscópio de luz Zeiss ${ }^{\circledR}$ e a avaliação quantitativa dos componentes do calo ósseo foi realizada com auxílio de Sistema Analisador de Imagem (Kontron Eletronic 300, ZEISS ${ }^{\circledR}$ ).

A estação de trabalho era composta por microscópio Zeiss trinocular, uma vídeocâmera colorida (SONY CCD - Iris $^{\circledR}$ ) com placa digitalizadora de imagens, um microcomputador com processador Pentium ${ }^{\circledR} 133 \mathrm{MHz}$, IBM-PC compatível, operando em ambiente Windows $95^{\circledR}-32$ bits.

As imagens obtidas no total de campos microscópicos que compõem o calo ósseo foram digitalizadas com auxílio do software, permitindo a possibilidade de compartilhamento de dados com a planilha eletrônica (Microsoft Excel ${ }^{\circledR}$ ). A utilização deste programa proporcionou a análise, o tratamento, a interpretação e a obtenção de valores de mensuração das estruturas. A transmissão óptica foi quantificada a fim de se processar e analisar a imagem 
e para que esta fosse quantificada em suas medidas originais, optou-se por transformar a medida da imagem digitalizada, o pixel, em medida micrometrada. Para tal utilizou-se a calibração de pixel em micrômetros. Após aquisição da imagem através de uma câmera CCD, utilizou-se o recurso de "thereshold" para marcar as estruturas a serem quantificadas.

Para análise da fração de área dos tecidos que compõe o calo ósseo, a área de cada uma delas (fibrose, cartilagem e osso) foi obtida pela delimitação do tecido através da ferramenta de traço livre do Programa Kontron, sendo expressa em micrômetros quadrados. A somatória das áreas de cada um destes tecidos compôs a área total de calo ósseo analisado e assim obteve-se a porcentagem de cada uma comparando com a área total. Cada campo microscópico foi avaliado com objetiva de 4 aumentos e ocular de 10 aumentos. Os resultados foram arquivados em planilha Excel ${ }^{\circledR}$ para posterior análise estatística.

\subsection{Análise estatística}

Os dados foram expressos em médias e desvio padrão, organizados em tabelas e ilustrados em gráficos. A normalidade da distribuição dos dados foi analisada pelo teste de ShapiroWilk e a homocedasticidade das variâncias pelo teste de Levene. Foi utilizada a análise de variância (ANOVA One-Way) para comparação intergrupos. Resultados significativos foram submetidos ao teste de post-hoc de Tukey. O software Statistica for Windows Release 7 (Statsoft Inc., Tulsa, OK, USA) foi utilizado para análise estatística. O nível de significância estatística adotado foi de $5 \%(\mathrm{p}<0.05)$. 


\section{RESULTADOS}

\subsection{Avaliação Radiográfica Cega do Reparo Ósseo por Microtomografia por Raio-X}

Os escores da fratura para cada amostra são mostrados na tabela 4. Os valores de média e desvio padrão dos escores das fraturas foram de $2.6 \pm 1.14$ para o grupo controle; $2.83 \pm$ 0.98 para o grupo Laser; $3.16 \pm 0.75$ para o grupo US e; $3.00 \pm 1.15$ para o grupo US+Laser.

Não foram constatadas diferenças significativas intergrupos (ANOVA one-way, $p \geq 0.05$ ) nos escores da avaliação qualitativa das fraturas.

Tabela 5: Avaliação Radiográfica Cega

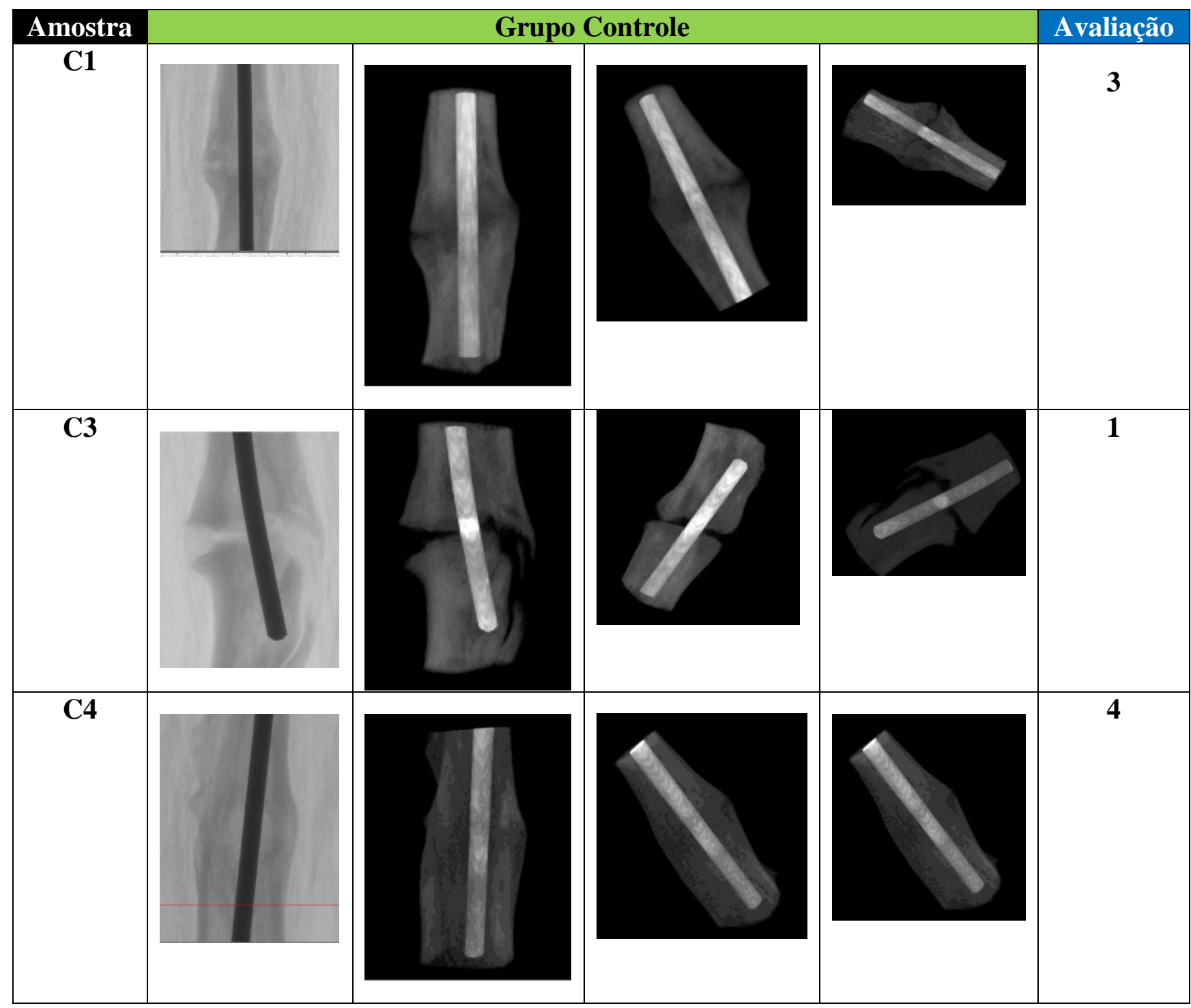




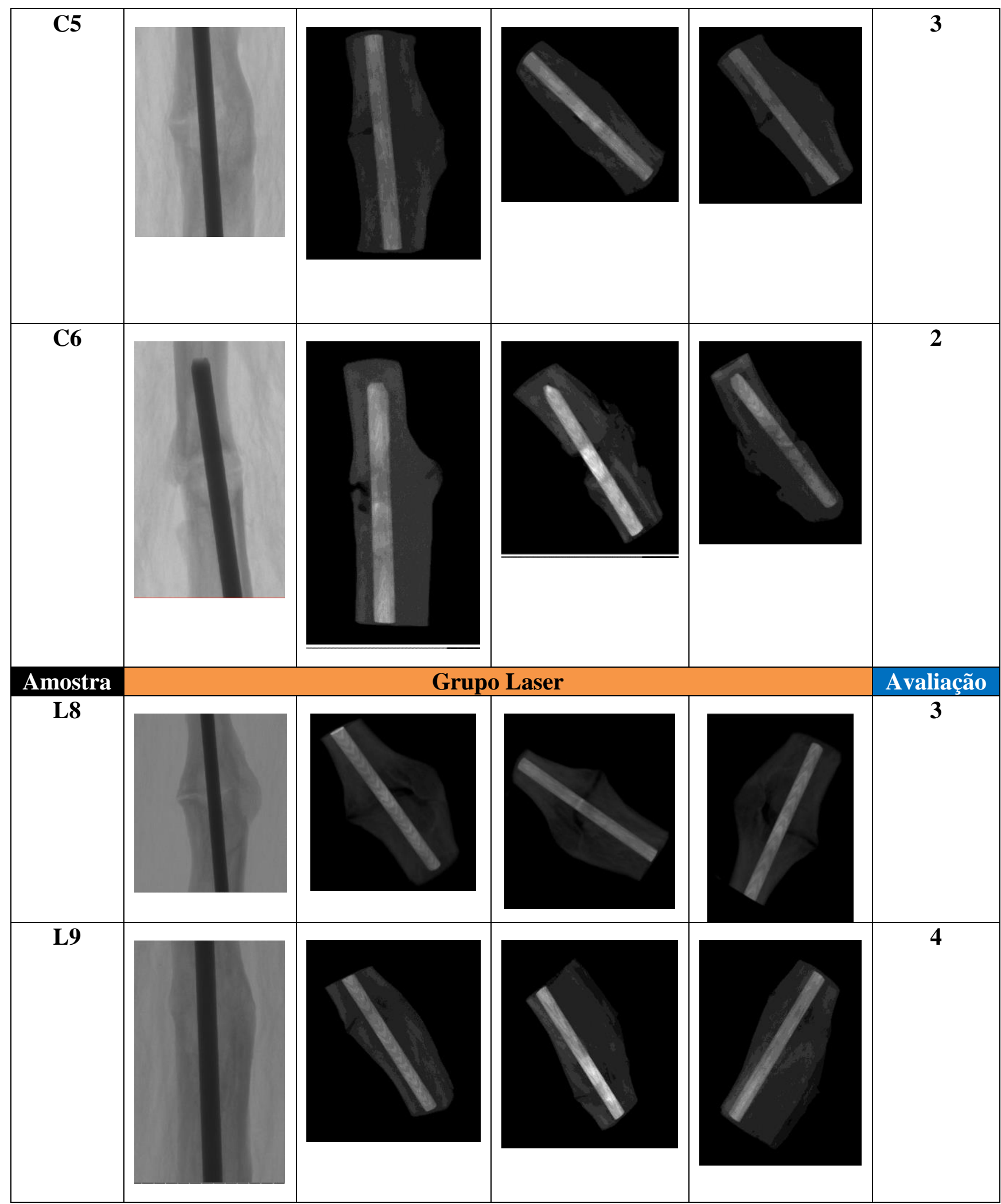


\begin{tabular}{l|l} 
Resultados & 84
\end{tabular}

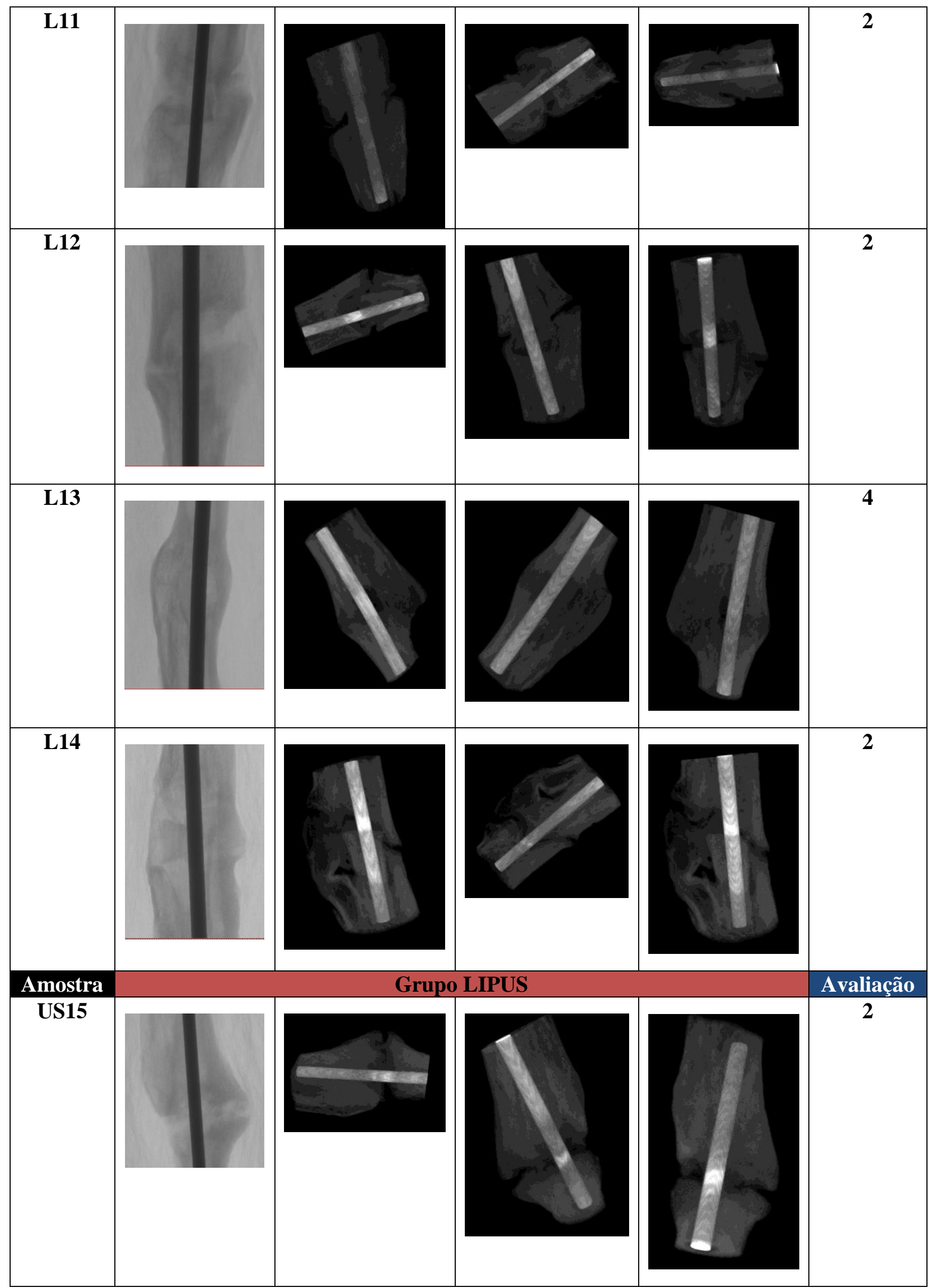




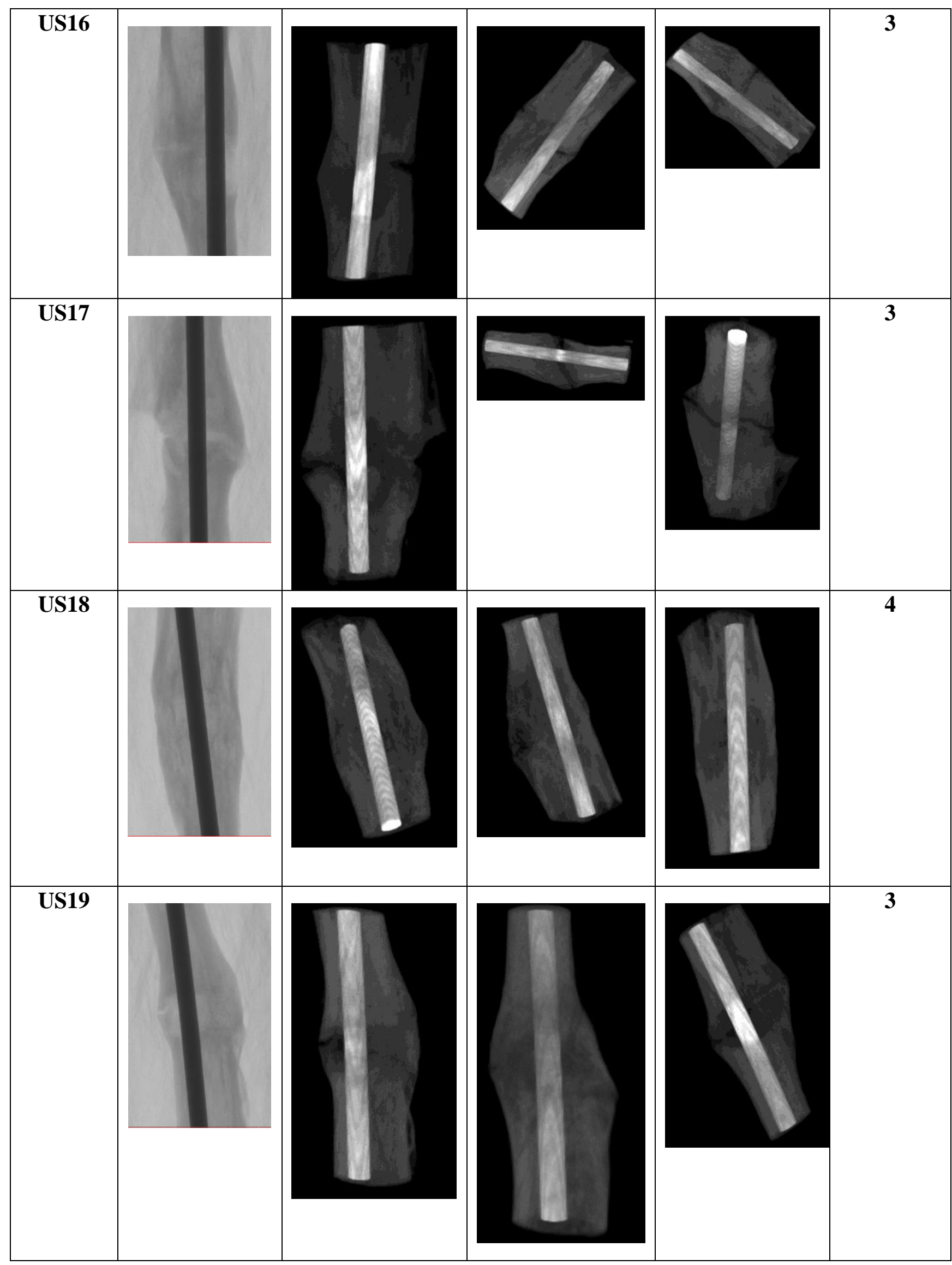


\begin{tabular}{l|l} 
Resultados & 86
\end{tabular}

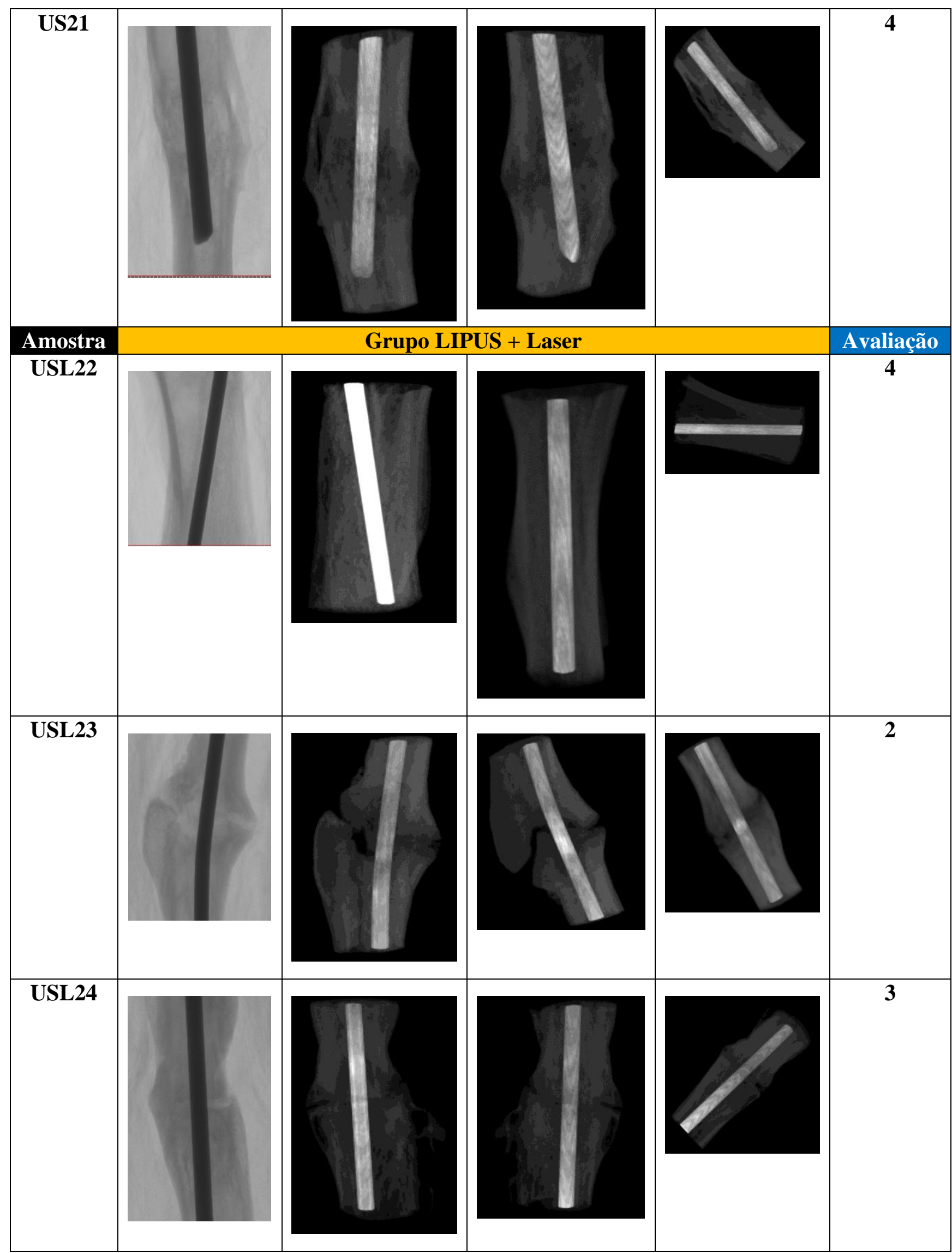


\begin{tabular}{l|l} 
Resultados & 87
\end{tabular}

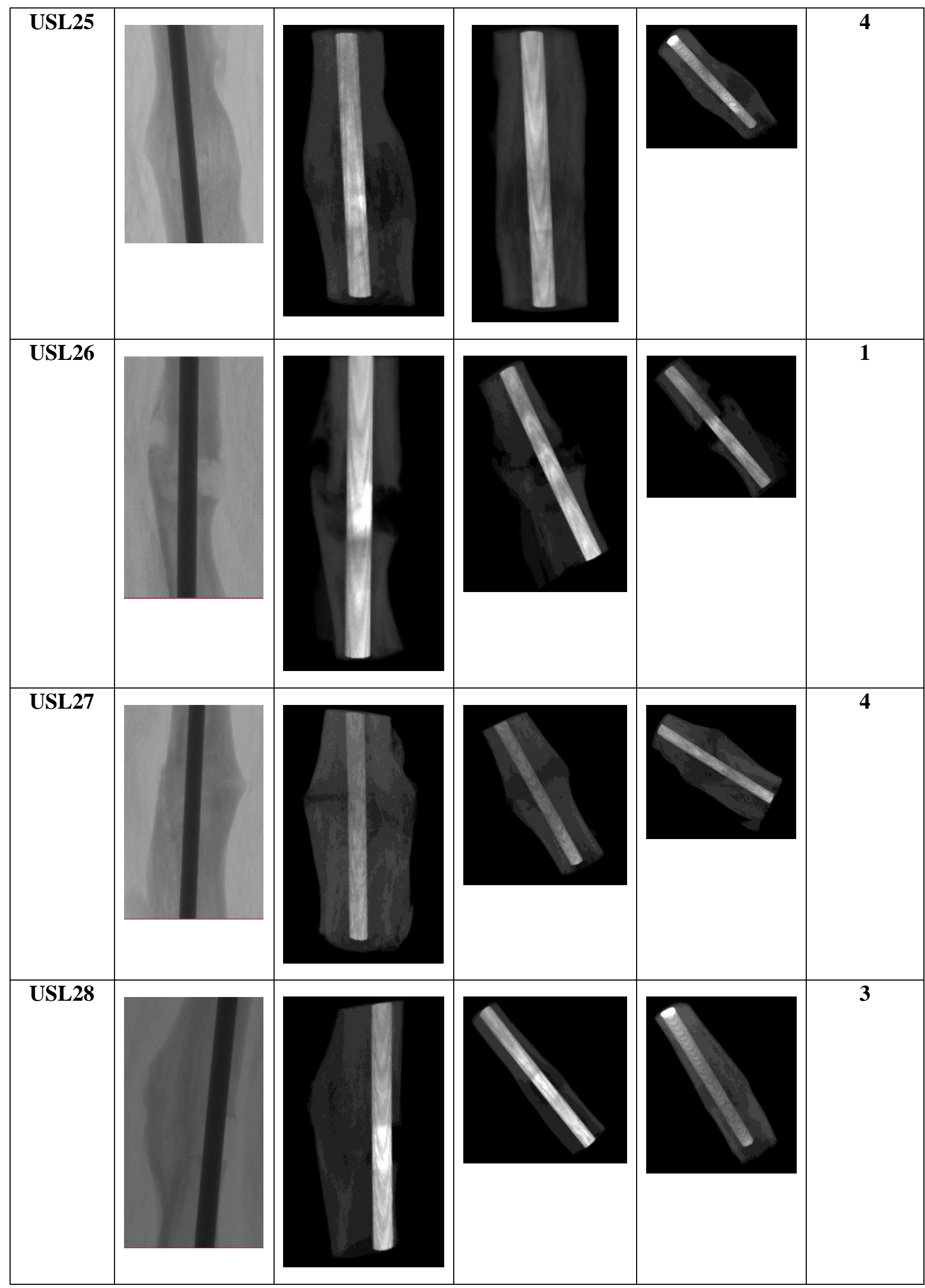


5.2 Visualização das reconstruções $2 D$ e 3D

As visualizações microtomográficas $2 \mathrm{D}$ e $3 \mathrm{D}$ da região do reparo ósseo foram realizadas através do software Mimics e estão mostradas na tabela 6, 7, 8 e 9.

Tabela 6 - Grupo Experimental Controle.

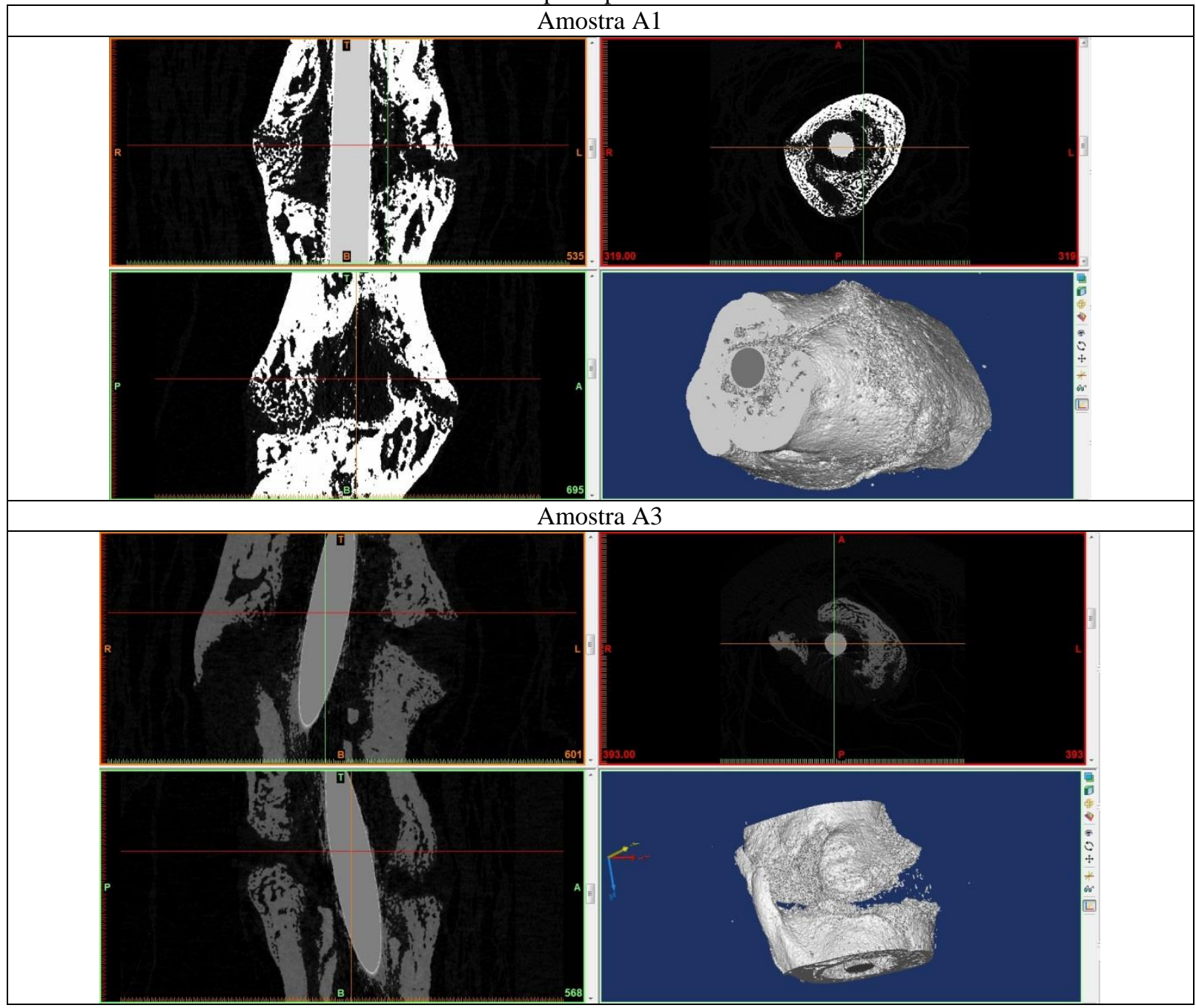


Tabela 6 (cont.) - Grupo Experimental Controle.

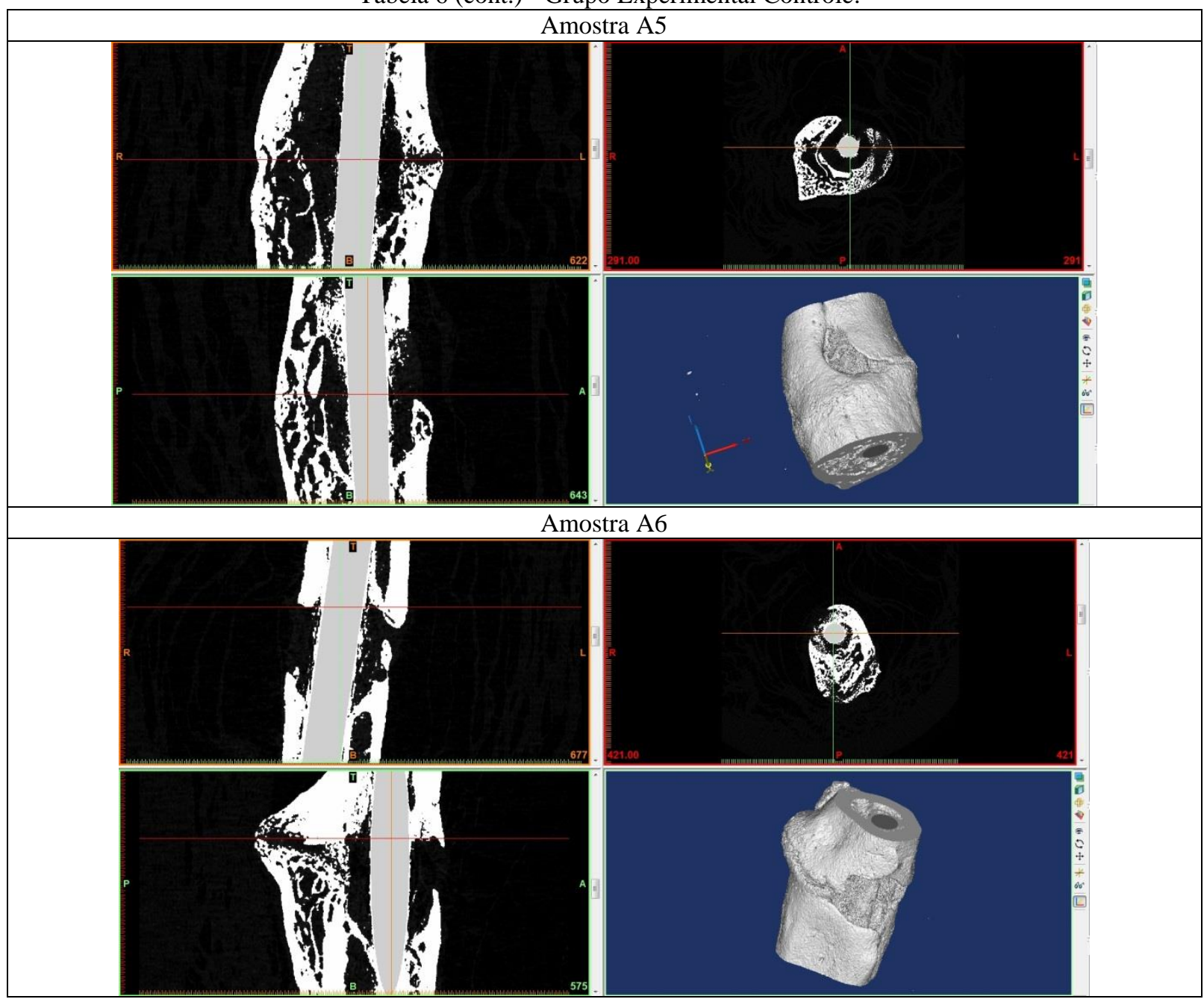

Tabela 7 - Grupo Experimental Laser

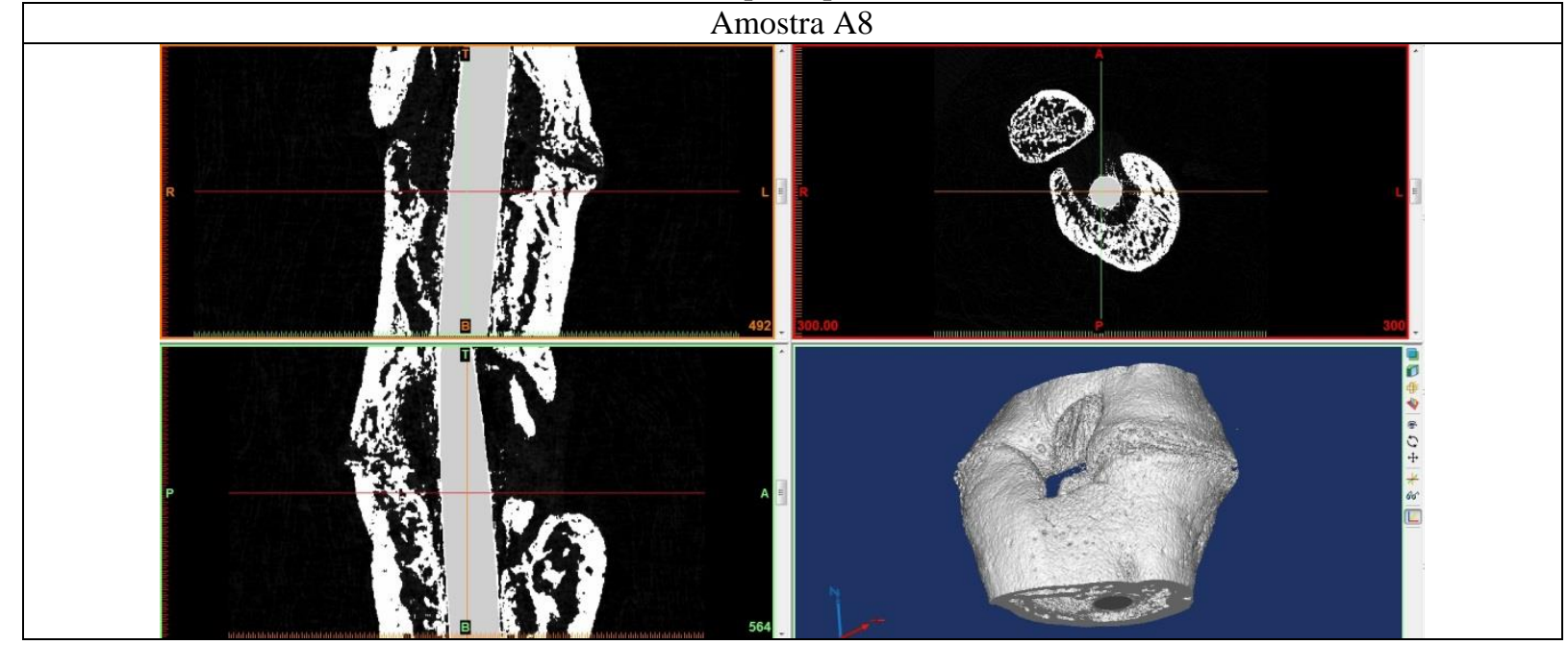


Tabela 7 (cont.) - Grupo Experimental Laser.

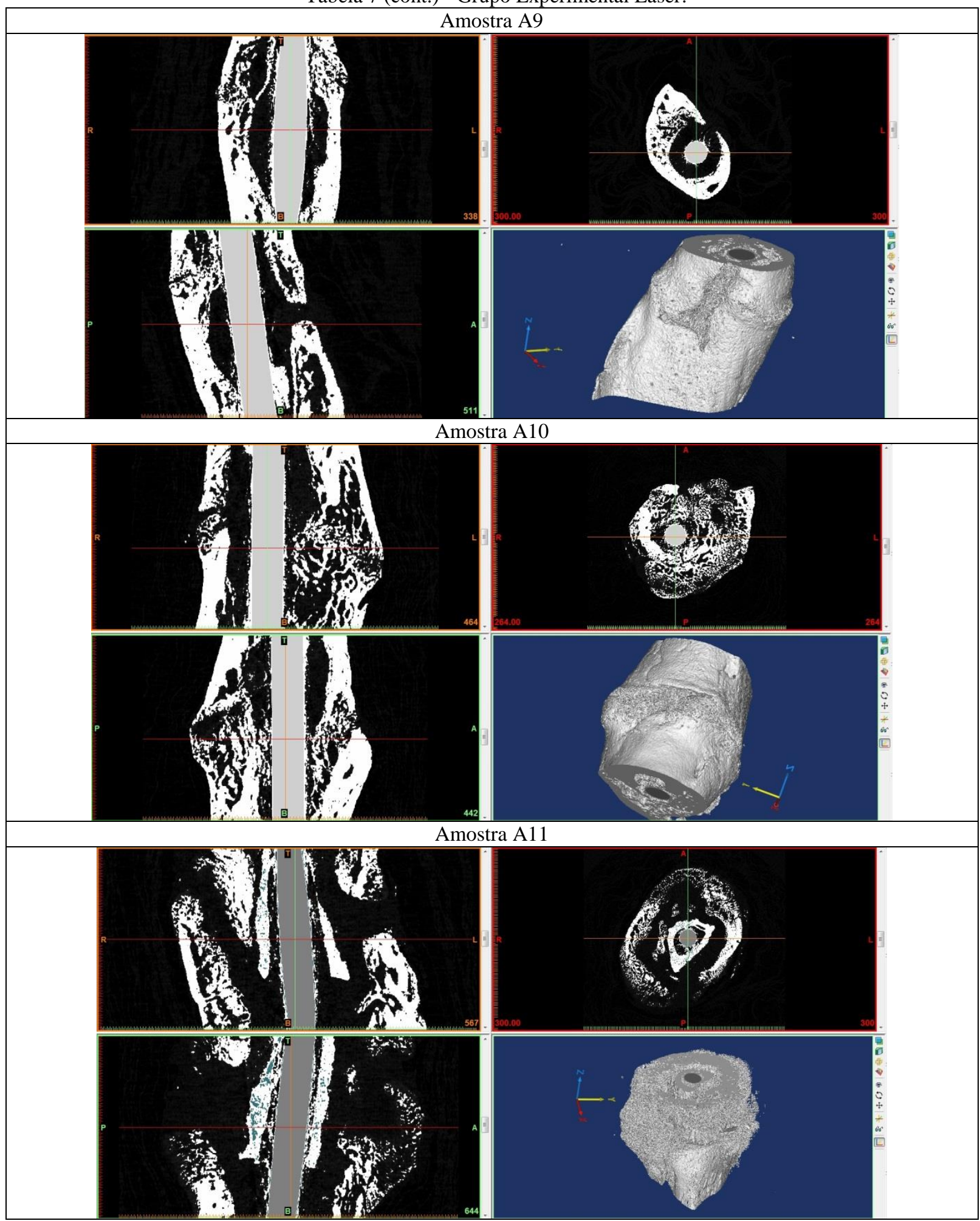


Tabela 7 (cont.) - Grupo Experimental Laser.

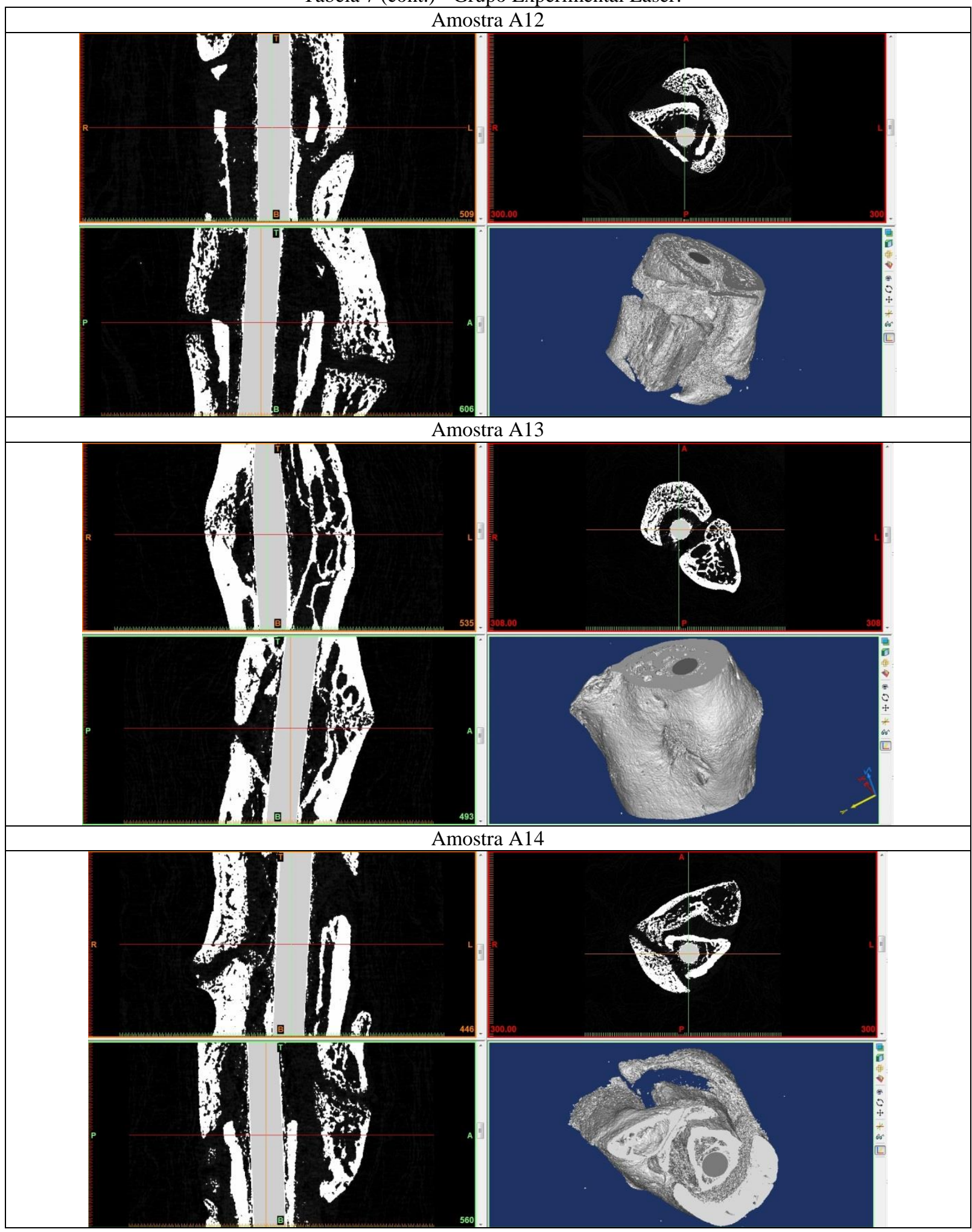


Tabela 8 - Grupo Experimental LIPUS

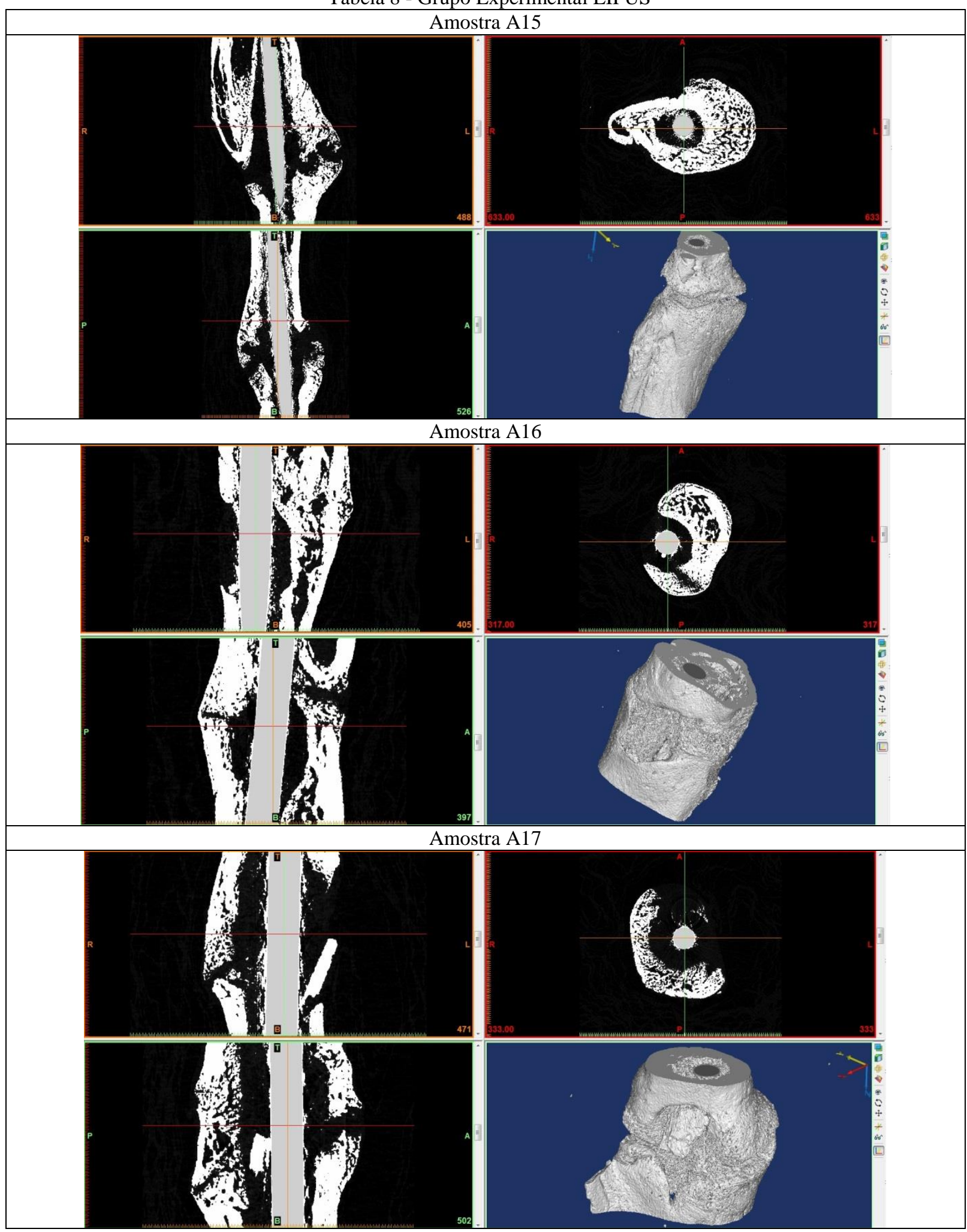


Tabela 8 (cont.) - Grupo Experimental LIPUS.

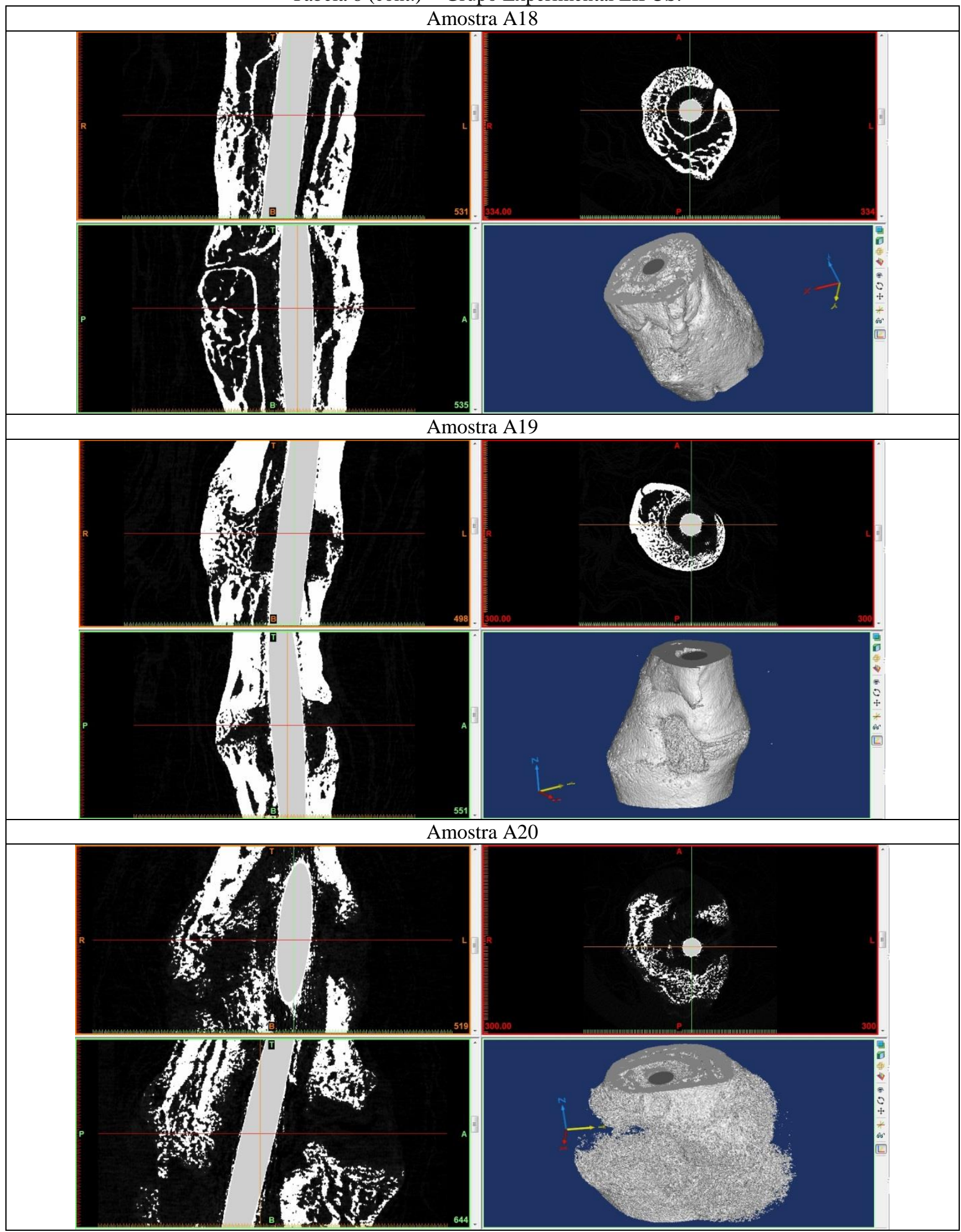


Tabela 8 (cont.) - Grupo Experimental LIPUS.

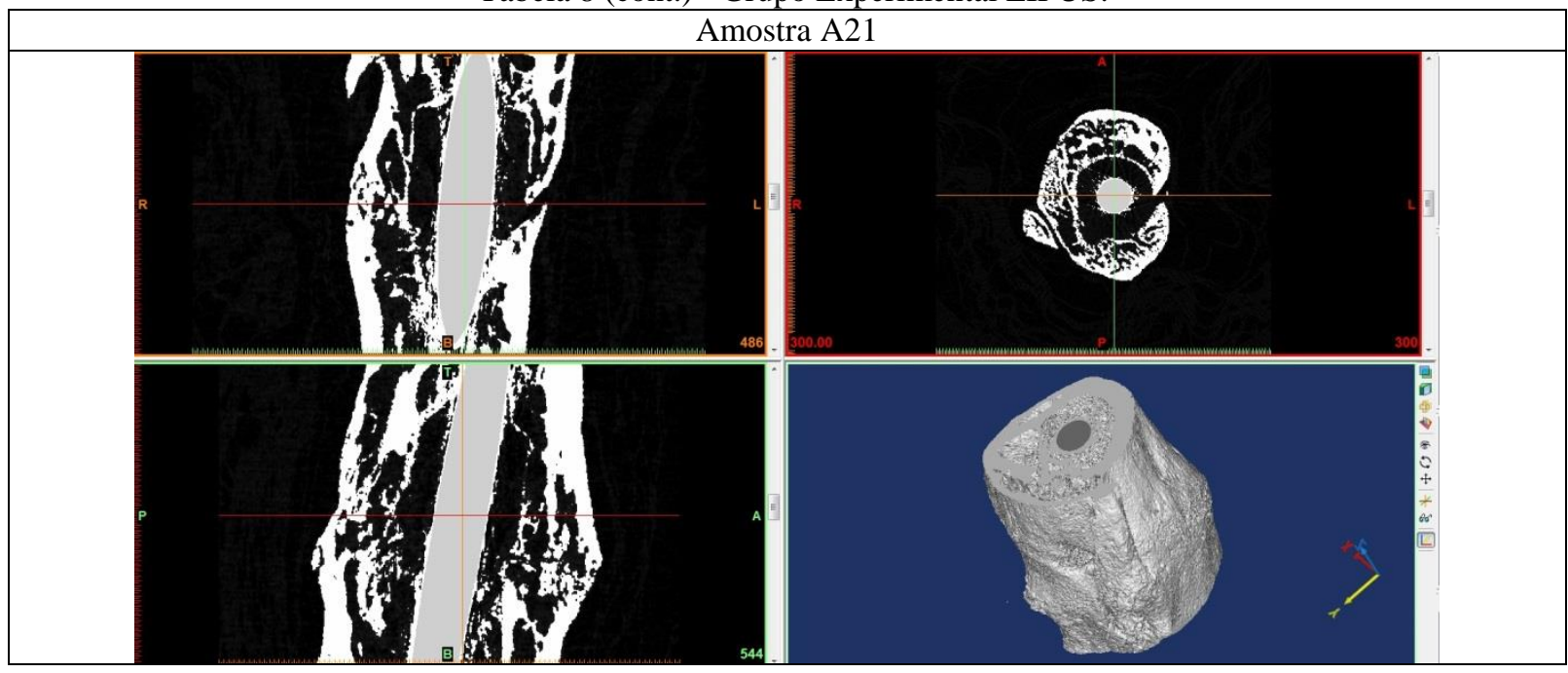

Tabela 9 - Grupo Experimental LIPUS e Laser.

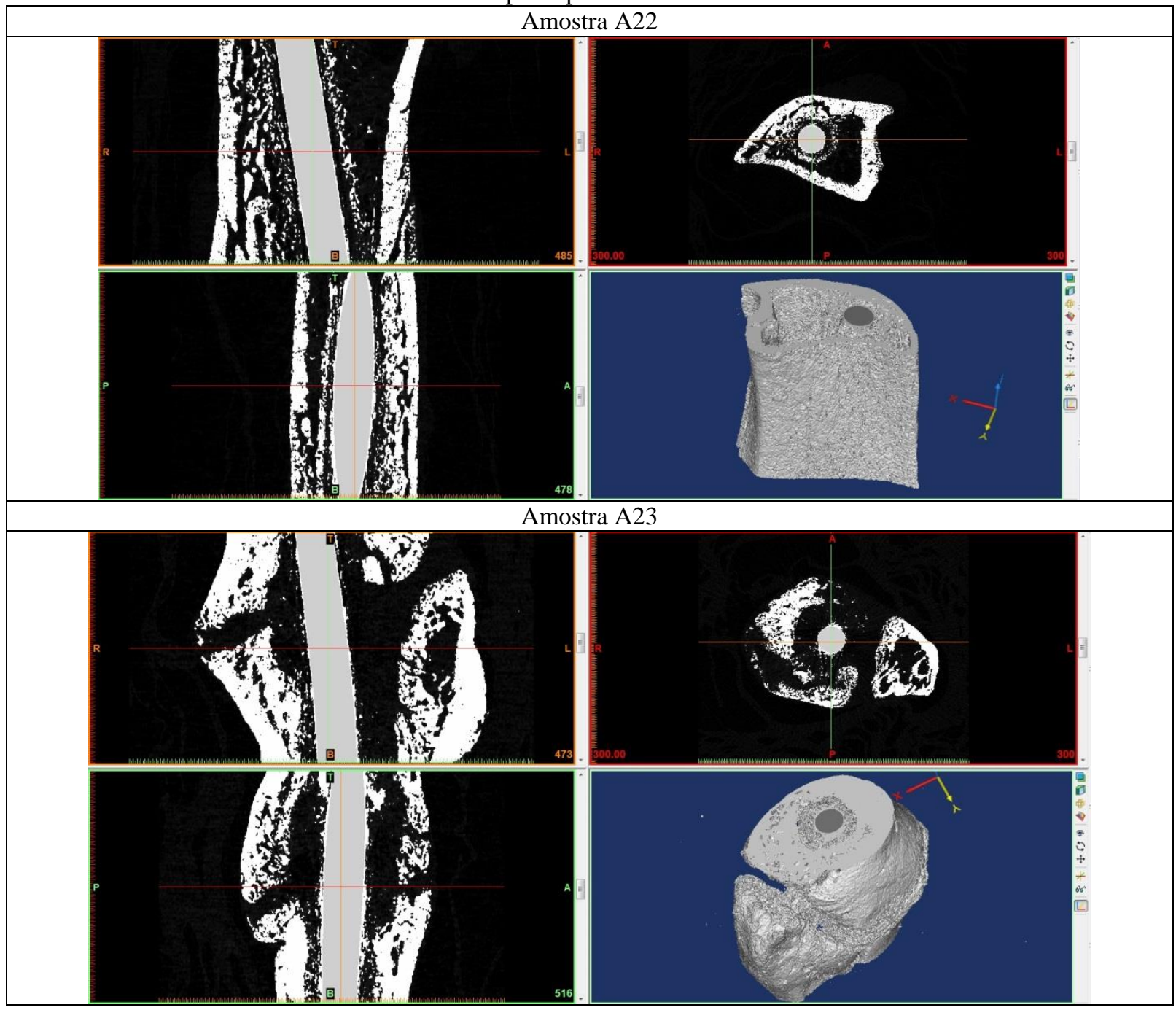


Tabela 9 (cont.) - Grupo Experimental LIPUS e Laser.

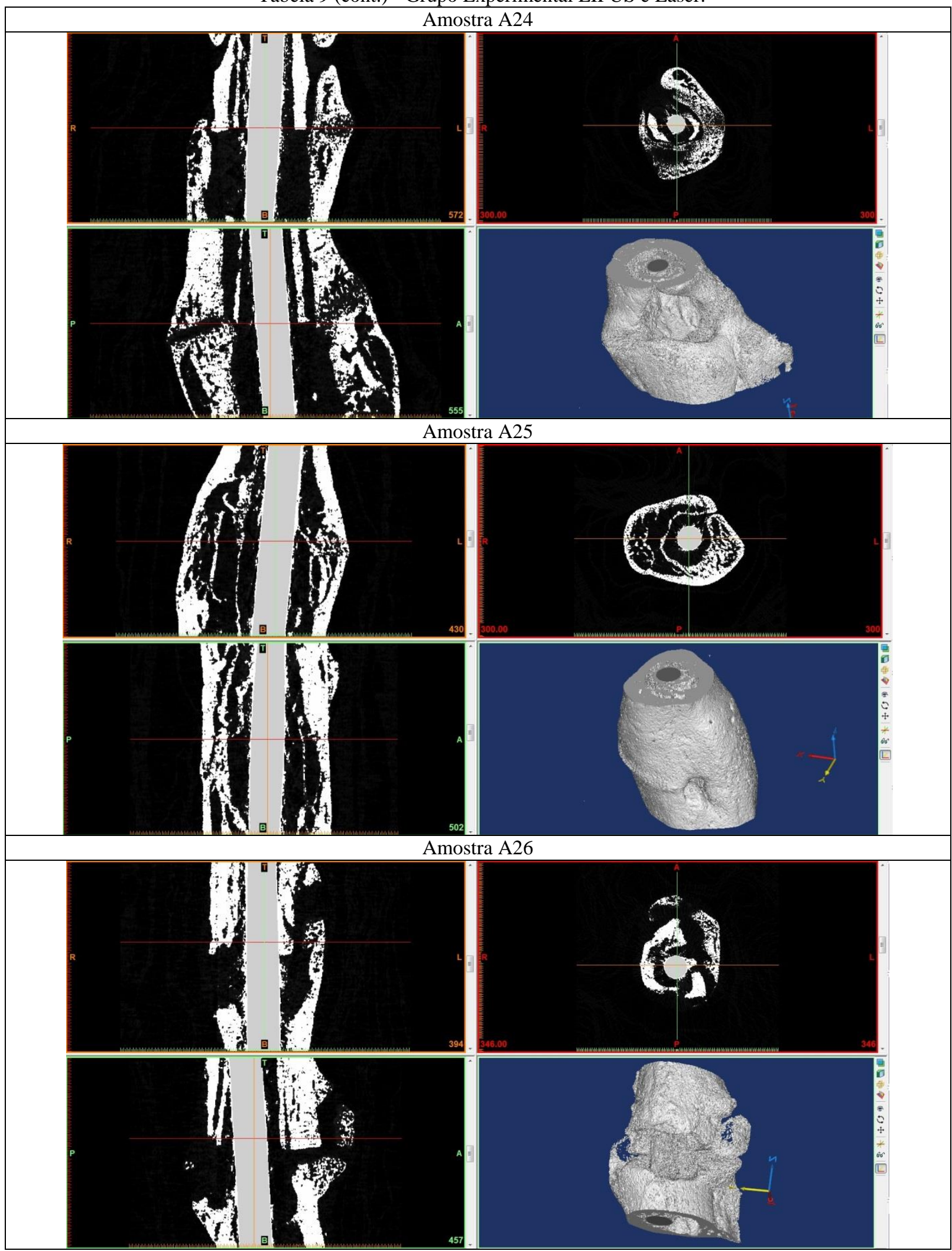


Tabela 9 (cont.) - Grupo Experimental LIPUS e Laser.

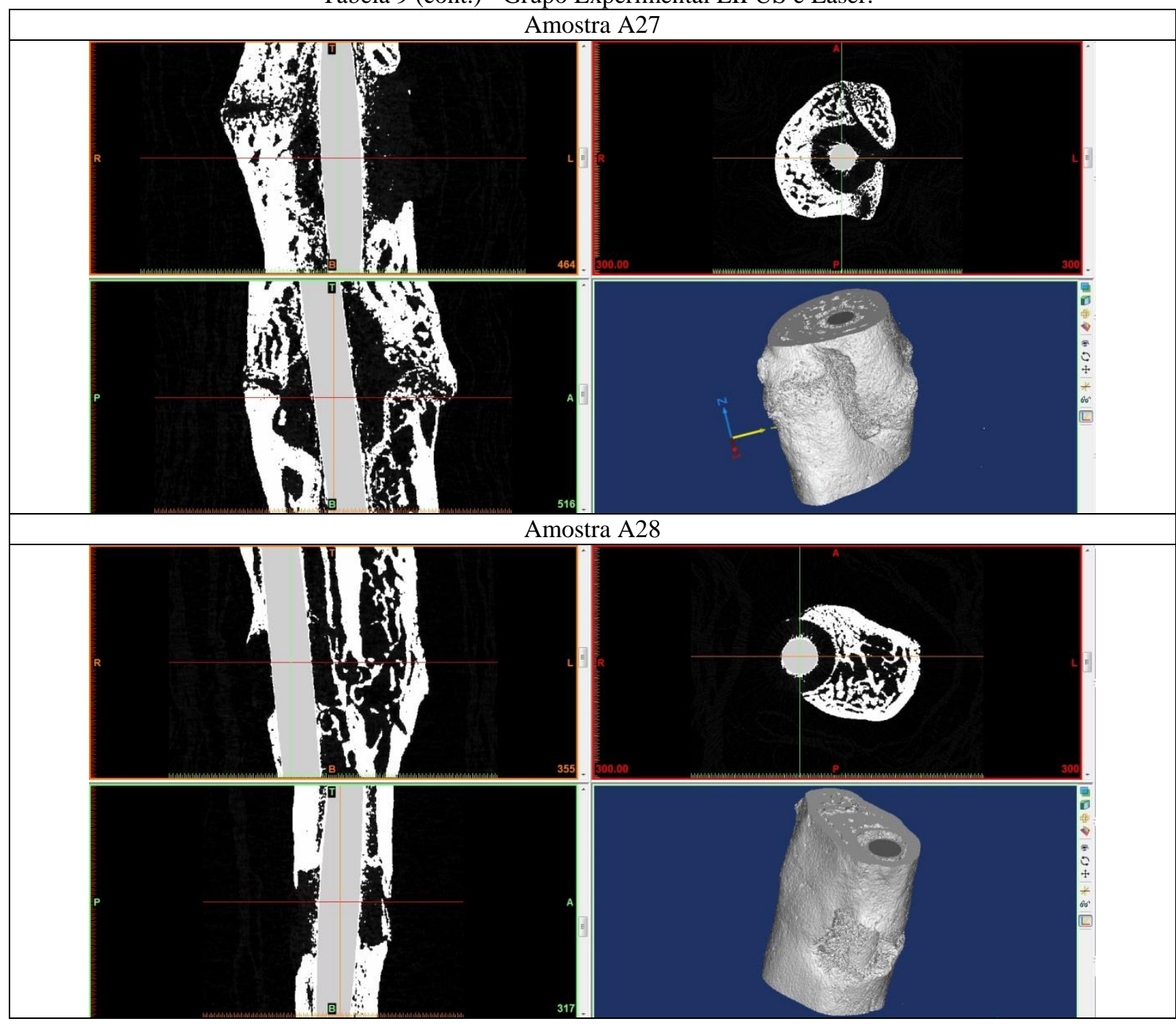

\subsection{Quantificação do Calo Ósseo}

Os resultados da microtomografia e da histomorfometria do calo ósseo podem ser observados, respectivamente, nas Tabelas 8 e 9. Foram constatadas diferenças significativas para o Fator Padrão Trabecular no grupo LIPUS+LASER comparado aos grupos LIPUS $(\mathrm{p}=0.02)$, LASER $(\mathrm{p}=0.02)$ e CONTROLE $(\mathrm{p}=0.01)$, para a Densidade de Conectividade no grupo LIPUS+LASER comparado ao grupo CONTROLE ( $\mathrm{p}=0.04)$ e para a Conectividade no grupo LASER comparado ao grupo CONTROLE (p=0.04). As Figuras 65, 66 e 67 mostram, respectivamente, as diferenças significativas intergrupo no Fator Padrão Trabecular, na Densidade de Conectividade e Conectividade. Diferenças significativas também foram obtidas para a porcentagem de fibrose [LIPUS+LASER x LASER $(\mathrm{p}=0.04)$ e podem ser 
observadas na figura 68. Entretanto, não foram constatadas diferenças significativas nas demais variáveis obtidas pela microtomografia e histomorfometria. As fotomicrografias ósseas podem ser observadas nas figuras $69,70,71$ e 72.

Tabela 10 - Médias e desvios padrão dos parâmetros ósseos morfométricos e topológicos obtidos

\begin{tabular}{|c|c|c|c|c|}
\hline & $\begin{array}{l}\text { CONTROLE } \\
\qquad(\mathrm{N}=5)\end{array}$ & $\begin{array}{l}\text { LASER } \\
(\mathrm{N}=6)\end{array}$ & $\begin{array}{l}\text { LIPUS } \\
(\mathrm{N}=6)\end{array}$ & $\begin{array}{c}\text { LIPUS + } \\
\text { LASER }(\mathbf{N}=7)\end{array}$ \\
\hline $\begin{array}{c}\text { Volume } \\
\left(\mathrm{TV}-\mathbf{m m}^{\mathbf{3}}\right)\end{array}$ & $\begin{array}{c}87.57 \pm \\
16.71\end{array}$ & $\begin{array}{c}122.89 \pm \\
44.90\end{array}$ & $\begin{array}{c}90.49 \pm \\
17.63\end{array}$ & $\begin{array}{c}89.38 \pm \\
27.25\end{array}$ \\
\hline $\begin{array}{l}\text { Volume Ósseo } \\
\left(\mathrm{BV}-\mathbf{m m}^{\mathbf{3}}\right)\end{array}$ & $\begin{array}{c}47.36 \pm \\
8.17\end{array}$ & $\begin{array}{c}59.97 \pm \\
19.08\end{array}$ & $\begin{array}{c}49.29 \pm \\
7.24\end{array}$ & $\begin{array}{c}45.57 \pm \\
13.58\end{array}$ \\
\hline $\begin{array}{c}\text { BV/TV } \\
(\%)\end{array}$ & $\begin{array}{c}54.27 \pm \\
2.43\end{array}$ & $\begin{array}{c}49.95 \pm \\
7.40\end{array}$ & $\begin{array}{c}53.33 \pm \\
7.72\end{array}$ & $\begin{array}{c}51.64 \pm \\
6.79\end{array}$ \\
\hline $\begin{array}{c}\text { Área Superficial } \\
\left(\mathrm{TS}-\mathbf{m m}^{\mathbf{2}}\right)\end{array}$ & $\begin{array}{c}151.74 \pm \\
33.24\end{array}$ & $\begin{array}{c}238.34 \pm \\
80.17\end{array}$ & $\begin{array}{c}167.89 \pm \\
56.07\end{array}$ & $\begin{array}{c}167.49 \pm \\
45.80\end{array}$ \\
\hline $\begin{array}{c}\text { Área Superficial Óssea } \\
\left(\mathrm{BS}-\mathbf{m m}^{\mathbf{2}}\right)\end{array}$ & $\begin{array}{c}841.92 \pm \\
253.20\end{array}$ & $\begin{array}{c}1279.74 \pm \\
519.88\end{array}$ & $\begin{array}{c}924.82 \pm \\
260.33\end{array}$ & $\begin{array}{c}983.04 \pm \\
385.87\end{array}$ \\
\hline $\begin{array}{l}\mathrm{BS} / \mathrm{BV} \\
\left(\mathrm{mm}^{-1}\right)\end{array}$ & $\begin{array}{c}17.47 \pm \\
2.53\end{array}$ & $\begin{array}{c}21.36 \pm \\
5.54\end{array}$ & $\begin{array}{c}18.53 \pm \\
2.64\end{array}$ & $\begin{array}{c}21.26 \pm \\
4.78\end{array}$ \\
\hline $\begin{array}{c}\text { Fator Padrão Trabecular } \\
\left(\text { Tb.Pf }-\mathbf{m m}^{-1}\right)\end{array}$ & $\begin{array}{c}-17.62 \pm \\
4.61\end{array}$ & $\begin{array}{c}-19.30 \pm \\
4.51\end{array}$ & $\begin{array}{c}-21,49 \pm \\
5.45\end{array}$ & $\begin{array}{c}-28.04 \pm \\
7.95 *\end{array}$ \\
\hline $\begin{array}{l}\text { Dimensão Fractal } \\
\text { (FD) }\end{array}$ & $\begin{array}{c}2.27 \pm \\
0.04\end{array}$ & $\begin{array}{c}2.29 \pm \\
0.03\end{array}$ & $\begin{array}{c}2.30 \pm \\
0.05\end{array}$ & $\begin{array}{c}2.32 \pm \\
0.08\end{array}$ \\
\hline $\begin{array}{c}\text { Densidade de } \\
\text { Conectividade } \\
\left(\text { Conn.Dn }-\mathbf{m m}^{-3}\right)\end{array}$ & $\begin{array}{c}193.17 \pm \\
79.10\end{array}$ & $\begin{array}{c}252.33 \pm \\
78.80\end{array}$ & $\begin{array}{c}231.31 \pm \\
88.37\end{array}$ & $\begin{array}{l}289.80 \pm \\
111.31 *\end{array}$ \\
\hline
\end{tabular}


Tabela 10 (cont.) - Médias e desvios padrão dos parâmetros ósseos morfométricos e topológicos

\begin{tabular}{|c|c|c|c|c|}
\hline $\begin{array}{c}\text { Conectividade } \\
\text { (Conn) }\end{array}$ & $\begin{array}{c}17516.20 \pm \\
9467.01\end{array}$ & $\begin{array}{c}32371.16 \pm \\
20689.39 *\end{array}$ & $\begin{array}{c}21088.50 \pm \\
10356.42\end{array}$ & $\begin{array}{c}27206.71 \pm \\
\end{array}$ \\
$\begin{array}{c}\text { Densidade Mineral Média } \\
\text { (BMDBV - mm }{ }^{3} \text { ) }\end{array}$ & $4.03 \pm$ & $3.69 \pm$ & $4.11 \pm$ & $3.98 \pm$ \\
\hline Massa Mineral & 0.19 & 0.59 & 0.62 & 0.58 \\
Aproximada (Ma-mg) & $190.66 \pm$ & $221.98 \pm$ & $202.89 \pm$ & $210.00 \pm$ \\
& 31.71 & 89.63 & 40.22 & 88.56 \\
Densidade Mineral Média & $0.74 \pm$ & $0.68 \pm$ & $0.76 \pm$ & $0.73 \pm$ \\
Normalizada (BMDBV / & 0.03 & 0.11 & 0.12 & 0.10 \\
BMDcort) & & & & \\
\hline
\end{tabular}

* Significante diferença intergrupo (ANOVA one-way com pos-hoc Tukey, p<0.05).

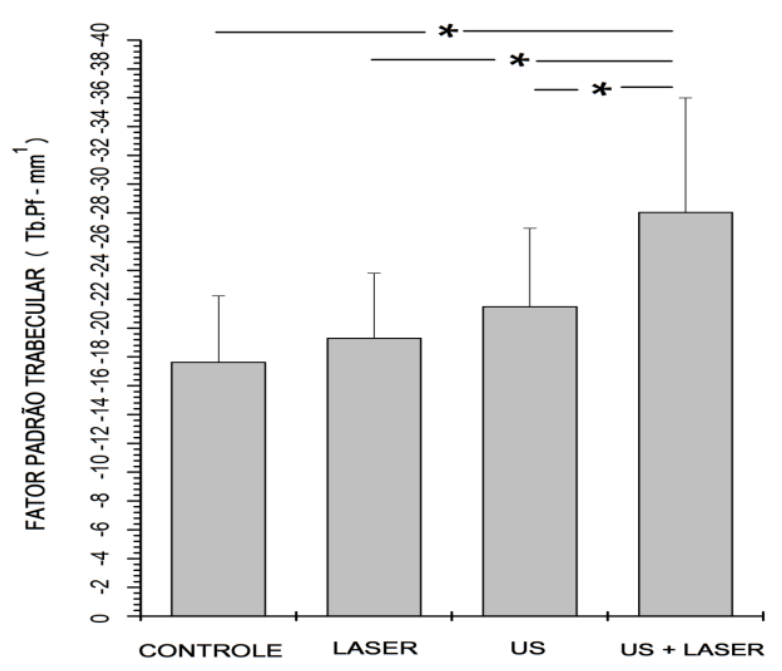

FIGURA 65 - Fator Padrão Trabecular no calo ósseo obtido por microtomografia.

* Significante diferença intergrupo (ANOVA one-way com pos-hoc Tukey, p<0.05). 


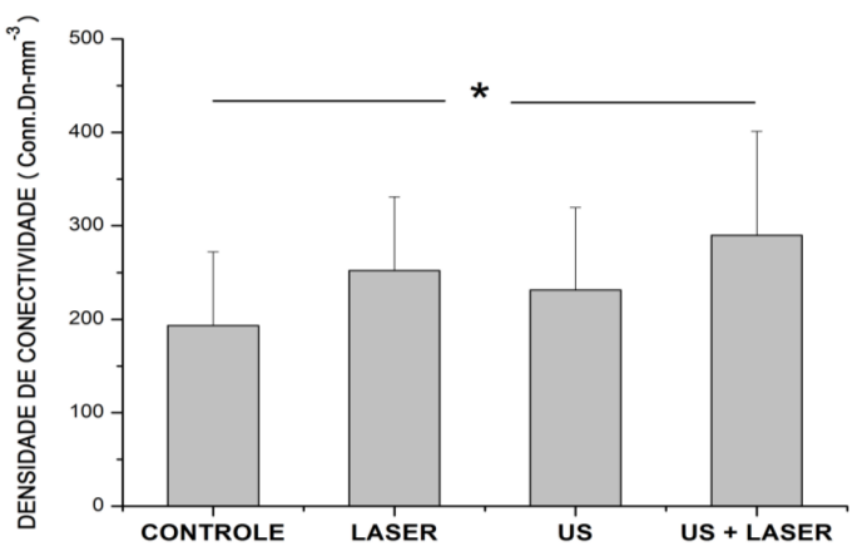

FIGURA 66 - Densidade de Conectividade no calo ósseo obtido por microtomografia.

* Significante diferença intergrupo (ANOVA one-way com pos-hoc Tukey, $\mathrm{p}<0.05$ ).

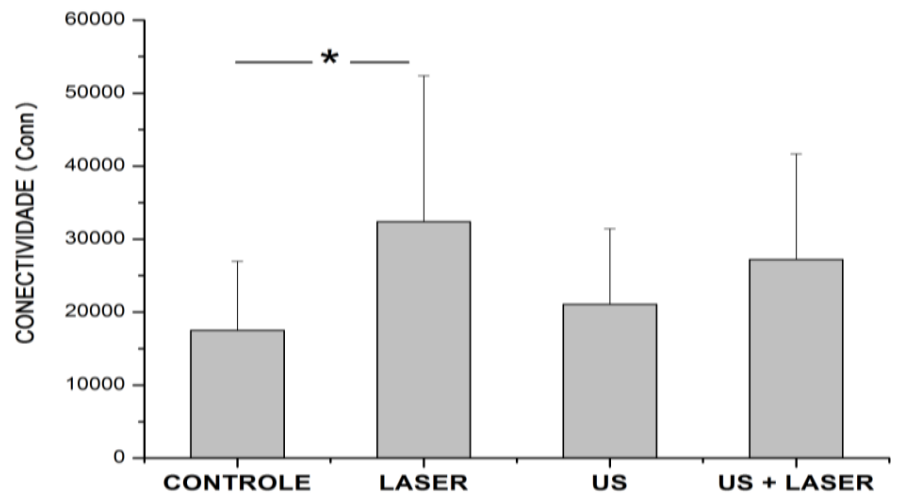

FIGURA 67 - Conectividade no calo ósseo obtido por microtomografia. * Significante diferença intergrupo (ANOVA one-way com pos-hoc Tukey, p<0.05).

TABELA 11 - Médias e desvios padrão dos parâmetros ósseos obtidos por histomorfometria.

\begin{tabular}{|c|c|c|c|c|}
\hline & $\begin{array}{c}\text { CONTROLE } \\
(\mathbf{N = 5})\end{array}$ & $\begin{array}{c}\text { LASER } \\
\mathbf{( N = 6 )}\end{array}$ & $\begin{array}{c}\text { LIPUS } \\
(\mathbf{N = 6})\end{array}$ & $\begin{array}{c}\text { LIPUS + } \\
\text { LASER (N=7) }\end{array}$ \\
\hline $\begin{array}{c}\text { Área Óssea } \\
\left(\boldsymbol{\mu m}^{\mathbf{2}}\right)\end{array}$ & $\begin{array}{c}13119417 \pm \\
4787616\end{array}$ & $\begin{array}{c}11872576 \pm \\
3703663\end{array}$ & $\begin{array}{c}11611998 \pm \\
6988946\end{array}$ & $\begin{array}{c}12987621 \pm \\
3657718\end{array}$ \\
\hline Área Cartilaginosa & $2997216 \pm$ & $4051381 \pm$ & $3162997 \pm$ & $4159189 \pm$ \\
$\left(\boldsymbol{\mu \mathbf { m } ^ { 2 } )}\right.$ & 3607703 & 2152110 & 4192120 & 3567499 \\
\hline Área Fibrótica & $2794684 \pm$ & $5396028 \pm$ & $1653761 \pm$ & $2250839 \pm$ \\
$\left(\boldsymbol{\mu \mathbf { m } ^ { 2 } )}\right.$ & 4612384 & 4262357 & 2051646 & 4273158 \\
\hline
\end{tabular}




\begin{tabular}{|c|c|c|c|c|}
\hline $\begin{array}{l}\text { Área Total } \\
\qquad\left(\mu \mathrm{m}^{2}\right)\end{array}$ & $\begin{array}{c}18911318 \pm \\
12112969\end{array}$ & $\begin{array}{c}21319986 \pm \\
9084729\end{array}$ & $\begin{array}{c}16428756 \pm \\
10757476\end{array}$ & $\begin{array}{c}19397651 \pm \\
8984247\end{array}$ \\
\hline $\begin{array}{l}\text { Osso } \\
(\%)\end{array}$ & $\begin{array}{c}0.78 \pm \\
0.19\end{array}$ & $\begin{array}{c}0.59 \pm \\
0.12\end{array}$ & $\begin{array}{c}0.76 \pm \\
0.26\end{array}$ & $\begin{array}{c}0.73 \pm \\
0.22\end{array}$ \\
\hline $\begin{array}{c}\text { Cartilagem } \\
(\%)\end{array}$ & $\begin{array}{c}0.11 \pm \\
0.09\end{array}$ & $\begin{array}{c}0.19 \pm \\
0.05\end{array}$ & $\begin{array}{c}0.14 \pm \\
0.16\end{array}$ & $\begin{array}{c}0.18 \pm \\
0.15\end{array}$ \\
\hline $\begin{array}{c}\text { Fibrose } \\
(\%)\end{array}$ & $\begin{array}{c}0.09 \pm \\
0.11\end{array}$ & $\begin{array}{l}0.21 \pm \\
0.12 *\end{array}$ & $\begin{array}{c}0.09 \pm \\
0.11\end{array}$ & $\begin{array}{c}0.07 \pm \\
0.12\end{array}$ \\
\hline
\end{tabular}

* Significante diferença intergrupo (ANOVA one-way com pos-hoc Tukey, $\mathrm{p}<0.05$ ).

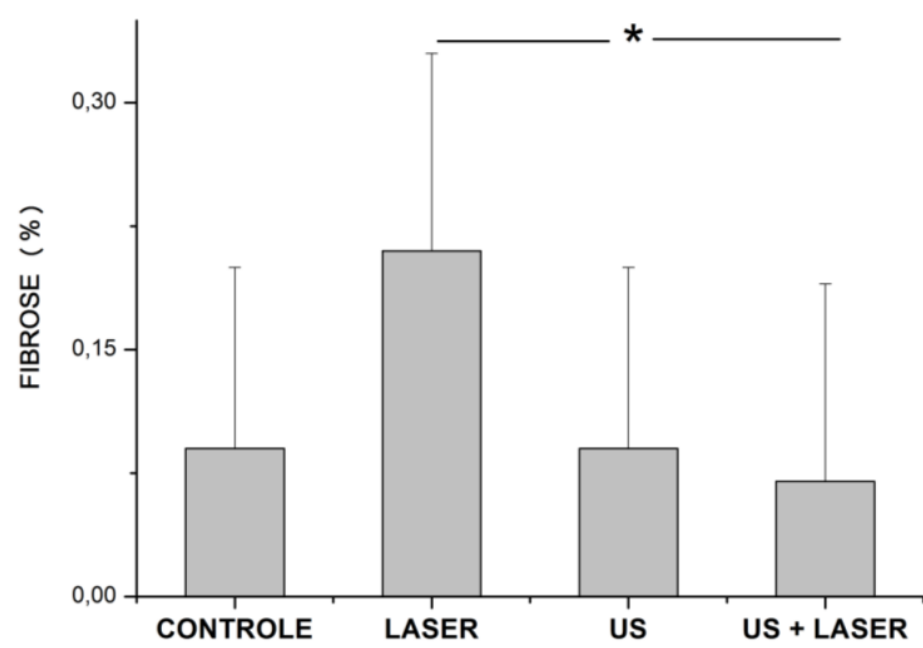

FIGURA 68 - Área fibrótica no calo ósseo obtida por histomorfometria. * Significante diferença intergrupo (ANOVA one-way com pos-hoc Tukey, $\mathrm{p}<0.05$ ). 


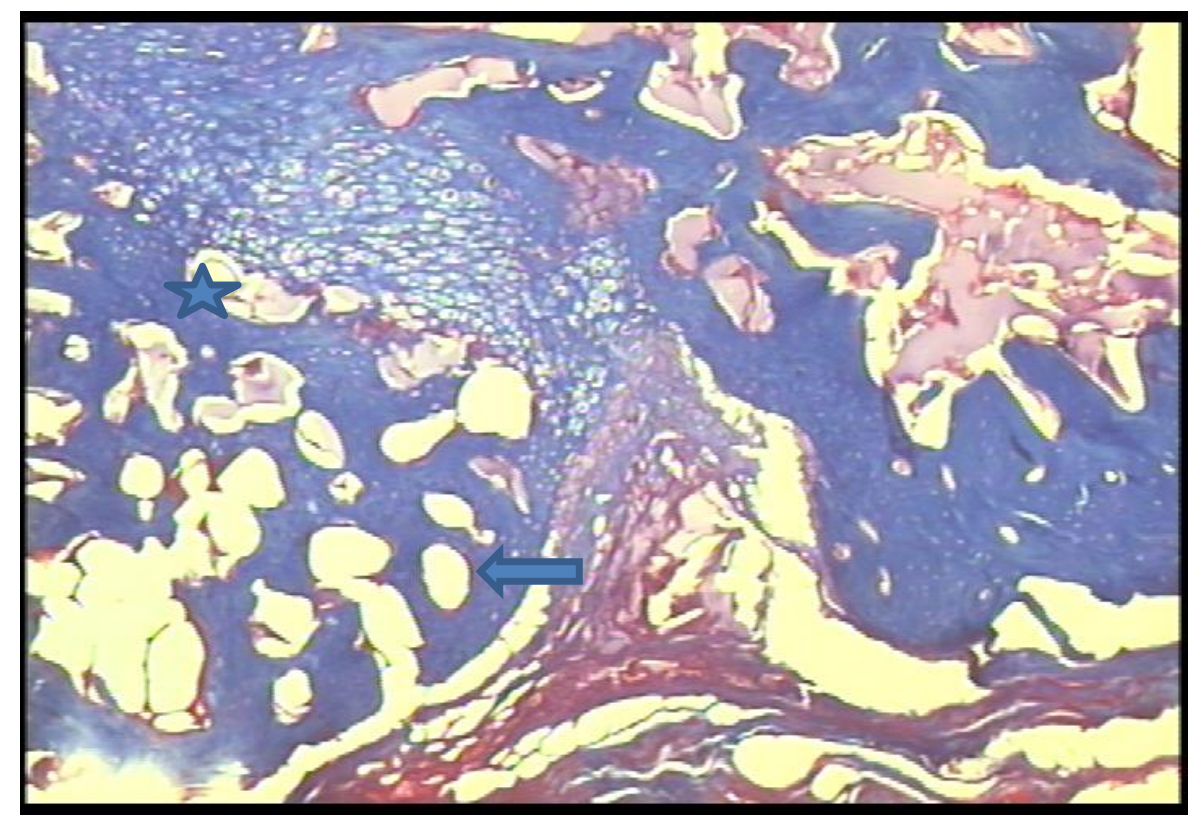

FIGURA 69 - Calo ósseo do grupo CONTROLE. Observar formação de tecido ósseo e cartilaginoso (*) e tecido fibroso (seta) na porção periosteal. Tricromico de Masson X40.

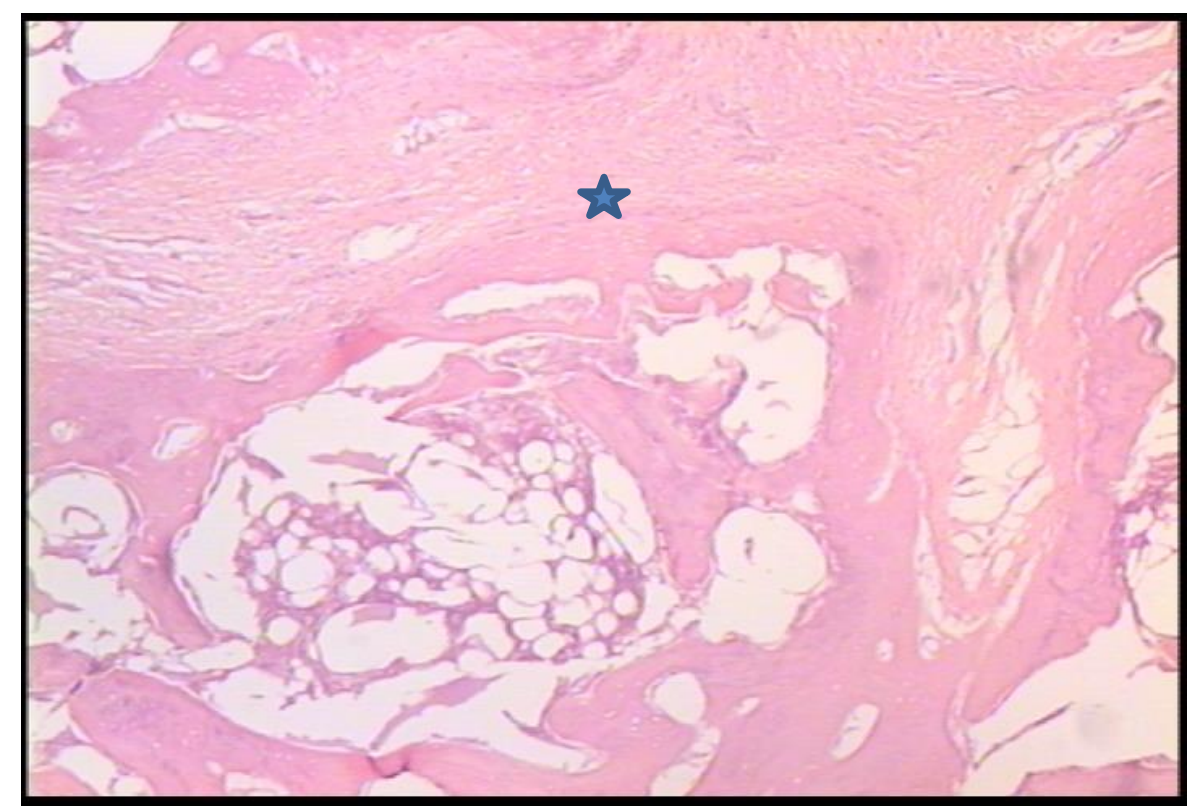

FIGURA 70 - Calo ósseo do grupo LASER. Notar tecido ósseo esponjoso e presença de tecido fibroso (*) que está unindo as duas porções do defeito ósseo. HEX40. 


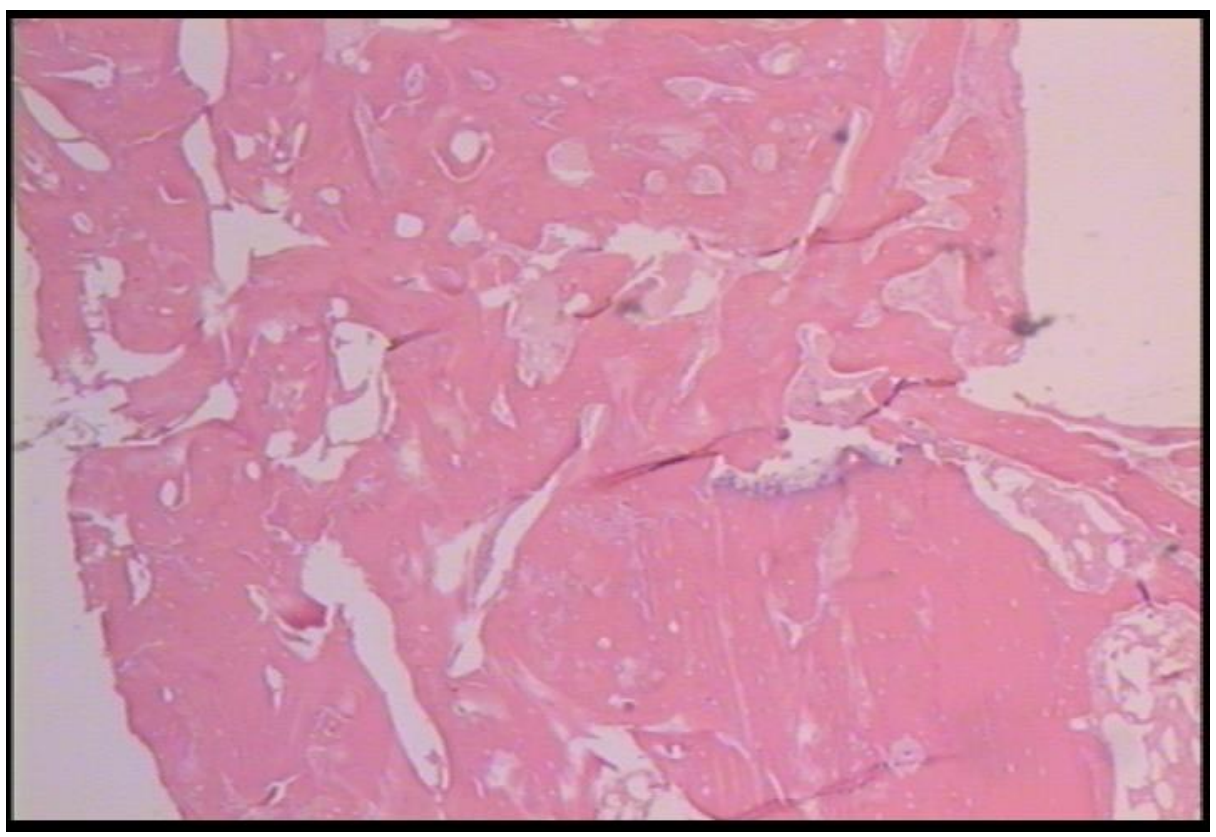

FIGURA 71 - Calo ósseo grupo US. Notar que defeito ósseo foi preenchido por tecido ósseo. HEX40.

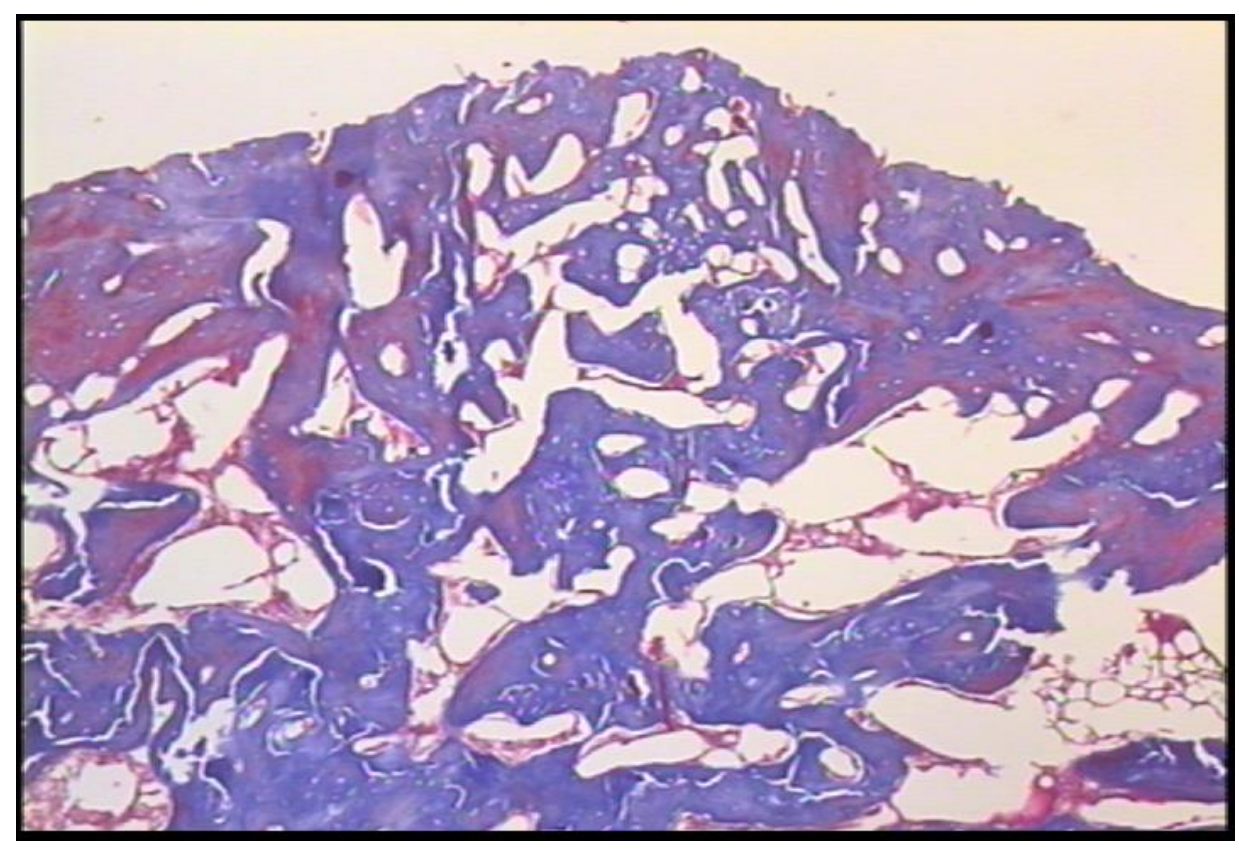

FIGURA 72 - Calo ósseo do grupo US+LASER. Notar defeito ósseo preenchido totalmente por tecido ósseo esponjoso. Tricromico X40. 


\section{DISCUSSÃO}

Este estudo é pioneiro na utlização da técnica da microtomografia por raio-x para avaliar o processo de reparo ósseo de uma fratura após tratamento com a aplicação sinérgica do LIPUS e Laser. Foi utilizado um modelo experimental de osteotomia completa em tíbias de ratos com retardo de consolidação causado pela colocação de um espaçador polimérico entre os fragmentos proximal e distal da fratura, conforme proposto por Miles et al. (2011). A maioria dos estudos descritos na literatura iniciou o tratamento com US ou Laser logo após a cirurgia para indução da fratura (LIRANI et al., 2004; RENNÓ et al, 2011; OLIVEIRA et al., 2011). Na investigação aqui descrita esse tratamento teve início em uma fase tardia, isto é, 5 semanas após a osteotomia total. A região óssea analisada (VOI) comprendeu 300 seções acima e abaixo da região central da mesma, totalizando 601 seções. A dimensão dessa região é de 5,96 mm, pois cada sessão tem uma espessura de $9.92 \mu \mathrm{m}$. O efeito do tratamento associado (LIPUS + Laser), avaliado por microtomografia por raio-x, foi o aumento da conectividade nessa região evidenciada pelo fator padrão trabecular (Tb.Pf), conectividade (Conn) e densidade de conectividade (D.Conn). A avaliação histológica indicou a presença de osso esponjoso, o que sugere qualidade tecidual do processo de reparo ósseo.

A técnica utilizada de estabilização da fratura por fio de Kirschner é caracterizada como não rigida e permite a ocorrência de micromovimentos e ação mecânica do peso corpóreo (MARSELL \& EINHORN, 2011). Essa ação resulta em efeito piezoelétrico devido às contrações musculares e a força de reação do solo (SHAPIRO, 2008; MEYER et al., 2005; CHAO e INOUE, 2003).

Agentes físicos, como o LIPUS (DUARTE, 1983; HECKMAN et al., 1994; KRISTIANSEN et al., 1997) e o Laser (LIRANI-GALVÃO, JORGETTI e da SILVA, 2006; OLIVEIRA et al. 2011) aceleram o processo de reparação óssea, conforme relatos da revisão bibliográfica.

O grupo Laser mostrou resultado significativo quanto à maior conectividade do tecido ósseo no volume de tecido ósseo investigado (volume de interesse) quando comparado ao grupo controle. $\mathrm{Na}$ análise histológica observa-se a presença de osso esponjoso, o que indica que o reparo foi mais acelerado e com melhor qualidade tecidual. Este grupo apresentou resultados significativos referentes à maior quantidade de tecido fibrótico quando comparado ao grupo US+Laser, o que caracteriza um processo de reparo mais rápido desse último. 
Os efeitos do laser vermelho $(633 \mathrm{~nm})$ sobre as trabéculas em defeito ósseo na tíbia foram investigados por Garavello-Freitas et al. (2003), que constataram o aumento da área trabecular e organização da matriz de colágeno após 7 dias de tratamento comparado ao grupo controle. Entretanto, após 14 dias foi constatado menor área trabecular. Os autores sugerem efeito biomodulatório do laser para remodelagem óssea.

Outro estudo (KO et al., 2013) investigou os efeitos do laser vermelho (660 nm) sobre a perda óssea trabecular em decorrência da ausência de carga corpórea de ratos com indução da denervação do ciático. Foi comprovado um aumento do número de trabéculas, maior conectividade e maior fração de volume ósseo comparado ao grupo controle não irradiado.

Embora estudos mostrem os benefícios do comprimento de onda vermelho, a profundidade de penetração do infravermelho é maior e, portanto, mais indicada para o tratamento ósseo ao considerar a composição corporal de animais e humanos. As interações da luz com o tecido biológico dependem da penetração, absorção e espalhamento da luz no tecido. A absorção e o espalhamento da luz no tecido biológico são dependentes do comprimento de onda e dos cromóforos no tecido. A hemoglobina e a melanina tem alta absorção nas bandas com comprimentos de onda menores que $600 \mathrm{~nm}$. Enquanto, a água começa a absorver significativamente em comprimentos de onda menores que $1.150 \mathrm{~nm}$. Assim, a janela óptica terapêutica é primeiramente limitada pela absorção, devido ao sangue em menores comprimentos de onda e à água em maiores comprimentos de onda (BAROLET, 2008). O infravermelho tem menor absorção e, então, maior penetração comparada à luz visível. A energia total por unidade de área que atinge a superfície do tecido como a dose entregue não é necessariamente a energia absorvida.

Segundo Pöntinen (2000) e Low e Reed (2001), a profundidade de penetração está relacionada com o comprimento de onda da radiação, sendo de 0,5 a $2 \mathrm{~mm}$ para a luz vermelha (635 - $670 \mathrm{~nm})$ e de 2 a $4 \mathrm{~mm}$ para a luz infravermelha (820 - $904 \mathrm{~nm})$. Ainda, de acordo com Pöntinen (2000) e Basford (1995) a fotobiomodulação pode ser conquistada a partir de uma dose de $4 \mathrm{~J} / \mathrm{cm}^{2}$ ao nível da pele, permitindo-se obter uma profundidade de 1,2 cm para a radiação com penetração de $2 \mathrm{~mm}$. Nas grandes articulações e músculos uma dose inicial de 100 a $300 \mathrm{~J} / \mathrm{cm}^{2}$ no tecido superficial é atenuada a $20 \mathrm{~J} / \mathrm{cm}^{2}$. Com uma efetiva dose a profundidade de 5 a $10 \mathrm{~cm}$ pode ser mantida (BASFORD, 1995; PÖNTINEN, 2000).

Vários estudos comprovam a eficácia do laser infravermelho sobre o reparo ósseo em diferentes protocolos realizados em animais. Queiroga et al. (2008) comparou os efeitos dos comprimentos de onda vermelho (laser $660 \mathrm{~nm}$ ) e infravermelho (laser $780 \mathrm{~nm}$ ) com $40 \mathrm{~mW}$ de potência e dose total de $200 \mathrm{~J} / \mathrm{cm}^{2}$ em quatro pontos sobre o tecido ósseo. Os resultados 
mostram que somente o infravermelho gerou efeitos de bioestimulação para acelerar o processo de reparação do defeito ósseo no fêmur de ratos. Segundo os autores este benefício ocorreu devido à maior penetrabilidade do infravermelho comparado à luz vermelha.

Outra pesquisa também compara os efeitos do laser vermelho e infravermelho sobre o processo de reparo ósseo em ratos submetidos à osteotomia do fêmur. Foram utilizados lasers com comprimento de onda 660 e $810 \mathrm{~nm}$, ambos com potência de $100 \mathrm{~mW}$ e dose de 140 $\mathrm{J} / \mathrm{cm}^{2}$. Os fêmures foram analisados por meio de densitometria óptica no período pós-lesão (7, 14 e 21 dias) e foi constatado um aumento significativo no grau de mineralização em ambos os grupos tratados com o laser depois de 7 dias. Entretanto, após 14 dias, somente o grupo tratado com laser infravermelho mostrou maior densidade óssea. Não foram observadas diferenças entre os grupos após 21 dias. Os resultados sugerem que o efeito positivo da fototerapia na reparação óssea é dependente do tempo e do comprimento de onda (BARBOSA et al., 2013).

Em outro estudo, Pretel, Lizarelli e Ramalho (2007) constatam que o laser infravermelho $\left(780 \mathrm{~nm}, 35 \mathrm{~mW}\right.$ e $\left.178 \mathrm{~J} / \mathrm{cm}^{2}\right)$ aplicado em único ponto, diretamente sobre a área do defeito ósseo da mandíbula de ratos, acelerou o processo de reparação do tecido ósseo. A hipótese citada pelos autores é que a fototerapia aumenta a produção de ATP e a atividade mitótica celular, que otimiza o processo de reparação óssea por acelerar a capacidade de cicatrização do tecido conectivo, além de propiciar a formação de novos vasos a partir dos pré-existentes.

O laser infravermelho também foi utilizado por Fávaro-Pípi et al. (2011) para acelerar o processo de reparação óssea em tíbias de ratos. Neste estudo, a irradiação com Laser (830 $\mathrm{nm}, 30 \mathrm{~mW}, 50 \mathrm{~J} / \mathrm{cm}^{2}$ ) começou $24 \mathrm{~h}$ após a cirurgia e foi realizada em 3, 6 e 12 sessões, com intervalo de 48 h. Os resultados histológicos das tíbias no período pós-lesão (7, 13 e 25 dias) revelaram intensa formação de osso novo, rodeado por tecido altamente vascularizado, apresentando atividade osteogênica, com deposição de osso primário no grupo tratado com laser nos estágios intermediário (13 dias) e final (25 dias) da reparação comparado ao grupo controle. Foi constatada maior expressão gênica referente à osteogênese, principalmente na fase final de recuperação.

Quando a luz interage com o tecido biológico ocorrem efeitos fotofísicos, fotoquímicos e fotobiológicos. Neste contexto, várias são as hipóteses sobre o mecanismo de ação da fototerapia (KARU, 1989; VLADIMIROV; OSIPOV; KLEBANOV, 2004): (i) a absorção da luz por fotoaceptores celulares localizados na mitocôntria, como o citocromo c e o NADH oxidase que acelera o transporte de elétrons na cadeia respiratória da mitocôndria e 
estimula a síntese de RNA e DNA; (ii) a absorção da luz por porfirinas e flavoproteínas que são responsáveis pela geração de oxigênio singleto e, portanto, estimulam a síntese de RNA e DNA; (iii) a atividade do citocromo c oxidase, sob condições fisiológicas, é também regulada pelo óxido nítrico $(\mathrm{ON})$ que pode reverter à inibição parcial do centro catalítico por meio do $\mathrm{ON}$, aumentando deste modo à concentração de oxigênio $\left(\mathrm{O}_{2}\right)$; (iv) a ativação de elétrons pela luz contribui para a produção de ânion superóxido e; (v) o aumento da permeabilidade da membrana celular facilita a mobilidade iônica para o cálcio $\left(\mathrm{Ca}^{++}\right)$, sódio $\left(\mathrm{Na}^{+}\right)$e potássio $\left(\mathrm{K}^{+}\right)$que aumenta a síntese de ATP, uma vez que a energia liberada pela hidrólise de ATP promoverá o correto funcionamento da bomba $\mathrm{Na}^{+} \mathrm{e} \mathrm{K}^{+}$.

O potencial de membrana reduzido e o estado redox celular alterado na presença de lesões teciduais e imunodepressão do sistema fisiológico faz com que a resposta ao tratamento com fototerapia aumente a taxa metabólica celular (DANHOF, 2000). Assim, diversos efeitos terapêuticos podem ocorrer incluindo mudanças nas expressões de genes, por exemplo, referente à biogênese mitocondrial e angiogênese que associadas à modulação de citocinas favorecem a ação anti-inflamatória e a regeneração tecidual, principalmente nos casos de fraturas ósseas (BOSSINI et al., 2012; MERLI et al., 2012).

A fototerapia aumenta o metabolismo osteogênico, com maior produção de osteoblastos decorrente do fator de crescimento semelhante à insulina do tipo 1 (IGF-1), fator de crescimento transformador beta (TGF- $\beta$ ), fator de crescimento fibroblástico (FGF) e fator de crescimento endotelial vascular (VEGF) (SHIMIZU et al., 2007; BOSSINI et al., 2012).

$\mathrm{O}$ radical livre óxido nítrico $(\mathrm{ON})$, que participa de vários eventos fisiológicos e fisiopatológicos, é uma importante substância vasodilatadora que atua, por exemplo, no aumento do fluxo sanguíneo, produção de energia e biogênese mitocondrial. Vários estudos foram realizados para investigar a relação da luz vermelha e infravermelha com o ON na função regulatória do metabolismo celular (KARU; PIATYBRAT; AFANASYEVA, 2004; KARU; PIATYBRAT; AFANASYEVA, 2005).

Um fator preponderante na reparação óssea é o aumento da vascularização que promove maior suplementação sanguínea e pode explicar a maior conectividade (Figura 64) do tecido ósseo observada no grupo Laser, pois melhora a suplementação de oxigênio para regeneração tecidual.

Trelles e Mayayo (1987) constatam em fratura de tíbias de ratos um aumento importante na vascularização e formação mais rápida de tecido ósseo com densa rede trabecular, modulação de osteócitos e rápida formação de calo ósseo, comparado ao grupo controle (laser He-Ne, 2.4 Joules, único ponto por 12 sessões de irradiação). 
A melhora da microarquitetura óssea propiciada pelo laser pode estar relacionada com modulação de marcadores de absorção e reabsorção óssea. No estudo de Merli et al. (2012) constata-se que os efeitos do laser $(660 \mathrm{~nm}, 100 \mathrm{~mW}$, aplicados em 3 pontos totalizando 240 $\mathrm{J} / \mathrm{cm}^{2}$ ) sobre o defeito ósseo em fêmur de ratos, modulou a expressão de sulfato de condroitina, ácido hialurônico, osteonectina e osteocalcina na matriz óssea. Isto resultou na formação acelerada da matriz óssea, com aumento da área de tecido ósseo neoformado, alterando a expressão de componentes da matriz extracelular. A osteocalcina é um marcador ósseo com relevante função na diferenciação dos osteoclastos, enquanto a osteonectina é uma glicoproteína secretada pelos osteoblastos durante a fase de formação óssea e está envolvida na fase inicial da mineralização.

Neste contexto, é importante ressaltar que no presente estudo o grupo Laser mostrou maior conectividade do tecido ósseo e presença de tecido esponjoso (fase final do reparo ósseo), entretanto, também apresentou tecido fibroso (fase inicial do reparo ósseo). Esta diferença na maturação óssea pode ser explicada pela distribuição da luz no tecido biológico, bem como pela presença do fio de Kirschner e do espaçador que podem ter influenciado a propagação e profundidade da penetração da luz. Ao iluminar um tecido a luz é transmitida e absorvida, além de ser refletida pela superfície (reflexão especular) e ser espalhada no interior do tecido (espalhamento difuso) (BAGNATO, 2008 b).

Os parâmetros do laser utilizados neste trabalho foram fundamentados pelo estudo de Rennó et al. (2006) e Bossini et al. (2012) que constatou estímulo osteogênico com laser de $100 \mathrm{~mW}$ e dose de $120 \mathrm{~J} / \mathrm{cm}^{2}$ aplicados em único ponto no fêmur de ratas ovarectomizadas. A ovarectomia é considerada um importante modelo de osteoporose.

Os parâmetros de irradiação entre estudos in vivo e in vitro são distintos. Nos estudos in vivo as potências e doses são maiores comparados ao estudo in vitro. Stein, Benayahu, Maltz e Oron (2005) investigaram o efeito da irradiação do laser na proliferação e diferenciação de células de osteoblastos humanos que foram cultivadas e irradiadas com laser vermelho $(632 \mathrm{~nm})$ de $10 \mathrm{~mW}$ de potência, durante 1,3 e $10 \mathrm{~s}$ e doses de $0.14,0.43$ e 1.43 $\mathrm{J} / \mathrm{cm}^{2}$. Os resultados mostraram que a fototerapia promove proliferação e maturação dos osteoblastos quando comparados às células que não foram irradiadas.

Estas diferenças nos parâmetros de estudos in vitro e in vivo podem ser explicados pela curva dose versus resposta biológica de Arndt-Schultz. De acordo com a lei de ArndtSchultz, se a energia aplicada não for suficiente, não haverá resposta, pois o limite mínimo não foi atingido. Se a energia aplicada for maior, a bioestimulação será alcançada. Entretanto, se a energia aplicada for excessiva o estímulo desaparece e pode ocorrer bioinibição. Esta lei 
prediz um efeito dose-dependente, ou seja, acredita-se que haja um valor de dose que acima do limiar ocasione fotobioestimulação, abaixo não ocorre resposta e um excesso ocasione fotobioinibição (PEPLOW; CHUNG; BAXTER, 2010).

A lei de Arndt-Schultz associada à distribuição de luz no tecido também explica as diferenças entre os estudos com cultura de célula, animais e humanos. O volume tecidual é maior nos humanos comparado aos ratos, devido às diferenças na composição corporal, o que pode diminuir a propagação da luz nos tecidos biológicos, diferentemente da irradiação de cultura de células. Neste contexto, os parâmetros de irradiação para bioestimulação óssea em humanos devem ser investigados na prática clínica.

Somente um estudo avaliou os efeitos da fototerapia (LEDs $850 \mathrm{~nm}, 100 \mathrm{~mW}$ e 108 $\mathrm{J} / \mathrm{cm}^{2}$ ) associado ao exercício físico na esteira ergométrica sobre a densidade mineral óssea em mulheres na pós-menopausa. Os resultados da densitometria óssea mostraram que no período de 1 ano houve atenuação da perda óssea em 50\% comparado ao grupo que só realizou exercícios (PAOLILLO et al., 2011b).

O osso ao receber um estímulo mecânico gera potenciais elétricos de dois tipos: o potencial de fluxo e o potencial piezoelétrico. A geração desses potenciais representa a conversão direta da energia mecânica em energia elétrica, o que favorece a osteogênese.

O efeito piezoelétrico está presente nas deformações dos tecidos ósseos. Nos locais de carga mecânica (deformação e tração) há deslocamento do fluxo de fluido intersticial que promove força de cisalhamento sobre a membrana celular de osteócitos (osteoblastos maduros), o qual resulta em aumento de nutrientes e de transporte metabólico dentro dos canalículos dos ossos. Os osteócitos enviam sinais bioquímicos, como as prostaglandinas, fatores de crescimento e citocinas, para células osteoprogenitoras e osteoblastos, que resultam em aumento da quantidade da matriz óssea (CARVALHO; CARVALHO; CLIQUET Jr., 2001).

Duarte (1983), na década de 70, iniciou estudos visando estimular a osteogênese através do LIPUS, demonstrando que estímulos mecânicos aceleram a consolidação óssea. Em um trabalho pioneiro, com animais, demonstrou que o LIPUS foi capaz de acelerar a consolidação em defeitos ósseos induzidos em coelhos (DUARTE, 1983). Vários são os resultados positivos do LIPUS sobre a osteogênese, conforme relatado na revisão de literatura do presente estudo. A partir das evidências em estudos animais e clínicos o Food and Drug Administration dos EUA aprovaram em 1994 o uso da tecnologia para o tratamento de fraturas recentes. A aprovação se extendeu para o uso em não-união e estudos comprovam o êxito da técnica em retardo de consolidação. 
Em estudo clínico com aplicação diária do LIPUS, após osteotomia na ulna, constatouse formação de calo ósseo e redução do tempo de união cortical e endosteal em 27 e 18\%, respectivamente, quando comparado ao grupo controle (URITA et al., 2013).

Em um estudo de caso de fratura no dedo anelar foram utilizados 2 fios de Kirschner para estabilização da fratura. A existência de uma não união-óssea há 5 meses resultou no tratamento diário com aplicação de 20 minutos de LIPUS. Depois de 4 semanas foi constatada a calcificação com presença de calo ósseo e aumento da amplitude articular (HUBER; PRANTL; GEHMERT, 2012).

No estudo de Fung et al. (2012) investigou-se diferentes intensidades de US (150 e 30 $\mathrm{mW} / \mathrm{cm}^{2}$ ) sobre a osteogênese em fratura femoral em ratos. Seus resultados mostram que a alta intensidade não promoveu melhores efeitos biológicos comparado a baixa intensidade. Segundo os autores, $30 \mathrm{~mW} / \mathrm{cm}^{2}$ acelerou o processo de reparação óssea, entretanto, ainda é necessário investigar o limiar de intensidade para promover efeitos biológicos efetivos.

No estudo de Chan et al. (2006), em modelo de alongamento ósseo na tíbia de coelhos após osteotomia, diferentes intensidades de US foram utilizadas com tempo de aplicação de 20 e 40 minutos. Foi constatado que 40 minutos de tratamento foi mais efetivo no aumento da regeneração óssea.

Em estudo in vitro, diferentes intensidades de US $\left(2,15\right.$ e $\left.30 \mathrm{~mW} / \mathrm{cm}^{2}\right)$ também foram investigadas e constatou-se que a intensidade de $30 \mathrm{~mW} / \mathrm{cm}^{2}$ é eficaz para acelerar o processo de reparação óssea com aumento da mineralização em 29 e $82 \%$ em 17 e 24 dias de tratamento, respectivamente (AGLE et al., 2011). Vale ressaltar que estudos in vitro diferem dos estudos in vivo, pois a interação da energia mecânica com o tecido biológico é mais complexa. Entretanto, os estudos in vitro são relevantes para melhor compreensão dos mecanismos envolvidos no processo de consolidação óssea. Neste contexto, em outro estudo in vitro, foi constatado que o US regula a proliferação e diferenciação dos osteoblastos por meio de osteócitos com aumento da secreção de prostoglandina E2 (PGE2) e de óxido nítrico para formação óssea, o que pode explicar a aceleração na recuperação de fraturas (LI et al., 2012). No estudo de Kumagai et al. (2012), o LIPUS foi aplicado em fratura femoral de ratos e mostrou o aumento da formação óssea devido à presença de células progenitoras osteogênicas advindas da circulação sistêmica.

Em estudo experimental com fratura na tíbia de coelhos, com espaçamento de $2 \mathrm{~mm}$ e uso de fixador externo, foi constatado através de microtomografia que a aplicação do US acelerou o processo de reparação óssea no plano de aplicação do US, mas também nos outros dois planos com aumento da formação do canal medular e do córtex (TOBITA et al., 2012). 
Recentes estudos clínicos (HEMERY et al., 2011; ROSSIGNOL et al., 2012) mostram a importância do LIPUS na reparação óssea de casos com atraso de consolidação de fraturas e não-união óssea. As vantagens do uso do US são a redução do tempo de consolidação óssea em fraturas recentes, o baixo custo, o procedimento é não invasivo e domiciliar.

Um estudo (AL-HABIB et al., 2011) avaliou os efeitos do US e do Laser associados sobre a fratura parcial do fêmur. Entretanto, os parâmetros descritos de US e Laser não são comumente utilizados nas pesquisas com tecido ósseo. O US utilizado apresentava $1 \mathrm{MHz}$ de frequência e $50 \mathrm{~mW} / \mathrm{cm}^{2}$ de intensidade, aplicados durante 2 minutos, perpendicularmente ao Laser Neodímio:Ítrio-Aluminio-Granada (Nd:YAG) infravermelho (1064 nm) com potência de $135 \mathrm{~mW}$ e 16 joules $/ \mathrm{cm}^{2}$ de energia, aplicados em único ponto. O tratamento não foi diário. Este protocolo foi escolhido pelos autores para que o US aumentasse a penetração do laser (EDEE \& OGULU, 1995). Os resultados mostraram que o laser acelerou o processo de reparação óssea comparado ao grupo controle e quando o US foi adicionado, o periósteo apresentou-se mais desenvolvido quando comparado aos outros grupos.

Entretanto, fatores como sexo, idade, sítio da fratura (por exemplo, fêmur, tíbia, antebraço, úmero e falanges), tabagismo e a quantidade de cirurgias realizadas anteriormente ou o tipo de osteossíntese, interferem na consolidação (LERNER; STEIN; SOUDRY, 2004). Assim, sugere-se a associação de técnicas como enxertos ósseos, biomateriais (como a hidroxiapatita), implantes autólogos (como o concentrado de medula óssea, a proteína morfogenética óssea e o plasma rico em plaquetas) (MASSON \& DUNNIL, 2008; WATANABE et al., 2013;) com a aplicação de agentes físicos como o LIPUS e o Laser (KOCYIGIT et al., 2012), desde que a fixação da fratura esteja estável para favorecer o sucesso do tratamento.

Estudos fotoacústicos de diagnóstico por imagens utilizam a associação de US e Laser pulsado para que o US aumente a penetração tecidual da luz para maior resolução espacial (WANG et al., 2012; KONG et al. 2009). Entretanto, estudos fotoacústicos terapêuticos com phantom para US e Laser devem ser realizados para investigar os efeitos desta associação de energias sobre a penetração tecidual.

A maioria dos estudos com tecido ósseo comparam os efeitos do Laser com o LIPUS aplicados individualmente, mas não em associação. Lirani, Jorgetti e da Silva (2006) constataram que o LIPUS e o Laser promoveram mudanças na reparação óssea, mas em diferentes fases deste processo. O LIPUS aumentou a reparação promovendo a reabsorção óssea na área fraturada, enquanto o Laser acelerou o processo por meio da formação óssea e do aumento da resistência mecânica máxima quando comparado aos grupos controle e LIPUS. 
Concluiu-se que tanto o Laser quanto o LIPUS foram capazes de aumentar a área de tecido ósseo neoformado, acelerando o processo de reparo ósseo após a indução do defeito em tíbias de ratos. Outro estudo comparativo entre US e laser foi realizado por Oliveira et al. (2011), que também constatou que as duas tecnologias aceleram o processo de reparo ósseo em defeito de tíbia de ratos com aumento da área de tecido ósseo neoformado. Resultados similares de aceleração da reparação óssea foram obtidos por Kocyigit et al. (2012) no tratamento da distração osteogênica da mandíbula associada ao tratamento de Laser ou US em coelhos.

Resultados divergentes também foram observados. No estudo de Fávaro-Pípi et al. (2010) o laser foi mais efetivo comparado ao LIPUS em fratura de tíbia de rato. Os autores constataram intensa neoformação óssea ao redor do tecido conjuntivo altamente vascularizado demonstrando atividade osteogênica e deposição de osso primário no grupo irradiado por Laser no período de 13 e 25 dias pós-lesão.

$\mathrm{Na}$ presente investigação a ausência de resultado significativo no reparo ósseo, comparando-se os grupos tratados com o grupo controle, pode estar relacionada ao tratamento tardio e ao uso do espaçador polimérico não absorvível. Importante ressaltar que as imagens histológicas mostram a presença predominante de tecido ósseo no reparo das fraturas do grupo LIPUS + Laser, diferentemente do grupo controle que apresenta tecido cartilaginoso e fibroso. O grupo LIPUS mostrou redução significativa do padrão fator trabecular comparado ao grupo controle, o que indica maior conectividade do tecido na região da fratura.

Diante dos benefícios terapêuticos das duas tecnologias, comprovado em um número significativo de estudos experimentais e clínicos, sugere-se que novos protocolos sejam realizados associando-se LIPUS e Laser para otimizar o processo de reparação de lesões. A LIPUS é uma realidade clínica mundial com aprovação do FDA cujo uso em diferentes países permite estudo de metanálise. O Laser para reparo ósseo ainda não está presente nas revisões sobre técnicas de tratamento de fratura (MARSELL \& EINHORN, 2010) e o seu uso na clínica ainda é um desafio.

A técnica de microtomografia por raio-x tem um enorme potencial investigativo permitindo análises qualitativas e quantitativas e reconstrução $2 \mathrm{D}$ e 3D. Os estudos de Morgan et al. (2009) e Salmon et al. (2012) demonstram que a avaliação do reparo ósseo em fraturas pode ser realizada com maior ou menor resolução microtomográfica, respectivamente. No primeiro estudo é importante ressaltar que um número maior de níveis de cinza foi utilizado. Salmon utilizou o mesmo número de níveis de cinza da presente 
investigação e relatou que a separação do calo ósseo teria sido possível se uma resolução maior que $9.92 \mu \mathrm{m}$ fosse utilizada.

O modelo experimental de fratura para induzir um retardo de consolidação através de um espaçador polimérico é novo na literatura. Miles et al. (2011) usaram o polímero poliéterterketone (PPEK) mas não relataram se esse material é absorvível. Na presente investigação utilizou-se o polímero polietileno que não foi absorvido pelo organismo dos animais (Figura 64). A não reabsorção do espaçador pode ter sido um grande obstáculo ao reparo ósseo em todos os grupos experimentais e pode explicar a inexistência de avanço no reparo ósseo entre os grupos.

Sugere-se investigar a otimização dos parâmetros de níveis de cinza e resolução microtomográfica que permitam separar o tecido neoformado de reparo (calo) do tecido normal em modelos experimentais de fratura animal. $\mathrm{O}$ uso de elementos finitos para se avaliar a resistência mecânica do reparo de uma fratura, utilizando-se as imagens reconstruídas do reparo, também é relevante na avaliação de técnicas de tratamento de fraturas e deve ser um tema de futuras investigações. 


\section{CONCLUSÃO}

A avaliação por microtomografia por raio-x do reparo ósseo tem um grande potencial para a avaliação de técnicas de tratamento de fraturas como, por exemplo, a que utiliza os efeitos terapêuticos da associação sinérgica do ultrassom de baixa intensidade (LIPUS) e laser infravermelho de baixa potência (LLLT).

Os benefícios desse sinergismo foram parcialmente comprovados nessa investigação, pelo aumento da conectividade evidenciada pelo fator padrão trabecular (Tb.Pf), conectividade (Conn) e densidade de conectividade (D.Conn) e a presença de osso esponjoso que indica qualidade tecidual do processo de reparo.

A resolução e/ou os níveis de cinza utilizados na reconstrução 2D não permitiram a separação do tecido neoformado presente no reparo ósseo.

O espaçador polimérico utilizado no modelo cirúrgico pode ter sido um obstáculo ao reparo ósseo, pois não foi absorvido pelo organismo animal, conforme observado nos cortes longitudinais das tíbias após o sacrifício dos animais.

O modelo experimental de fratura em tíbia de ratos desse estudo é de fácil implementação, mas o uso do espaçador polimérico, capaz de induzir reparos com retardo de consolidação ou não-união, deve ser melhor investigado sugerindo-se que o material do espaçador seja reabsorvível. 


\section{REFERÊNCIAS ${ }^{1}$}

AGLE, S.R. et al. Osteogenic differentiation of rat bone marrow stromal cells by various intensities of low-intensity pulsed ultrasound. Ultrasonics. 51, 281-288, 2011.

AL-HABIB, M.F.; SALMAN, M.O.; FALEH, F.W.; AL-ANI, I.M. Histological Observation Related to the Use of Laser and Ultrasound on Bone Fracture Healing. The International Medical Journal Malaysia. 10,2: 29-35, 2011.

ALLEN, R.J. Physical Agents Used in the Management of Chronic Pain by Physical Therapists. Phys Med Rehabil Clin N Am. 17, 315-345, 2006.

ASSIS, A.K.T. Óptica - Issac Newton. Ed. Edusp (Ed. da Universidade de São Paulo), 2002.

BAGNATO, V.S. Laser e suas aplicações em Ciência e Tecnologia. Ed. Livraria da Física. 2008a. pp. 1-87.

BAGNATO, V.S. Novas Técnicas Ópticas. Ed. Livraria da Física. 2008b. pp. 1-239.

BAILEY, M.R.; KHOKHLOVA,V.A.; SAPOZHNIKOV, O.A.; KARGL, S.G.; CRUM, L.A. Physical Mechanisms of the Therapeutic Effect of Ultrasound. Acoustical Physics. 49(4), 369-388, 2003.

BARBOSA, D. et al. Effects of low-level laser therapy (LLLT) on bone repair in rats: optical densitometry analysis. Lasers in Medical Science. 28:2, 651-656, 2013.

BAROLET, D. Light-Emitting Diodes (LEDs) in Dermatology. Semin Cutan Med Surg, 27: 227-238, 2008.

BARUSHKA, O.; YAAKOBI, T.; ORON, U. Effect of low-energy laser (He-Ne) irradiation on the process of bone repair in the rat tibia. Bone. 16:47-55, 1995.

BASFORD, J.R. Low Intensity Laser Therapy: Still Not an Established Clinical Tool. Lasers in Surgery and Medicine.16, 331-342, 1995.

BASSETT, C.A.L. Biophysical principles affecting bone structure. In: Bourne GH, editor. Biochemistry and physiology of bone, 2nd edition, New York, Academic Press, p. 341-76, 1971.

b.cube. disponível em $<$ http://www.bcube.ch/index.php?option=com_content $\&$ view=article\&id=22\&Itemid=20>. Acesso em: $7 / 10 / 13$.

BEARD, P. Biomedical photoacoustic imaging. Interface Focus. 1, 602-631, 2011. doi:10.1098/rsfs.2011.0028.

BLAYA, D.S. et al. Histologic study of the effect of laser therapy on bone repair. Contemp Dent Pract. 9:41-48, 2008. 
Bone mineral density (BMD) and tissue mineral density (TMD) calibration measurement by micro-CT using Bruker-MicroCT and CT-Analyzer, Method Note, 2012.

BOSKeY, A.; COLEMAN, R. Aging and Bone. J Dent Res, 89:1333-1348, 2010.

BOSSINI, P.S; RENNÓ, A.C.M.; RIBEIRO, D.A.; FANGEL, R.; RIBEIRO, A.C.; LAHOZ, M.A.; PARIZOTTO, N.A. Low level laser therapy $(830 \mathrm{~nm})$ improves bone repair in osteoporotic rats: similar outcomes at two different dosages. Experimental Gerontology. 47, 136-142, 2012.

BOUXSEIN, M.L.et al. Guidelines for Assessment of Bone Microstructure in Rodents Using Micro-Computed Tomography. Journal of Bone and Mineral Research, 25, 7: 14681486, 2010.

BUSSE, J.W. et al. The Effect of Low-Intensity Pulsed Ultrasound Therapy on Time to Fracture Healing: a Meta-Analysis. CMAJ. 166:437-41, 2002.

CARANO, R.A.; FILVAROFF, E.H. Angiogenesis and bone repair, Drug Discovery Today 8(21):980-9, 2003.

CARBONARE, L. D. et al. Bone microarchitecture evaluated by histomorphometry. Bone, 36, 2005.

CARDOZO, R.T. et al. Tratamento das fraturas diafisárias da tíbia com fixador externo comparado com a haste intramedular bloqueada. Rev Bras Ortop. 48, 2:137-144, 2013.

CARVAlHO, D.C.L.; CARVAlHO, M.M.; CliQUET, Jr. A Disuse Osteoporosis: Its relationship to Spine Cord Injuried Patient Rehabilitation. Acta Ortop. Bras. 9, 3: 34-43. 2001.

CASTANO, A.P et al. Low-Level Laser Therapy for Zymosan-Induced Arthritis in Rats: Importance of Illumination Time. Lasers in Surgery and Medicine. 39, 543-550, 2007.

CEYLAN, Y.; HIZMETLE, S.; SILIG, Y. The Effects of Infrared Laser and Medical Treatments on Pain and Serotonin Degradation Products in Patients with Myofascial Pain Syndrome: A Controlled Trial. Rheumatol. Int. 24: 260-263, 2004.

CHAN, C.W. et al. Low Intensity Pulsed Ultrasound Accelerated Bone Remodeling During Consolidation Stage of Distraction Osteogenesis. J Orthop Res. 24(2): 263-70, 2006.

CHAN, C.W. et al. Dose-Dependent Effect of Low-Intensity Pulsed Ultrasound on Callus Formation during Rapid Distraction Osteogenesis. J Orthop Res. 24:2072-9, 2006b.

CHAO, E.Y.S.; INOUE, N. Biophysical stimulation of bone fracture repair, regeneration and remodeling. European Cells and Materials. 6: 72-85, 2003.

CHAPPARD, D. et al. Fractal dimension of trabecular bone: comparison of three histomorphometric computed techniques for measuring the architectural twodimensional complexity. J. Pathol. 195: 515-521, 2001. 
CHAPPARD, D.; ALEXANDRE, C.; RIFFAT, G. Spatial distribution of trabeculae in iliac bone from 145 osteoporotic females. Acta Anatomica, 132: 137-142, 1988.

CHAUHAN, A.; SARIN, P. Low Level Laser Therapy in Treatment of Stress Fractures Tibia: A Prospective Randomized Trial. MJAFI, 62: 27-29, 2006.

CHEN Y., ALMAN B.A. Wnt pathway, an essential role in bone regeneration. Journal of Cellular Biochemistry, 106 (3):353-62, 2009

CHIVUKULA, V.S.; SHUR, M.S.; ČIPLYS, D. Recent advances in application of acoustic, acousto-optic and photoacoustic methods in biology and medicine. Phys. Stat. Sol.; 204,10: 3209-3236. DOI 10.1002/pssa.200723313. 2007.

CHOW, R.T; DAVID, M.A.; ARMATI, P.J. 830 nm Laser Irradiation Induces Varicosity Formation, Reduces Mitochondrial Membrane Potential and Blocks Fast Axonal Flow in Small and Medium Diameter Rat Dorsal Root Ganglion Neurons: Implications for the Analgesic Effects of 830 nm Laser. Journal of the Peripheral Nervous System 12, 28-39, 2007.

CLAES, L.; WILLIE, B. The Enhancement of Bone Regeneration by Ultrasound. Prog Biophys Mol Biol. 93(1-3): 384-98, 2007.

CLARKE, B. Normal Bone Anatomy and Physiology. Clinical journal of the American Society of Nephrology. 3 (3): S131-S139, 2008.

COMPSTON, J.E.; MELLISH, R.W.E.; GARRAHAN, N.J. Age-related changes in iliac crest trabecular micro-anatomic bone in man, Bone 8: 289-312, 1987.

CORAZZA, A.V. Fotobiomodulação comparativa entre o laser e LED de baixa intensidade na angiogênese de feridas cutâneas de ratos. Dissertação de mestrado. Programa de Pós-Graduação Interunidades em Bioengenharia da Universidade de São Paulo (USP). 2005. 89p.

COWIN, S.C. On Mechanosensation in Bone under Microgravity. Bone. 22: 119S-125S, 1998.

CROCI, A.T. et al. Efeito do Concentrado de Plasma em Falhas Ósseas Provocadas em Fêmures de Camundongos como Estimulação de Formação Óssea. Estudo experimental. Acta Ortop Bras. 11, 4: 203-39, 2003.

CROUCHER P.I., GARRAHAN N.J., COMPSTON J.E. Assessment of cancellous bone structure: comparison of strut analysis, trabecular bone pattern factor, and marrow space star volume, Jorunal of Bone and Mineral Research, 11: 955-961, 1996.

DANHOF, G. Biological Effects of the Laser Beam. In Simunovic Z., Lasers in Medicine and Dentistry, 127-152. Zagrzeb, 2000.

DATTA, H. K. et al. The cell biology of bone metabolism. J Clin Pathol, 61: 577-587, 2008. doi: 10.1136/jcp.2007.048868.

1 De acordo com as normas da ABNT 6023 
DEMPSTER, D.W. et al. Temporal changes in cancellous bone estructure of rats after ovarectomy. Bone. 16, 157-161, 1995.

DOBLARÉ, M.; GARCÍA, J.M.; GÓMEZ, M.J. Modelling bone tissue fracture and healing: a review. Review Article Engineering Fracture Mechanics.71 (13-14): 1809-1840, 2004.

DUARTE, L.R. The stimulation of bone growth by ultrasound. Archives of Orthopaedic and Traumatic Surgery. 101; 153-159; 1983.

DUNLOP, J.W.C. et al. New Suggestions for the Mechanical Control of Bone Remodeling. Calcified Tissue International. 85 (1); 45-54, 2009.

DYSON, N.A. Radiation Physics with Applications in Medicine and Biology. Vol. 2. Chichester: Ellis Horwood, 1993.

EDEE, M.K.A.; OGULU, A. Simulation of Ultrasound Interaction with tissue, an edition from International Centre for Theoretical Physics. Trieste, Italy, 1995.

EINHORN, T.A. Enhancement of Fracture-Healing. J Bone Joint Surg Am.77: 940-56, 1995.

EINHORN T.A. Production of a Standard Closed Fracture in Laboratory Animal Bone. Journal of Orthopaedic Research, 2; 97-101, 1984.

EINHORN, T.A. The Cell and Molecular Biology of Fracture Healing. Clin Orthop. 355S: S7-S21, 1998.

EINHORN T.A. The Science of Fracture Healing. Journal of Orthopaedic Trauma. 19,10: s4-s6, 2005.

EL-MOWAFI, H; MOHSEN, M. The Effect of Low-Intensity Pulsed Ultrasound on Callus Maturation in Tibial Distraction Osteogenesis. Int Orthop. 29:121-4, 2005.

ENCYCLOPEDIA

$<$ http://encyclopedia2.thefreedictionary.com/Convex+body $>$. Acesso em: 7/10/13.

FÁVARO-PÍPI E. et al. Comparative Study of the Effects of Low-Intensity Pulsed Ultrasound and Low-Level Laser Therapy on Bone Defects in Tibias of Rats. Lasers Med Sci 25:727-732, 2010.

FÁVARO-PÍPI, E. et al. Low-Level Laser Therapy Induces Differential Expression of Osteogenic Genes During Bone Repair in Rats. Photomedicine and Laser Surgery, 29, 5, 311-317, 2011.

FILLIPIN, L.I. et al. Low-Level Laser Therapy (LLLT) Prevents Oxidative Stress and Reduces Fibrosis in Rat Traumatized Achilles Tendon. Lasers in Surgery and Medicine. 37, 293-300, 2005. 
Referências $\mid 118$

Fractals, Fractal dimension, Fractal in Nature disponível em <http://fractalstudy.blogspot.com.br/>. Acesso em: 8/10/13.

FELDKAMP, L.A.; DAVIS, L.C.; KRESS, J.W. Practical Cone-Beam Algorithm. Journal of Accoustical Society. 1, 6: 612-619, 1984.

FELDKAMP L.A., GOLDSTEIN S.A., PARFITT M., JESION G., KLEEREKOPER M. The direct examination of there-dimensional bone architecture in vitro by computed tomography, Journal of Bone and Mineral Research. 4, 1, 1989.

FUNG, C.H. et al. Effects of Different Therapeutic Ultrasound Intensities on Fracture Healing in Rats. Ultrasound in Med. \& Biol. 38 (5), 745-752, 2012.

GAMA, L.O. Artrodese Atlanto-Axial em Cães Tratada por Ultra-Som de Baixa Intensidade, Dissertação de Mestrado apresentada no Programa de Pós-Graduação Interunidades Bioengenharia, 2002.

GARAVELLO-FREITAS, I. et al. Low-power laser irradiation improves istomorphometrical parameters and bone matrix organization during tibia wound healing in rats. Photochem Photobiol. 70:81-9, 2003.

GARTNER, L.P.; HIATT, J.L. Tratado de Histologia. Rio de Janeiro: Guanabara Koogan, Cap. 7, 2003.

GENANT, H.K., GUGLIEMI, G., JERGAS, M. editors. Beyond Bone Densitometry: Assessment of Bone Architecture by X-Ray In: Bone Densitometry and Osteoporosis, 1998.

GERTENFELD, L.C.; CULlinANE, D.M.; BARNES, G.L. Fracture Healing as a PostNatal Developmental Process: Molecular, Spatial, and Temporal Aspects of its Regulation. Journal of Cell Biochemistry. 88(5): 873-874, 2003.

GIANNINI, S. et al. Low-Intensity Pulsed Ultrasound in the Treatment of Traumatic Hand Fracture in an Elite Athlete. Am J Phys Med Rehabil. 83(12): 921-5, 2004.

GOLD, S.M.; WASSERMAN, R. Preliminary Results of Tibial Bone Transports with Pulsed Low Intensity Ultrasound (Exogen). J Orthop Trauma. 19, 1: 10-6, 2005.

GREEN, E.; LUBAHAN, J.D.; EVAN, J. Risk Factors, Treatment, and Outcomes Associated with Nonunion of the Midshaft Humerus Fracture. Journal of Surgery Orthopaedic Advanced. 14(2):64-72, 2005.

GROSS, T.S.; RUBIN, C.T. Uniformity of Resorptive Bone Loss Induced by Disuse. Journal of Orthopaedic Research.13, 5: 708-714, 1995.

HAAR, D. Therapeutic Ultrasound. European Journal of Ultrasound, 9:3-9, 1999.

HAGIWARA, S.; IWASAKA, H.; OKUDA, K.; NOGUCHI, T. GaAlAs (830 nm) LowLevel Laser Enhances Peripheral Endogenous Opioid Analgesia in Rats. Lasers in Surgery and Medicine. 39, 797-802, 2007. 
HAIRE, T.J.; HODGSKINSON. R.; GANNEY, P.S.; LANGTON, C.M. A Comparison of Porosity, Fabric and Fractal Dimension as Predictors of the Young's Modulus of Equine Cancellous Bone. Medical Engineering \& Physics 20: 588-593, 1998.

HAHN, M. et al. Trabecular Bone Pattern Factor-A New Parameter for Simple Quantification of Bone Microarchitecture. Bone. 13, 4:327-320, 1992.

HANNOUCHE, D. et al. Current Trends in the Enhancement of Fracture Healing. J Bone Joint Surg Br. 83(2): 157-64, 2001.

HECKMAN, J.D. et al. Acceleration of tibial fracture-healing by non-invasive, lowintensity pulsed ultrasound. Journal of Bone and Joint Surgery. 76, 26-34, 1994.

HEMERY et al. Low-intensity pulsed ultrasound for non-union treatment: A 14-case series evaluation. Orthopaedics \& Traumatology: Surgery \& Research 97, 51-57, 2011.

HEWES, G.W. Primate Communication and the Gestural Origin of Language. Current Anthropology. 14, 5-24, 1973.

HODE, L. The importance of the Coherency. Photomedicine and Laser Surgery, Larchmont, 23, 4: 431-434, 2009.

HUBER M.; PRANTL L.; GEHMERT S. Successful treatment of nonunion in severe finger injury with low-intensity pulsed ultrasound (LIPUS): a case report. Journal of Medical Case Reports, 6:209, 2012. Disponível em http://www.jmedicalcasereports.com/content/6/1/209.

JAKSE, N. et al. LLLT on bone regeneration and osseointegration of dental implants. Clin. Oral Impl. Res. 18: 517-524, 2007.

JUNQUEIRA, L.C.; CARNEIRO, J. Histologia básica. 10. ed. Rio de Janeiro: Guanabara, 2008 .

KALFAS, I.H. Principles of Bone Healing. Neurosurg Focus, 10:1-8, 2001.

KARU, T.I. Photobiology of Low-Power Laser Therapy. Harwood Academic Publishers. Chur, Switzerland, p. 1-187, 1989.

KARU, T.I.; PIATYBRAT, L.V.; AFANASYEVA, N.I. A Novel Mitochondrial Signaling Pathway Activated by Visible-to-near Infrared Radiation. Photochemistry and Photobiology. 80, 366-372, 2004.

KARU, T.I.; PIATYBRAT, L.V.; AFANASYEVA, N.I. Cellular Effects of Low Power Laser Therapy can be Mediated by Nitric Oxide. Lasers in Surgery and Medicine. 36, 307$314,2005$.

KEEN, R. Osteoporosis: strategies for prevention and management. Best Practice \& Research Clinical Rheumatology. 21, 1: 109-122, 2007. 
KOEKE, P.U.; PARIZOTTO, N.A.; CARRINHO, P.M.; SALATE, A.C.B. Comparative study of the efficacy of the topical application of hydrocortisone, therapeutic ultrasound and phonophoresis on the tissue repair process in rat tendons. Ultrasound in Med. \& Biol. 31(3):345-350. DOI:10.1016/j.ultrasmedbio.2004.12.005, 2005.

KO, C.Y. et al. The Effects of Minimally Invasive Laser Needle System on Suppression of Trabecular Bone Loss Induced By Skeletal Unloading. Lasers Med Sci 28:1495-1502, 2013.

KOCYIGIT, I.D. et al. A Comparison of the Low-Level Laser Versus Low Intensity Pulsed Ultrasound on New Bone Formed through Distraction Osteogenesis. Photomed Laser Surg. 30(8):438-43, 2012.

KONG, Y.C. et al. High-Resolution Photoacoustic Imaging with Focused Laser and Ultrasonic Beams. Applied Physics Letters. 94, 0339021-3, 2009.

KRISTIANSEN, T.K. et al. Accelerated healing of distal radial fractures with the use of specific low-intensity ultrasound. The Journal Bone and Joint Surgery Am. 79, 7: 961-973, 1997.

KUMAGAI et al. Low-Intensity Pulsed Ultrasound Accelerates Fracture Healing by Stimulation of Recruitment of Both Local and Circulating Osteogenic Progenitors. J Orthop Res 30:1516-1521, 2012.

KUMAR, V. et al. Robbins Basic Pathology. 8th ed. New York: Saunders Elsevier, 2007.

LAVIGNE M; MASSE V; GIORARD J, ROY AG; VENDITTOLI PA. Return to sport after hip resurfacing or total hip arthroplasty:a randomized study. Rev Chir Orthop Reparatrice Appar Mot. 94:361-7; 2008.

LAVON, I.; KOST, J. Ultrasound and transdermal drug delivery. Drug Discovery Today. 915:670-676, 2004.

LERNER A.; STEIN H.; SOUDRY M. Compound high-energy limb fractures with delayed union: our experience with adjuvant ultrasound stimulation (exogen). Ultrasonics 42, 915-917, 2004.

LI, L. et al. Low-Intensity Pulsed Ultrasound Regulates Proliferation and Differentiation of Osteoblasts through Osteocytes. Biochemical and Biophysical Research Communications 418, 296-300, 2012.

LIND, M.; BUNGER, C. Factors Stimulating Bone Formation. Eur. Spine J. 10: S102-9, 2001.

LIRANI, A.P.R. Estudo Comparativo dos Efeitos do Ultra-Som e do Laser de Baixa Intensidade no Reparo Ósseo de Tíbia de Rato. Dissertação de Mestrado - Escola de Engenharia de São Carlos/Faculdade de Medicina de Ribeirão Preto/Instituto de Química de São Carlos, Universidade de São Paulo, São Carlos, 2004. 
LIRANI-GAlVÃO, A.P.; JORGETTI, V.; da SILVA, O.L. Comparative Study of How Low-Level Laser Therapy and Low-Intensity Pulsed Ultrasound Affect Bone Repair in Rats.Photomedicine and Laser Surgery. 2006, 24(6), 735-740, 2006.

LIU, X. et al. Effect of lower-level laser therapy on rabbit tibial fracture. Photomed Laser Surg. 25:487-494, 2007.

LOW, J.; REED, A. Eletroterapia Explicada: Princípios e Prática. 3.ed São Paulo: Manole, 2001.

LUGER, E.J. et al. Effect of low-power laser irradiation on the mechanical properties of bone fracture healing in rats. Lasers Surg Med. 22: 97-102, 1998.

MACDONALD, H.M. et al. Changes in trabecular and cortical bone microarchitecture at peripheral sites associated with 18 months of teriparatide therapy in postmenopausal women with osteoporosis. Osteoporos Int, 22:357-362, 2011.

MANDELBROT, B.B. The Fractal Geometry of Nature. W. H. Freeman: New York, 1982.

MARINO, J.A.M. Efeito do laser terapêutico de baixa potência sobre o processo de regeneração óssea em tíbia de rato. Dissertação de Mestrado - Universidade Federal de São Carlos, São Carlos, 2003.

MARSELL, R.; EINHORN, T.A. Emerging Bone Healing Therapies. Journal of Orthopaedic Trauma. 24, S4-S8, 2010.

MARSELL, R.; EINHORN, T.A. The Biology of Fracture Healing. Injury.42, 6: 551-555, 2011.

MASON, T.J. Therapeutic ultrasound an overview. Ultrasonics Sonochemistry. 18:847852. DOI:10.1016/j.ultsonch.2011.01.004, 2011.

MASSON C.; DUNNIL P. A Brief Definition of Regenerative Medicine. Reg. Med. 3: 1-5, 2008.

MAYR, E.; FRANKEL, V.; RÜTER, A. Ultrasound an Alternative Healing Method for Nonunions? Arch Orthop Trauma Surg. 120: 1-8, 2000.

MAYR, E.; LAULE, A.; SUGER, G. et al. Radiographic Results of Callus Distraction Aided by Pulsed Low-Intensity Ultrasound. J Orthop Trauma. 15: 407-14, 2001.

MERLI, L.A.S. et al. The Low Level Laser Therapy Effect on the Remodeling of Bone Extracellular Matrix. Photochemistry and Photobiology, 88: 1293-1301, 2012.

METHOD NOTE - Bone mineral density (BMD) and tissue mineral density (TMD) calibration measurement by micro-CT using Bruker-MicroCT and CT-Analyzer, 2012.

MEYER U.; BÜCHTER; A. WIESMANN, H.P.; JOOS, U.; JONES, D.B. Basic reactions of osteoblasts on structured material surfaces. European Cells and Materials 9: 39-49, 2005. 
MILES, J.D. et al. Rat Tibial Osteotomy Model Providing a Range of Normal to Impaired Healing. Journal of Orthopaedic Research; 29: 109-115. doi:10.1002/jor.21194; 2011.

MILANETTI, M.R. Avaliação do Reparo Ósseo em Osteotomia Experimental por Microtomografia por Raio-X. Dissertação de mestrado. Programa de Pós-Graduação Interunidades em Bioengenharia da Universidade de São Paulo (USP). 2010. 60p.

MORAES, P.C. O uso do ultra-som pulsado de baixa intensidade em falhas ósseas produzidas experimentalmente em rádio de coelhos, preenchidas ou não com cimento de fosfato de cálcio. Tese. Faculdade de Ciências Agrárias e Veterinárias - UNESP, Jabuticabal, 2006.

MORGAN, E.F., MASON, Z.D., CHIEN, K.B., PFEIFFER, A.J., BARNES, G.L., EINHORN, T.A., GERSTENFELD, L.C. Micro-computed tomography assessment of fracture healing: relationships among callus structure, composition, and mechanical function. Bone.44, 2: 335-44, 2009.

MORPHOMETRIC PARAMETERS MEASURED BY SKYSCAN CT-ANALYSER SOFTWARE, Bruker, 2013.

NEWMAN, P.G.; ROZYCKI, G.S. The History of Ultrasound. Surgical Clinics of North America. 78, 2: 179-195, 1998.

NICOLAU, R.A. Effect of low-power GaAIAs laser $(660 \mathrm{~nm})$ on the bone structure and cell activity: an experimental animal study. Lasers Med Sci. 18, 2: 89-94, 2003.

NOLTE, P.A. et al. Low-Intensity Pulsed Ultrasound in the Treatment of Nonunions. J Trauma. 51:693-703, 2001.

ODGAARD A., GUNDERSEN J.G., Quantification of Connectivity in Cancellous Bone, with Special Emphasis on 3-D Reconstructions. Bone, 14, 1993.

OKADA, K. et al. Congenital pseudoarthrosis of the tibia treated with low-intensity pulsed ultrasound stimulation (LIPUS). Ultrasound in Med. \& Biol., 29, 7: 1061-1064. 2003.

OLIVEIRA, P. et al. Comparison of the effects of low-level laser therapy and lowintensity pulsed ultrasound on the process of bone repair in the rat tibia. Rev Bras Fisioter., 15, 3: 200-205, 2011.

PAOLILLO, F.R., MILAN J.C.; ANICETO, I.V., BARRETO, S.G., REBELATTO, J.R., BORGHI-SILVA, A., PARIZOTTO, N.A., KURACHI, C., BAGNATO, V.S. Effects of Infrared-Led Illumination Applied During High-Intensity Treadmill Training in Postmenopausal Women. Photomedicine and Laser Surgery. 29, 9:639-645. 2011.

PAOLILLO, F.R.; MILAN, J.C.; CORAZZA, A.V.; PAOLILLO, A.R.; BORGUI-SILVA, A.; PARIZOTTO, N.A.; KURACHI, C.; BAGNATO, V.S. Effects of Ledtherapy on Bone Mass During Aging. In: 1th Workshop Bone as Engineering Material. São Carlos. Proceedings of the Bone as Enginnering Material, Workshop, 2011b. 
PAPE H.C., GIANNOUDIS P.V., GRIMME K., VAN GRIENSVEN M., KRETTEK C. Effects of intramedullary femoral fracture fixation: what is the impact of experimental studies in regards to the clinical knowledge? Shock. 184: 291-300, 2002.

PAZZAGLIA, U. E. et al. Morphometric Analysis of the Canal System of Cortical Bone: An Experimental Study in the Rabbit Femur Carried Out with Standard Histology and Micro-CT. Anatomia, histologia, embryologia. 39: 17-26, 2010.

PEPLOW, P.V., CHUNG, T.Y., BAXTER, G.D. Laser Photobiomodulation of Wound Healing: A Review of Experimental Studies in Mouse and Rat Animal Models. Photomed Laser Surgery, 28, 291-325, 2010.

PERREN, S.M. Evolution of the internal fixation of long bone fractures. The scientific basis of biological internal fixation: choosing a new balance between stability and biology. Journal of Bone Joint Surgery B, 84, 8: 1093-110, 2002.

PINHEIRO, A.L.B.; GERBI, M.E.M.M. Photoengineering of Bone Repair Processes. Photomedicine and Laser Surgery. 24, 2: 169-178, 2006.

PIRES-OLIVEIRA, D.A. et al. Evaluation of low-level laser therapy of osteoblastic cells. Photomed Laser Surg. 26:401-404, 2008.

PILLA, A. et al. Non-Invasive Low-Intensity Pulsed Ultrasound Accelerates Bone Healing in the Rabbit. Journal Orthopaedic and Trauma. 4: 246-253, 1990.

PÖNTINEM, P.J. Laseracupuncture. In: Simunovic, Z. (Ed.). Lasers in medicine and dentistry: basic and up-to-date clinical application of low energy-level laser therapy LLLT. Croatia: Rijeka; Vitgraf. 455-475, 2000

POPPI, R.R. et al. Evaluation of the osteogenic effect of low-level laser therapy $(808 \mathrm{~nm}$ and $660 \mathrm{~nm}$ ) on bone defects induced in the femurs of female rats submitted to ovariectomy. Lasers Med Sci. 26, 4:515-22, 2011.

POUNDER, N.M.; HARRISON, A. J. Low Intensity Pulsed Ultrasound for Fracture Healing: A Review of the Clinical Evidence and the Associated Biological Mechanism of Action. Ultrasonics 48(4):330-8, 2008.

PRETEL, H.; LIZARELLI, R.F.Z.; RAMALHO, L.T.O. Effect of Low-Level Laser Therapy on Bone Repare: Histological Study in Rats. Lasers in Surgery and medicine. 39, 788-796, 2007.

QUEIROGA, A.S. et al. Evaluation of Bone Repair in the Femur of Rats Submitted to Laser Therapy in Different Wavelengths: An Image Segmentation Method of Analysis. Laser Physics. 18, 9, 1087-1091, 2008.

RENNÓ, A.C.M., MOURA, F.M., SANTOS, N.S.A., TIRICO, R.P., BOSSINI, P.S., PARIZOTTO, N.A.. The Effects of Infrared-830 nm Laser on Exercised Osteopenic Rats. Lasers Med. Sci. 21, 202-207, 2006.

1 De acordo com as normas da ABNT 6023 
RENNÓ, A.C.M. et al. The effects of laser irradiation on osteoblast and osteosarcoma cellproliferation and differentiation in vitro. Photomed Laser Surg. 25:275-280, 2007.

RENNÓ, A.C.M. et al. Ultrasound Therapy Modulates Osteocalcin Expression During Bone Repair in Rats. Ultrasonics. doi:10.1016/j.ultras.2011.07.002; 2011.

ROBLING, A.G., CASTILLO, A.B., AND TURNER, C.H. Biomechanical and molecular regulation of bone remodeling. Annu. Rev. Biomed. Eng. 8, 455-498, 2006.

ROQUE W.L., ARCARO K., BAYARRI A.A., Mechanical Competence of Bone: A New Parameter to Grade Trabecular Bone Fragility From Tortuosity and Elasticity, IEEE Transactions on Biomedical Engineering, 60 (5): 1363 - 1370, 2013.

ROSSIGNOL, D.A. et al. Indications and results for the ExogenTM ultrasound system in the management of non-union: A 59-case pilot study. Orthopaedics \& Traumatology: Surgery \& Research 98, 206-213, 2012.

RUBIN, C. et al. The Use of Low-Intensity Ultrasound to Accelerate the Healing of Fractures. Journal of Bone \& Joint Surgery. 83-A, 2: 259-270, 2001.

RUE, J.P. et al. The Effect of Pulsed Ultrasound in the Treatment of Tibial Stress Fractures. Orthopedics. 27(11): 1192-5, 2004.

RUNDUS, A.S.; HART, L.A. Overview: Animal Acoustic Communication and the Role of the Physical Environment. Journal of Comparative Psychology. 116, 2: 120-122, 2002.

RUTTEN, S. et al. Low-Intensity Pulsed Ultrasound Increases Bone Volume, Osteoid Thickness and Mineral Apposition Rate in the Area of Fracture Healing in Patients with a Delayed Union of the Osteotomized Fibula. Bone. 43, 2: 348-54, 2008.

SAHA, P.K.; GOMBERG, B.R.; WEHRLI, F.W.; Three-Dimensional Digital Topological Characterization of Cancellous Bone Architecture. Imaging Systems and Technology, 11 (1):81-90, 2000.

SALMON P.L. et al. Quantification for micro-CT of the architectural changes in bone and callus in a rat closed fracture healing model, Orthopaedic Research Society, Rosemont, Illinois, EUA, 2012.

SATO, W.; MATSUSHITA, T.; NAKAMURA, K. Acceleration of Increase in Bone Mineral Content by Low-I ntensity Ultrasound Energy in Leg Lengthening. Journal of Ultrasound in Medicine. 18 (10) 699-702, 1999.

SCHLICHER, R.K. et al. Mechanism of Intracellular Delivery By Acoustic Cavitation, Ultrasound in Med. \& Biol. 32, 6: 915-924, 2006.

SEYFARTH, R.M.; CHENEY, D.L. Signalers and Receivers in Animal Communication. Annu. Rev. Psychol. 54:145-73, 2003. 
SHAPIRO F. Bone development and its relation to fracture repair. the role of mesenchymal osteoblasts and surface osteoblasts. European Cells and Materials 15: 53-76, 2008.

SHIMIZU, N., et al. Low-Intensity Laser Irradiation Stimulates Bone Nodule Formation Via Insulin-Like Growth Factor-I Expression in Rat Calvarial Cells. Lasers Surg Med. 39(6), 551-559, 2007.

SILVA, A.M.H. Análise morfométrica 2D e 3D de amostras de osso trabecular utilizando microtomografia tridimensional por Raio-X. Dissertação (Mestrado). Programa de PósGraduação Interunidades Bioengenharia - USP (Escola de Engenharia de São Carlos, Faculdade de Medicina de Ribeirão Preto, Instituto de Química de São Carlos). São Carlos, 77p, 2009.

SILVA, M.A.M.; SILVA; G.J.S; CARDOSO, R.S. O Uso do Laser em Cirurgia Vascular. Revista Ciências em Saúde 3:1-8. 2011.

SIMMONS, C.A.; HIPP, J.A. Method-Based Differences in the Automated Analysis of the Three-Dimensional Morphology of Trabecular Bone. Journal of Bone and Mineral Research, 12: 942-947, 1997.

SISKA, P.A. et al. External Adjuncts to Enhance Fracture Healing: What is the Role of Ultrasound? Injury. 39.10: 1095-1105, 2008.

SKYSCAN (2010). BMD calibration from attenuation coefficient. Disponível na Internet: https://rcpt.yousendit.com/802028452/c6a564d80385b9751baab3f815f4b5ed >https://rcpt.you sendit.com/802028452/c6a564d80385b9751baab3f815f4b5ed. Acesso em fevereiro, 2010.

SKYSCAN. Morfometric parameters in CT-Analyser. In: Skyscan. The user's guide. Aartselaar, Bélgica, 2009.

SNYDER, B. M.; CONLEY, J.; KOVAL, K. J. Does Low-Intensity Pulsed Ultrasound Reduce Time to Fracture Healing? A Meta-Analysis. Am J Orthop.41, E12-19, 2012.

SON, J. et al. Bone Healing Effects of Diode Laser $(808 \mathrm{~nm})$ on a Rat Tibial Fracture Model. In Vivo. 26: 703-710, 2012.

STEIN, A. et al. Low-level laser irradiation promotes proliferation and differentiation of human osteoblasts in vitro. Photomed Laser Surg. 23, 2:161-6, 2005.

TAKIKAWA, T. Low-intensity pulsed ultrasound initiates bone healing in rat nonunion fracture model. J Ultrasound Med; 20:197-205, 2001.

TEITELBAUM, S.L.; ROSS, F.P. Genetic Regulation of Osteoclast Development and Function. Nature Reviews Genetics. 4, 8: 638-649, 2003.

TeITElBAuM, S.L. Osteoclasts: What Do They Do And How Do They Do It? The American Journal of Pathology. 170 (2): 427-435, 2007. 
TOBITA K. et al. Effect of low-intensity pulsed ultrasound stimulation on gap healing in a rabbit osteotomy model evaluated by quantitative micro-computed tomography-based cross-sectional moment of inertia. J Orthop Sci. 17:470-476, 2012.

TRELLES, M.; MAYAYO, E. Bone fracture consolidates faster with low power laser. Lasers Surg Med. 7, 36-45, 1987.

TSUMAKI, N. et al. Low-Intensity Pulsed Ultrasound Accelerates Maturation of Callus in Patients Treated with Opening-Wedge High Tibial Osteotomy by Hemicallotasis. J Bone Joint Surg. 86A: 2399-405, 2004.

URITA A. et al. Effect of Low-Intensity Pulsed Ultrasound on Bone Healing at Osteotomy Sites After Forearm Bone Shortening.J Hand Surg, 38A:498-503, 2013.

VLADIMIROV, Y.A., OSIPOV, A.N., KLEBANOV, G.I. Photobiological Principles of Therapeutic Applications of Laser Radiation. Biochemistry (Moscow). 69, 81-90, 2004.

VINCK, E. et al. Evidence of Changes in Sural Nerve Conduction Mediated By Light Emitting Diode Irradiation. Lasers Med. Sci. 20, 35-40, 2005.

XAVIER, C.A.M.; DUARTE, L.R. Estimulação Ultra-Sônica Do Calo Ósseo: Aplicação Clínica. Revista Brasileira de Ortopedia, v.18, n.3, p.73-80, 1983.

Wang, Y.; Chai, W.; Wang, Z.-G.; Zhou, Y.-G.; Zhang, G.-Q.; Chen, J.-Y. Superelastic cage implantation. A new technique for treating osteoncrosis of the femoral head with middle-term follow-ups. J. Arthroplast. 2009, in press, doi: 10.1016/j.arth.2008.07.010.

WANG, S. et al. Low-Intensity Ultrasound Treatment Increases Strength in a Rat Femoral Fracture Model. Journal of Orthopaedic Research. 12, 1: 40-47, 1994.

WANG, P.; WANG, H.W.; STUREK, M.; CHENG, J.X. Bond-selective imaging of deep tissue through the optical window between 1600 and $1850 \mathrm{~nm}$. J. Biophotonics.; 5, 25-32, 2012.

WATANABE Y. et al. Three key factors affecting treatment results of low-intensity pulsed ultrasound for delayed unions and nonunions: instability, gap size, and atrophic nonunion. J Orthop Sci 18:803-810, 2013.

WOO, J. History of Ultrasound in Obstetrics and Gynecology, Part 1. Last revised March, 2006. Capturado na Internet em http://www.ob-ultrasound.net/history1.html. Disponível na Internet: 20 set 2012 .

WELLS, P.N.T. Velocity, Absorption and Attenuation in Biological Materials, In: Biomedical Ultrasonics, London, Academic Press, Cap. 4, p. 110-137, 1977.

ZISKIN, M.C. Report on safety of the therasonics medical systems (Exogen. Inc.), SAFHS Unit, model 2ª PMA P900009, v.3, VI. A, p.11, 1989. 
ZISKIN, M.C., LEWIN P.A. Physics of Ultrasound. In: Ultrasonic Exposimetry, Boca Ranton, Academic Press, Cap. 1, p. 37, 1993. 
ANEXOS 


\section{ANEXO A}

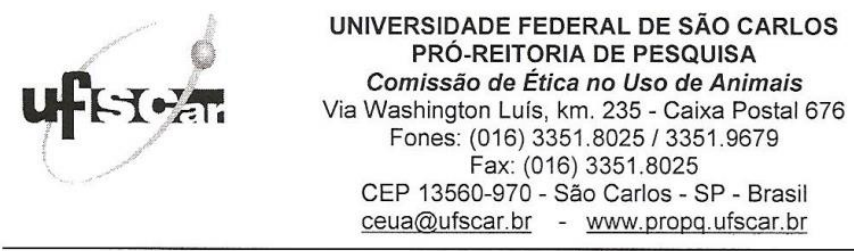

Parecer da Comissão de Ética no Uso de Animais

$n^{\circ} 057 / 2011$

Protocolo nº. 050/2011

A Comissão de Ética no Uso de Animais da Universidade Federal de São Carlos - CEUA/UFSCar APROVOU o projeto de pesquisa intitulado "Efeitos da associação de fototerapia e ultrasom de baixa intendidade no reparo de fratura óssea em tíbia de rato " submetido pela pesquisadora Alessandra Rossi Paolilo.

São Carlos, 15 de dezembro de 2011.

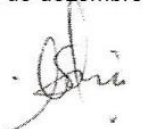

Profa. Dra. Luciana Thie Seki Dias

Presidente da Comissão de Ética no Uso de Animais 